\title{
The development of the Dangerous Grounds and Palawan Island in the southeastern part of the South China Sea, deduced from carbonate formations.
}

\author{
Dissertation \\ for the award of the degree \\ "Doctor rerum naturalium" (Dr.rer.nat.) \\ (alternatively: "Doctor of Philosophy" Ph.D. Division of Mathematics and Natural Sciences) \\ of the Georg-August-Universität Göttingen \\ within the doctoral program Geoscience \\ of the Georg-August University School of Science (GAUSS)
}

submitted by

Stephan Steuer

from Weingarten (Ravensburg)

Göttingen, 2018 
Thesis Committee

Prof. Dr. Jonas Kley / Abteilung Strukturgeologie und Geodynamik / Uni Göttingen

(Name of Department / Research Group, Institution)

Dr. Dieter Fanke / Fachbereich Geologie der Energierohstoffe / BGR

(Name of Department / Research Group, Institution)

Prof. Dr. Manuel Pubellier / Centre National de la Recherche Scientifique

(Name of Department / Research Group, Institution)

\section{Members of the Examination Board}

Reviewer: Prof. Dr. Jonas Kley / Abteilung Strukturgeologie und Geodynamik / Uni Göttingen

(Name of Department / Research Group, Institution)

Second Reviewer: Dr. Dieter Fanke / Fachbereich Geologie der Energierohstoffe / BGR

(Name of Department / Research Group, Institution)

Additional Reviewer (if applicable): Prof. Dr. Manuel Pubellier / Centre National de la Recherche Scientifique (Name of Department / Research Group, Institution)

Further members of the Examination Board:

Prof. Dr. Hilmar von Eynatten / Sedimentologie/Umweltgeologie / Uni Göttingen

(Name of Department / Research Group, Institution)

Dr. David Hindle / Strukturgeologie und Geodynamik / Uni Göttingen

(Name of Department / Research Group, Institution)

(Name of Department / Research Group, Institution)

(Name of Department / Research Group, Institution)

Date of the oral examiniation: 01. February 2019 


\section{GEORG-AUGUST-UNIVERSITÄT GÖTTINGEN}

The development of the Dangerous Grounds and Palawan Island in the southeastern part of the South China Sea, deduced from carbonate formations.

Dissertation zur Erlangung des Doktorgrades der Georg-August-Universität Göttingen

Vorgelegt von

Stephan Steuer 
This investigation was conducted as part of a cooperative research group consisting of:

Bundesanstalt für Geowissenschaften und Rohstoffe BGR (Hannover, Germany)

Ecole Normale Supérieur ENS (Paris, France)

University of the Philippines UP (Manila, Philippines)

TOTAL (Paris, France)

Funded by TOTAL (Paris, France) 
Hiermit erkläre ich an Eides statt, dass die vorliegende Abhandlung, abgesehen der ausgewiesenen Zitate, nach Inhalt und Form meine eigene Arbeit darstellt. Ferner habe ich weder diese noch eine ähnliche Arbeit an einer anderen Abteilung oder Hochschule im Rahmen eines Prüfungsverfahrens vorgelegt.

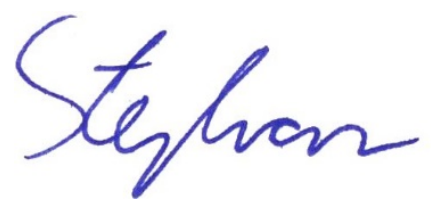

Stephan Steuer

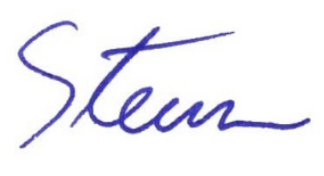




\section{Acknowledgements:}

I would like to express my great gratitude to Professor Dr. Jonas Kley for the opportunity to do this dissertation. Further I'd like to thank Professor Manuel Pubellier (ENS) and Dr. Dieter Franke (BGR) for the supervision of this thesis. Also I like to thank Dr. Heidrun Stück for proof-reading this thesis.

I'd also like to thank Professor Mario Aurelio (UP) for his support during the field work (2010) and an inspiring field trip (2014) on Palawan Island.

A huge "Dankeschön” is going to my wife Cordula for her sympathy and loving support during the writing of this thesis. Thank you for your patience and your willingness to spend your life with a Geologist.

A special thank you is going to all the colleagues who accompanied me during the field work on Palawan Island as they are: Prof. Dr. Manuel Pubellier, Prof. Dr. Mario Aurelio, Dr. Florian Meresse, Dr. Dimitri Savva, Dr. Dieter Franke, Kristine Taguiabao and Coleen Carranza. Thank you for the great collaboration, inspiring discussions and legendary evenings.

I like to thank TOTAL in Paris, especially Jean-Luc Auxietre and Benoit Mouly for the organization and funding of this research group.

Finally, I like to thank all the people who inspired me. Thank you for all the good discussions on conferences and workshops.

Thank you, Danke, Merci, Salamat. 
I like to dedicate this thesis to my lovely daughter Marlene.

A constant source of joy and distraction (from writing this thesis). 


\section{Disclaimer}

The main part of this thesis consists of two papers which are published in the "Journal of Asian Earth Sciences" (2013) and in "Marine and Petroleum Geology” (2014). To increase the internal logic order of the thesis, the two publications were not placed according to their date of publication within the thesis.

Every article is based on research I did in the previous time. As part of a research group I profited on a vivid exchange of knowledge and ideas which is hard to quantify. But since my colleagues were working in other areas of the South China Sea I can state that I developed my own ideas and the publications represent my own original work.

In the first (2013) paper (Chapter 4) the chapter “Geological setting” was done in close collaboration with my co-author Dr. Dieter Franke. The rest of the text and the figures represent completely my own work. Dr. Florian Meresse and Prof. Dr. Manuel Pubellier helped by proof-reading the manuscript and Prof. Dr. Mario Aurelio provided additional data on the onshore geology of southern Palawan. Jean-Luc Auxietre was the coordinator of the project.

In numbers: $85 \%$ of this publication represents completely my own work, $10 \%$ were contributed by my coauthor Dr. Dieter Franke and the other co-authors together contributed 5\% to the text.

The second (2014) paper (Chapter 3) represents almost completely my own work. During the proof-reading helpful comments on the structure of the article were given by Dr. Dieter Franke. Again, all figures were created by myself.

In numbers: 95\% of this publication represents my own work and Dieter Franke contributed 5\% to the text. Since it was published at the very end of the project, I got no help or feedback from my French colleagues. Within the research group a second PhD-thesis was conducted by Dimitri Savva. This thesis was focusing on the onshore areas in south China and onshore Palawan Island. We exchanged ideas to seamlessly connect our research work onshore and offshore. 


\section{Preface}

Since the main part of this thesis consists of two published articles, the two corresponding chapters are almost exact copies of these articles. To increase the readability of the whole text the numbering of the figures was changed to fit the main thesis. Also the list of references was removed from each article. The reference list at the end of the thesis comprises the references of the articles as well as the rest of the text. Whenever possibly I used the colored figures (published in the online version of the articles) instead of the black-and-white figures from the printed version of the articles. Due to a software problem some figures from the first paper (Chapter 4) were lost and had to be re-created. The layout of these figures may differ slightly from the originally published, but the content and message of them is the same.

The chapter about the tectonic evolution of the South China Sea was also used, in a slightly modified version, for the final report of the GRI project. Similar versions of this text are also used within publications Dr. Dieter Franke or I (co-)authored, e.g. (Barckhausen et al., 2014; Franke et al., 2014). The final report was distributed among the participants of the GRI-project but not published. 


\section{Main questions to be addressed in this thesis:}

In 2010 TOTAL initiated a research group to further investigate the hydrocarbon potential of the deepwater parts of the South China Sea. This region stands exemplarily for passive non-volcanic continental shelfs, which were actively deformed. At the beginning of this research project a series of questions rose. The most important questions to be tackled are given in the following. The chapter of this thesis in which the way to the answers is explained is given in brackets.

- How did the southeastern margin of the South China Sea evolve over time? The special focus is laid on the post-breakup development and the collision of that area with a thrusted wedge. (Chapter 4)

- Is it possible to find a way of constraining the post-rift development? When did the margin collide and how was this affecting the continental crust? (Chapter 3)

- Is it possible to find the continent-ocean boundary of the proto-South China Sea?

- How are the carbonates offshore western Palawan distributed? What are the constraints of their development and is it possible to link the development with regional tectonics? (Chapter 3)

- Is it possible to correlate the various published and interpreted unconfomities over the Dangerous Grounds? (Chapter 3) 


\section{Schematic flowchart of the development of this thesis}

The following image was developed to illustrate the way I went from the raw data to the scientific discoveries described in the different chapters. Also it illustrates how the different chapters and conducted tasks depend on each other and are following each other.

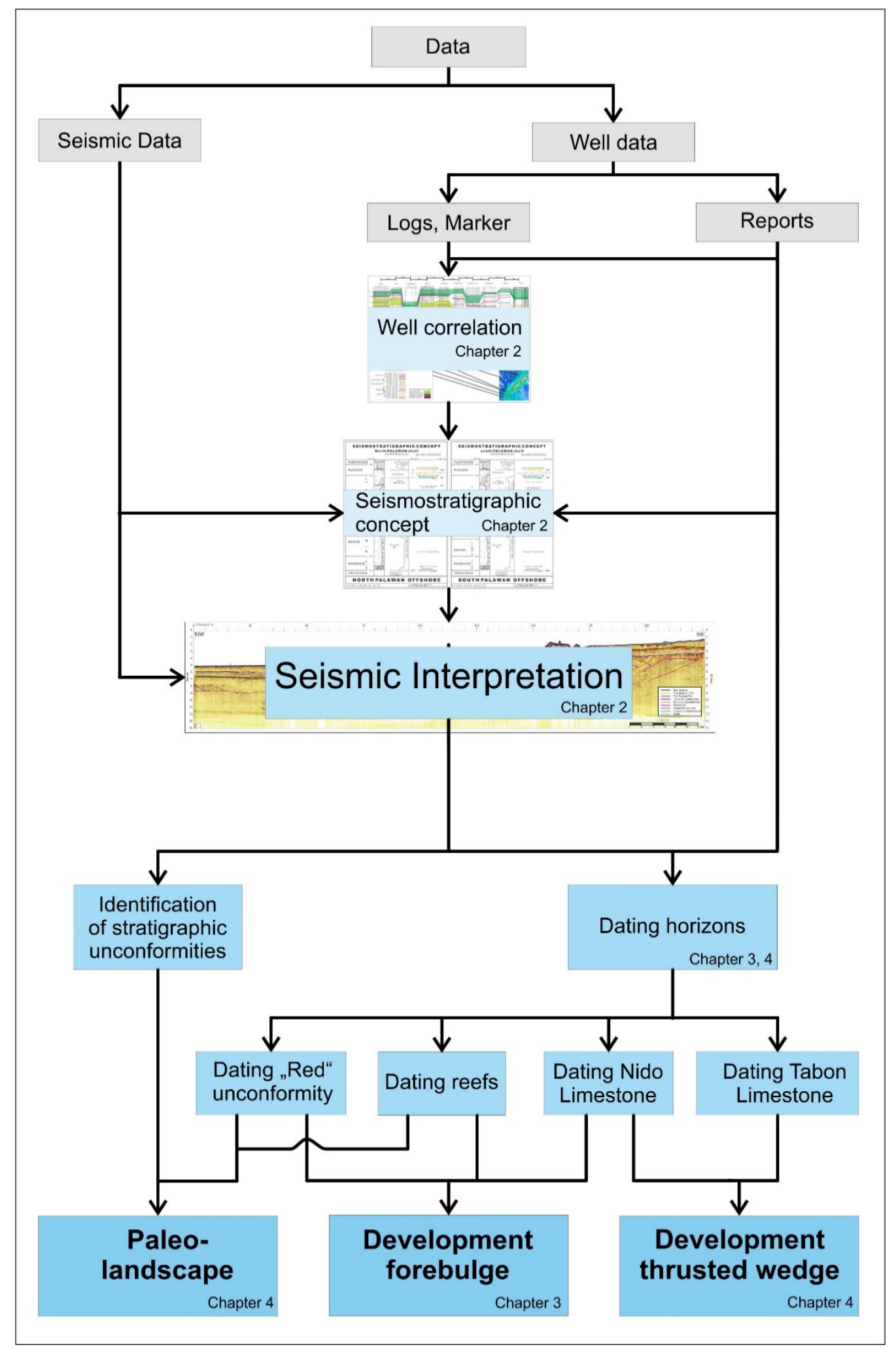




\section{Abstract}

The South China Sea is a quite narrow Cenozoic ocean basin. It is located between China in the north, Vietnam in the west, Malaysia and Brunei in the southeast and the Philippines in the north and northeast. Rifting in the South China Sea initiated in the late Cretaceous and the extension, including the spreading, prevailed until the Miocene. The post-rift development of the southwestern part of the South China Sea, the Dangerous Grounds, especially their collision with Palawan and Borneo can be deduced from the investigation of Oligocene to Pliocene limestone formations. Of special interest in that area is the Oligocene-Miocene "Nido" limestone. This limestone forms a widespread carbonate platform offshore WPalawan, Borneo and in the easternmost parts of the Dangerous Grounds. From seismic images it is clearly visible that this carbonate platform seals most of the extensional tectonics in the Dangerous Grounds. Towards the southeast this carbonate platform dips downward and is overthrusted by the thrust wedges of Borneo and southern Palawan. Offshore northern Palawan the Nido limestone has not been overthrusted and it dips gently towards the west. The division line between these two occurrences can be drawn across Ulugan Bay in the middle of Palawan Island. By analyzing the ages of this carbonates using biostratigraphic reports by Robertson Research the age for the top of the carbonate platform was assigned to $19 \mathrm{Ma}$, even though some of the reefs, growing on top of the platform continued to develop in some places up to recent times.

A second limestone developed on top of the thrusted wedge offshore SW-Palawan. This limestone formation was named “Tabon Limestone”. Since it is only slightly affected by the thrust tectonics, it is used to constrain the final phase of collision between the Dangerous Grounds and Palawan. The base and top of this limestone were investigated similar to the Nido and revealed a strong time- and space- transgressive nature. The age for the base of the carbonates ranges between 16 and $7 \mathrm{Ma}$, depending on the sampling point. There is a clearly recognizable younging trend towards the west. This led to the idea that the development of the limestone was strongly affected by the development of the wedge and that it is possible to use this limestone to date that development. While seafloor spreading is assumed to have ceased at 20.5 Ma (Barckhausen et al., 2014; Barckhausen and Roeser, 2004) the convergence in the Palawan area continued until around 5-7 Ma. A last uplifting event in the Pleistocene brought parts of southern Palawan above the sea level and exposed the Tabon limestone. Carbonate precipitates found on a marine bivalve in a cave near Quezon in the southern part of Palawan Island give indications to a working spleothem at 1.2 Ma (Rehm, 2002).

The following thesis presents the results of the investigation in the Dangerous Grounds and Palawan area, including the Reed Bank Block, as they were published in two papers: "Time constraints on the evolution of southern Palawan Island, Philippines from onshore and offshore correlation of Miocene limestones”, Journal of Asian Earth Sciences 2013 and “Oligocene-Miocene carbonates and their role for constraining the rifting and collision history of the Dangerous Grounds, South China Sea” Marine and Petroleum Geology 2014. 


\section{Content}

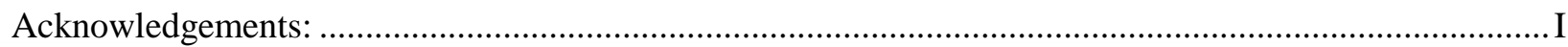

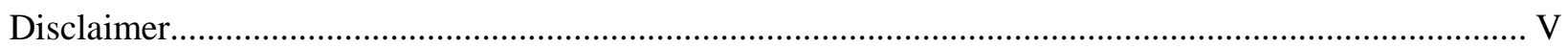

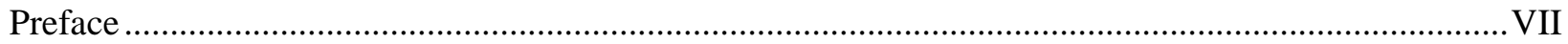

Main questions to be addressed in this thesis: ...................................................................................... IX

Schematic flowchart of the development of this thesis ........................................................................... XI

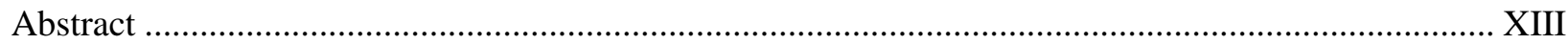

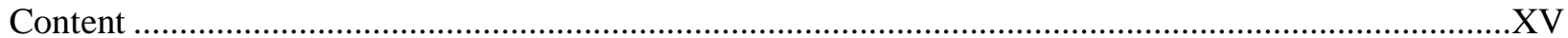

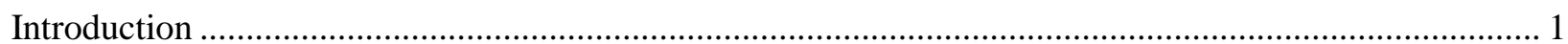

The Groupe Recherché Industrie (GRI) ………….......................................................................... 3

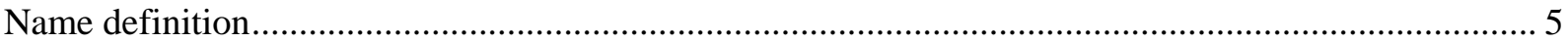

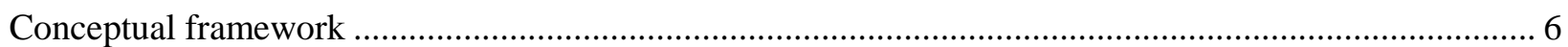

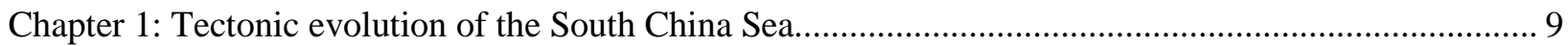

Rifting and the origin of extension in the South China Sea ................................................................ 9

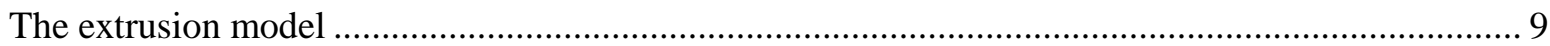

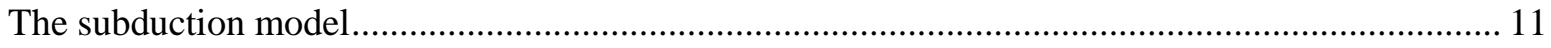

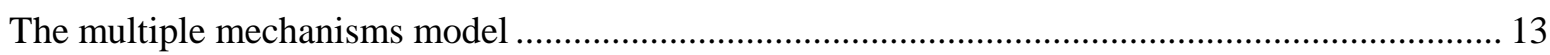

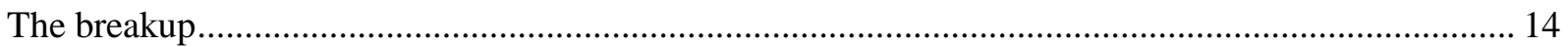

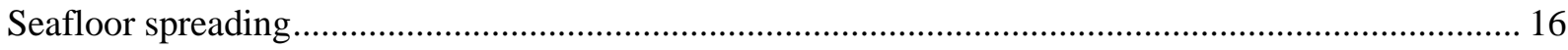

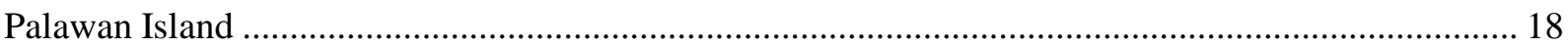

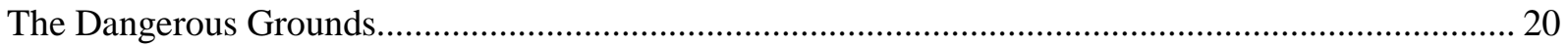

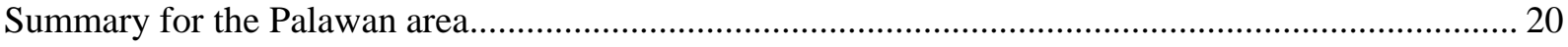

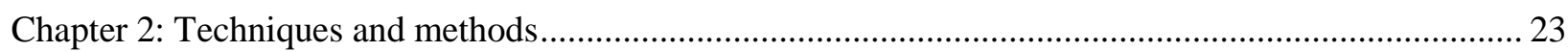

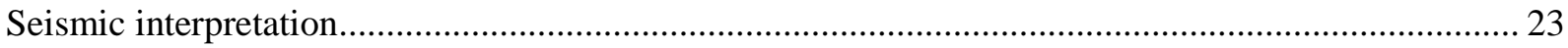

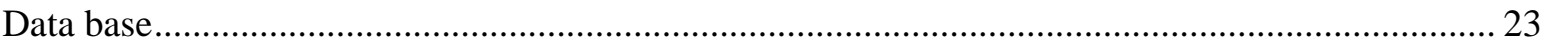

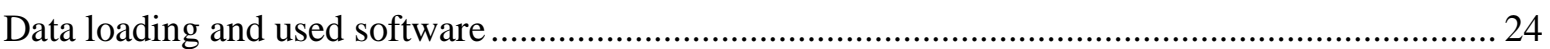

Seismostratigraphic concept and Interpreted horizons .................................................................... 24

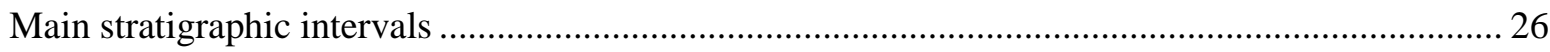

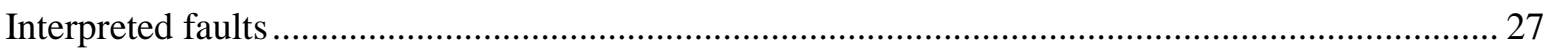




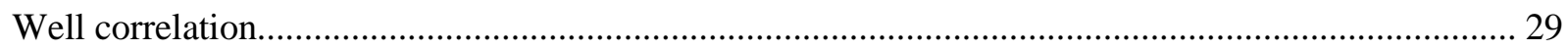

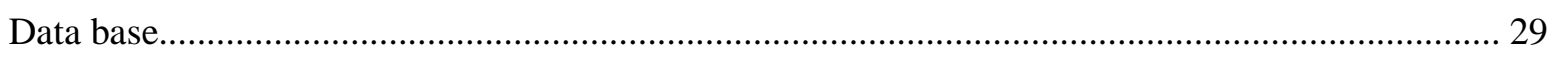

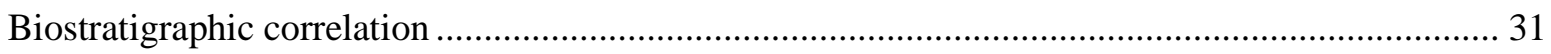

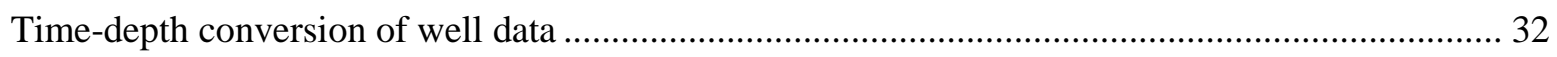

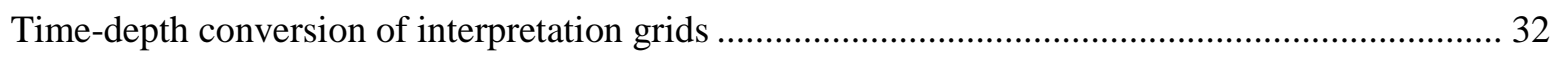

Chapter 3: Oligocene-Miocene carbonates and their role for constraining the rifting and collision history

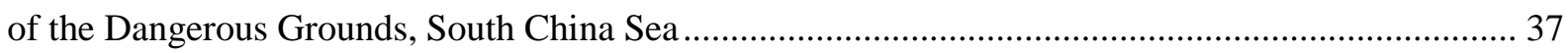

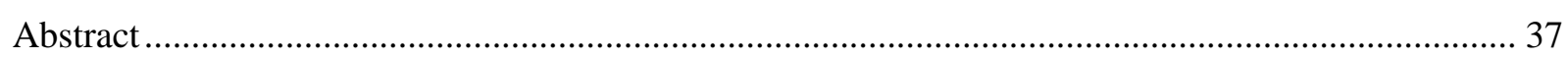

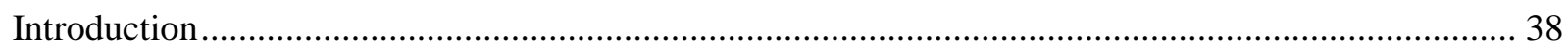

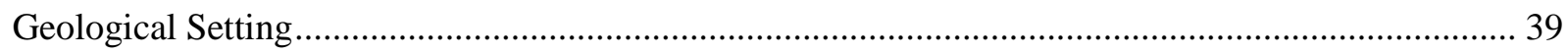

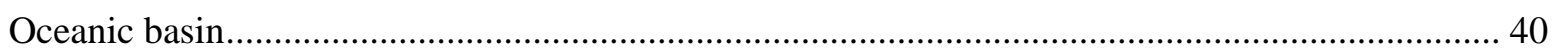

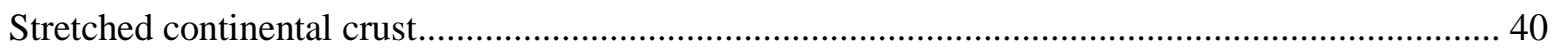

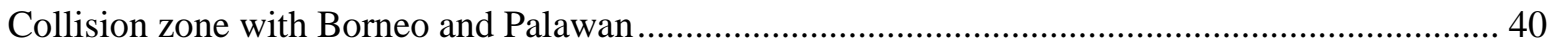

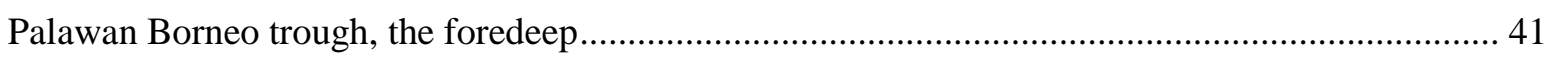

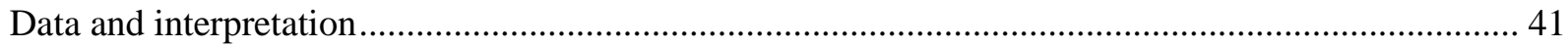

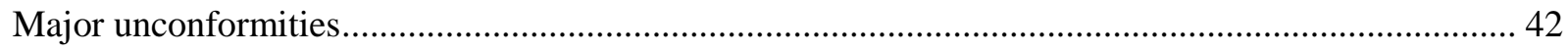

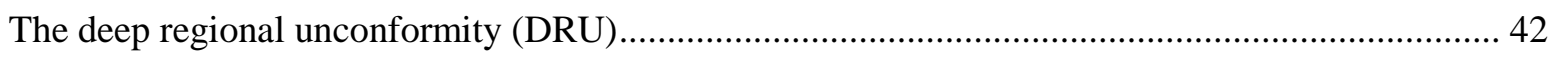

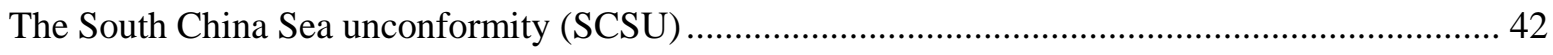

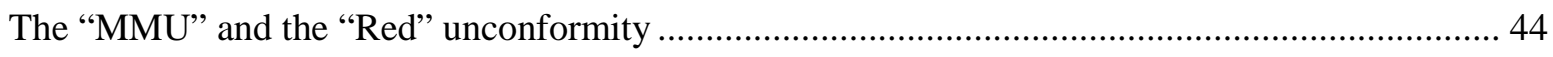

Correlation between Red Unconformity and the breakup unconformity......................................... 44

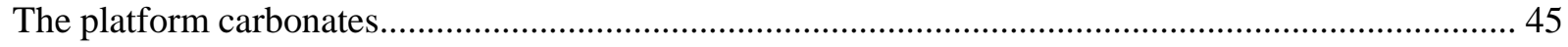

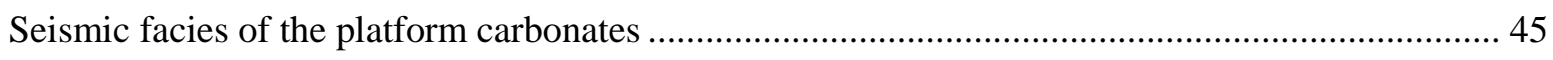

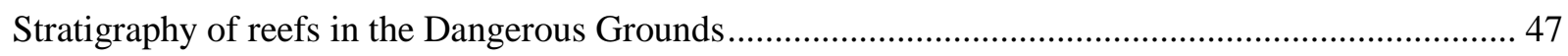

Tectonic evolution of the Reed Bank Block ..................................................................................... 52

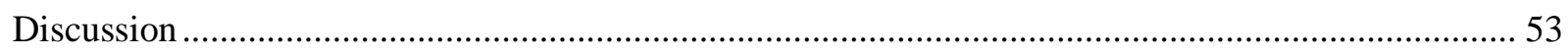

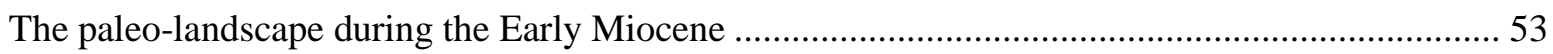

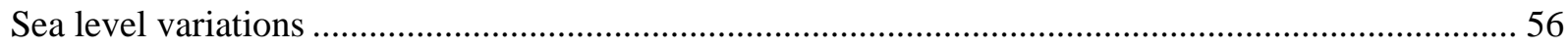

Post Middle Miocene development …................................................................................... 56

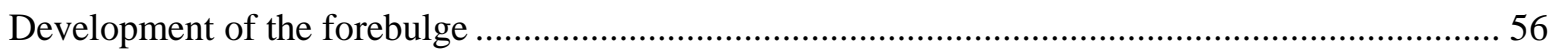


Acknowledgments

Chapter 4: Time constraints on the evolution of Southern Palawan Island, Philippines from onshore and offshore correlation of Miocene Limestones (Journal of Asian Earth Sciences, 2013)..... 61

Abstract 61

Introduction 62

Geological Setting

Northern Palawan

Central and southern Palawan.

Data base 70

Interpretation 71

Oligocene to Early Miocene platform carbonates, the Nido carbonates. 71

Age and stratigraphy of Tabon limestone 75

Discussion 81

Nido limestone. 81

Relationship between the Nido, Tabon, and Pulute Formations 82

Time constraints for the initiation of wedge development 83

Uplift of southern and central Palawan Island 84

Uplift of northern Central Palawan..................................................................................... 85

Conclusions 86

Acknowledgments 86

Erratum. 86

Chapter 5: Discussion.

How did the southeastern margin of the South China Sea evolve during time? ......

Is it possible to find a way of constraining the post-rift development? When did the margin collide and how was this affecting the continental crust?

Is it possible to find the continent-ocean boundary of a proposed proto-South China Sea?.....

How are the carbonates offshore western Palawan distributed? What are the constraints of their development and is it possible to link the development with regional tectonics?......

Is it possible to correlate the various published and interpreted stratigraphic unconfomities? 


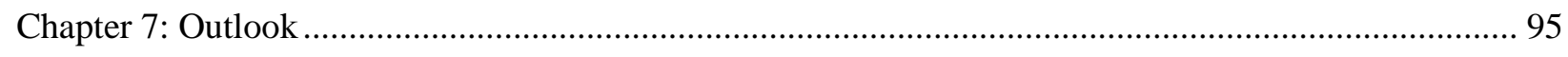

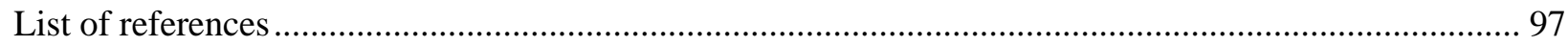

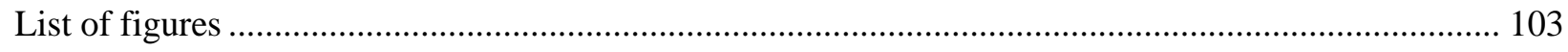

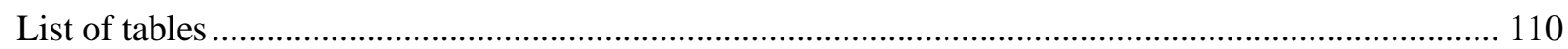

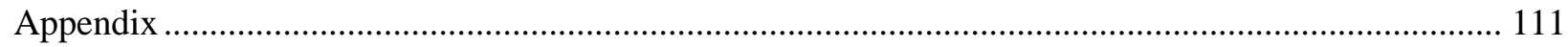




\section{Introduction}

The South China Sea is a rather small, Cenozoic oceanic basin, located between China in the north, Vietnam in the west, the Philippines in the east (and south) and Brunei and Malaysia in the south. It covers approximately 3,685,000 $\mathrm{km}^{2}$ and offers wide shelf areas with rifted continental crust underneath (in the north and south), an oceanic part with extinct spreading centers (in the middle) and an active subduction zone in the east.

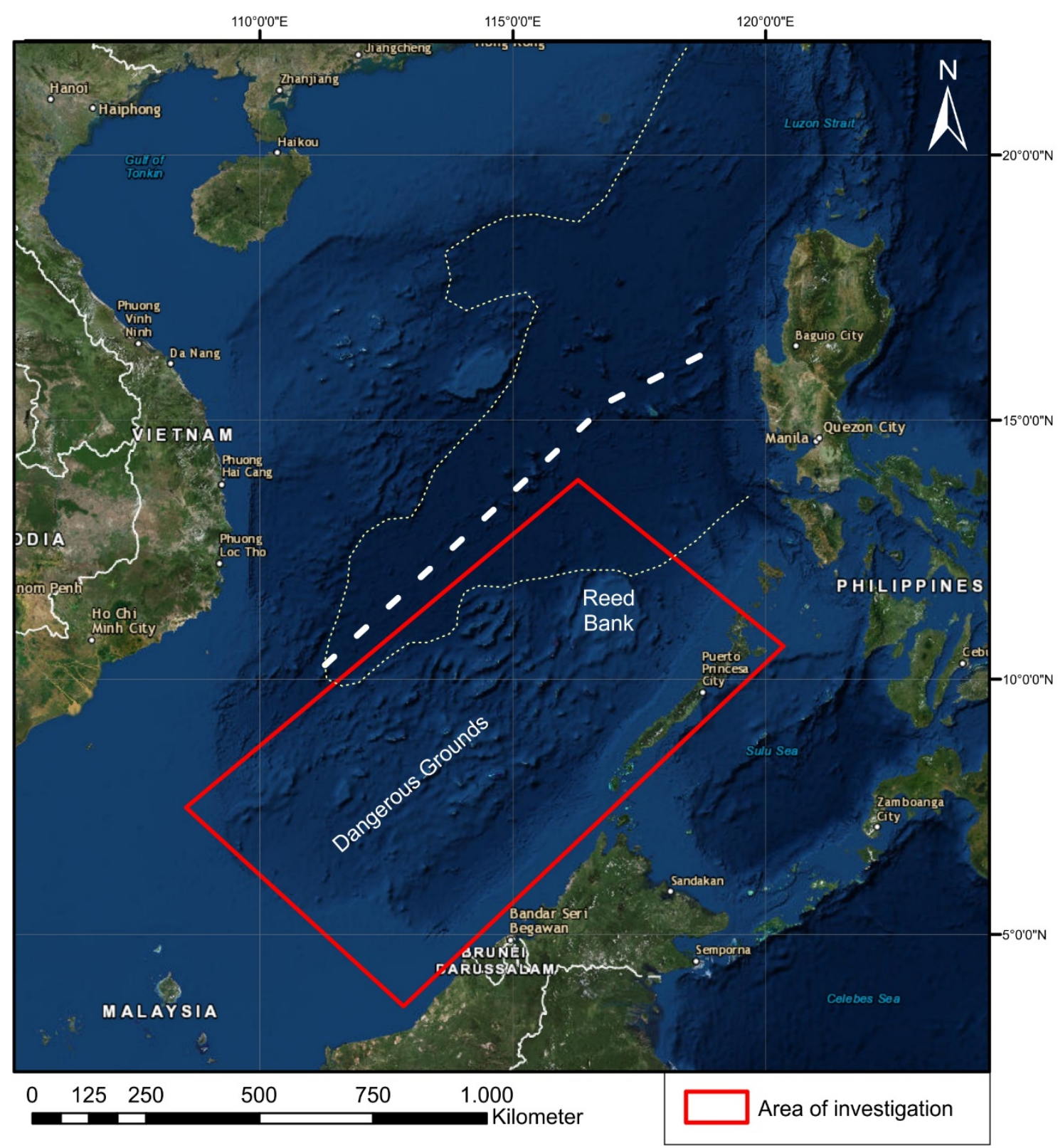

Figure 1: Satellite image of the South China Sea. The approximate outline of the investigation area is marked by a red rectangle. The thin yellow dotted line represents the approximate outline of the oceanic part of the South China Sea while the dashed white line marks the approximate position of the old mid oceanic ridge.

Figure 1 shows a satellite image of the whole South China Sea. The approximate working area is marked by a red rectangle. It comprises the Reed Bank Block, the Dangerous Grounds, the Palawan- 
Borneo trough and Palawan Island. For locations see figure 3. Also the position of the spreading ridge and the outline of the oceanic basin are indicated.

The geological map (highlighted part matches the red rectangle in figure. 1) of the South China Sea (figure. 2, (Pubellier, 2016)) shows highly stretched continental crust, covered by Miocene to Quaternary sediments in the area of the Dangerous Grounds. Also the occurrence of Miocene to recent reefs is indicated. The position and age of these reefs are one of my contributions to this map. It shows the investigation area with the Oceanic Basin at the top, the Dangerous Grounds in the center and the island of Palawan in the right part of the map. Areas outside the main area of interest are shaded. The full map is given in the appendix.

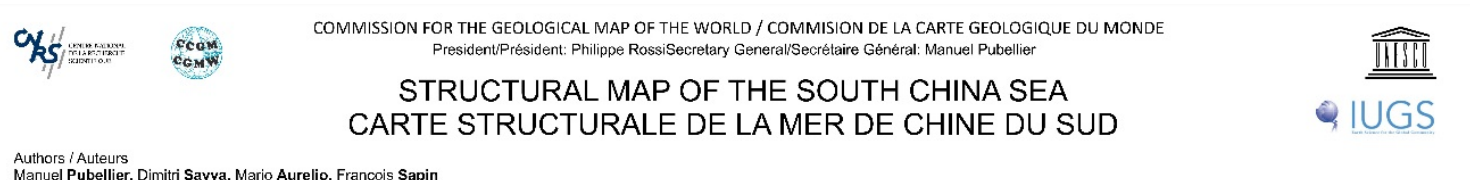

Authors / Auteurs Manuel Pubellier, Dimitri Savva, Mario Aurelio, Francois Sapin

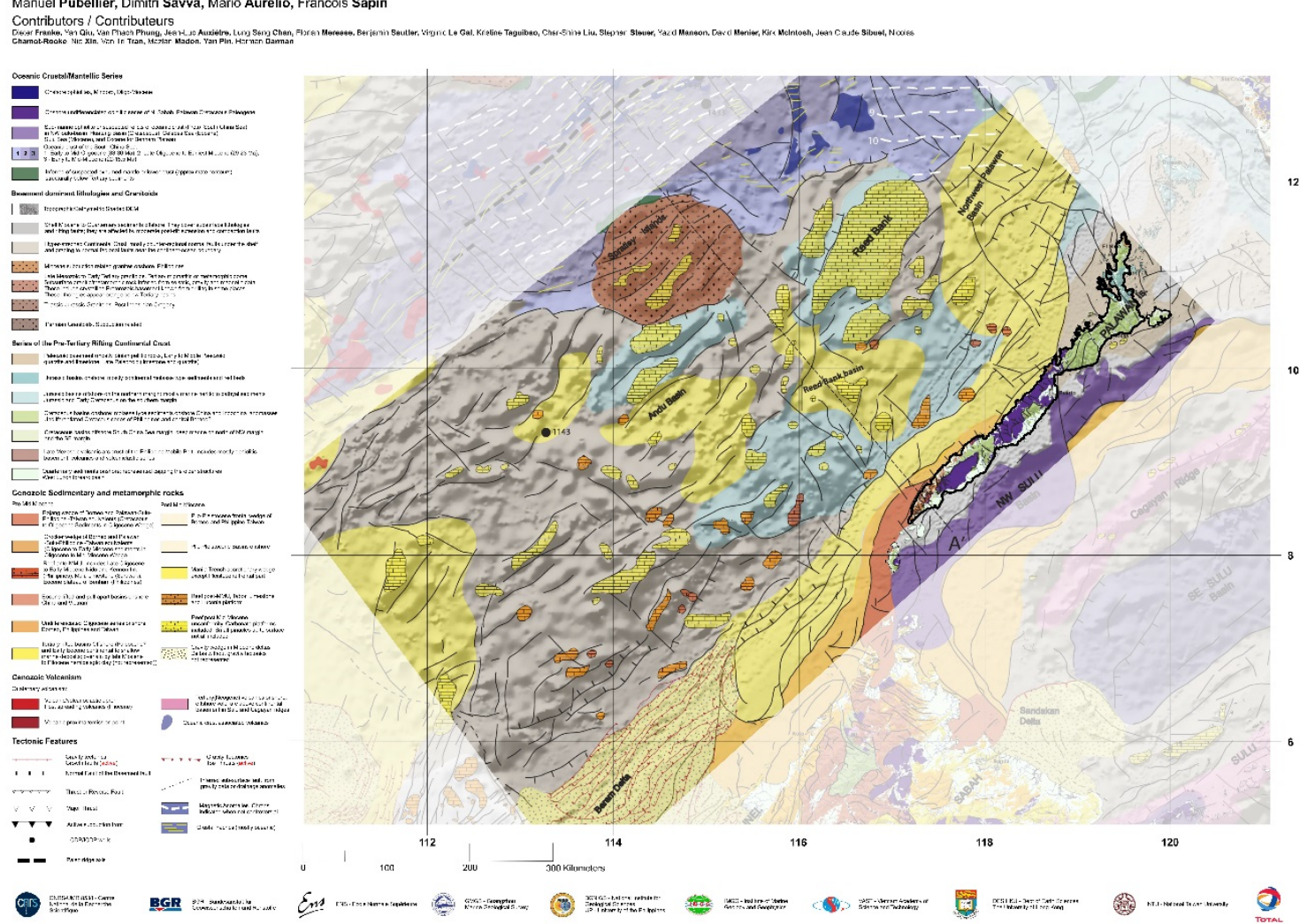

Figure 2: Detail of the Structural Map of the South China Sea redrawn after Pubellier et al. (2016). Areas outside the main area of interest are shaded. The whole map showing the island of Palawan (coastline of the main island highlighted) in the right and the Dangerous Grounds in the central part. The oceanic basin of the South China Sea is visible in the upper part of the map and the Island of Borneo in the lower central part.

Because of its relative young age, the South China Sea is well suited for investigations on the opening history and the mechanism of rifting and drift. Especially in the Dangerous Grounds in the southwestern part of the South China Sea, the structure of the rifted and tilted blocks (footwall of half-graben) is still visible in the bathymetry (Figure 1). During the last 30 years BGR has been conducting research in that area. This research comprised the acquisition of seismic data (Figure 
14) during several cruises (listed in appendix), dredged samples (Kudrass et al., 1986) and the compilation of well data, provided by the Philippine department of Energy (DoE).

\section{The Groupe Recherché Industrie (GRI)}

To gain a better understanding for the opening history of the South China Sea an international research group was initiated by TOTAL, the Bundesanstalt für Geowissenschaften und Rohstoffe (BGR) and the Ecole Normale Supérieur (ENS). This group connected academic researchers from France, Germany and the Philippines with the oil and gas industry and benefitted highly from the mutually access of data and the good exchange of knowledge between the group members.

Within this group different researchers focused on several areas within the South China Sea. One $\mathrm{PhD}$ thesis (by Dimitri Savva) focused mainly on the northern margin (mainland China), one postdoc (Dr. Florian Meresse) worked on the southwestern margin and this work is focused on the Dangerous Grounds and Palawan Island in the southeastern part of the South China Sea.

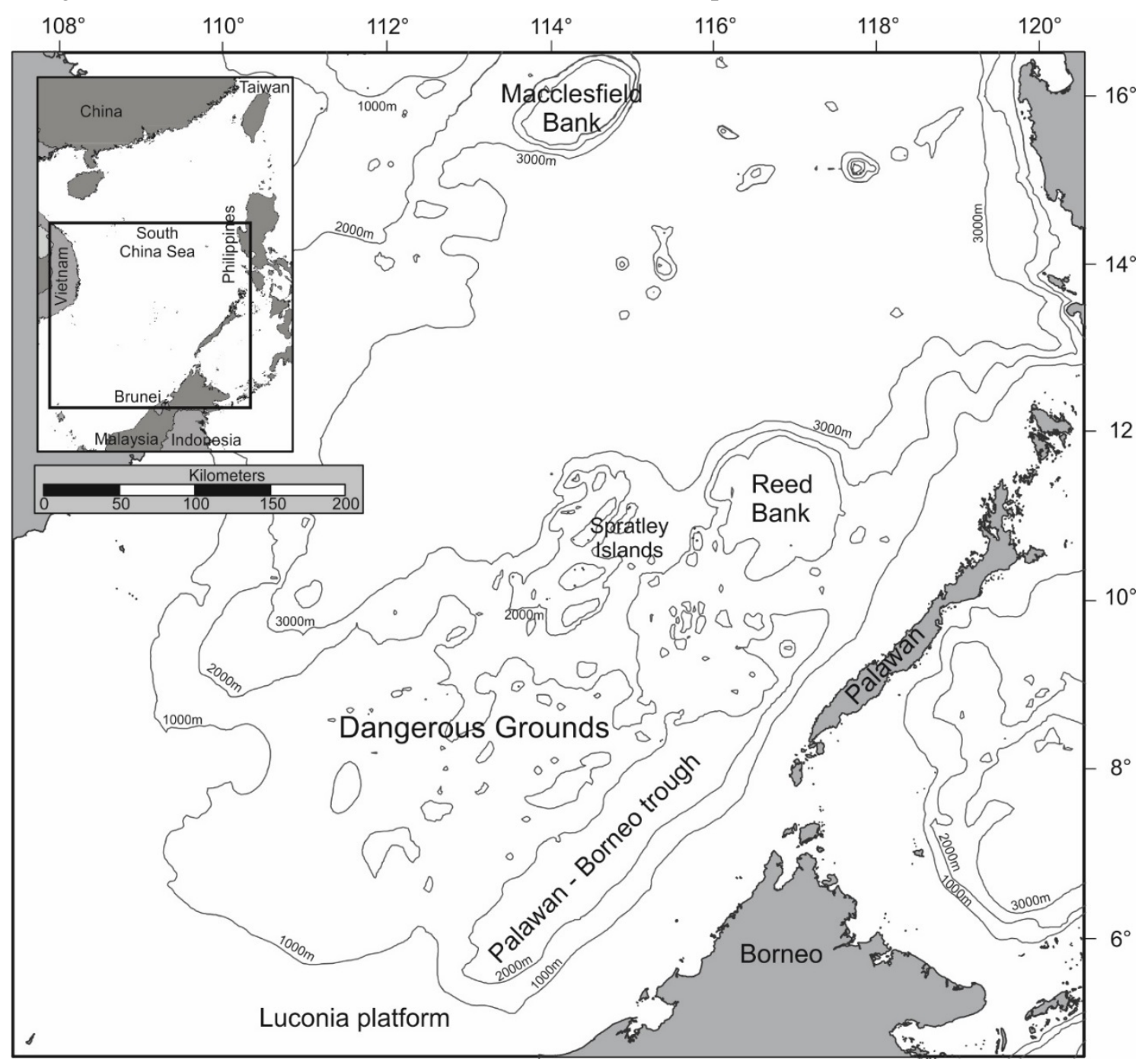

Figure 3: Overview map of the investigation area. The area of interest comprises the Reed Bank, Spratley islands, the Dangerous Grounds and the Palawan - Borneo trough. In the offshore areas the 1000m depth contours are shown. 
Introduction

The research group was coordinated by Prof. Dr. Manuel Pubellier (ENS) and Dr. Dieter Franke (BGR). Responsible for data access and funding was at first Benoit Mouly and in the second half of the project Jean-Luc Auxietre (both TOTAL). The field work onshore Palawan Island was supported by Dr. Mario Aurelio and two students from the National Institute for Geologic Sciences (NIGS) of the University of the Philippines (UP).

The outcomes of the GRI were presented at various international conferences and workshops and are also published in peer-reviewed journals e.g. a special volume of Marine and Petroleum Geology (JMPG, 2014). Even though every member focused on different aspects, there was a vivid exchange of ideas between the GRI members and therefore it was customary to put every member of the GRI on the list of co-authors. 


\section{Name definition}

Some confusion exists on the names of special regions or features within the study area. Depending on the origin of a researcher different names were assigned to the same region or feature. Especially names in publications by Chinese authors differ from the names given by other researchers.

Here a short overview of different names is presented. In this thesis the most common names (mostly used in publications) are used (given in the first column).

\begin{tabular}{|l|l|}
\hline Name used in this text: & a.k.a: \\
\hline South China Sea & West Philippine Sea (DoE website) \\
\hline Reed Bank & $\begin{array}{l}\text { Recto Bank (DoE website) } \\
\text { Liyue Bank e.g. (Wu, 1994) }\end{array}$ \\
\hline Palawan-Borneo Trough & Nansha trough e.g. (Ding and Li, 2011; Wu, 1994) \\
\hline Spratley Islands & Nansha Islands e.g. (Liu et al., 2004) \\
\hline $\begin{array}{l}\text { Dangerous Grounds } \\
\text { Table 1: Overview of regional names used in this thesis and in international publications. DoE: Department of energy } \\
\text { (www.doe.gov.ph). }\end{array}$ & Nansha Region e.g. (Ding and Li, 2011) \\
\hline
\end{tabular}

Another general naming problem exists in the term "unconformity". At least two different definitions of this term are in use. First, the sedimentologic / stratigraphic definition, meaning an erosional (non-depositional) event resulting in a hiatus in the stratigraphic record. This can be a conformal hiatus or an angular unconformity.

The second definition is from a geophysical point of view. Changes in the acoustic impedance of a subsurface material (mostly rocks) cause the (partly) reflection of a sound wave traveling through it. So this is an acoustic unconformity. It can be related to a change in the lithology, compaction, diagenesis or even just a change in the pore fluid (Nanda, 2016). Confusingly a seismic unconformity can also represent a stratigraphic unconformity.

Unless stated otherwise, the term "unconformity" is mainly used for seismic unconformities in this thesis. 


\section{Conceptual framework}

Continental thinning and stretching leads to the formation of sets of normal faults and the development of graben- or half-graben-structures with rotated blocks, bounded by these normal faults. The main episodes of the rifting process are indicated by unconformities.

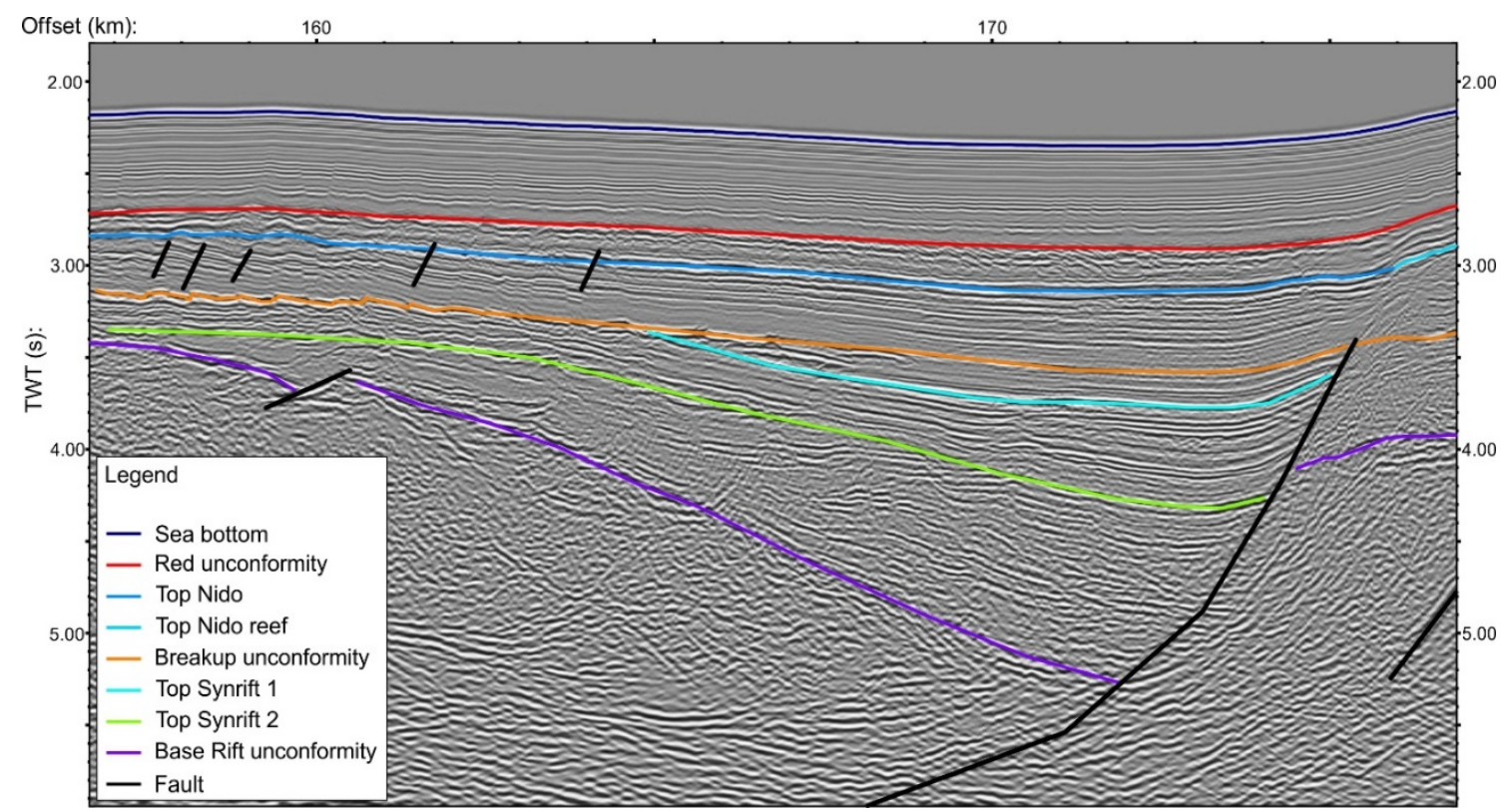

Figure 4: Seismic time section showing a halfgraben in the Dangerous Grounds. At least three rifting episodes (divided by the green and light blue horizons) are visible within the halfgraben. The main tectonic activity is sealed by the Breakup unconformity (orange).

The onset of rifting is associated with a widespread uplift of the area leading to a prominent stratigraphic unconformity. In the text this unconformity is named Rift Onset Unconformity or Base Rift Unconformity. In the interpretation of seismic sections it is marked by a purple horizon.

The graben- or halfgraben-structures on top of the rotated fault blocks provide the accommodation space for sediments provided by the horsts, the tips of rotated fault blocks or other nearby sediment sources. If deposited during the active development of the bounding faults, these sediments show a significant triangular shape (Figure 4). From the time of their accumulation these sediments are addressed as synrift sediments. Different stages of rift development lead to varying sedimentary facies allowing distinguishing different rifting episodes in the seismic image (chapter 1).

The end of the rifting and the opening of the oceanic basin is mostly marked by another prominent stratigraphic unconformity, addressed as "Breakup Unconformity" (BU). This widespread unconformity generally seals the main tectonic activity and it is marked Orange in seismic sections used within our project and given in this text. In the investigation area this unconformity is diachronous and in places coeval with other significant seismic unconformities (chapter 2). On the Reed Bank Block the Breakup unconformity is not developed. This block remained submerged with continuous carbonate sedimentation (chapter 3). 
Another prominent seismic unconformity is located within the Middle Miocene. In this work it is called "Red Unconformity" and it is widespread in the Dangerous Grounds, but not on the Reed Bank Block. This unconformity is one of the main correlative horizons for the dating of formations in the Dangerous Grounds (chapter 3).

The second important correlative horizon is marked by a seismic unconformity representing the top of a widespread carbonate platform (Nido carbonates). This unconformity could be precisely dated by some well data, but is only developed in the easternmost parts of the Dangerous Grounds and within the Palawan Borneo trough (chapter 4).

Next to the rifted continental crust and the Reed Bank Block another important structural element is located in the east. Here the rifted continental crust is overthrusted and the associated wedge (Figure 5) is forming the southern part of Palawan Island and the western part of Borneo.

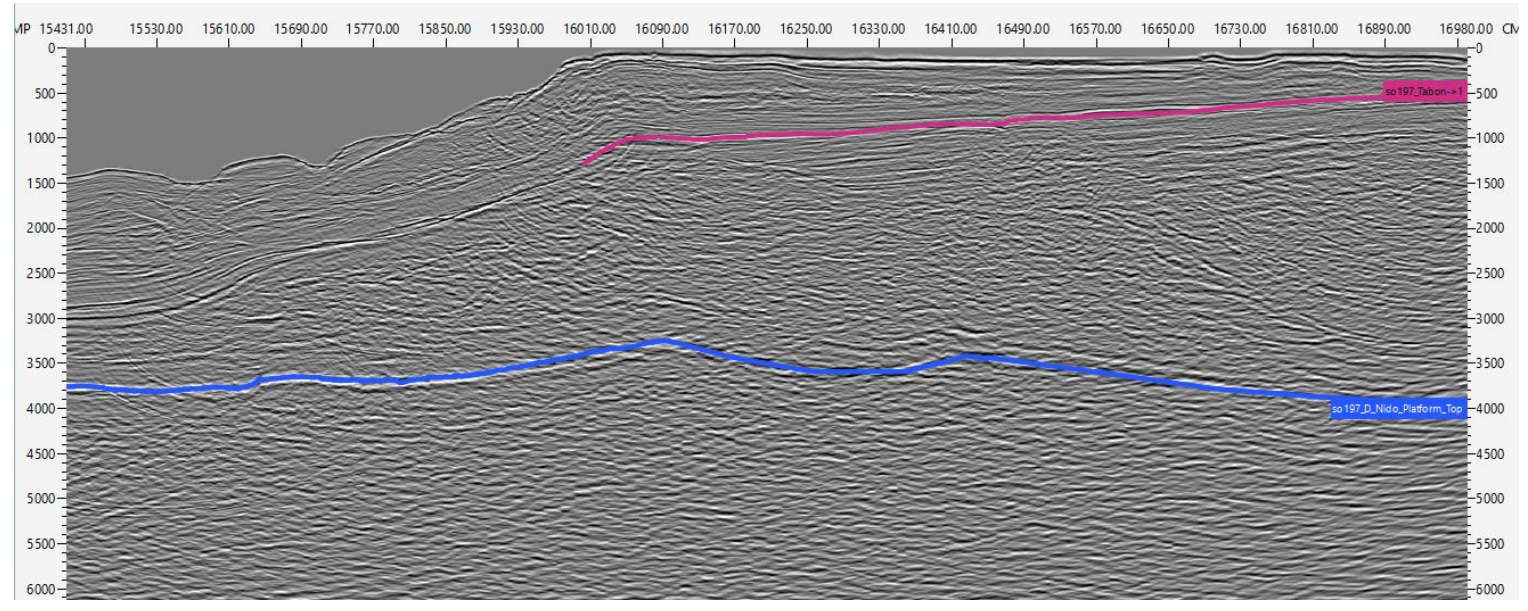

Figure 5: Detail of a seismic line showin the thrusted wedge offshore SW-Palawan. The interpretation of the tops of the two correlative carbonate formations are shown. Top of Tabon Limestone in Purple and top of Nido Limestone in Blue. The thrusted wedge is located between these formations.

The wedge is also causing the continental crust to bend down, leading to the formation of the deep Palawan-Borneo trough. Only on top of this wedge another prominent seismic unconformity is developed. It is associated with the so called Tabon Limestone (Purple in Figure 5). The Tabon Limestone was also used for dating the wedge development. 


\section{Chapter 1: Tectonic evolution of the South China Sea}

\section{Rifting and the origin of extension in the South China Sea}

While there's no doubt on the existence of a wide rifted continental crust at the northern and southern rim of the South China Sea e. g. (Franke et al., 2011; Lin et al., 2018; Savva et al., 2013), several competing models exist aiming to explain the rifting and the subsequent formation of the oceanic basin.

\section{The extrusion model}

One suggestion it that the extension and the subsequent seafloor spreading resulted from the extrusion of Indochina relatively to South China, following India's collision with Asia (Briais et al., 1993; Replumaz and Tapponier, 2003).

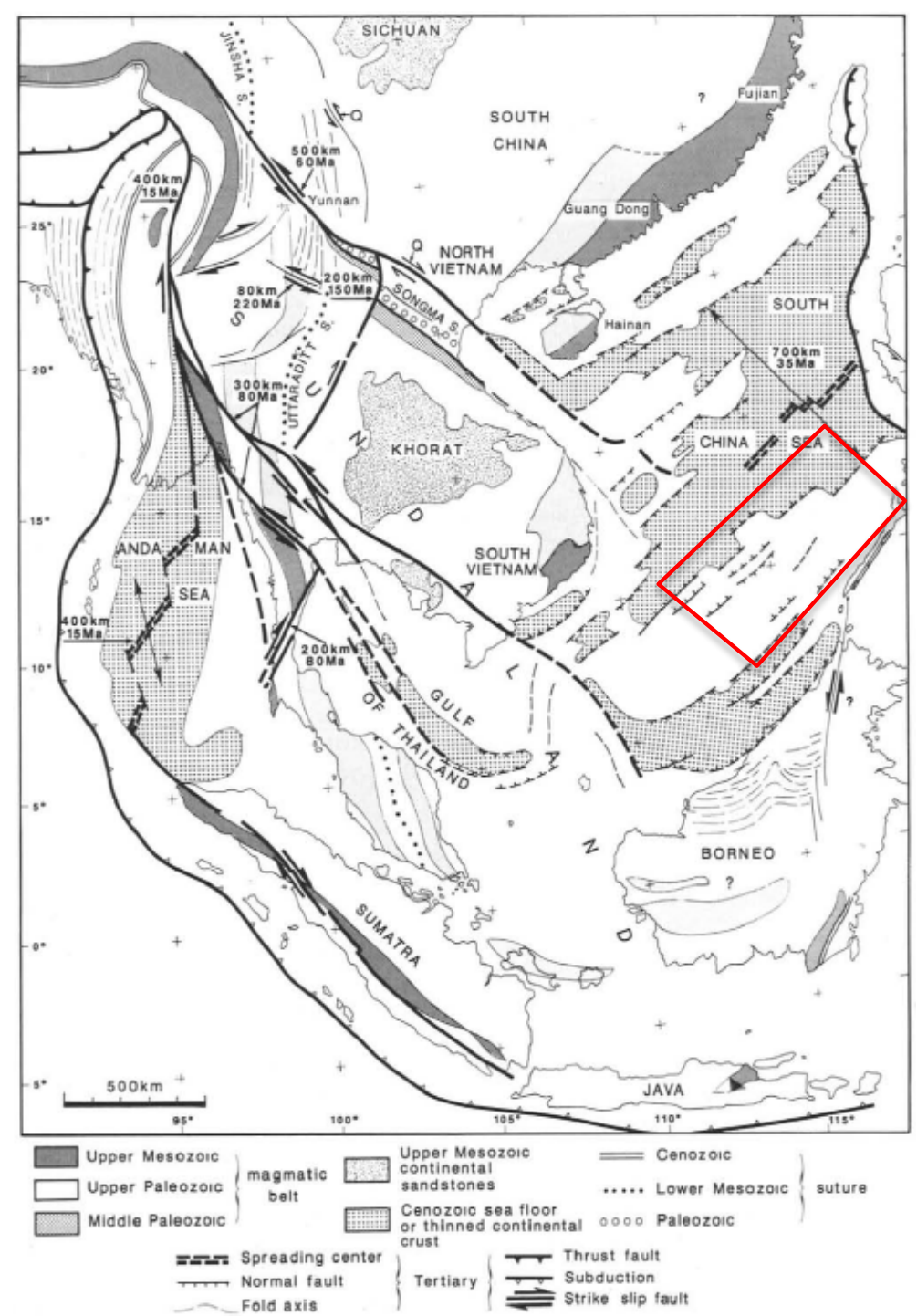

Figure 6: Geodynamic setting in SE-Asia, showing age boundaries and offsets on large strike-slip faults. Minimum offsets (in $\mathrm{km}$ ) and oldest ages of offsets (in Ma) are given. Bold arrows on strike-slip faults represent sense of largest Tertiary movement, small arrows show Quaternary movement. The approximate location of the working area is marked by a red rectangle. Redrawn after Briais et al. (1989). 
Although there is no doubt about the existence of large strike-slip faults, affecting the western South China Sea region (Red River Fault Zone, East Vietnam Boundary Fault (Figure 6)), the timing, sense of motion, and the amount of offset on these structures is still not univocal.
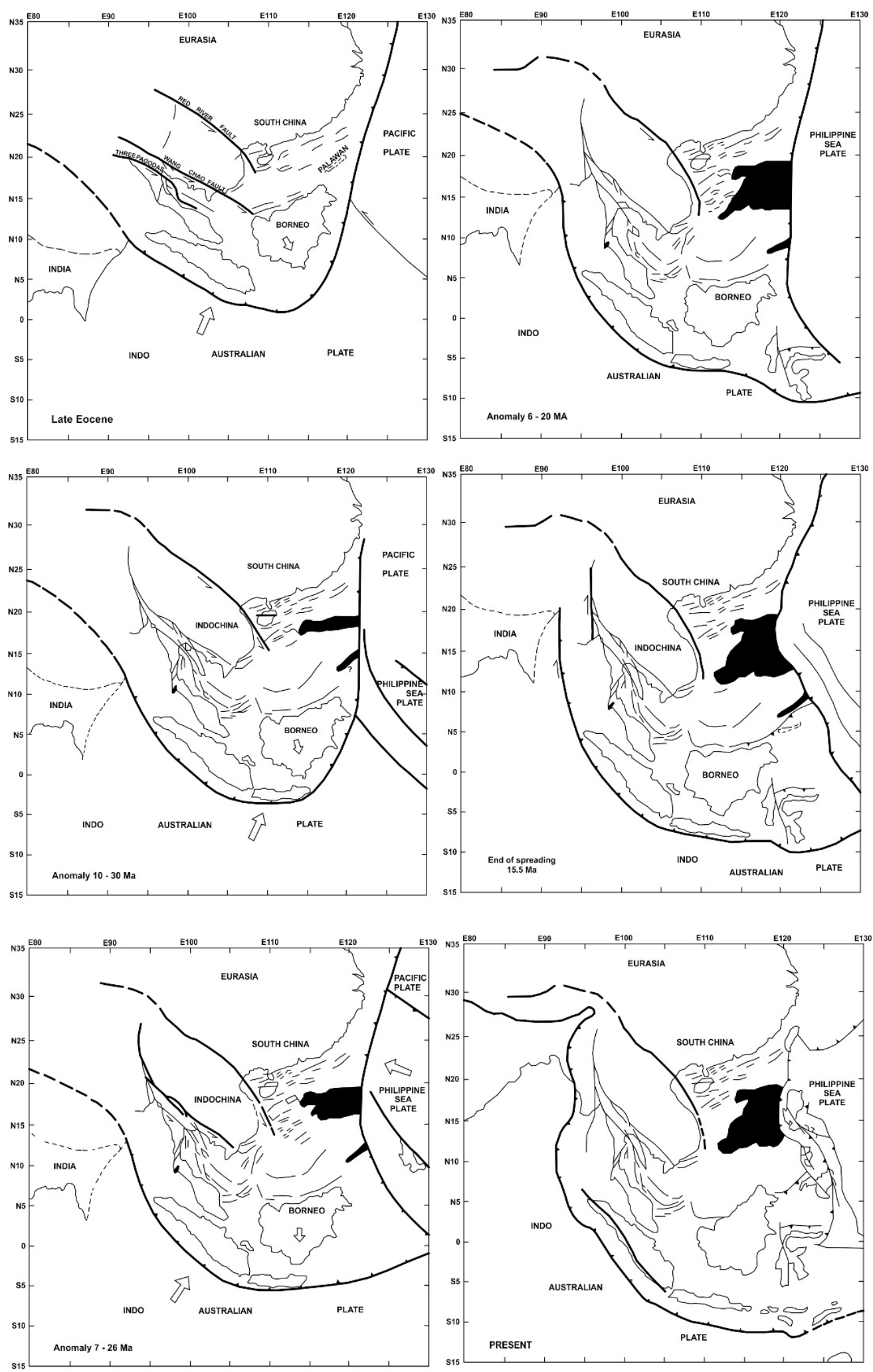

Figure 7: Reconstruction of the opening of the South China Sea. Redrawn after Briais et al.(1993) . 
The rift phases that subsequently resulted in the opening of the South China Sea started in the Late Cretaceous to Early Paleocene with an initial uplift of the rift shoulders followed by widespread erosion and peneplanation (Cullen et al., 2010; Franke, 2013; Pubellier et al., 2003; Schlüter et al., 1996; Shipboard Scientific Party, 2000; Taylor and Hayes, 1980, 1983). Assuming the extension started in the latest Cretaceous (certainly in the Paleocene) there is a timing problem as mainland India collided with Asia not before the Eocene (Ali and Aitchison, 2008).

Most scientific paper today argue that the collision started 50-55 million years ago. Some workers proposed that the collision started earlier from 65-70 Ma. Ali and Aitchison (2008) discussed in detail the collision and came to the conclusion that India collided with an intra-oceanic arc at about $55 \mathrm{Ma}$, with a later impact into Asia starting around $35 \mathrm{Ma}$.

An Early Eocene collision of India and Asia would be hardly in accordance with the initial extension affecting the South China Sea region (Hall et al., 2008; Morley, 2002). Assuming a Late Eocene collision age excludes any relationship between the India-Asia collision and the initial rifting in the South China Sea.

\section{The subduction model}

There is convincing evidence in the mountain ranges in Borneo, indicating that they resulted from subduction/collision (Hutchison, 2005b), a process that is excluded by the extrusion theory. This leads to the popular model of the opening being related to the slab-pull of a proto-South China Sea oceanic crust subducting underneath Borneo between the early Paleogene and the Early Miocene (Hall, 2002; Hall and Breitfeld, 2017; Hinz and Schlüter, 1985; Holloway, 1982; Rangin et al., 1990). The reconstruction of the tectonic development of Asia by Hall (2002) is shown on Figure 8. The first suggestion of a narrow (300 km wide) proto-South China Sea, subducting underneath NW Borneo along a SW migrating collision, was given by Rangin et al. (1990). Cullen (2010) interprets minimal Oligocene-Miocene subduction and suggests rifting in the South China Sea was accommodated over a wide zone by multiple mechanisms. Minimal subduction is preferred here as the better explains the narrow volcanic arc, if the Cagayan ridge in the Sulu Sea is considered as being the arc of the proto-SCS subduction. If so, the force of the slab-pull might not have been sufficient to initiate rifting in the SCS. Moreover, the formation of the subduction zone of the protoSCS along its southern margin was from the SW to the NE. If the opening of the SCS was caused only by subduction it must have started in the SW-subbasin and then jumped into the east subbasin, contradicting the research of Barckhausen et al. (2014; 2004). 

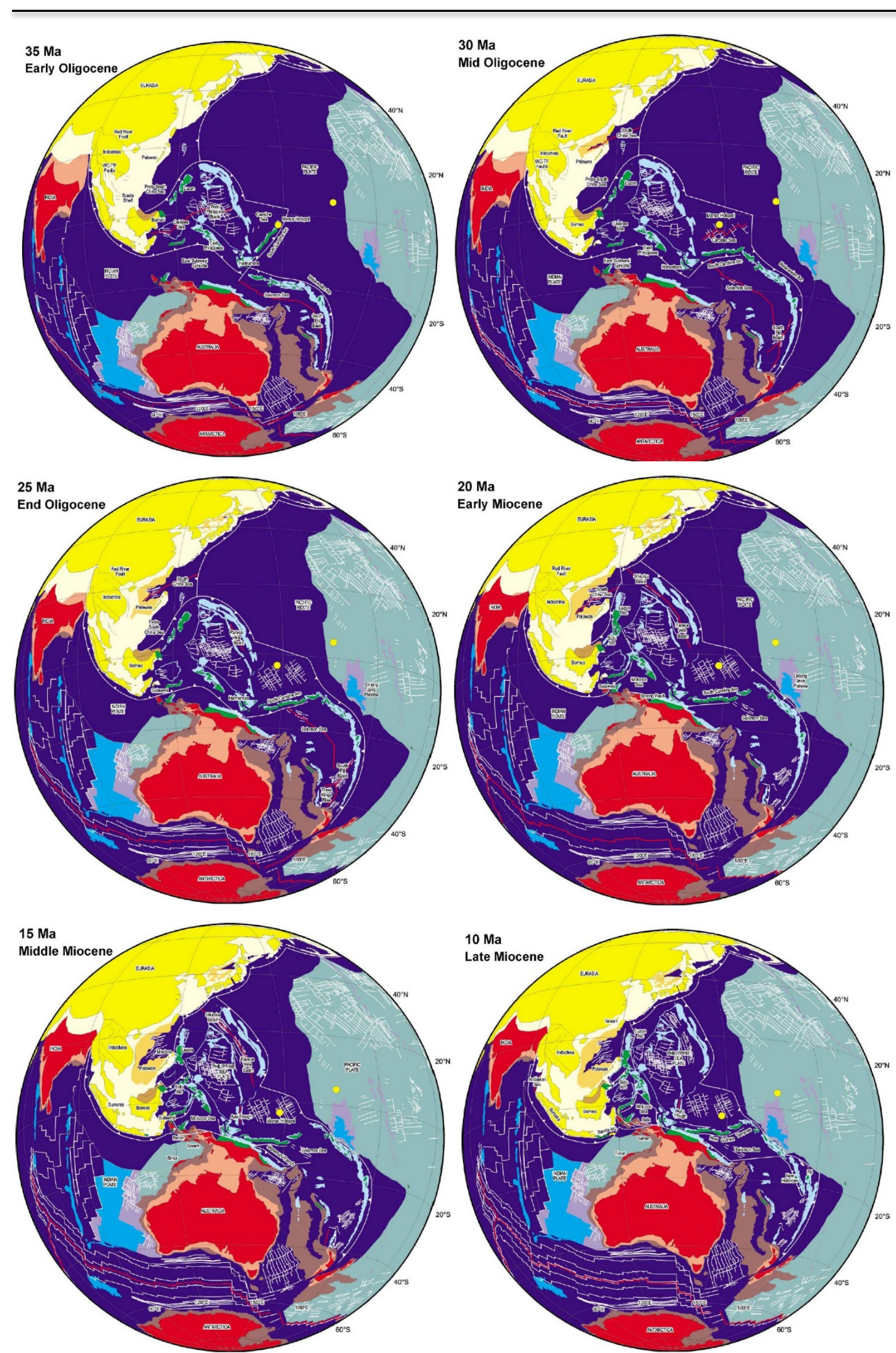

Figure 8: Reconstruction of the tectonic history of Asia by Hall (2002). Examples are given for 5 My intervals between $35 \mathrm{Ma}$ and $10 \mathrm{Ma}$. The existence of a Proto-South China Sea is assumed. 


\section{The multiple mechanisms model}

The multiple mechanisms idea leaves room for other models. One is back-arc-spreading, triggered either from the subduction of the Indo-Australian plate beneath Sumatra or of the Pacific plate beneath Eurasia. However, the distance to the subduction of the Indo-Australian plate is quite large and a well-defined back-arc is located much to the south of the South China Sea.

This leaves basically two alternatives to the slab-pull and extrusion model: Paleo-pacific plate subduction and an orogenic collapse. Also a combination of several processes and hybrid models seems possible.

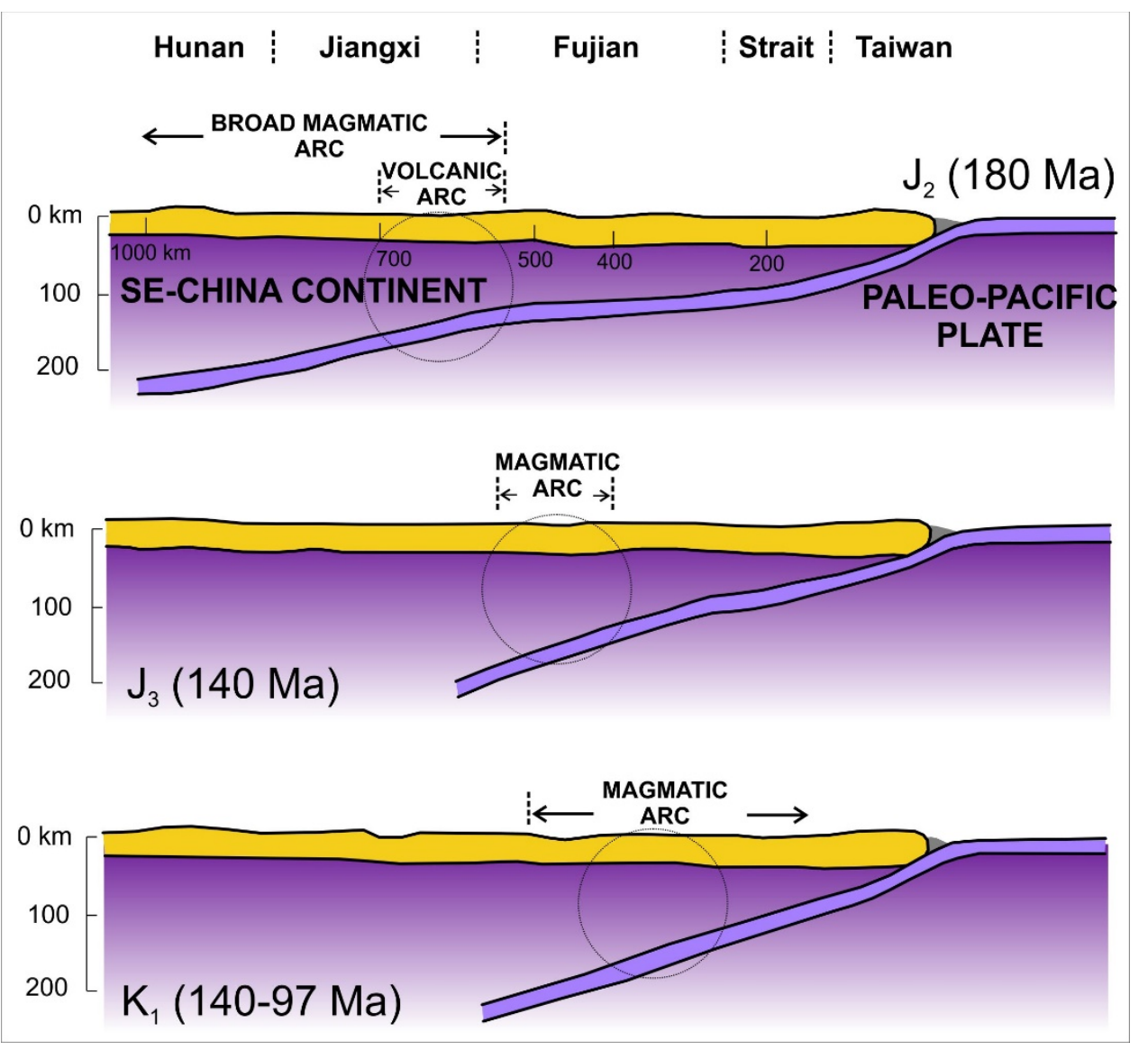

Figure 9: Schematic drawing of the slab-rollback underneath eastern China indicating the movement of the magmatic active zone towards the subduction zone. The transect is located in the northeastern SCS area near Taiwan. Redrawn after Zhou and Li (2000).

For the Mesozoic subduction of the paleo-Pacific plate underneath SE China it was suggested that during the period from 180 to $80 \mathrm{Ma}$, the dip angle of the slab increased from a very low angle to a median angle (Zhou and Li, 2000). Consequently, magmatic activity of the SE China continental margin migrated to the southeast, from 800-1000 km inland to only 100-200 km inland.

Such a slab rollback around greater SE Asia may have also caused the early episode of extension. In any case it can be expected that various degrees of mantle wedge melting and basaltic underplating during the subduction provided the heat necessary to weaken the lower and middle crust, allowing the generation of a wide rift (Franke et al., 2014). 


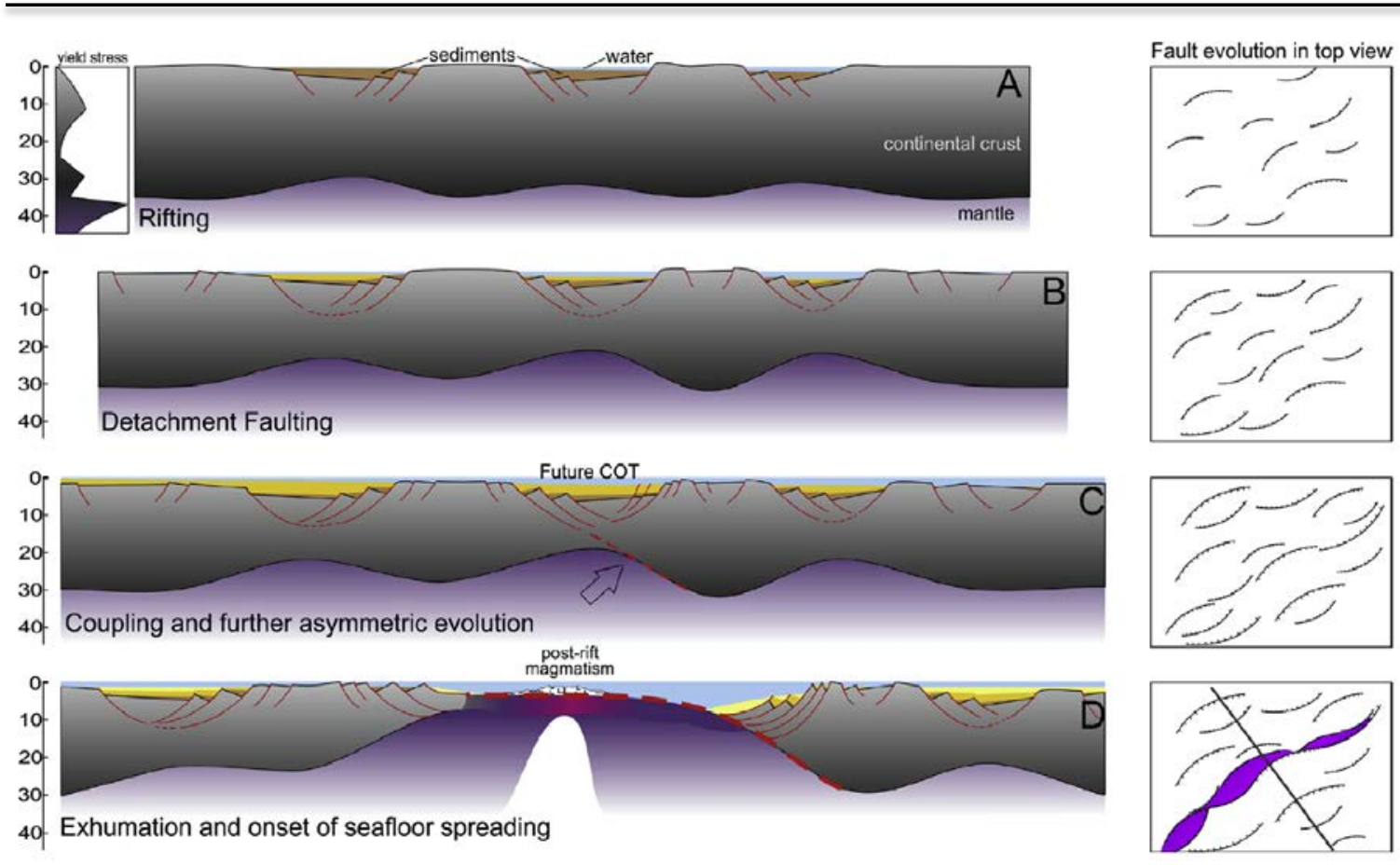

Figure 10: Sketches illustrating the early evolution of the South China Sea rift (not to scale). (A) In the rifting stage brittle deformation in the upper crust results in basin formation while ductile extension in the middle crust is compensated by doming in the Moho. Lacustrine / deltaic sedimentation prevails. (B) Extension localizes in the rift basins. The faults are becoming shallower and detachment faulting initiates. Continuing extension in the middle crust is compensated by further Moho uplifts beneath the rift basins. Lacustrine / deltaic sedimentation continues. (C) Crustal thinning approaches the point where the entire crust becomes brittle and crustal-scale faults at the rim of crustal blocks cut through the entire crust. Sedimentation is shallow marine. (D) Mantle exhumation along a detachment fault that develops from the previous crustal-scale fault at the rim of crustal blocks. When the asthenospheric mantle reaches the surface accretion of oceanic crust and post-rift volcanism takes place. (Franke et al., 2014)

\section{The breakup}

A wide variety of ages has been proposed for the breakup unconformity, even at the well explored South China margin. Feng et al. (1992) proposed a Late Eocene/Early Oligocene age ( $35 \mathrm{Ma}$ ) while Edwards (1992) suggested a Late Oligocene age ( $25 \mathrm{Ma}$ ) and Lüdmann and Wong (1999) considered a Middle Oligocene age ( $32 \mathrm{Ma}$ ) for the breakup unconformity. From nanofossil determinations conducted at Petroleum industry wells in the Pearl River Mouth basin the end of rifting can be limited to earlier than about 28 Ma (Clift et al., 2001). The identification of this unconformity is complicated by the fact that during the proposed breakup time there was a deep marine trough in that region (Clift et al., 2002b). ODP drilling site 1148 revealed water depths of more than $500 \mathrm{~m}$ at the time of the breakup (Shipboard Scientific Party, 2000). Drillings on the Reed Bank block also identified deepwater, clastic sedimentary rocks of pre-Middle Eocene age (Taylor and Hayes, 1980). Therefore a continuously developed breakup unconformity may not be expected.

Ru et al. (1994) and Cullen et al. (2010) suggested from the fact that the breakup is diachronous that the corresponding unconformity has to be diachronous too. They suggest that the Breakup unconformity gets younger by $10 \mathrm{Ma}$ from East to West. This shows the necessity to relate the age of this unconformity to specific geographic regions. 
Perhaps the best evidence for a breakup unconformity was found in the northeastern South China Sea, close to Taiwan where a missing section ranges at least from 37 to 30 Ma as judged by the ages of its youngest underlying and oldest overlying sediments (Lin et al., 2003). Oligocene uplift was followed by rapid post-breakup subsidence (about 30 - $18 \mathrm{Ma}$ ).

For the Pearl River Mouth Basin the hiatus around the breakup unconformity was identified based on fossil records in wells (Zhou et al., 1995) this provides an approximate time range for the hiatus from 33 - 32 Ma in the eastern and from 28 - 27 Ma in the western Pearl River Mouth basin. ODP site 1148 in contrast revealed the most significant unconformity at 23.8 Ma, evidenced by sharp changes in the geochemistry and a total of 2.5 to 3 Ma hiatus adjacently before 23.8 Ma (Shipboard Scientific Party, 2000). This hiatus was explained by a ridge jump towards the south. This timing fits well with the proposed breakup related hiatus from 23 - 22 Ma for the Qiongdongnan basis (Zhou et al., 1995).

In the Vietnamese Cuu Long basin rifting continued until the end Oligocene time when a distinct unconformity at the Oligocene/Miocene boundary marks the onset of post rift sagging (Fyhn et al., 2009). This unconformity was interpreted as breakup-related and traced seaward into the Nam Con Son basin. There it indicates the onset of a second rift phase in the basin. This implies that along the western margin of the South China Sea there is a link with the active period of major strike-slip movement along the Red River fault, extending from the Himalayan to offshore Vietnam from 25 to 17 Ma (Morley, 2002).

In the northeastern Dangerous Grounds, the Reed Bank and the NW Palawan shelf the rift to drift transition is directly overlain by a widespread carbonate platform (Nido Limestone). Ages for the breakup are mainly derived from these carbonates, which were drilled by several commercial wells. The top of these carbonates is at Lower Miocene level ( $22-\sim 17$ Ma (Schlüter et al., 1996), 22 $18 \mathrm{Ma}$ (Steuer et al., 2013), Table 4). Offshore NW Palawan the platform carbonate formation was established in the Early Oligocene (Grötsch and Mercadier, 1999) respectively in the upper Early to lower Late Oligocene ((Steuer et al., 2013), Table 4) and the formation of the limestones ceased in the Early Miocene ( 20 Ma ((Steuer et al., 2013), Table 4)). Several dredge samples of Late Oligocene to Early Miocene platform carbonates, collected south and southwest of Reed Bank also confirm this interpretation (Kudrass et al., 1986). This indicated a mid-Oligocene age for the breakup in the Reed Bank and NW Palawan area, similar to the conjugate margin offshore South China (Pearl River Mouth basin).

Due to a large number of unconformities in the southern South China Sea some confusion exists about a potential breakup unconformity there. (Hutchison, 2004) focused on the southern Dangerous Grounds where he refers to the most prominent unconformity as Mid Miocene Unconformity (MMU). The overlying basal draping strata were dated $16 \mathrm{Ma}$, however, he pointed out that the unconformity represents a hiatus of about $3-5$ Ma. Offshore NW Borneo 
Clift et al. (2008) suggested that this unconformity is an equivalent of the Deep Regional Unconformity ( $16 \mathrm{Ma}$ ) that is widespread offshore Sabah. However Cullen (2010) proposed that the Deep Regional Unconformity (DRU) is associated with tilting and uplift of the Sabah margin and thus is a local feature. He suggested it as being inappropriate to consider correlating the MMU to the DRU. Ingram et al. (2004) suggested an age of $21 \mathrm{Ma}$ for the top of the downgoing continental plate offshore NW Borneo, which means that a potential breakup unconformity would be older than this, while Cullen (2010) proposed an age of 18 - 15.5 Ma for this unconformity, which he refers to as South China Sea Unconformity (SCSU). Hall and Morley (2004) suggested a 17 - 16 Ma old syn-rift to drift unconformity at the same stratigraphic position. Drilling results in the southern Dangerous Grounds confirmed the proposed age of 16 Ma for the erosion at the MMU that preserved much of the sedimentary section close to the Luconia platform margin, but has eroded much of the 25 - 16 Ma section further from the margin (Thies et al., 2005).

\section{Seafloor spreading}

In the Early Oligocene crustal extension and thinning reached a point where oceanic spreading initiated and the formation of the deep-sea basin of the Central South China Sea began. Shipboard micropaleontologic results of IODP Expedition 349 (South China Sea Tectonics) and Ar/Ar dating of the basement basalt near the fossil spreading center indicate that seafloor spreading took place between $\sim 33$ Ma to 16 Ma (Ding et al., 2018). Since very few wells penetrated the igneous crust in this basin the identification of seafloor spreading anomalies in magnetic data provides other important constraint on the age of the seafloor with the potential of precisely dating the major tectonic events during the opening of the basin. The seafloor spreading history of the South China Sea has been interpreted in different ways in the past and the debate over the correct timing of the major tectonic events is still on. Conditions for magnetic measurements are difficult in the South China Sea due to its location in vicinity of the so-called equatorial electrojet, an ionospheric current system that causes severe time varying disturbances of the magnetic field. In addition to that the oceanic basin is relatively small, seafloor spreading rates were slow and the spreading was not continuous but interrupted by at least one ridge jump and associated changes in the spreading direction. Additionally the oceanic crust shows many seamounts producing local magnetic anomalies which disturb the seafloor spreading pattern (Barckhausen et al., 2014). Most authors agree on a decreasing age of the oceanic crust towards the southwest. In the northeastern part of the South China Sea, Hsu et al. (2004) interpreted Late Eocene / Early Oligocene oceanic crust (37.8 $30.1 \mathrm{Ma}$ ) but the nature of the crust is ambiguous. Structural data and seismic velocities from the University of Texas (unpublished) indicate attenuated continental crust at the position where magnetic spreading anomalies have been interpreted.

The timing of seafloor spreading in the central South China Sea of 32 - 15.5 Ma (Briais et al., 1993; Taylor and Hayes, 1983) has been revised to 31 - 20 Ma by Barckhausen et al. (2014). 


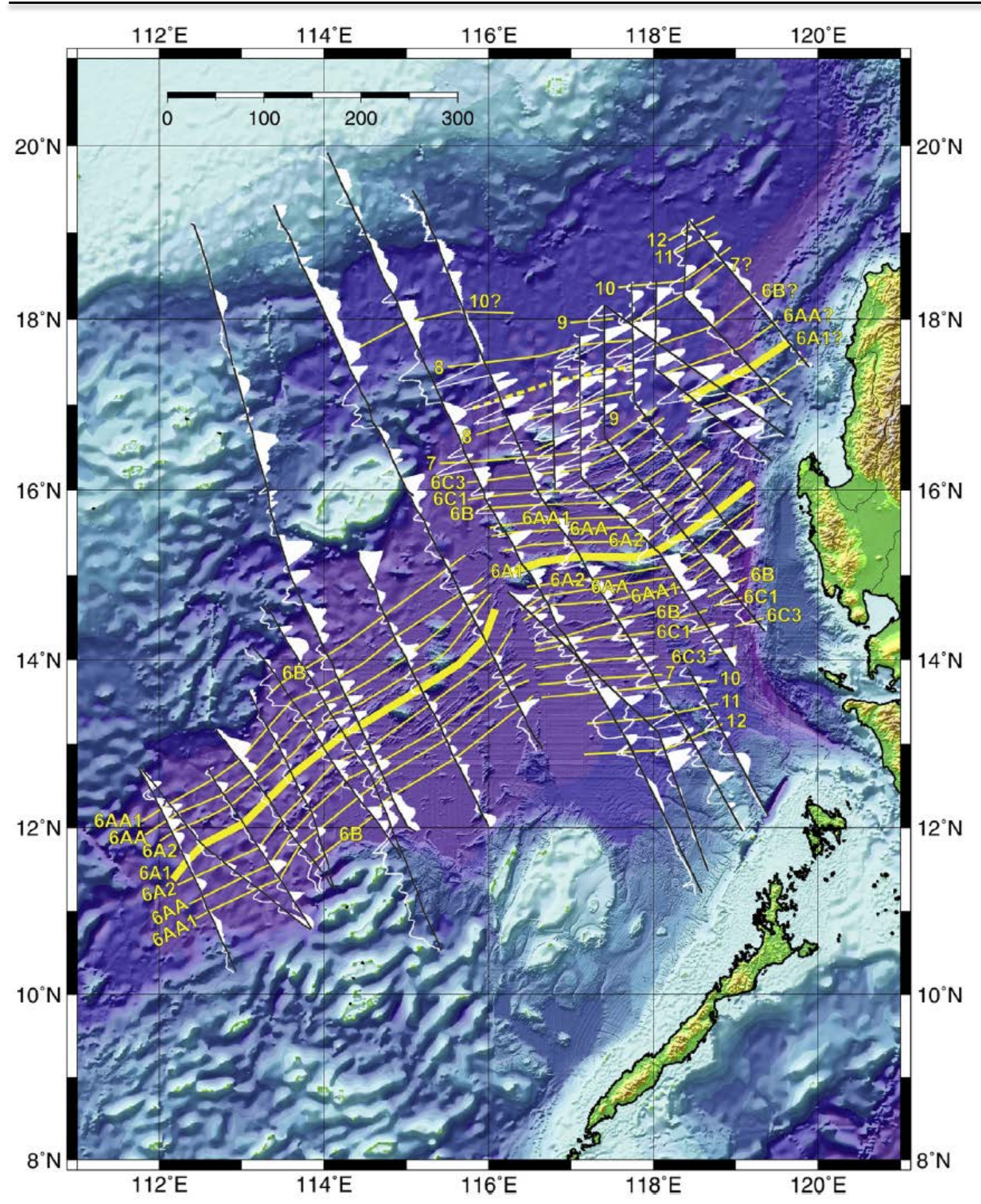

Figure 11: Bathymetric map of the SCS with magnetic profiles shown as wiggles along shiptracks and magnetic anomaly interpretation (yellow). Heavy lines are abandoned spreading ridges, numbers indicate magnetic crons. Figure from Barckhausen et al. 2014

The main argument for older ages are resulting spreading rates which are continuously at levels between 28 and $40 \mathrm{~mm}$ / yr (half spreading rate) with the higher spreading rates at the younger ages. In contrast to that the model of Briais et al. (1993) and the similar but extended model of Yeh et al. (2010) assume a decline in spreading rates down to very low rates of only $15 \mathrm{~mm} / \mathrm{yr}$ over most of the spreading history of the South China Sea with a sharp increase shortly before the end of seafloor spreading which is quite unusual (Barckhausen et al., 2014). 
The main argument for younger seafloor spreading ages are findings from the Phu Khan basin close to Vietnam at the western margin of the South China Sea. Here the rifting did not cease before 12 - $10 \mathrm{Ma}$, a variance with models derived from magnetic anomalies recognized over the oceanic portion of the South China Sea (Savva et al., 2013). Offshore Vietnam three stages of extension are clearly identifiable with ages well constrained by wells. The oldest rift sequence is identified from basement to Oligocene horizons (32 Ma). A second one from Oligocene to Middle Miocene (15.5 Ma) and a third one from Middle Miocene to Late Miocene (10.5 Ma). These three rift structures have been formed by at least two directions of extension, the first was North-South and the second Northwest-Southeast. The distinct Mid-Miocene (15.5 Ma) horizon is tilted, as well as parts of the subsequent fan shaped infilling. If the older seafloor spreading ages turn out to be correct, younger extension may be attributed to movements along the Red River fault, which in that case would have been most active from the Middle Miocene onwards. This relationship is also supported by the fact that Middle to Late Miocene extension is only found on the western margin. The spreading duration from 33 Ma to $16 \mathrm{Ma}$, as supposed by Ding et a. (2018) however is coincident with the collisions between Palawan and Borneo and Mindoro-Central Philippines (Clift et al., 2008; Cullen et al., 2010; Ding et al., 2018; Hutchison, 2004), suggesting a causal relationship between the cessation of spreading and collision events.

\section{Palawan Island}

The island of Palawan is located at the eastern margin of the South China Sea. The island itself is elongated and more or less orientated in NNE-SSW direction (see Figure 3, Figure 13). Geologically the island can be divided along the so-called Ulugan Fault Zone. The Ulugan Fault Zone is named after Ulugan Bay in the central part of Palawan. The fault zone runs almost in N-S direction thrugh the bay and across the Island, dividing it into two parts. The northern part of Palawan is dominated by rocks of continental affinity which were likely rifted from mainland China. It consists of Jurassic olistostromes containing olistoliths of Permian limestone, Permian and Triassic chert, sandstone and basaltic rocks in a predominantly mudstone matrix (Aurelio, 2010; Suzuki et al., 2000). An analysis of the detrital zircon age distributions indicates that the northern part of Palawan was attached to the South China margin until the breakup of the SCS (Shao et al., 2017). The southern part is dominated by rocks of oceanic affinity. It is comprised mainly of a thrusted wedge of Eocene rocks that has been overrun by Ophiolites in the Late Eocene (Aurelio, 2010; Encarnacion, 2004; Rammlmair et al., 1987; Wolfahrt et al., 1986). 


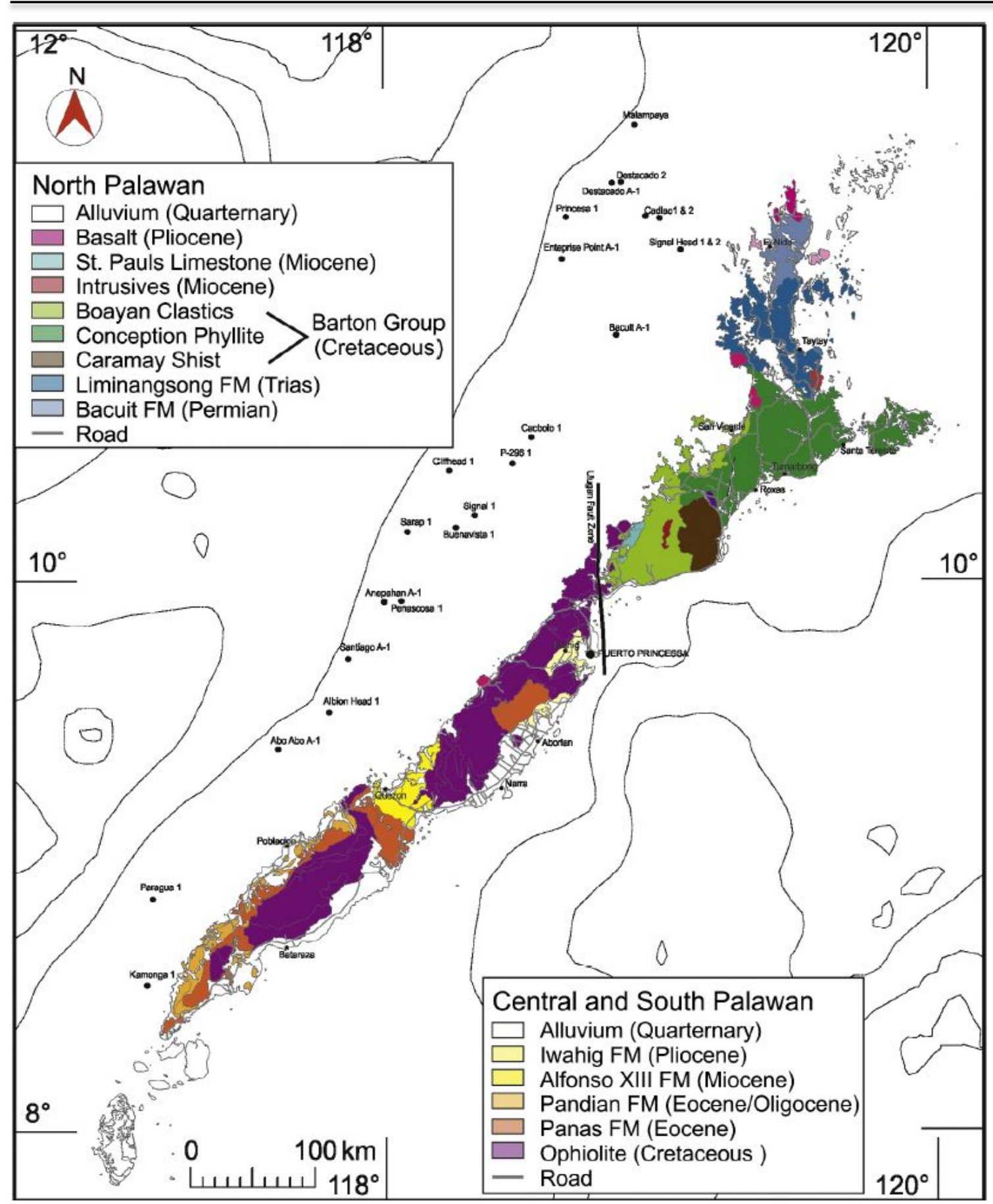

Figure 12: Geologic map of Palawan Island. Offshore wells are indicated. Picture from (Steuer et al., 2013)(Chapter 4)

The timing of the formation of southern Palawan was investigated using two prominent limestone formations the Oligocene to Early Miocene "Nido" limestone and the Middle to Late Miocene “Tabon” limestone. From carefully dating these limestones it was deduced that the thrusted wedge was not present in the southern Palawan area before $18 \mathrm{Ma}$ and that the thrusting continued until 5 - 7 Ma (Steuer et al., 2013). Ilao et al. (2018) argue for a slightly older age for the cessation of the wedge development. Based on their investigation of two wells and a 3D-seismic block they state that the convergence ended at $9 \mathrm{Ma}$. After the end of conversion and thrusting the wedge was subjected to gravity sliding, especially near the wedge front. 


\section{The Dangerous Grounds}

The island of Palawan is bound to the west to a vast area of highly attenuated and rifted continental crust. The half-grabens are filled with Cenozoic sediments, but the sediment input was not sufficient to fill them completely (Steuer et al., 2014). So the rift-structure with the tilted and elevated rift blocks is still visible in the bathymetry (Figure 11). The tips of the tilted blocks are in many times in shallow water depths, allowing the development of reefs. The occurrence of many reefs and shoals, rising rapidly from quite significant water depths, represented a high thread to ships sailing that area. Therefore, this area was called "Dangerous Grounds” and that name prevailed.

The Dangerous Grounds stretch from the Reed Bank block in the north to the Luconia platform in the south. Towards the east they are bounded by Palawan Island and Borneo and they stretch towards the west until the Continent Ocean Boundary.

This strongly rifted piece of continental crust dips down underneath Palawan Island and Borneo forming the Palawan - Borneo through.

\section{Summary for the Palawan area}

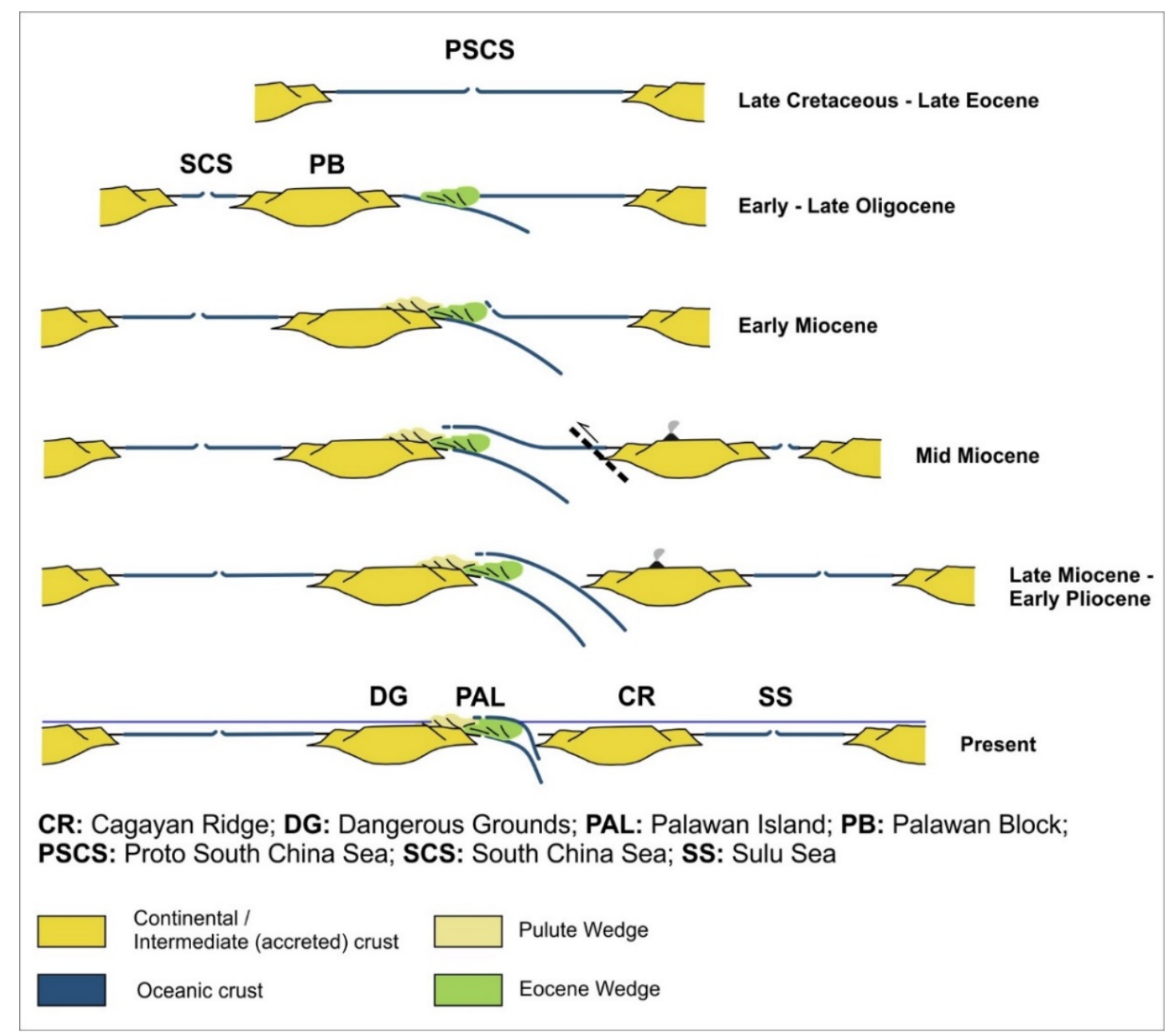

Figure 13: Schematic drawing of the opening history of the SCS. Redrawn after Savva (2013); Holloway (1982) and Kudrass (1990). Drawing not to scale. 
Figure 13 was developed together with D. Savva and summarizes schematically the tectonic history of the Palawan area. It is assumed that the "break" in the oceanic crust of the Proto-SCS occurred at or very close to the old spreading center. Indications for that hypothesis are taken from Rammlmair et al. (1987), who indicates a relatively high temperature for the obducting ophiolites onshore Palawan island. The convergence led to the formation of two accretionary wedges which were thrusted upon the continental crust of the Dangerous Grounds and were overthrusted by the hot ophiolite. A second "break" in the oceanic crust of the Proto-SCS occurred close to the continental block that today contains the Cagayan ridge. The subduction of this part of the oceanic crust led to the volcanism of the Cagayan ridge (Kudrass et al., 1990). This volcanism was not strong enough to be related to the subduction of a large oceanic crust, so it is assumed that only little subduction happened beneath the Cagayan ridge. The convergence continued until the (almost) full closure of the Proto-SCS. Only the western sub-basin of the Sulu Sea is left, but it is completely underlain by continental crust (Chapter 5). 


\section{Chapter 2: Techniques and methods}

\section{Seismic interpretation}

A careful and detailed interpretation of seismic lines builds the foundation of this work. The interpreted horizons are correlated, if possible, with well markers and assigned ages based on well and dredge data.

\section{Data base}

For this work a set of 2D-seismic lines, shot by BGR in the last 30 years, was available. This data base was enlarged by several surveys, shot by the petroleum industry. All in all over 30,000 km of seismic lines were interpreted (Figure 14). The full list of seismic surveys with the amount of lines in each survey is given in the appendix.

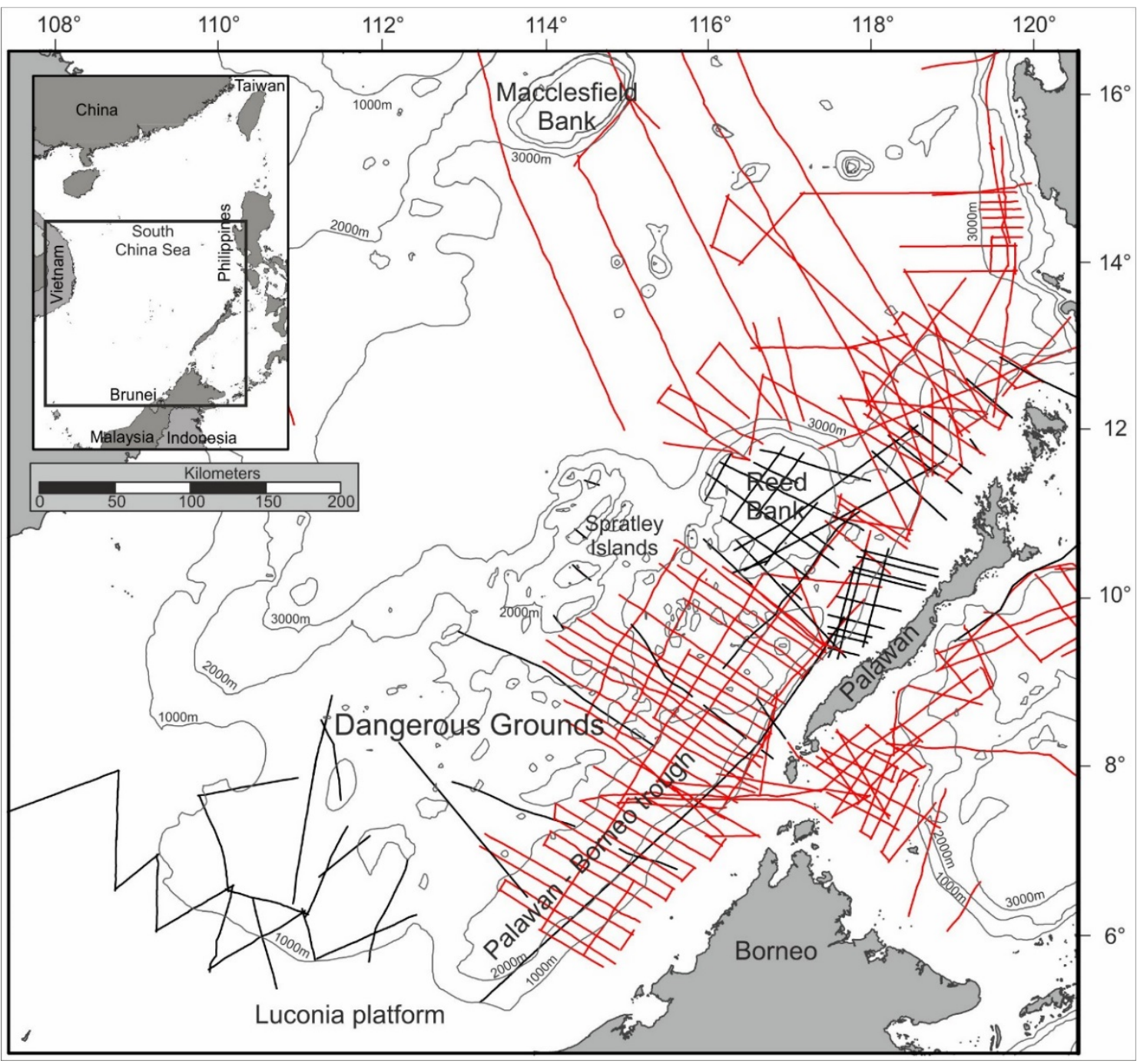

Figure 14: Overview of used seismic lines in the Dangerous Ground: Seismic lines shot by BGR are colored red 


\section{Data loading and used software}

A set of several software products was used for the seismic interpretation. The data loading and a first interpretation was done using the IESX-Module of GeoFrame (Schlumberger). Seismic lines, provided by the petroleum industry consist of a file with the actual seismic data in SEG-Y- format and a navigation file with the coordinates of the lines. Usually the second file is an ascii-tabular text file, containing the coordinates of every shotpoint of a line. In the data loading process both files were combined and stored in the software. Since the navigation file contained the coordinates of every shotpoint (SP) and the seismic traces were processed to "common depth points" (CDP), a correct CDP/SP relation (usually 1/3) had to be assigned.

After the loading in GeoFrame the seismic lines were transferred in the Kingdom Software Suite (IHS) for interpretation. All available well data were also loaded into the Kingdom suite. This software package was then used for the main part of the project.

\section{Seismostratigraphic concept and Interpreted horizons}

Based upon well data and older publications (Hinz and Schlüter, 1985) new seismostratigraphic concepts were developed for the NW-Palawan shelf, the SW-Palawan shelf and the Dangerous Grounds (Figure 15).

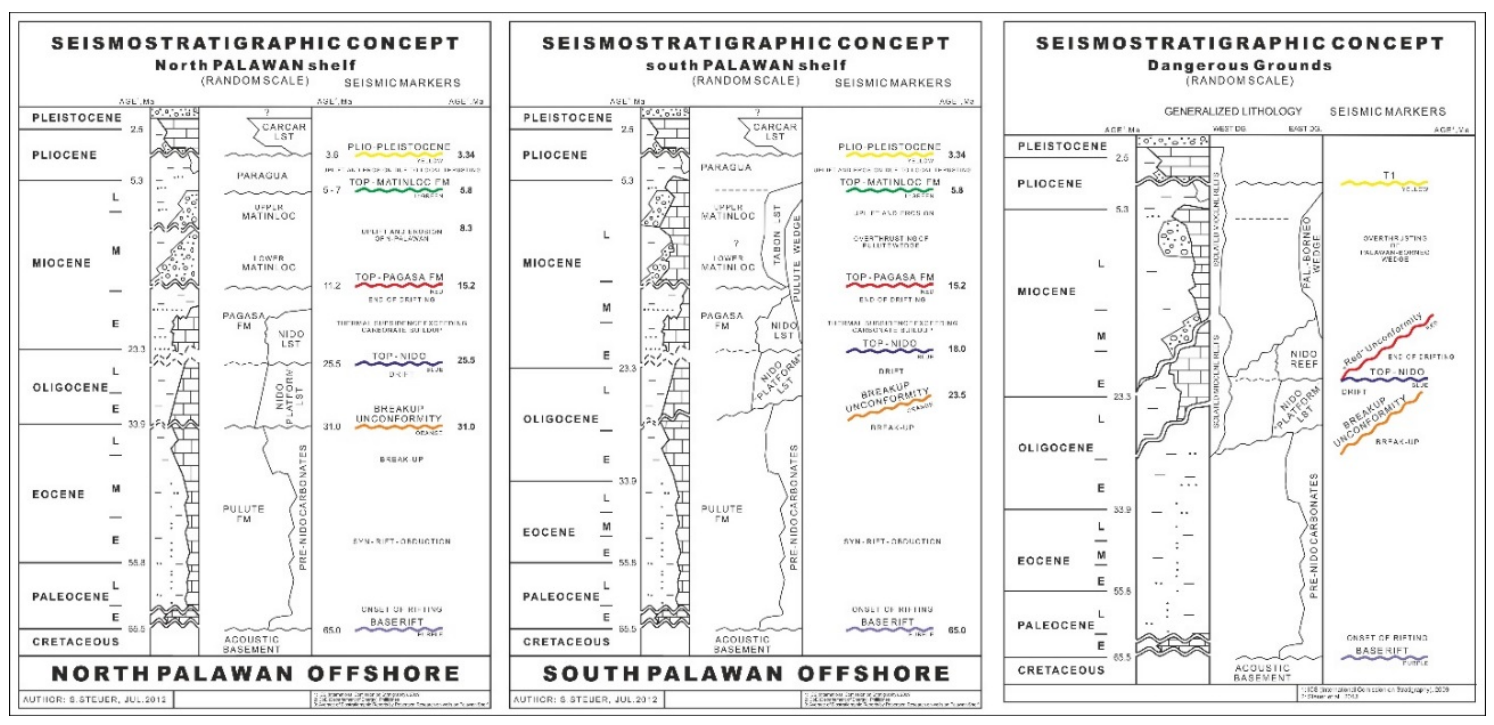

Figure 15: Seismostratigraphic concepts for the southeastern part of the South China Sea 
This division was necessary because of the sometimes different nature of interpreted unconformities (Chapter 3). An example is the "Red" unconformity. Offshore northwest Palawan this unconformity gets weaker towards the west and even turns into conformity close to the continent-ocean boundary (Hinz and Schlüter, 1985). The "Red" unconformity also turns into a strong diachronous event in the Dangerous Grounds (Steuer et al., 2014). In these concepts the main marker horizons were defined and dated (Steuer et al., 2013). These horizons were primarily interpreted in the seismic lines. Whenever necessary additional horizons were defined and interpreted. This was e.g. necessary to distinguish between different variations of a single horizon. The unconformity " $D$ ” by Hinz and Schlüter (1985) for example represents not only the top of a carbonate platform (Nido), but also a chance in clastic lithology or even an erosional unconformity. To indicate these changes three different horizons were used for the interpretation of " $D$ ".

To interpret the seismic unconformities mainly positive amplitudes were picked, only the interpreted base of the Nido carbonates, in areas where it does not represent the breakup unconformity, is represented by a negative amplitude. 


\section{Main stratigraphic intervals}

The interpreted horizons from Base rift to the Sea bottom divide the seismic section into five main stratigraphic intervals (Nido Formation and Nido Reefs are treated as one interval).

\begin{tabular}{|c|c|c|c|c|c|c|}
\hline Seismic & $\begin{array}{l}\text { Schematic } \\
\text { drawing }\end{array}$ & Amplitude & Frequency & Continuity & Geometry & Geology \\
\hline 每 & 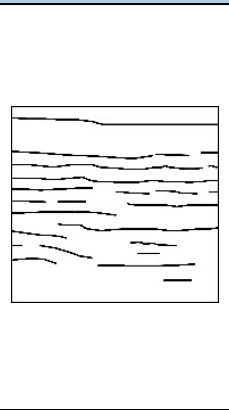 & $\begin{array}{l}\text { medium to } \\
\text { High }\end{array}$ & $\begin{array}{l}\text { medium to } \\
\text { high }\end{array}$ & continuous & $\begin{array}{l}\text { parallel to } \\
\text { sub-parallel }\end{array}$ & $\begin{array}{l}\text { Youngest unit, deposited } \\
\text { after the Matinloc } \\
\text { formation. Silty } \\
\text { claystones to siltstones } \\
\text { with interbeds of fine } \\
\text { sandstone. } \\
\text { On the Palawan shelf } \\
\text { carbonates on top of the } \\
\text { unit, reaching the sea } \\
\text { bottom (Carcar limestone) } \\
\text { Age: Pleistocene }\end{array}$ \\
\hline Fen & & $\begin{array}{l}\text { low to } \\
\text { medium }\end{array}$ & medium & continuous & parallel & $\begin{array}{l}\text { Pagasa Formation, } \\
\text { composed of calcareous } \\
\text { silty claystone. Becoming } \\
\text { with depth marly, } \\
\text { interbedded with thin, fine } \\
\text { grained sandstone } \\
\text { Age: Lower - Middle } \\
\text { Miocene }\end{array}$ \\
\hline $\int_{i=2}=$ & & $\begin{array}{l}\text { medium to } \\
\text { high }\end{array}$ & medium & discontinuous & $\begin{array}{l}\text { subparallel } \\
\text { to chaotic }\end{array}$ & $\begin{array}{l}\text { Nido Formation } \\
\text { Carbonate reef } \\
\text { Fossiliferous, micritic } \\
\text { limestone } \\
\text { Age Lower Miocene - } \\
\text { recent (sometimes) }\end{array}$ \\
\hline 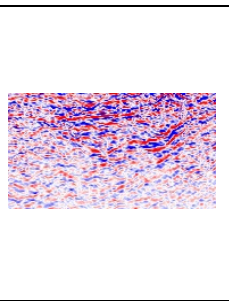 & & $\begin{array}{l}\text { medium to } \\
\text { high }\end{array}$ & $\begin{array}{l}\text { medium to } \\
\text { high }\end{array}$ & discontinuous & $\begin{array}{l}\text { subparallel, } \\
\text { fan-shaped }\end{array}$ & $\begin{array}{l}\text { Syn-rift } \\
\text { continental to shallow } \\
\text { marine deposits } \\
\text { Age: Upper Cretaceous - } \\
\text { Paleogene } \\
\text { Not drilled in the } \\
\text { Dangerous grounds and } \\
\text { the Palawan shelf }\end{array}$ \\
\hline
\end{tabular}

Table 2: Overview of the main interpreted stratigraphic units, showing the characteristic seismic representation. 


\section{Interpreted faults}

Generally, faults are mainly divided into normal and thrust faults in the interpretation. Thrust faults are restricted to the thrusted wedge underneath Palawan and Boneo.

Due to the sometimes sparse density of seismic lines, interpreted faults are hard to connect across several seismic lines. Nevertheless, it was possible to assign some interpreted normal faults to single (half-) grabens. In close collaboration with TOTAL a larger set of NE-striking normal faults was interpreted offshore central Palawan. (Figure 16)

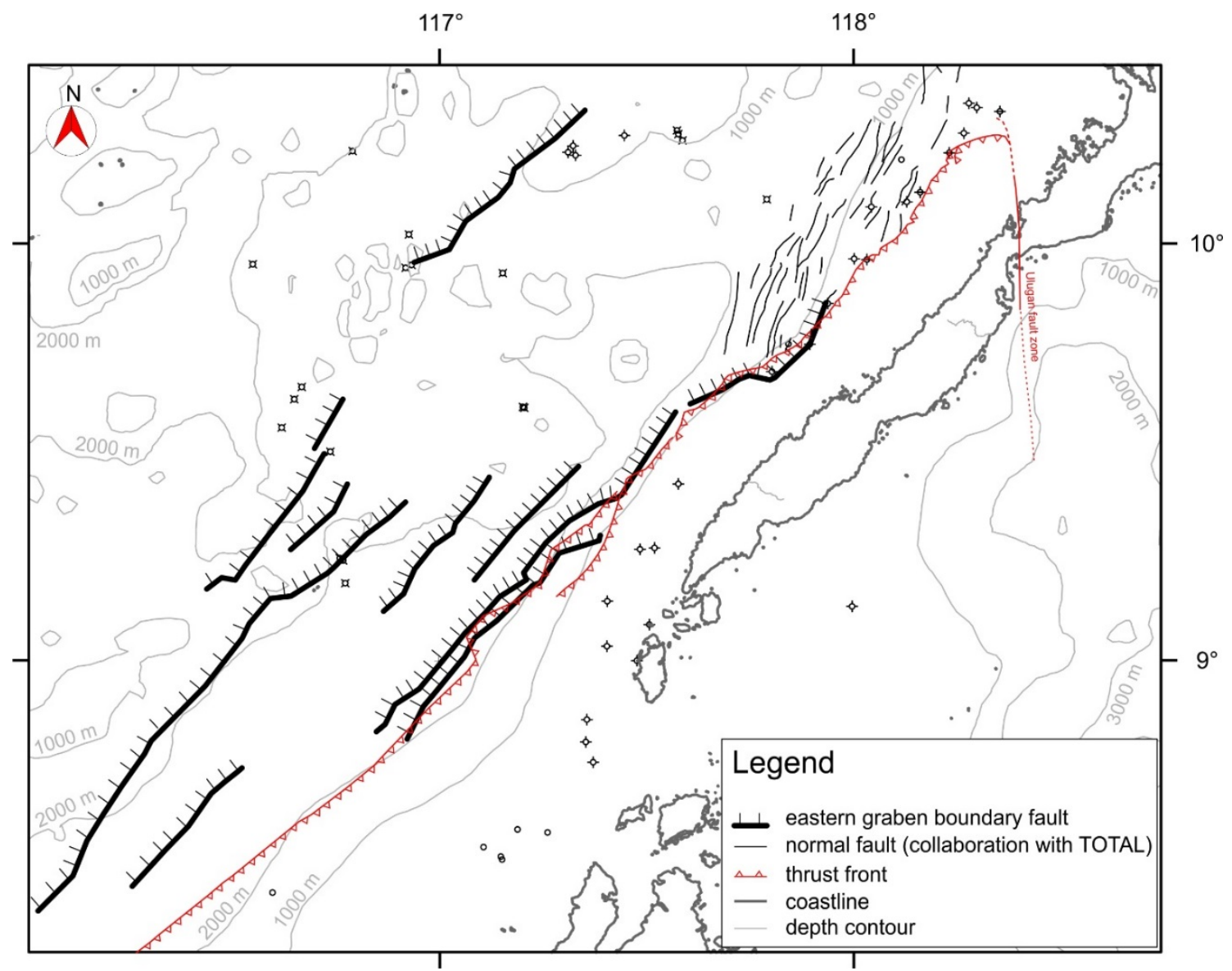

Figure 16: Map of the interpreted main fault system offshore SW Palawan. Coastline, wells and depth contours are shown for orientation.

Strike-slip faults are not so common and could only be interpreted in a few profiles. Due to the above mentioned sparse density of lines, these faults could not be traced across two or more lines. So they are not displayed in the map. Unfortunately the Ulugan fault zone, which is thought to represent a large strike-slip fault and was closely investigated onshore Palawan (Figure 17), could not be identified in the offshore seismic data. Nevertheless the offshore direction of this fault zone can be deduced at least for some kilometers from the bathymetry (dotted line in Figure 16 and Figure 17). 


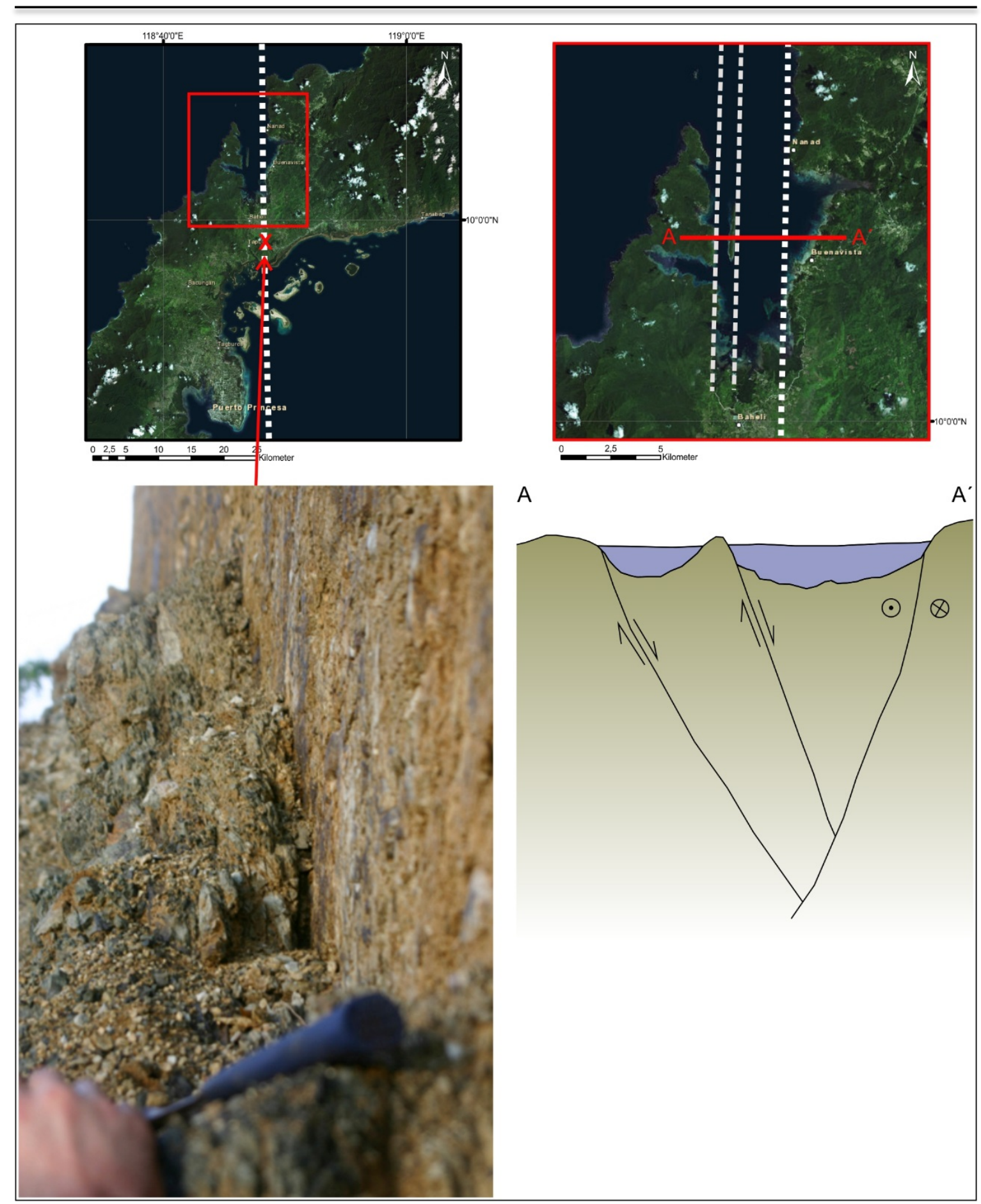

Figure 17: Ulugan Fault Zone. Top left: Satellite image (Google Earth) of Central Palawan and Ulugan Bay with the inferred position of the fault (dotted line). Top right: Satellite image (Google Earth) of Ulugan Bay. Two side-branches of the fault could be deduced from the position of an island within the bay and the dipping of rocks on it. Bottom left: Almost vertical fault plane of Ulugan fault at Ulugan Bay (location see top left image). Bottom right: schematic drawing (not to scale) of Ulugan Fault Zone. The normal faults will most likely feature a strong strike-slip component. 


\section{Well correlation}

\section{Data base}

Early 1985 Dr. Schlüter from BGR was able to take a look on several wells offshore W-Palawan at the Bureau of Energy Development (now Department of Energy) in Manila. He was allowed to make copies of 36 well reports and take them back to BGR. Wells of the producing oilfields Nido and Matinloc offshore NW-Palawan were not included. These copied well data (in many cases transcriptions) are classified and only for internal use at the BGR. Additional well data was provided by TOTAL for this project. So all in all well information of 132 wells and dredge sites (Kudrass et al., 1986) were available for this study. For wells, drilled by the petroleum industry, only stratigraphic logs with lithologic- and sometimes velocity information were available.

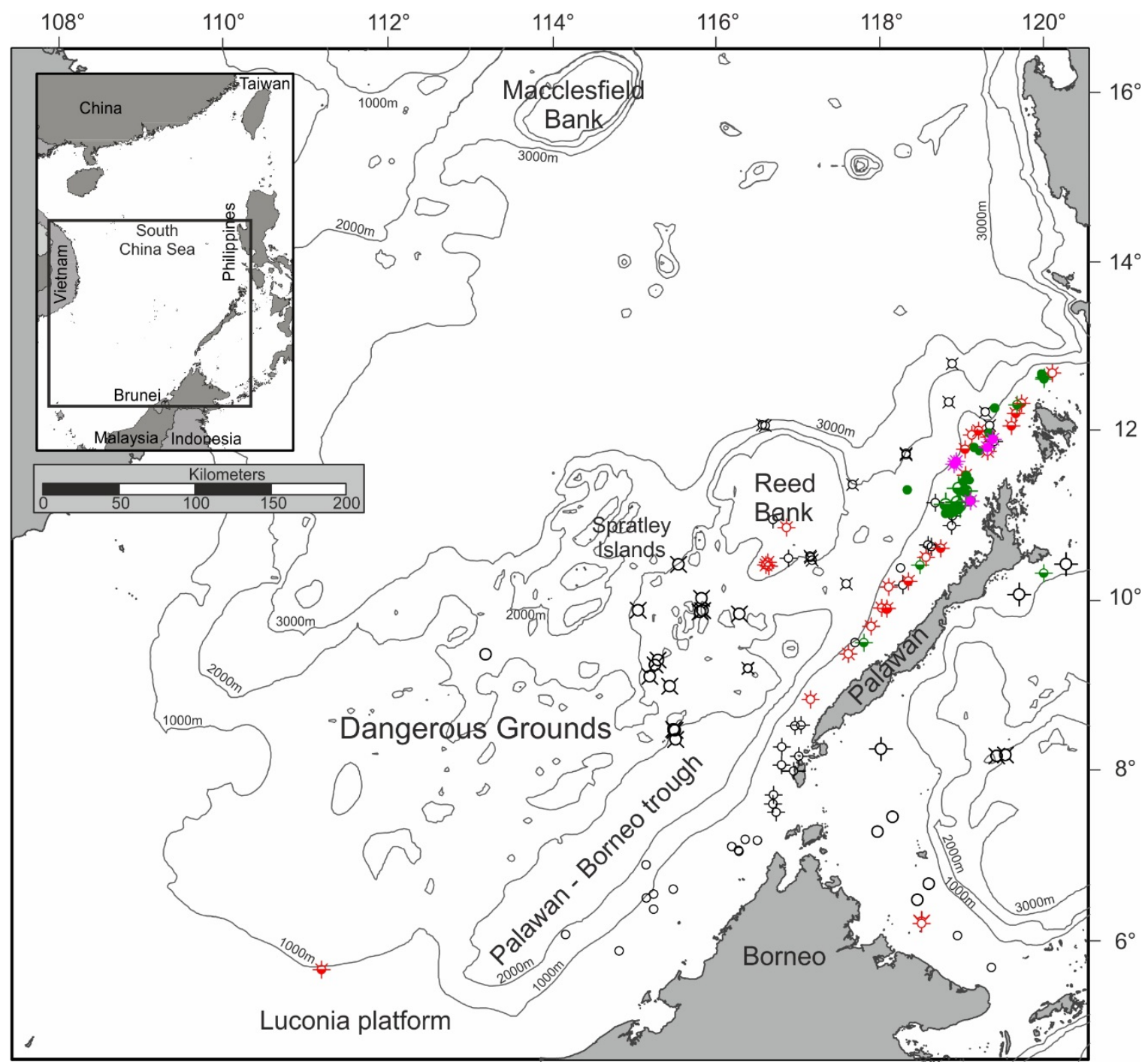

Figure 18: Overview map showing the locations of wells and dredge sites used in this investigartion.

This data set was enlarged by biostratigraphic reports, conducted by Robertson Research. These reports are a part of the data set collected by Schlüter in 1985 and are also classified for internal use only. In these reports depth intervals of planctonic foraminiferal zones are given. An example is 
given in Figure 19. The depth information of the tops of these foraminiferal zones were taken and ages were assigned to them (Figure 19 right). These ages were taken from biostratigraphic investigations of the IODP-Site 1148 in the northern South China Sea (Qianyu Li, 2004). Juxtapositions of the wells with the zone tops are given in the appendix. The dredge information was taken from Kudrass et al. (1986). Theses samples were also dated but since the exact position of the sample within a stratigraphic interval could not be specified, these dates can only give a rough estimation of the ages. See Kudass et al. (1986).

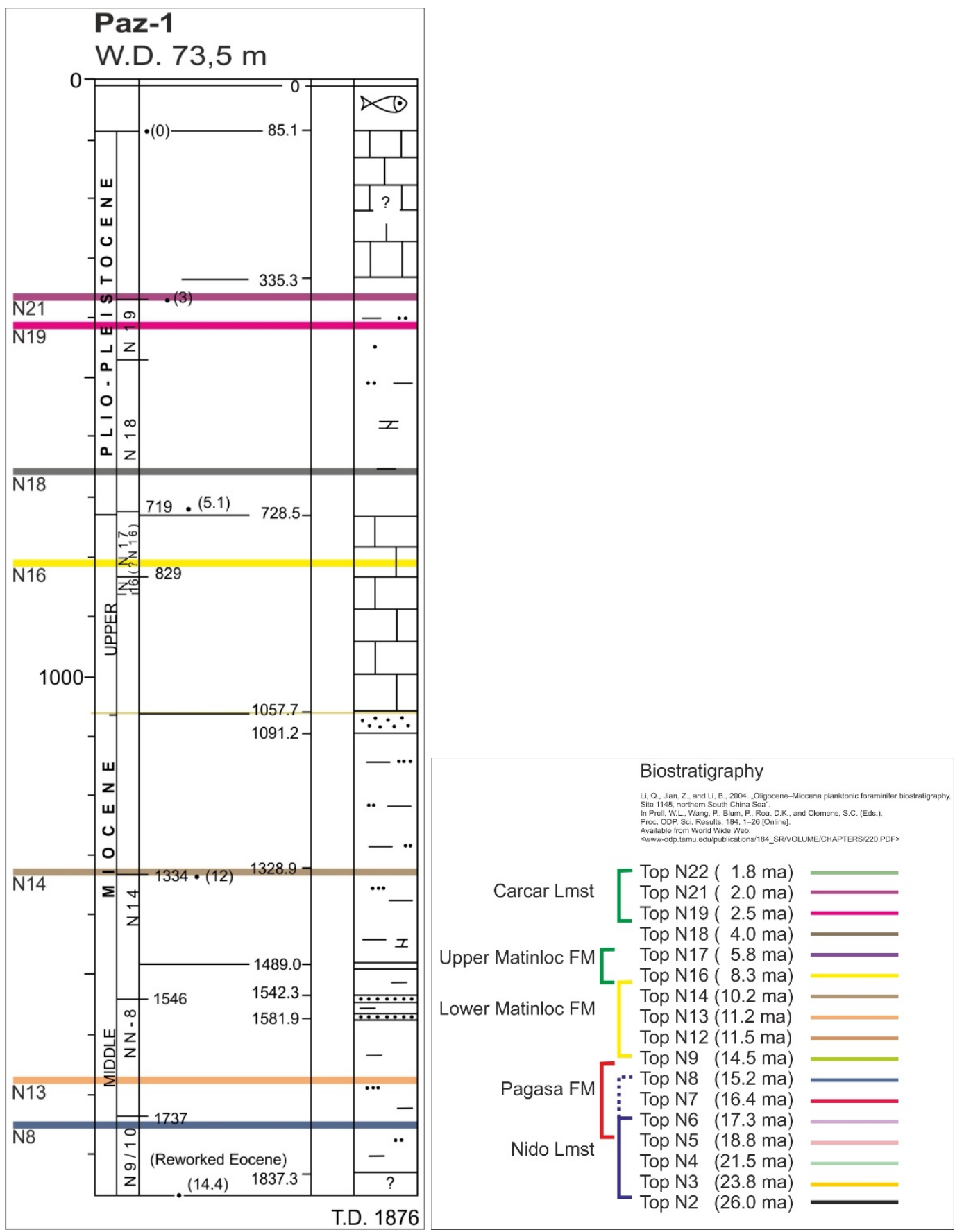

Figure 19: Re-drawn well-log of Paz-1 with biostratigraphic markers from Robertson Research (colored). Ages for zonetops are given on the right. 


\section{Biostratigraphic correlation}

Ages for the tops of foraminiferal zones were correlated with the lithologic and seismostratigraphic units from the well logs. For the correlation the investigation area was divided into three parts: The Northwest Palawan shelf, the Southwest Palawan shelf and the Sulu Sea. Wells within these parts were correlated, an example is given in Figure 20. Additionally, some selected representative wells were correlated between these parts to get the overall picture for the ages of the units.

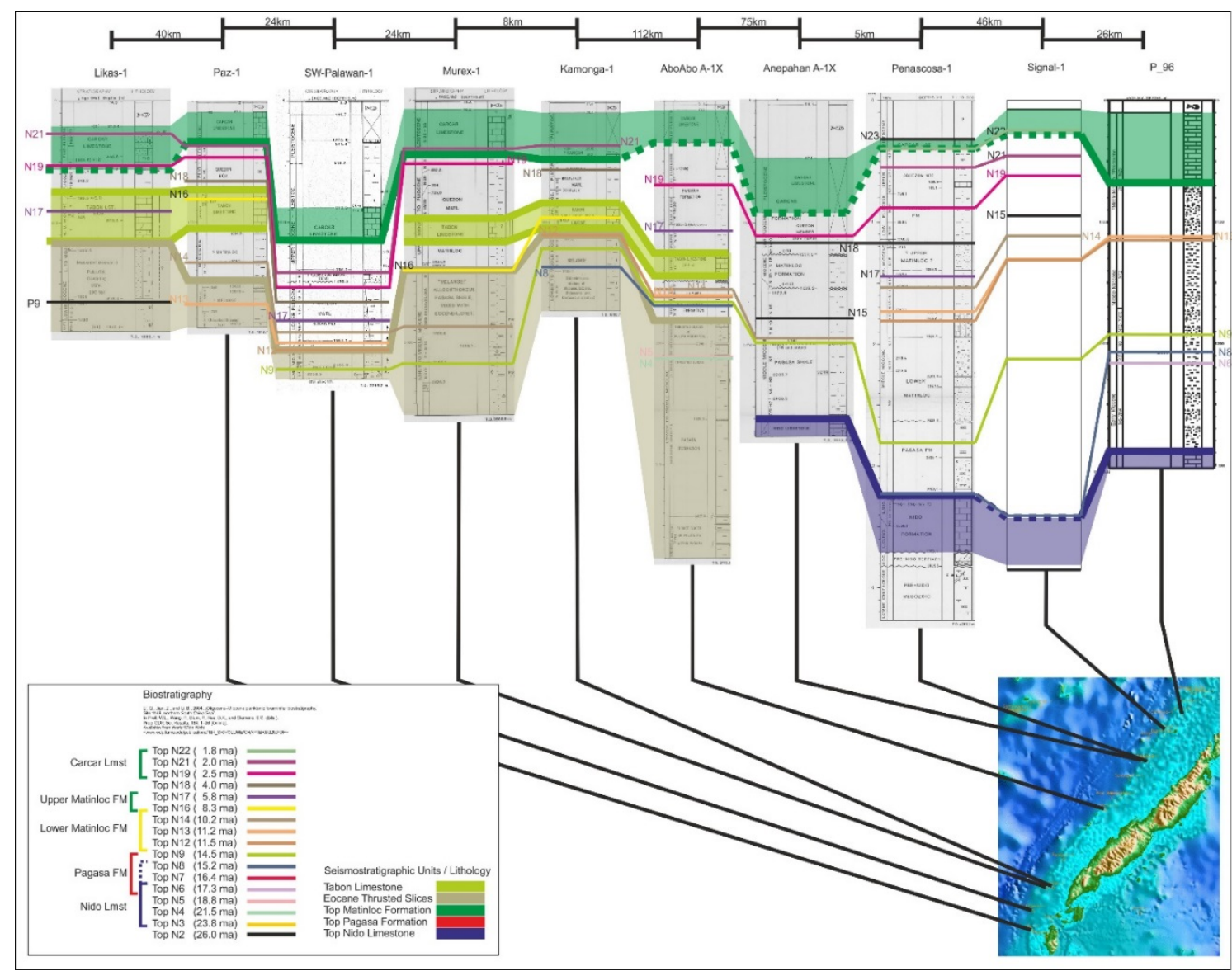

Figure 20: Well correlation across the SW-Palawan shelf

All the correlation figures are given in the appendix. 


\section{Time-depth conversion of well data}

For some wells velocity information were available. This information was restricted to static velocities, given for single stratigraphic intervals. Based upon this information a layered velocity model, using constant velocities within a layer, was developed. In a first step this velocity model was created in 1D to time-convert the well data and the depth information of the tops of foraminiferal zones. Stratigraphic markers from the well logs were also converted and a check with the seismic image showed good correlation between the top of a stratigraphic unit (e.g. the top of the carbonate platform) and a prominent seismic reflector associated with the change in lithology.

\section{Time-depth conversion of interpretation grids}

In a second step a velocity model for the W-Palawan shelf was developed. The aim of this model was to provide depth information of the Nido carbonate platform. It involved a stepwise approach via several calculated grids: The interpretation grids, thickness grids in time, velocity grids and finally thickness grids in meter. By adding the thickness grids of the overlying formations the depth grid of the Nido carbonate platform was finally created. First the outline of the interpreted Nido platform was taken as boundary. It is well defined in the north and west, but due to the lack of seismic data the southern boundary is hard to determine. The Palawan-Borneo trough extends towards the south until the West Baram Line (Cullen, 2014) and it is possible that the Nido platform is also present there, so the southern boundary for the grids was set at the West Baram Line. The eastern boundary is also unknown since seismic surveys terminate well before the coast. Nevertheless, it can be speculated that the Nido platform extends at least until the coastline and therefore the boundary was set approximately at the coastline of Palawan and Borneo. In this area a set of time grids was created based upon the interpretation of marker horizons: "Sea Bottom", "Top thrusted wedge” and "Top Nido Platform”. The grid for the sea bottom is exemplarily shown in Figure 21.

Negative values of the grids, which occurred in the "Sea Bottom" and "Top Nido Platform” grid in a small region onshore northern Palawan were set to zero to avoid inconsistent data (negative velocities).

Based upon these grids, thickness grids for water, sediment and wedge were calculated (still in time). Since the grid of the wedge is significantly smaller than the "Top Nido Platform” grid, it had to be enlarged using zero thickness outside the actual wedge distribution. 


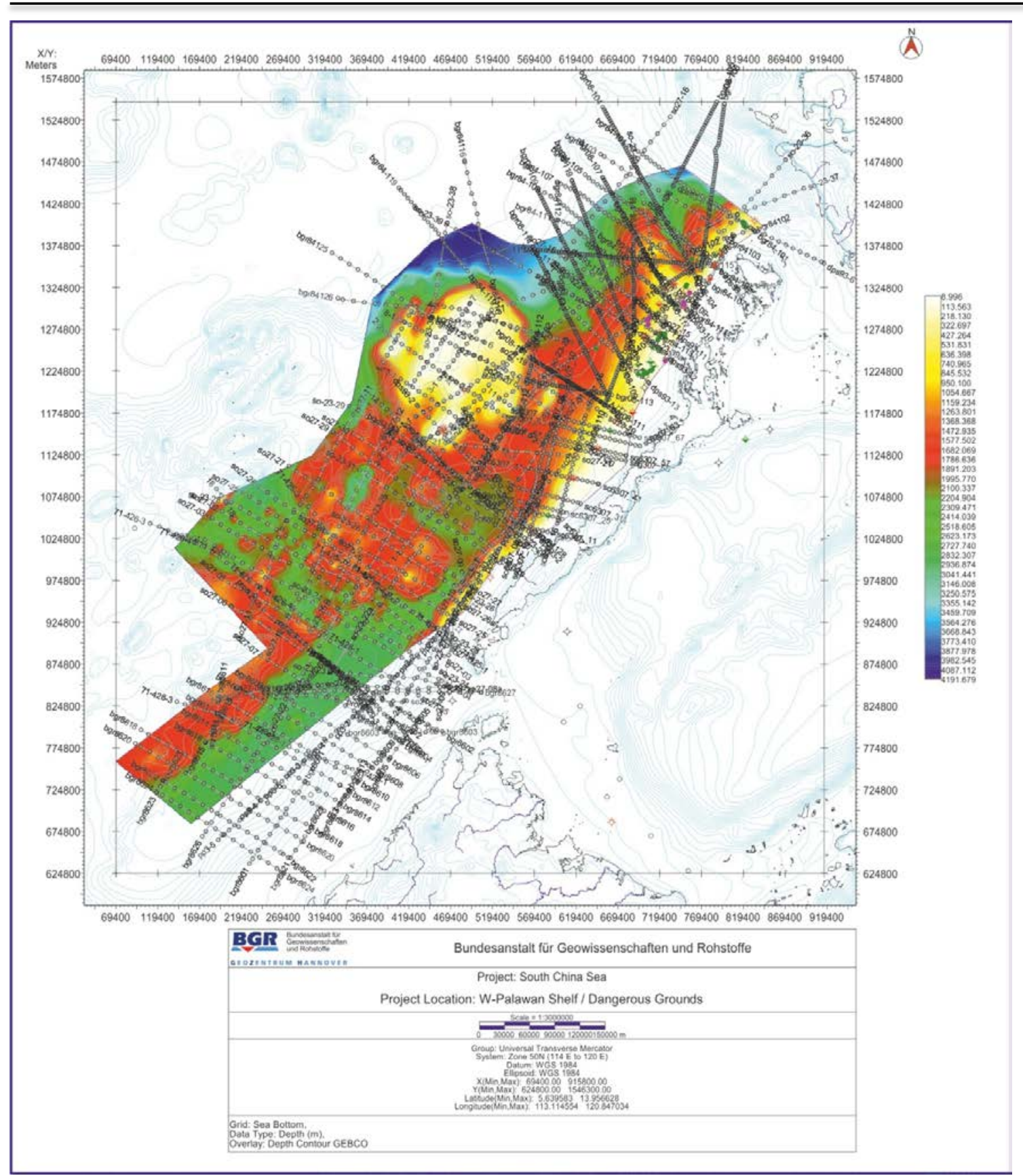

Figure 21: Gridded depth to the seafloor in seconds (TWT). Bathymetry by GEBCO shown by the blue isolines. Seismic lines are also shown.

For the calculation of the interval velocities constraints were taken from well data and published interval velocities (Franke et al., 2008). With these velocities the grids were depth converted and the results were compared with available well marker. The first approach was to use fixed velocities for the intervals. This did not lead to a good fit with the well marker. So several velocity functions with an internal velocity increase were calculated using the well velocity data and the published values as reference (Table 3). 


\begin{tabular}{|c|c|c|c|}
\hline & $\begin{array}{c}\mathrm{V} \\
\text { water }\end{array}$ & V sediments & V wedge \\
\hline fixed & $\begin{array}{l}1500 \\
\mathrm{~m} / \mathrm{s}\end{array}$ & $2400 \mathrm{~m} / \mathrm{s}$ & $3800 \mathrm{~m} / \mathrm{s}$ \\
\hline function & $\begin{array}{l}1500 \\
\mathrm{~m} / \mathrm{s}\end{array}$ & $\mathrm{V}(\mathrm{t})=0,24 *$ thickness $+1800 \mathrm{~m} / \mathrm{s}$ & $\mathrm{V}(\mathrm{t})=490 *$ thickness $+2300 \mathrm{~m} / \mathrm{s}$ \\
\hline function 1 & $\begin{array}{l}1500 \\
\mathrm{~m} / \mathrm{s}\end{array}$ & $\mathrm{V}(\mathrm{t})=0,125 *$ thickness $+1800 \mathrm{~m} / \mathrm{s}$ & $V(t)=490 *$ thickness $+2300 \mathrm{~m} / \mathrm{s}$ \\
\hline function 2 & $\begin{array}{l}1500 \\
\mathrm{~m} / \mathrm{s}\end{array}$ & $\mathrm{V}(\mathrm{t})=0,5 *$ thickness $+1800 \mathrm{~m} / \mathrm{s}$ & $\mathrm{V}(\mathrm{t})=490 *$ thickness $+2300 \mathrm{~m} / \mathrm{s}$ \\
\hline function 3 & $\begin{array}{l}1500 \\
\mathrm{~m} / \mathrm{s}\end{array}$ & $\begin{array}{l}V(t)=0,75 * \text { thickness }+1800 \mathrm{~m} / \mathrm{s} \\
V(\max )=3000 \mathrm{~m} / \mathrm{s}\end{array}$ & $V(t)=0,2 *$ thickness $+3000 \mathrm{~m} / \mathrm{s}$ \\
\hline
\end{tabular}

Table 3: Velocity functions

The last velocity function (function 3) revealed the best fit of the grids with the welltops and led to reasonable interval velocities. In two deep troughs on top of the thrusted wedge the sediments reach very high thicknesses and according to that velocity law unusual high velocities. In these troughs the velocity was limited to a maximum value of $3000 \mathrm{~m} / \mathrm{s}$. The transition from the sediments on top of the thrusted wedge to the wedge itself is marked as a positive reflection in the seismic image. This means an increase in the velocity of the sound wave. Because of the velocity law of the wedge starting slightly faster than $3000 \mathrm{~m} / \mathrm{s}$ the velocity within the sediments must be less than that. So a $\mathrm{v}(\max )$ of $3000 \mathrm{~m} / \mathrm{s}$ is plausible.

Based on velocity function 3 of Table 3 velocity grids for the internal velocity at the base of the sediments and the wedge were calculated (Figure 22 and Figure 23). 


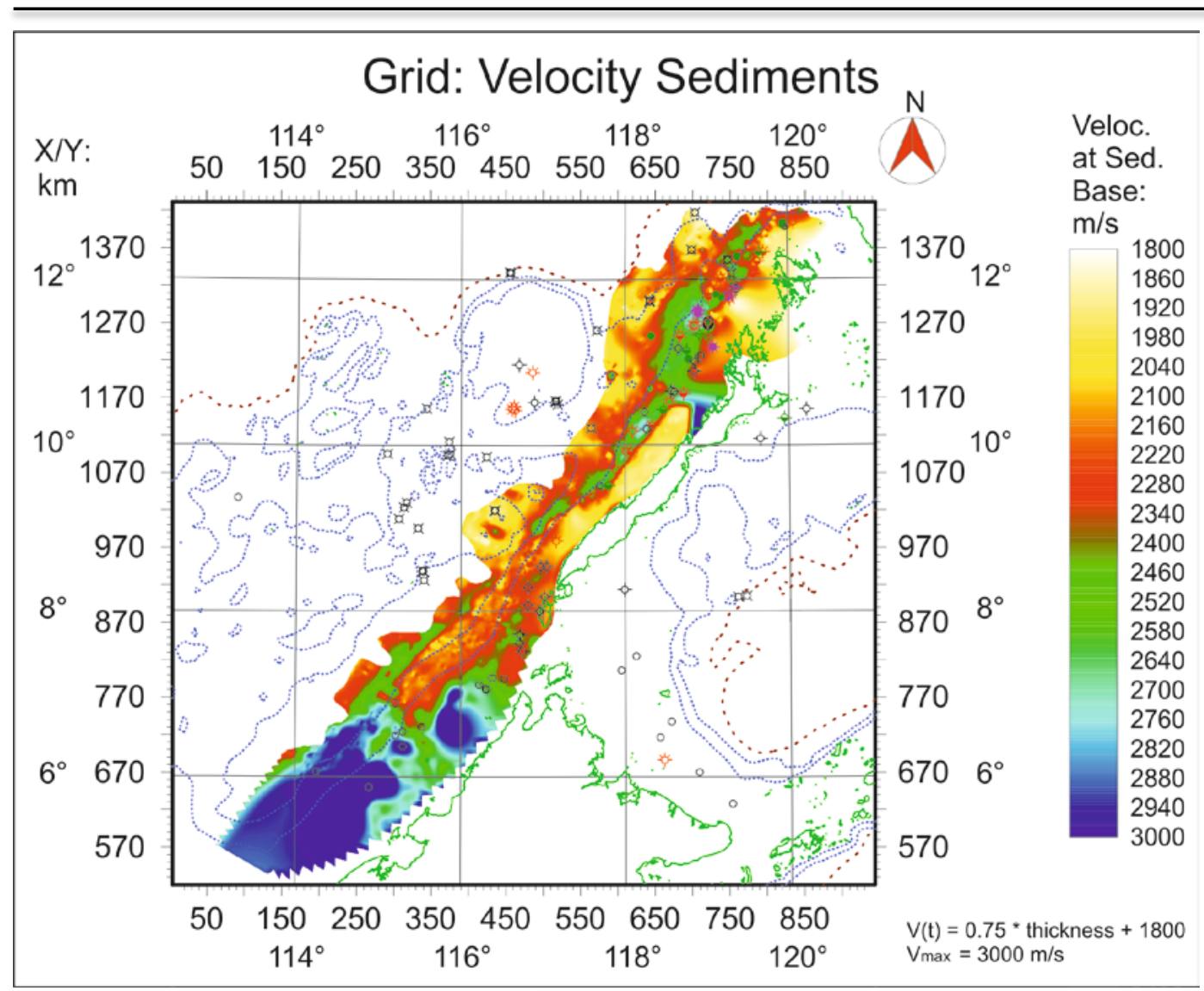

Figure 22: Velocity grid for the sediments

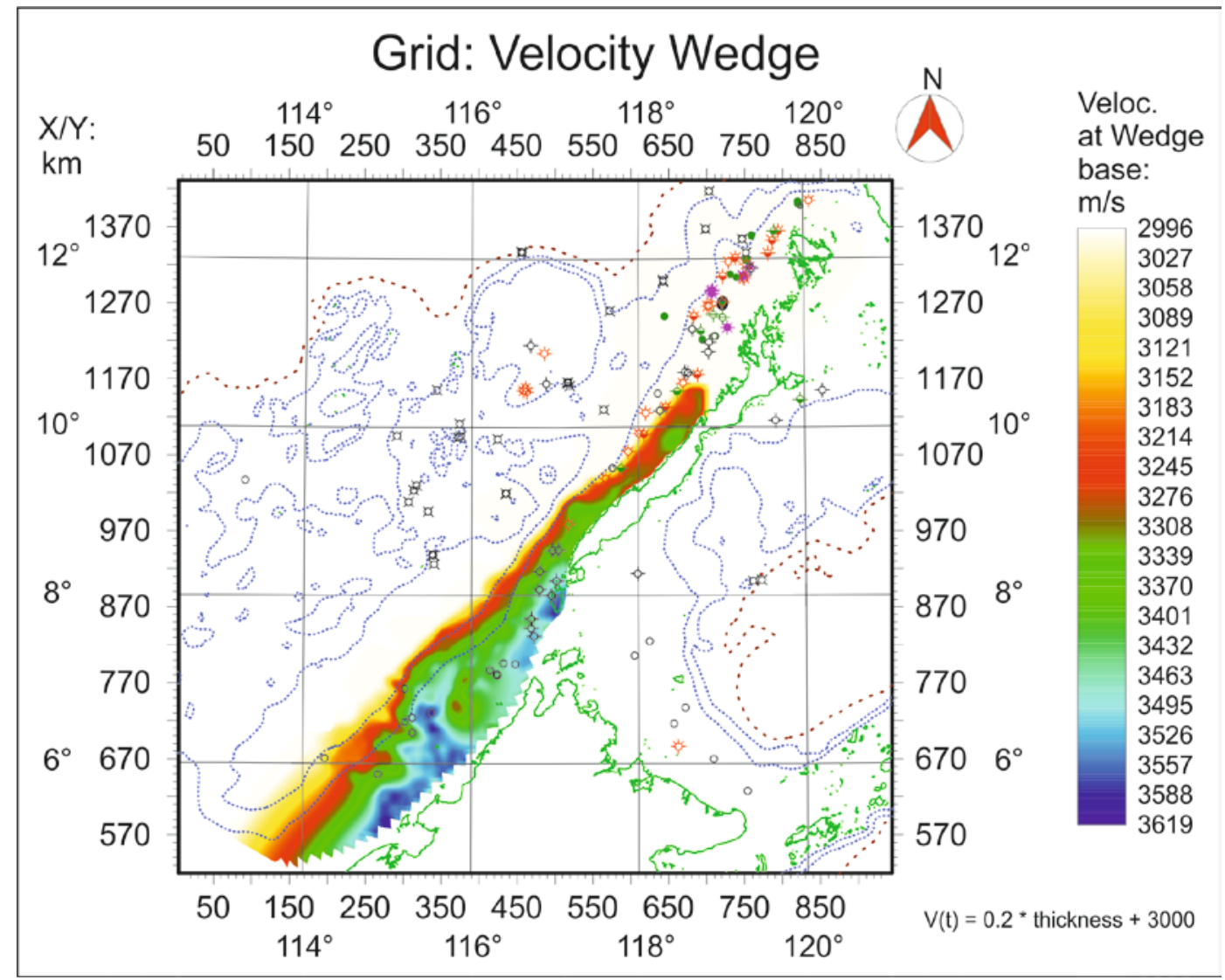

Figure 23: Velocity grid for the thrusted wedge. 
In a final step thickness grids (in meter) for the sediments and the wedge were created. The depth grid of the Nido platform (Figure 24) was calculated by summing up the thickness grids for water, sediment and wedge.

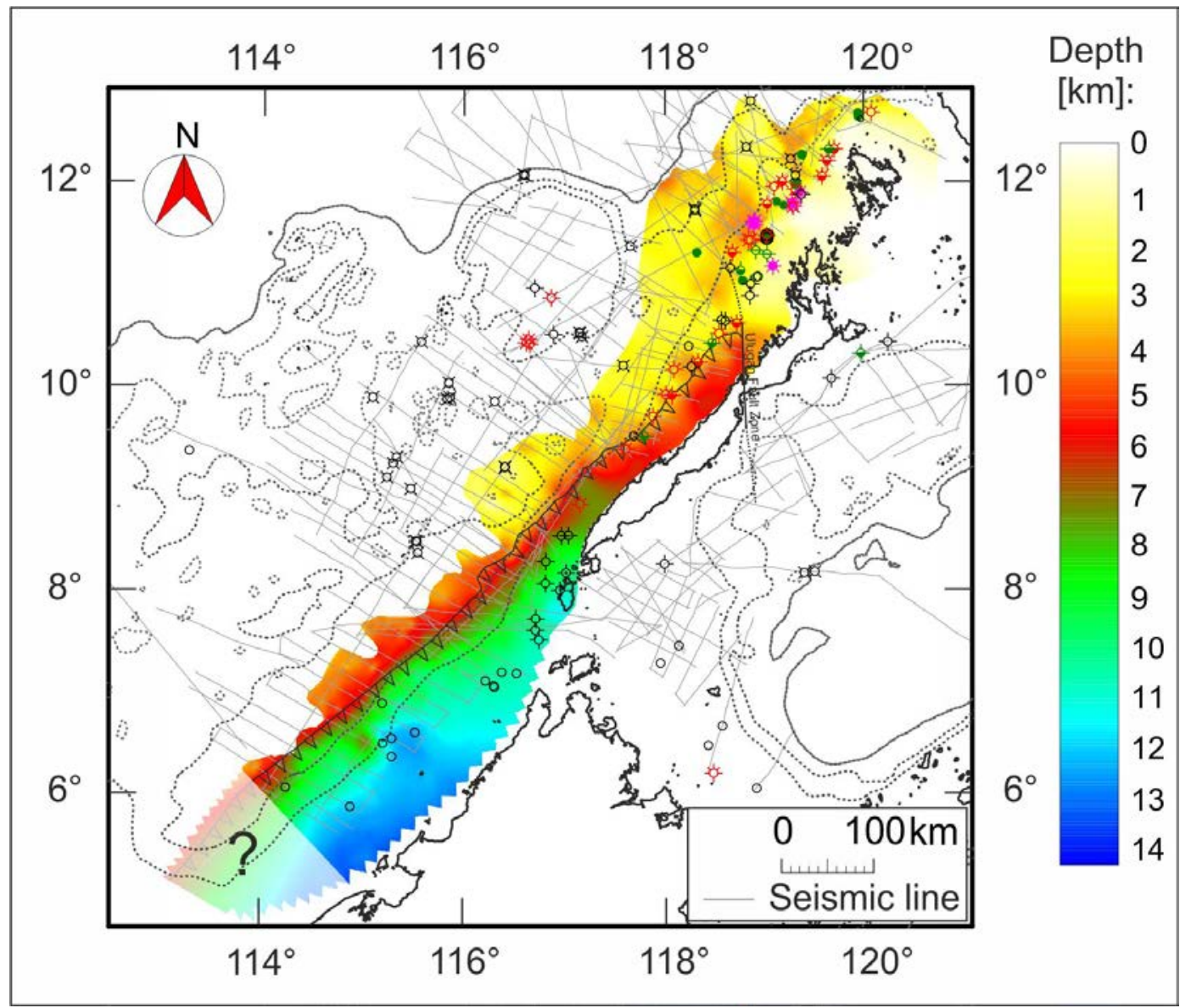

Figure 24: Depth grid for the top of the Nido Platform. 


\section{Chapter 3: Oligocene-Miocene carbonates and their role for constraining the rifting and collision history of the Dangerous Grounds, South China Sea}

Stephan Steuera, ${ }^{*}$, Dieter Frankea, Florian Meresseb, Dimitri Savvab, Manuel Pubellierb, Jean-Luc Auxietrec

aFederal Institute for Geosciences and Natural Resources BGR, Stilleweg 2, 30655 Hannover, Germany

¿Ècole Normale Supérieure ENS, 24 Rue Lhomond, 75231 Paris Cedex 5, France

‘Total E\&P Exploration, 2 Place Jean Millier, 92078 Paris La Défense Cedex, France

\section{Abstract}

The attenuated continental crust of the Dangerous Grounds is located in the southeastern part of the South China Sea. It was affected by unconformities as identified by several authors (Cullen et al., 2010; Hinz and Schlüter, 1985; Hutchison, 2010; Hutchison and Vijayan, 2010). In the northeastern Dangerous Grounds, a prominent reflector in seismic data is associated with the top of a widespread Oligocene to Early Miocene (18-20 Ma) carbonate platform. This reflector and the underlying carbonates can be used to constrain the timing of the unconformities and the rifting history of the Dangerous Grounds. By carefully interpreting seismic reflection lines we trace the platform carbonates based upon their appearance in the seismic image. This platform is continuous in the Palawan-Borneo trough and gets patchy toward the Dangerous Grounds. In the Dangerous Grounds the image of this key reflector changes and here it merely forms the top of a clastic layer. Carbonates remain abundant but mainly as isolated reefs that grew on top of tilted fault blocks. In the southwestern Dangerous Grounds the prominent unconformity sealing the tectonic activity is known as the Middle Miocene Unconformity. This in fact is an Early Miocene unconformity, which represents a sequence boundary in the Borneo Palawan trough and in various parts of the Dangerous Grounds, while in other parts of the Dangerous Grounds, it represents a major angular unconformity. The unconformity characteristics supplemented with tentative ages indicate that Luconia and the southern Dangerous Grounds were sub-aerial during the Early Miocene, while the Reed Bank, the northern Dangerous Grounds and parts of the central Dangerous Grounds were mostly submerged except for some islands concentrated on the western edge of the Borneo-Palawan trough. This trough is interpreted as a foreland basin where the flexural forebulge provided shallow marine conditions that promoted reef growth. As the carbonate deposition migrated from the Borneo Palawan trough toward the Dangerous Grounds we suggest that the flexural forebulge provided shallow water conditions for further reef growth on the eastern Dangerous Grounds. 


\section{Introduction}

The southern margin of the South China Sea remains lightly explored despite the numerous oil and gas discoveries made in the shallow water areas around the basin. The southeastern margin underwent several tectonic phases. It was strongly rifted up to the breakup of the SW-subbasin of the South China Sea and its eastern part collided and was partly overthrusted by what is now Palawan Island and Borneo. A prominent unconformity, sealing the extensional tectonic activity in the southern part of the Dangerous Grounds is traceable over large parts of the southern and western Dangerous Grounds. We could correlate this unconformity with the "Red" unconformity (RU) named by Hinz and Schlüter (1985) for the northern part of the Dangerous Grounds, keeping in mind that offshore west Palawan this unconformity no longer represents the breakup unconformity. This unconformity is interpreted by many authors to represent the Middle Miocene Unconformity (MMU). But, as Hutchison (2010) revealed, the MMU turns out to be a complex of Early to Middle Miocene events and the MMU may turn into a conformity at some places. We therefore summarize this set of Early to Middle Miocene events as "Red" unconformity (RU). A prominent seismic reflector is associated with the top of a widespread Oligocene to Lower Miocene carbonate platform, particularly in the northeastern Dangerous Grounds. The development and demise of carbonate deposition provide good constraints on the paleo-environment and the paleo-water depths since they only develop in shallow water with little or no clastic input (Bosence, 2005). These platform carbonates are sealing the extensional structures similar to the RU. In the Dangerous Grounds area carbonates are mainly isolated reefs, growing on top of tilted fault blocks. So by carefully dating these carbonates it is possible to further constrain the tectonic development of the Dangerous Grounds.

With this article we address the following questions:

1. How far to the southwest were the platform carbonates deposited across the Dangerous Grounds? 2. How can we explain the evolution from an Oligocene/Miocene carbonate platform to an erosional unconformity at the same stratigraphic position (Middle Miocene)?

3. What are the implications on our understanding of the evolution of the Dangerous Grounds Basin?

Here we discuss the timing and the origin of the observed transition from an unconformity, indicating a major hiatus, to an Oligocene-Early Miocene carbonate platform deposited in shallow water. The influence of the continental collision zone to the east, which is manifest in Borneo and Palawan, is considered. Underpinned by the interpretation of seismic lines and industrial wells, an evolution scenario for the Dangerous Grounds and its tectonic evolution in the key episode from the Oligocene to the Pliocene is derived. 


\section{Geological Setting}

The strongly attenuated continental crust, forming the southeastern margin of the South China Sea is known as Dangerous Grounds (e.g. Holloway (1982)). The Dangerous Grounds are bound to the Reed Bank block in the north, Palawan and Borneo Islands in the east, the Luconia platform in the south and the oceanic basin of the South China Sea in the northwest (Figure 25). They stretch over $750 \mathrm{~km}$ in NE-SW-direction and $400 \mathrm{~km}$ in NW-SE-direction. The overall area of our investigations can be divided into four specific regions.

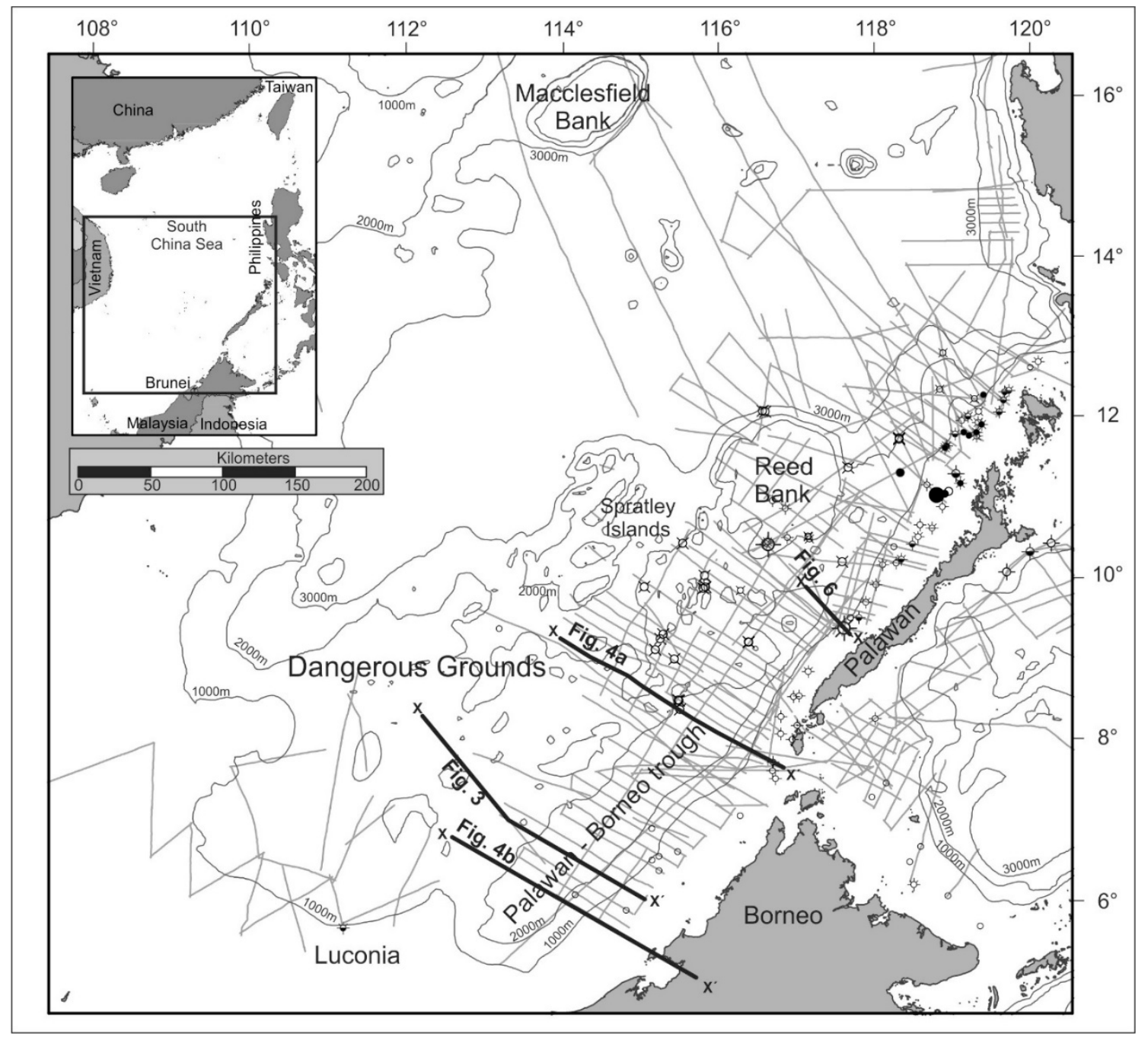

Figure 25: The southeastern South China Sea with depth contours indicated in $1000 \mathrm{~m}$ spacing. The continent -ocean transition is approximately located at the $3000 \mathrm{~m}$ contour. Positions of the seismic reflection lines, wells and dredge sites are shown. The data set comprises about 30,000 km of 2D multichannel seismic lines, 110 wells and 30 dredge sites. Seismic lines, presented in this article, are marked by a bold line. The symbols of wells mentioned in other figures are shown enlarged. 


\section{Oceanic basin}

In the Early Oligocene crustal extension reached a point where oceanic spreading initiated and the formation of the deep sea basin of the central South China Sea began. Since no deep sea boreholes exist in this basin that penetrated the igneous oceanic crust, the identification of seafloor spreading anomalies in magnetic data provides the most important constraint on the age of the seafloor. The seafloor spreading history of the South China Sea has been interpreted in different ways in the past and the debate over the correct timing of the major tectonic events is still ongoing. Most authors agree on a decreasing age of the oceanic crust toward the southwest. The timing of seafloor spreading in the central South China Sea has been revised to 31-20.5 Ma by Barckhausen and Roeser (2004) and Barckhausen et al. (2014) and from 32 to 15.5 Ma (Briais et al., 1993; Taylor and Hayes, 1983). The southwest subbasin of the South China Sea that bounds the Dangerous Grounds to the northwest opened only at about $25 \mathrm{Ma}$.

\section{Stretched continental crust}

The Dangerous Grounds crustal architecture as interpreted from geophysical data and occasionally dredge samples indicates that the area is underlain by highly attenuated continental crust (Clift et al., 2008; Ding et al., 2013; Hutchison and Vijayan, 2010; Schlüter et al., 1996). Gravity modeling revealed crustal thicknesses between 14 and $19 \mathrm{~km}$ (Braitenberg et al., 2006). It is widely accepted that the Dangerous Grounds rifted away from mainland China in the Eocene. Rifting on the protoChina continental margin is believed to have started in the latest Cretaceous-Early Paleocene (Ru and Pigott, 1986; Taylor and Hayes, 1980; Zhou et al., 2009) and led to a series of (half-) grabens filled with Paleogene continental to shallow marine deposits (Taylor and Hayes, 1980, 1983). Due to a relatively low sedimentation rate in comparison with the northern margin (Clift et al., 2008), the tectonic framework of rift structures in the Dangerous Grounds is still recognizable in the bathymetry.

\section{Collision zone with Borneo and Palawan}

In the southeast the Dangerous Grounds are bound to Borneo Island. The Crocker-Rajang mountain belt extends along the central part of Borneo, from Sabah to central-south Sarawak, and likely formed as an accretionary complex during south- or southeastdirected subduction of an oceanic basin (Berggren, 1995; Hall, 2002; Hutchison, 2005b; Pubellier et al., 2003; Rangin, 1991). The passage from subduction to collision divides the Crocker-Rajang mountain belt into two main units: the Rajang (Eocene)-Crocker (Oligocene-Lower Miocene) Wedge and the Frontal (Middle Miocene to Pleistocene) Wedge (Sapin et al., 2011) that continues also into the shallow offshore area (Levell, 1987). They are separated by a widespread regional unconformity, the Deep Regional Unconformity (DRU) or Sabah Orogeny ( 16 Ma). 
The formation of the accretionary wedge offshore south and central Palawan is constrained by the underlying and overlying carbonate formations (Steuer et al., 2013). The formation of this wedge must have occurred after the formation of the carbonatic sequences underneath (Nido-) and must have ended before the overlying and sealing Tabon Limestone was deposited. Biostratigraphic correlation gives an Early Miocene age of 18-20 Ma for the top of the Nido platform carbonates. Steuer et al. (2013) thus concluded that the wedge was not present before 18 Ma because some time interval is necessary for the platform carbonates to subside to their present depth. The Tabon Limestone seals the wedge and was therefore deposited after the formation of the wedge. Onshore the oldest Tabon Limestones is about 16 Ma old (late Early Miocene) and the youngest is 10.8 Ma (Rehm, 2002). The formation of the wedge thus started between 18 and 16 Ma ago and continued migrating northwest until the upper Late Miocene ( $7 \mathrm{Ma})$.

\section{Palawan Borneo trough, the foredeep}

The attenuated continental crust of the Dangerous Grounds was overthrusted by the CrockerPalawan accretionary wedge from the southeast. The load of this wedge drove tectonic subsidence in the Palawan-Borneo trough which is interpreted as flexural foreland basin (Milsom et al., 1997). Presently the Palawan - Borneo Trough marks the eastern edge of the Dangerous Grounds but the rifted continental crust of the Dangerous Grounds continues underneath the trough and likely partly underneath the accretionary wedges of Borneo and Palawan (e.g. Cullen et al., (2010); Franke et al., (2008); Hinz and Schlüter, (1985); Hutchison and Vijayan, (2010); Steuer et al., (2013)). Possibly it extends as far east to the onshore beneath Mt. Kinabalu (Cottam et al., 2010).

\section{Data and interpretation}

Between the years 1983 and 2008 the Federal Institute for Geosciences and Natural Resources (BGR) acquired a set of 2D MCS seismic lines across the Dangerous Grounds. This data set was extended by seismic lines shot by the petroleum industry. All together $\sim 30,000 \mathrm{~km}$ of seismic lines covering an area of $150,000 \mathrm{~km}^{2}$ from $6^{\circ} \mathrm{N}$ to $11^{\circ} \mathrm{N}$ and $113^{\circ} \mathrm{E}$ to $117.5^{\circ} \mathrm{E}$ were available for this study. The location of the seismic lines is given in Figure 25. In addition, well logs and biostratigraphic information of 30 wells, drilled by the petroleum industry since 1970 and 30 dredge samples by Kudrass et al. (1986) were used. The position of the wells and dredge sites is also given in Figure 25. The interpretation of seismic lines is constrained by correlating the interpreted unconformities with the information of several dredge samples and the age information collected by an IODP-well (Shipboard Scientific Party, 2000). An overview of the main lithologies and unconformities interpreted in the Dangerous Grounds and the Palawan-Borneo wedge is given in Figure 26. 


\section{Major unconformities}

\section{The deep regional unconformity (DRU)}

The DRU is located within the accretionary wedge of Borneo. Clift et al. (2008) suggested that this DRU ( 16 Ma) is an equivalent of a 'Middle Miocene' unconformity, a view that is shared by Hall and Morley (2004), who suggested a 16-17 Ma syn-rift to drift unconformity (Breakup Unconformity BU) at the same stratigraphic position. However, Cullen (2010) proposed that the Deep Regional Unconformity is associated with tilting and uplift of the Sabah margin and is a quite local feature (Levell, 1987). This author suggested it as inappropriate to consider correlating the MMU with the Deep Regional Unconformity.

\section{The South China Sea unconformity (SCSU)}

A strong unconformity, separating the syn-rift from the overlying post rift sediments (BU), is traceable throughout the South China Sea. Hutchison (2004) refers to this unconformity as MMU. Cullen (2010) indicates a diachronous age for the breakup unconformity in the South China Sea. He therefore rejects the name MMU as given by Hutchison (2004) and refers to this prominent unconformity, as South China Sea Unconformity (SCSU). Cullen (2010) proposed an age of 18-15.5 Ma for this unconformity. 


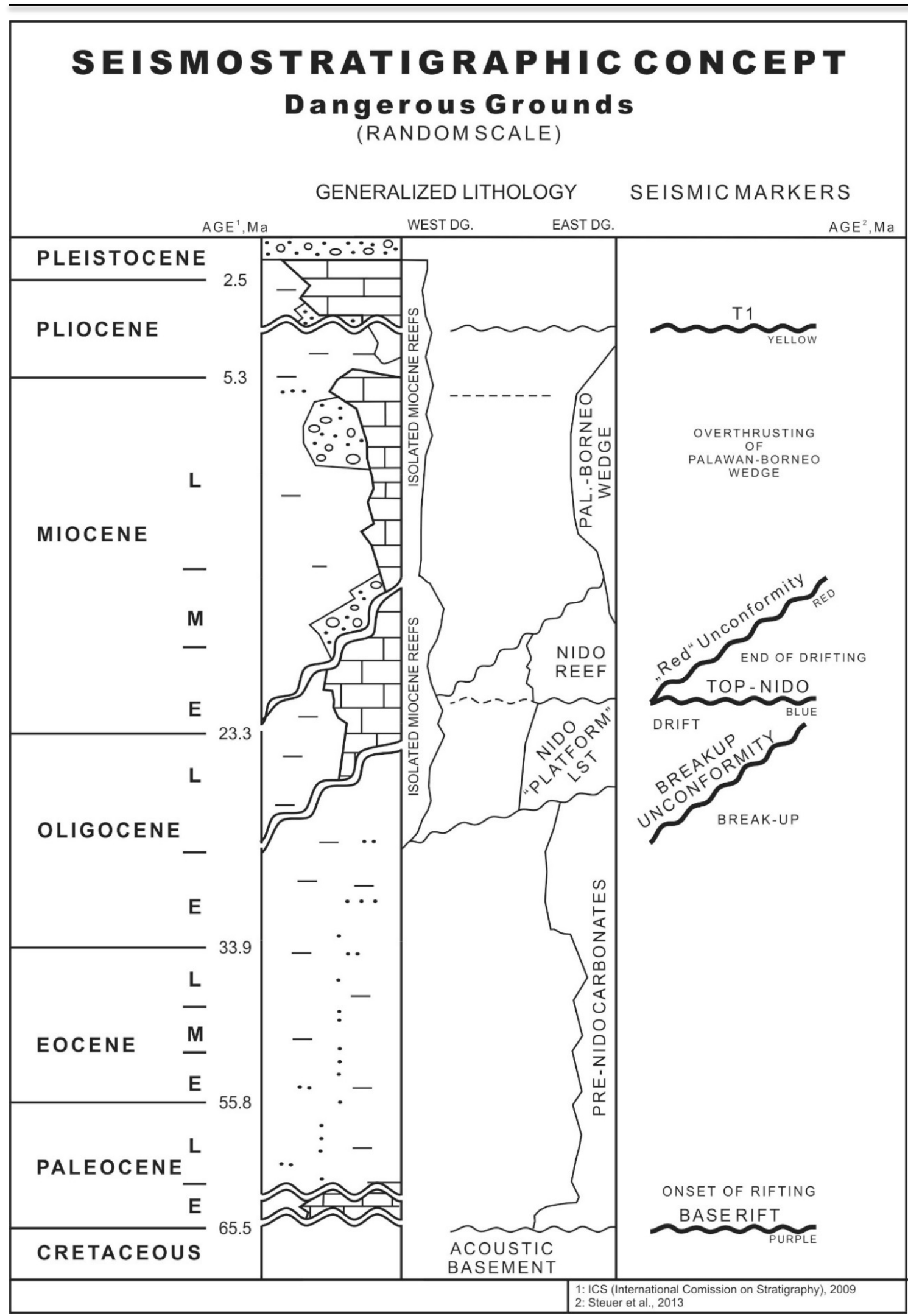

Figure 26: Generalized seismostratigraphy for the Dangerous Grounds summarized from Steuer, Franke, Vihajan, Cullen, etc... The main formations are divided into the western part and the eastern part close to the Palawan-Borneo wedge. The main unconformities (Breakup and "Red" unconformity) are time- and space-transgressive over the investigation area. Breakup of the Southwestern Subbasin of the South China Sea initiated first in the north and propagated toward the southwest. The Breakup unconformity follows this direction. The Top Nido unconformity is a seismic horizon caused by the velocity increase at the top of a carbonate succession. 


\section{The "MMU" and the "Red" unconformity}

In the southwestern Dangerous Grounds the most prominent unconformity, sealing the syn-rift deposits, has been given several names. By Hinz and Schlüter (1985) it was introduced as "Blue*” unconformity in the northeastern Dangerous Grounds (West Palawan shelf). Hutchison (2004) introduced the most prominent unconformity between underlying rifted terrane and overlying postrift draping strata as the Middle Miocene Unconformity (MMU). Thies et al. (2005) confirmed from drilling results in the southern area of the Dangerous Grounds the proposed age of $16 \mathrm{Ma}$ for the erosion at this unconformity that preserves much of the sedimentary section close to the Luconia Platform margin, but has eroded much of the 25 Ma to 16 Ma section further from the margin. Madon et al. (2013) identified an Early Miocene Unconformity between 19 Ma and 17 Ma in the northern Luconia province. However, Hutchison and Vijayan (2010) argue that this unconformity is rather an amalgamate of multiple Lower/Middle Miocene events. The so called Middle Miocene Unconformity, recognized as a pronounced angular unconformity throughout the deepwater Sarawak area, is in fact Early Miocene with a strontium isotope age of 18.5-19.0 Ma, with a 2.02.5 My hiatus at the unconformity (Hutchison and Vijayan, 2010). A Middle Miocene Unconformity (15.5 Ma) was introduced by Hinz and Schlüter (1985) as “Red” unconformity. This unconformity is marked by a prominent seismic reflector and can be traced over large areas in the Dangerous Grounds. In the Borneo-Palawan trough the "Red” unconformity represents rather the top of a sedimentary layer, the so called Pagasa Formation (Steuer et al., 2013), than an erosional unconformity. The Bako-1 and Mulu-1 wells, targeting noncarbonated paleo-highs, in addition reveal that this unconformity is covered by a condensed section that comprises about $10 \mathrm{My}$ (Hutchison and Vijayan, 2010). Below the "Red" unconformity a fine clastic deepwater sequence was deposited in the Borneo Palawan trough. The "Red" unconformity separates this fine clasitic sequence from coarse clastic sediments above and rather represents the top of a sedimentary unit than an erosional unconformity. It has been dated 15.2 Ma (Steuer et al., 2013). The seismic reflector representing this unconformity is used as time marker for the correlation of the other unconformities. In the following we refer to this marker as the "Red" unconformity.

\section{Correlation between Red Unconformity and the breakup unconformity}

The Red Unconformity changes its character over the area under investigation. In the northern part, offshore northwestern Palawan, it is clearly a post-rift feature. It is located above the "Nido" carbonate platform which in turn seals the rift structures. Tracing the reflector associated with this unconformity toward the southwest the sedimentary succession between the unconformities Red and Breakup decreases continuously until they coincide. Franke (2013) discussed in detail a potential breakup unconformity in the South China Sea. He concluded that, if we agree with the proposed ages of the oceanic crust as derived from the interpretations of the magnetic spreading anomalies a breakup unconformity in the South China Sea postdates the formation of earliest 
oceanic crust by about 6-8 My. However, it is evident that the breakup unconformity gets younger in SW direction following the propagating rift (Franke et al., 2014).

\section{The platform carbonates}

In the northeastern Dangerous Grounds, the Reed Bank area and NW Palawan the breakup unconformity is directly overlain by a widespread carbonate platform (Nido carbonates), which is considered as important petroleum reservoir (Williams, 1997). Offshore NW Palawan the platform carbonate formation was established in the Early Oligocene, not before the formation of the breakup unconformity at about $31 \mathrm{Ma}$ (Steuer et al., 2013). A definition about when the platform carbonates terminated is complicated by the fact that most wells drilled reefal buildups on top of the platform carbonates that locally continued growing when the deposition of the platform carbonates was ended. Steuer et al. (2013) did a careful evaluation of well reports for wells penetrating the platform carbonates and narrowed the time of last carbonate deposition by calculating sedimentation rates for the carbonates and the overlying strata. This resulted in a correction of previously given ages for the end of platform carbonate deposition from latest Oligocene times to earliest Miocene times, at 18-20 Ma (Steuer et al., 2013).

\section{Seismic facies of the platform carbonates}

A prominent stratigraphic sequence, concurrent with the Oligocene to Early Miocene seafloor spreading episode, is the Nido carbonate sequence (Figure 26, Figure 27, Figure 29). It is made up of a shallow marine carbonate platform, followed on top by limestones, wackestones, and packstones, deposited in an open marine, to shelfal setting. On the seismic data, this sequence exhibits subparallel reflections of high continuity and low frequency content (Franke et al., 2011; Steuer et al., 2013). Samples from dredging on the Dangerous Grounds, south of Reed Bank, indicate shallow marine carbonates (wacke-, pack-, boundstone) with ages ranging from Late Oligocene to lower Middle Miocene (Kudrass et al., 1986).

In the NW Palawan region the deposition of the Nido carbonates ceased with the drowning of the carbonates in the Early Miocene (Aquitanian-Burdigalian) and the carbonate buildups were sealed by Early to Middle Miocene basinal Pagasa clastics (Fournier et al., 2005; Williams, 1997). Also in the eastern Dangerous Grounds the rift structures are sealed by the "Nido" carbonates which were drilled in wells Penascosa and Aboabo offshore S-Palawan (Steuer et al., 2013). Our interpretation approach was to compare the seismic appearance of the carbonates at the drill sites with the appearance of a strong positive reflector in the Dangerous Grounds at the same stratigraphic position. We found that the strong positive reflector resulted from a sharp increase in the seismic velocities from the clastic sediments to the carbonates. 


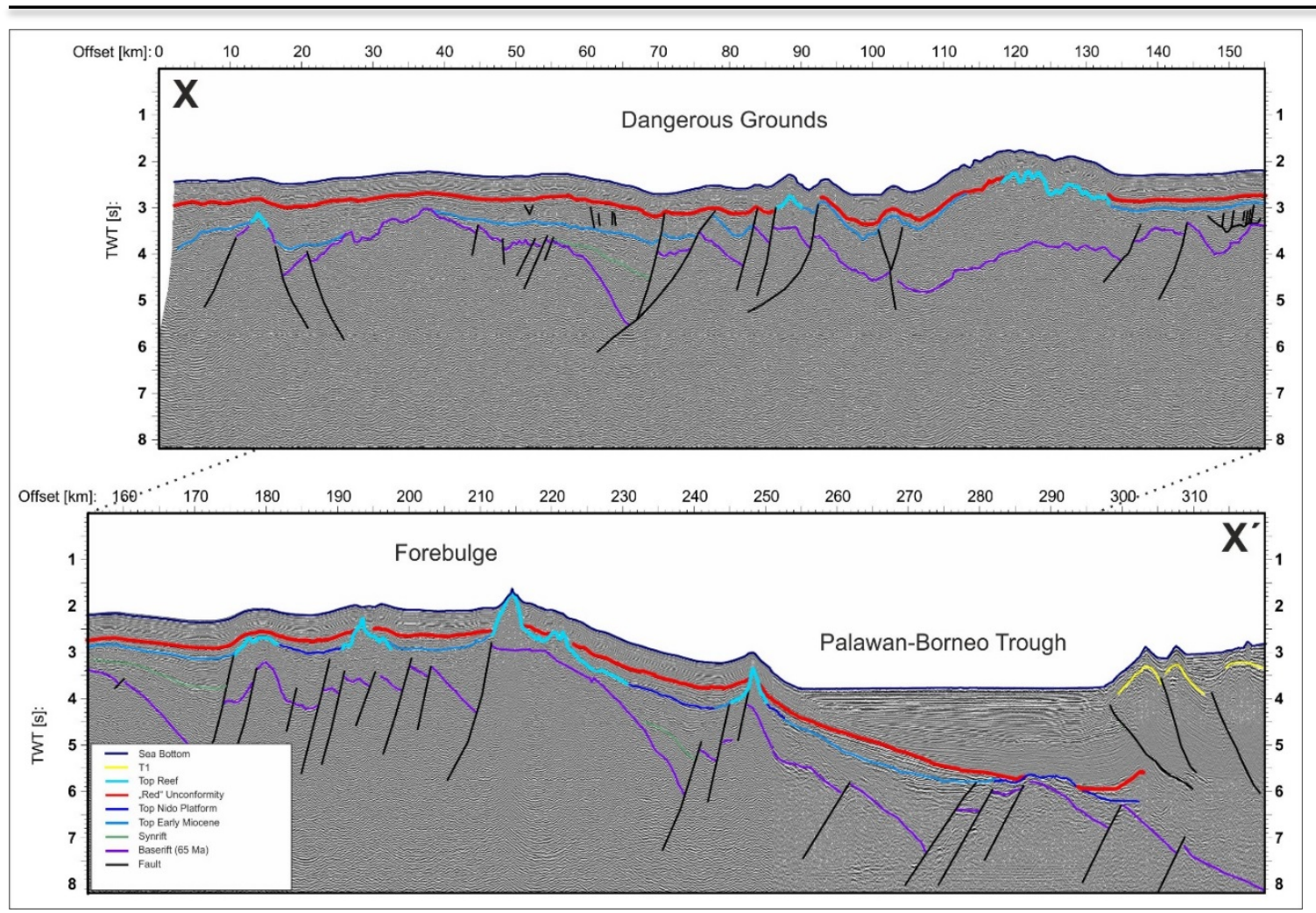

Figure 27: Seismic profile across the southern Dangerous Grounds, running from northwest (up-left) to southeast (lowright). The depth is given in two-way-time and the horizontal distance in kilometers. The profile is divided into two parts for better visibility. Distinct features from left to right are draped reefs in the Dangerous Grounds, the stronger uplifted forebulge, the Palawan-Borneo trough and the western end of the Palawan-Borneo wedge. This wedge is located on top of the downgoing rifted continental crust of the Dangerous Grounds. Reefs are marked with light blue color, also the "Red" unconformity was emphasized. Reefs that were covered by sediments prior to the "Red" unconformity are located e.g. at km 14 or at km 178. Reefs with an onlapping "Red" unconformity are located e.g. at km 194. A reef with almost no sedimentary cover is located at $\mathrm{km} 214$, but it is at a water depth that inhibits further reef development.

This reflector can be traced over wide areas. There are some criteria for interpreting a facies: Magnitude of the amplitudes of the reflector, direction (positive/negative) of the reflections, the lateral continuity of the reflection and the internal structure of the layer. Our main criterion for interpreting platform carbonates is the presence of a strong positive reflection in the seismic image that is followed by up to three additional strong positive reflections which are parallel to subparallel to the first reflection. This set of reflections typically overlies more chaotic reflections (see Figure 27 and Figure 29). The base of the carbonate platform is harder to determine it was set on a weak negative reflector that marks the change of the reflection pattern from chaotic to more stratified, which is associated with clastic sediments. Younger reef buildups can be clearly recognized from their appearance in the seismic data (Figure 29, Figure 30 and Figure 32). In western direction the positive reflection becomes weaker in the reflection seismic data and the pattern underneath indicates parallel bedding rather than the typical chaotic pattern associated with the carbonates. In this case we suggest that the sediments are more clastic-prone rather than pure carbonates but we still suggest the top of this succession is time equivalent to the top of the carbonates (Early Miocene). Tracing the reflection westward from NW Palawan it not only gets weaker but finally turns into a conformable sequence close to the oceanic basin (Schlüter et al., 1996). 


\section{Stratigraphy of reefs in the Dangerous Grounds}

Reefs are abundant in the Dangerous Grounds area and a large number of those were mapped along the seismic lines. These data were supplemented with information on the location of reefs taken from other publications (Hutchison and Vijayan, 2010; Letouzey et al., 1988), see Figure 31.

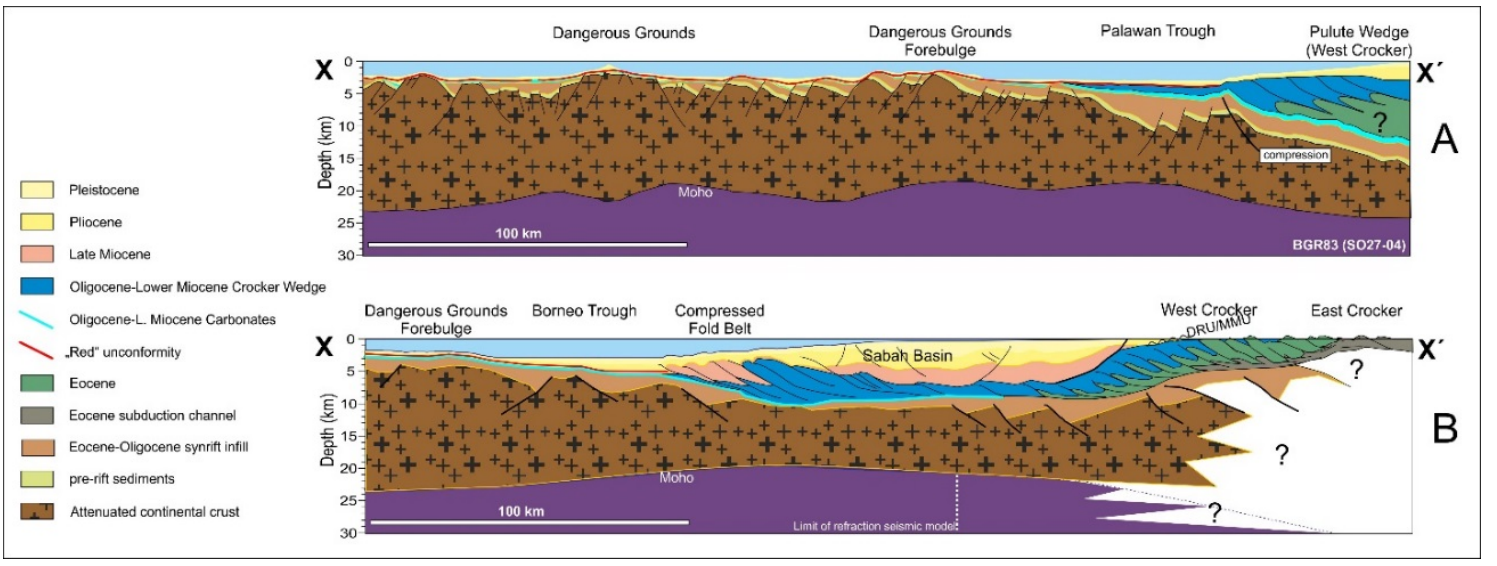

Figure 28: Two schematic crustal-scale profiles across the Dangerous Grounds in NW-SE direction. The location of the lines is given in fFigure 25. The depth of the Moho is modeled from refraction and gravity data and extrapolated in the eastern (right) part of profile $B$. The limit of available refraction data is indicated by a white vertical line. Both profiles show the rifted continental crust of the Dangerous Grounds. The "Red" unconformity, sealing the tectonics in the western (left) part is indicated. Also the Oligocene-Miocene carbonates are highlighted. The position of the foredeep and forebulge is shown. It is noticeable that the Sabah Basin in NW Borneo formed over the most attenuated part of the continental crust.

The reefs are draped by strata at different levels. Our main reference level is a distinct horizon in the Borneo-Palawan trough, which previously has been assigned an age of about $17 \mathrm{Ma}$ (Hinz and Schlüter, 1985). It corresponds to the DRU by Levell (1987), "Red” unconformity by Hinz and Schlüter (1985), or MMU by Hutchison and Vijayan (2010). From their stratigraphic position we infer that the reefs initiated on the crests of tilted fault blocks during the deposition time of the Nido carbonate platform in the Late Oligocene to Early Miocene. In some places Miocene reefs are growing on top of the Early Miocene

Unconformity, but these locations are limited to a small area in the central part of the Dangerous Grounds (Figure 28 and Figure 30). 
Chapter 3: Oligocene-Miocene Carbonates and their role for constraining the rifting and collision history of the Dangerous Grounds, South China Sea

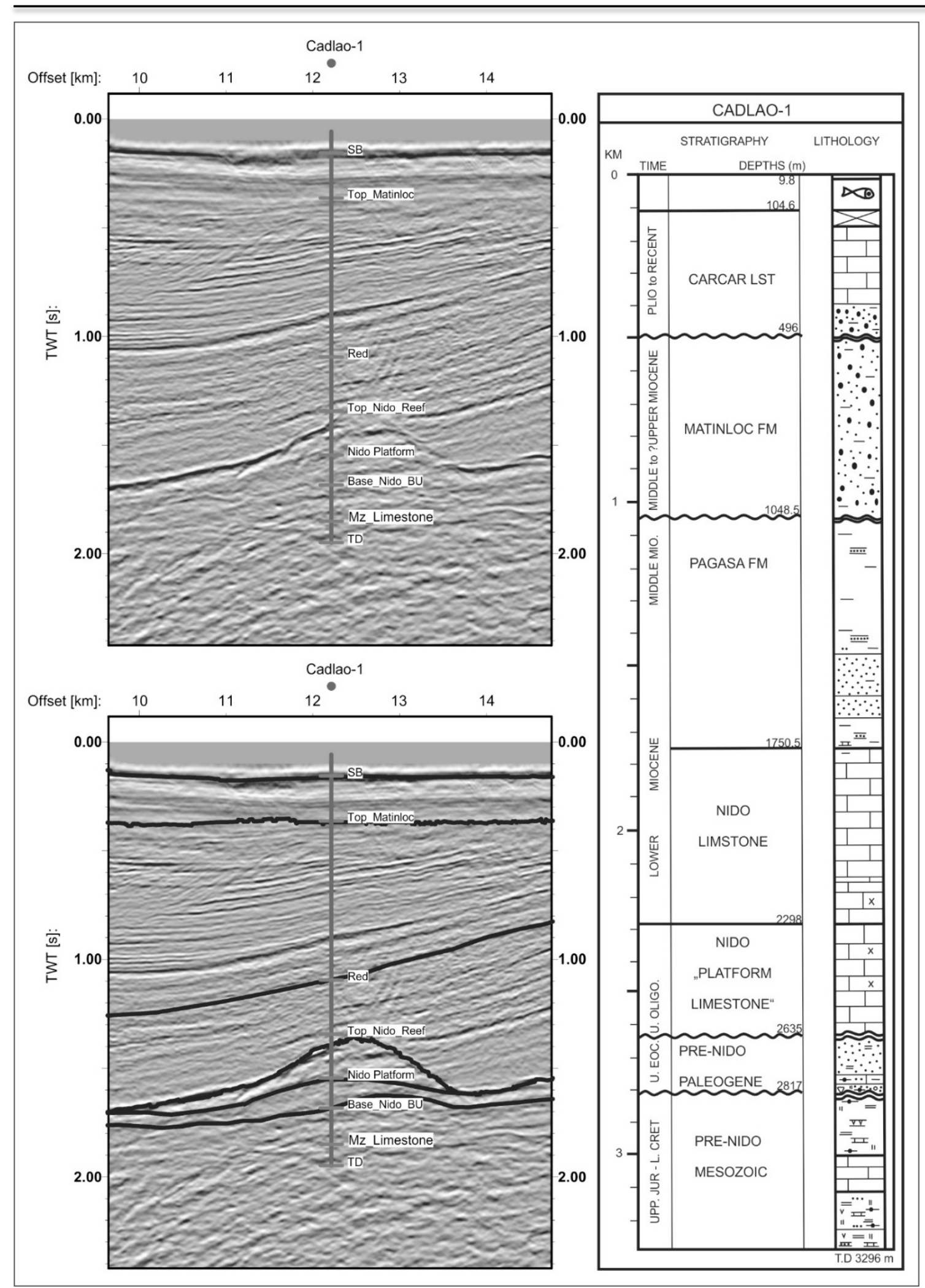

Figure 29: Seismic image of the carbonate platform and a Miocene reef on top at the location of the Cadlao-1 well. The vertical scale is given in two-way-time. The most distinct reflection is the positive reflector on top of the carbonates. The "Red" unconformity is represented by a weak reflector, indicating that at this point it rather represents the top of a clastic succession than an erosional unconformity. The interpreted horizons are matched to the drilled stratigraphy of the well Cadlao-1 given at the right side. 


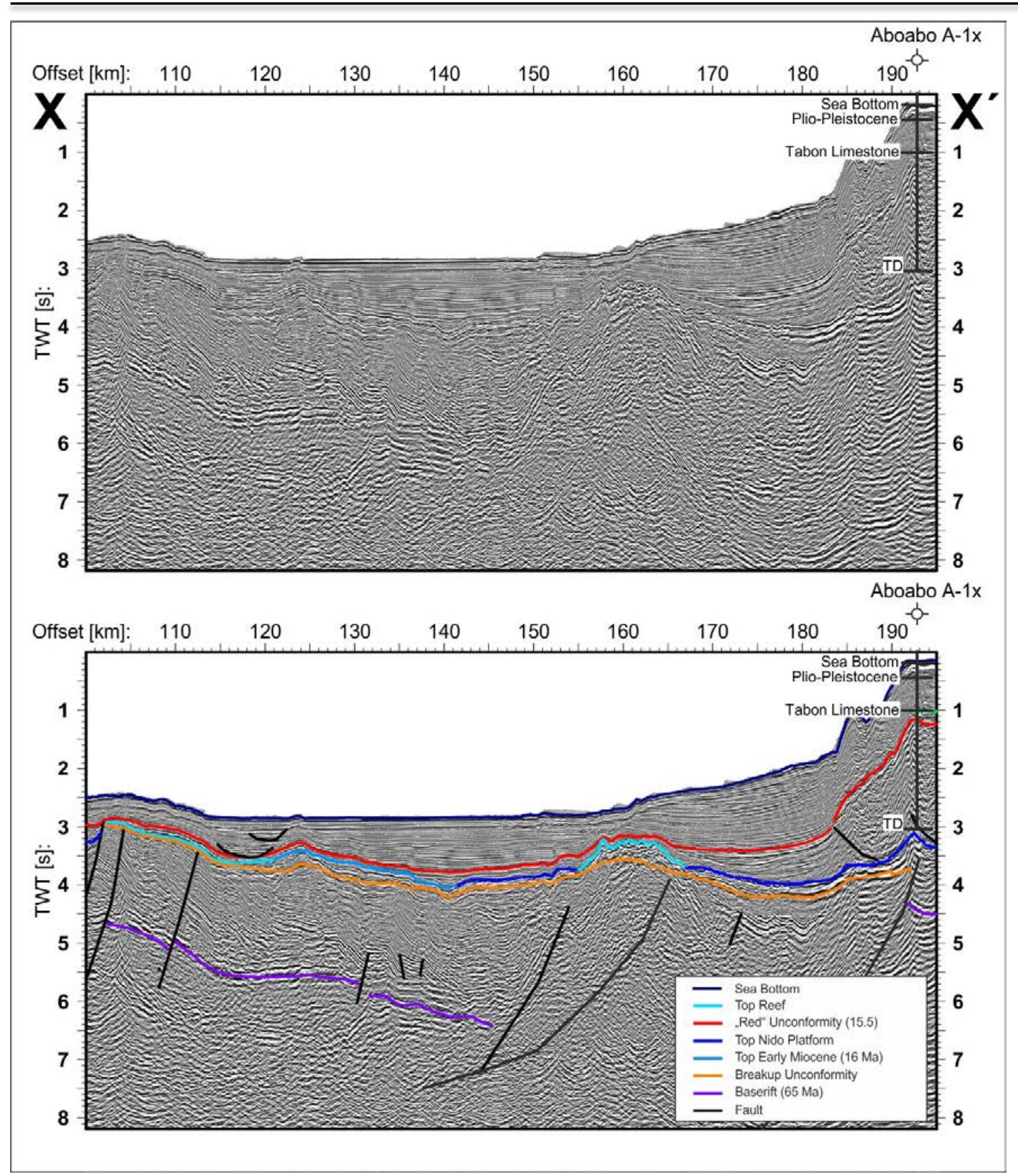

Figure 30: Image of a 2D multichannel seismic line in NW-SE-direction across the Borneo-Palawan trough at the well Aboabo A-1X, offshore southern Palawan. The vertical scale is given in two-way-time, the horizontal scale is in kilometer. The base of the carbonate platform is sealing most of the extensional tectonics before it was overthrusted by the PalawanBorneo wedge (right). The "Red" unconformity is located well above the carbonate platform. So it is a post-rift-feature in the trough. Parts of the strata underneath this unconformity are incorporated in the wedge. 


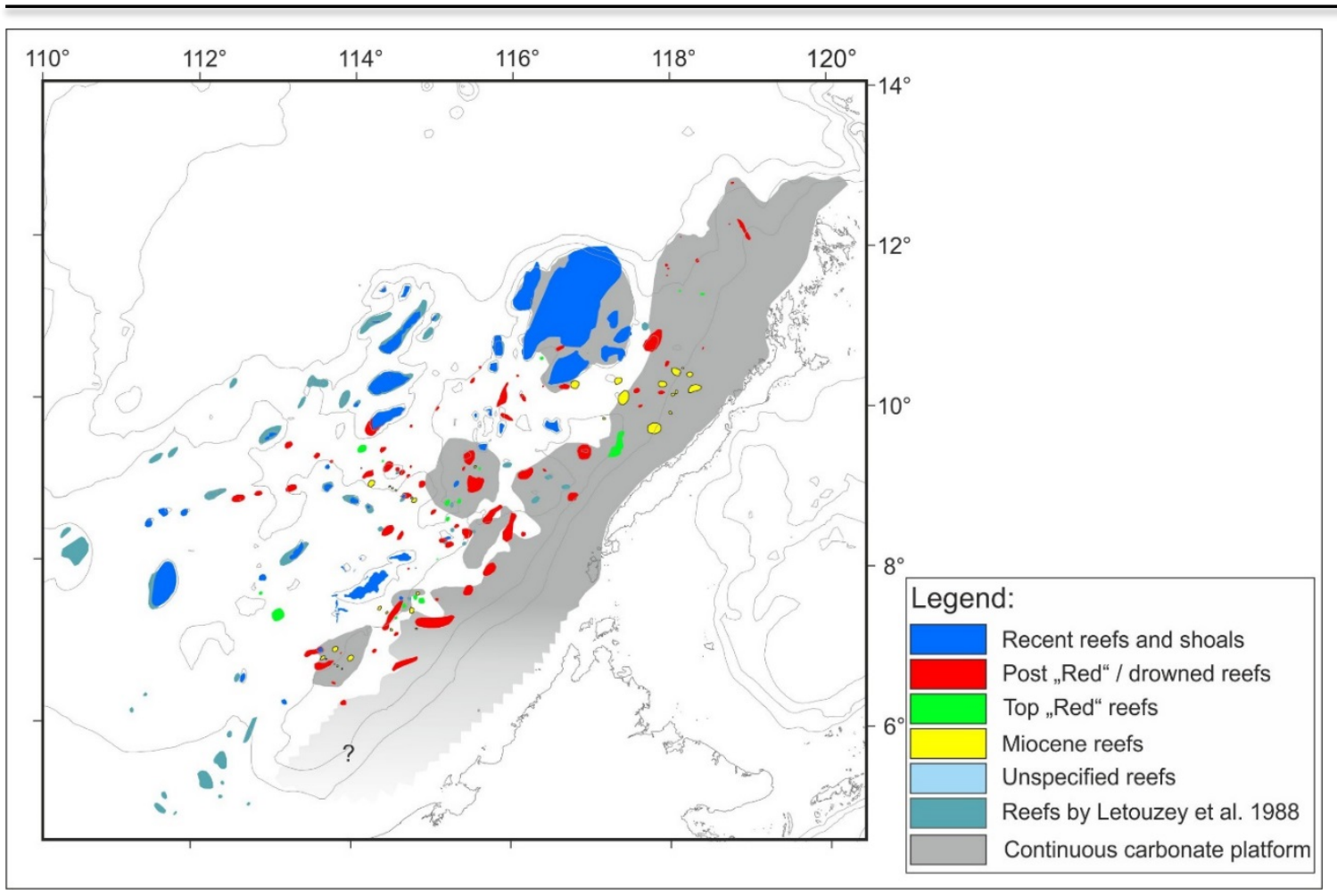

Figure 31: The distribution of the Oligocene-Miocene carbonate platform and the position of reefs in the Dangerous Grounds. Areas where the existence of the carbonate platform is less clear are shaded in lighter gray. Reefs were categorized according to the end of their development and marked with different colors. Reefs taken from literature (Letouzey et al., 1988) or with unknown age for the end of development are also given in this map. An elongated cluster of "post red drowned reefs" is located at the western edge of the carbonate platform, the development of these reefs probably is related to the development of the Palawan-Borneo trough.

We classify the Miocene reefs into 4 groups, according to the timing and reasons for the end of their development. The reference level for this is the previously described unconformity "Red" (15.2 Ma), the letters refer to Figure 32:

- Early Miocene reefs (A) are completely covered by the clastics that underlie the "Red" unconformity (e.g. the Pagasa Formation). These reefs ended their development clearly before the formation of unconformity "Red". The coverage by the Pagasa formation indicates a drowning of these reefs due to strong subsidence in the Borneo-Palawan trough that may be caused by the loading of the Borneo-Palawan accretionary wedge. Alternatively or additional a sea-level rise at the Oligocene/Miocene boundary as proposed by Williams (1997) may have caused the drowning of these reefs. Early Miocene reefs are predominately found between the Reed Bank and Palawan Island. Some of them are also present on the western edge of the Palawan-Borneo trough. In the Palawan-Borneo trough an increased sediment input from the east may have also contributed to end the reef development.

- Top "Red" reefs (D) continued to develop until the formation of the "Red" unconformity. These are cut at the top by the "Red" unconformity.

- Post “Red”/Drowned reefs (B, C) continued to grow after the "Red” unconformity. The interpreted horizon associated with the unconformity onlaps on the reefs. In several places these reefs reach up to the present sea bottom but are now in water depths greater than $1 \mathrm{~s}$ TWT (c. $750 \mathrm{~m}$ ). 
- Recent ("keep up”) reefs and shoals occur in water depths significantly less than $750 \mathrm{~m}$ and, in most cases, reach the sea level or build up small islands like the Spratley Islands or Reed Bank. Reefs without clastic cover in water depths up to $750 \mathrm{~m}$ are also put in this group even though there is most probably no active reef development in such high water depths.

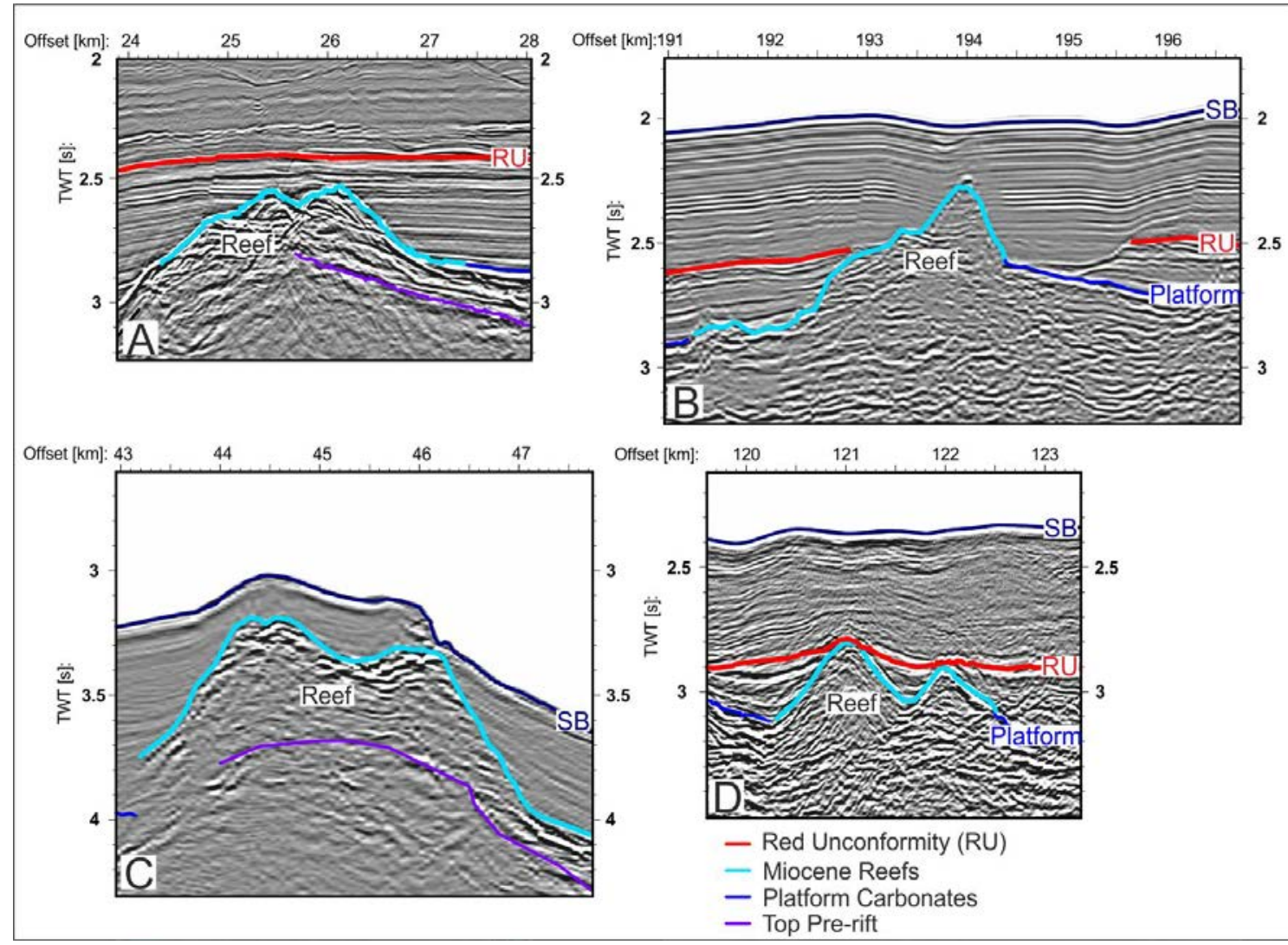

Figure 32: Seismic images of reefs ending their development at different times. The reference horizon for timing the development is the "Red" unconformity (RU). The reefs could be clearly identified by their specific shape in the seismic image. A: Early Miocene reefs are covered by Early Miocene strata and therefore ended their development prior to the formation of the RU; B,C: Post-"Red"/drowned reefs continued to develop during the Early Miocene and are not affected by the RU. They are draped by Middle Miocene or younger sediments. This sedimentary cover occasionally is very thin ( 0.2 s TWT) as shown in C; D: Top "Red" reefs are cut at their top by the RU indicating uplift above sea level in the Early Miocene. 


\section{Tectonic evolution of the Reed Bank Block}

The continental Reed Bank block, directly north of the Dangerous Grounds is outstanding in the evolution of the area. Rifting substantially affected the Reed Bank block in the Early Paleocene, resulting in a significant rift onset unconformity. Most Late Cretaceous strata were eroded. Wells on the Reed Bank drilled pre-rift upper Lower Cretaceous (Alb.-Abt.) marly siltstones to sandstones. These rocks are unconformably overlain by Paleocene formations. In the Kalamansi-1 and Sampaguita-1 well a succession of synrift sediments was drilled. These sediments can be correlated with the three rifting episodes in the Paleocene, Early to Middle Eocene and Late Eocene to Early Oligocene as described for the northern margin of the South China Sea (Zhou et al., 1995). The youngest sediments prior to the carbonate deposition are sandstones and clays of a sublittoral to littoral facies.

The development of platform carbonates initiated on Reed Bank in the Early Oligocene (w30 Ma) and continued without interruption until the Pleistocene (Figure 34). To check for the continuity of the carbonate section we calculated the average growth rates of the carbonates on Reed Bank. Major changes in the growth rate or unusually high or low rates could give indications on tectonic events as e.g. uplift. The calculated average growth rate between $30 \mathrm{Ma}$ and $14.5 \mathrm{Ma}$ is $48 \mathrm{~m} / \mathrm{My}$, between 14.5 Ma and 2.5 Ma $98 \mathrm{~m} / \mathrm{My}$ and $137 \mathrm{~m} / \mathrm{My}$ for the time since 2.0 Ma. We conclude that the initiation of carbonate sedimentation started prior to the breakup of the SW-Subbasin of the South China Sea ( 25 Ma (Barckhausen and Roeser, 2004)). Since the Early Oligocene the Reed Bank Block was continuously submerged below sea level. Unlike in many areas around the South China Sea we see no evidence for a "Breakup Unconformity" in the seismic sections and the drill data of the wells at Reed Bank. 


\section{Discussion}

\section{The paleo-landscape during the Early Miocene}

From the distribution of the reefs and the position of the major erosional unconformities we deduce a generalized paleogeographic map for the central part of the Dangerous Grounds during Early Miocene times (Figure 33). Reefs whose tops are cut by the "Red" unconformity are considered to represent the remains of Early Miocene islands. Widespread erosional unconformities also indicate exposed landmasses. The sediments provided by these landmasses likely were deposited in the surrounding marine areas and terminate the growth of the preexisting reefs there. We therefore suggest the "Early Miocene reefs" were submerged but quite close to an island or landmass in the Early Miocene. More distal from these islands the sediment influx was not sufficient to completely cover the reefs. Therefore these continued to develop during the Upper Miocene until they finally drowned (post "Red”/Drowned reefs). These reefs are sometimes still visible in the bathymetry, but the water depth is nowadays too large for further reef development.

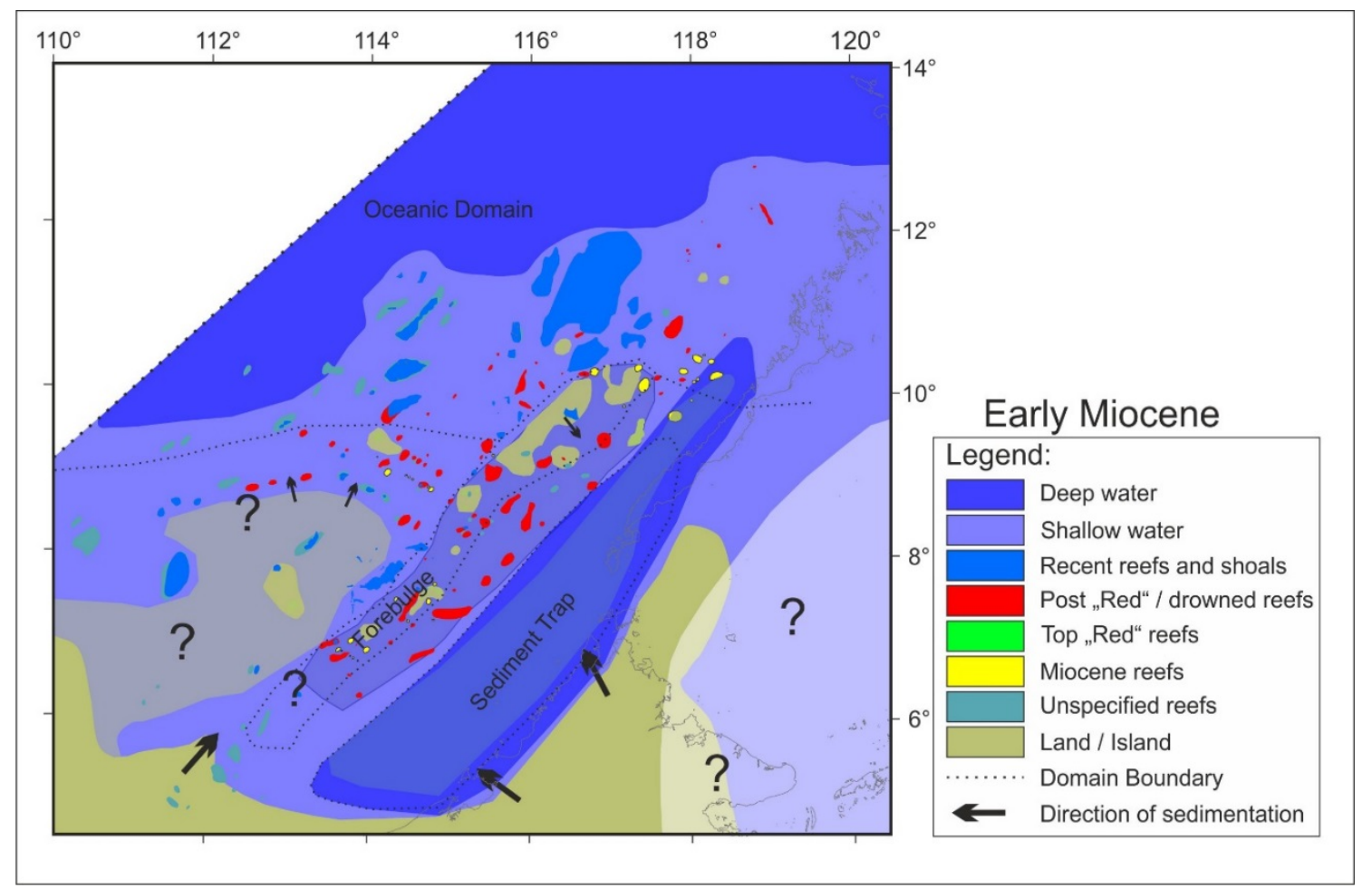

Figure 33: Paleo-landscape of the Dangerous Grounds in the Early Miocene as inferred from the position of reefs and unconformities as shown in fFigure 31. For orientation the present coastline is shown as thin, continuous line. The area is divided into three parts. The oceanic domain is almost completely submerged and covered by deep water. The PalawanBorneo trough acts as trap for sediments provided by a landmass in the southeast, the main directions of sedimentation are indicated by arrows. Due to this sediment trap only a minor amount of clastic sediments was deposited in the central Dangerous Grounds. The forebulge provided shallow water conditions favorable for reef development. Partly this forebulge was above sea level and most of the islands in Early Miocene times are located on it. There was probably another landmass southwest of the forebulge, due to our limitation of seismic lines in this area its outline is speculative. 


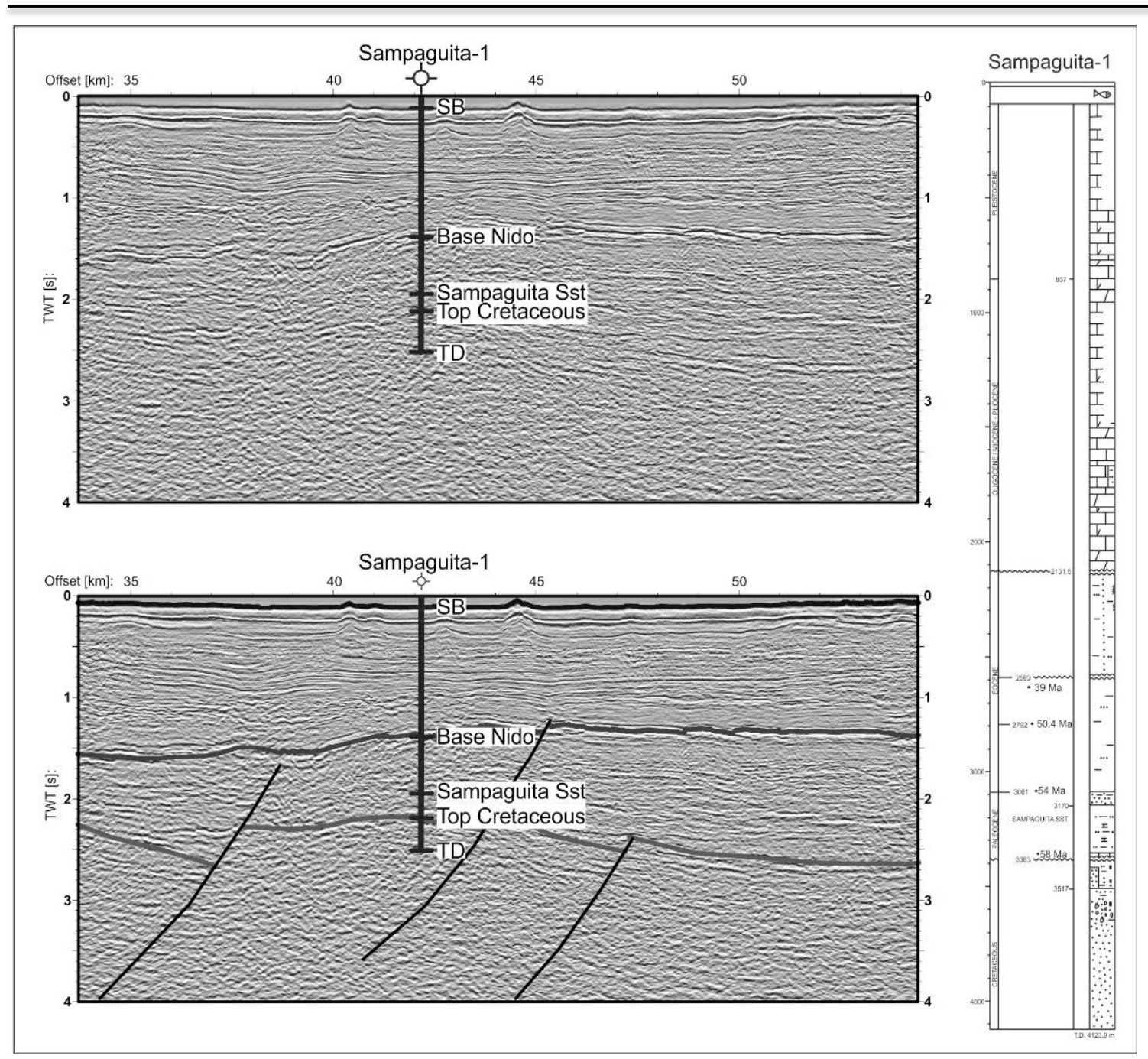

Figure 34: 2D seismic line across the Reed Bank block at well Sampaguita-1. On the Reed Bank block the carbonates also seal the extensional tectonics. In contrast to the Dangerous Grounds the carbonate deposition on the Reed Bank initiated in the Early Oligocene ( 30 Ma) and continued until present as it is also indicated in the lithology of the well at the right side of the figure.

The most important sediment source was in the southeast, where emerging portions of northern Borneo provided massive influx of sandstones and conglomerates (Cullen, 2010) but these sediments were mainly trapped in the Borneo-Palawan trough. An additional source for sediments was the emerged Luconia platform (Mansor et al., 1999). In the central part of the Dangerous Grounds area the sediments were partly ponded or distributed along the submerged half grabens (Hutchison, 2004). Offshore northwest Palawan and between Palawan and Reed Bank the reefs are covered by clastic sediments, indicating an uplift of northern Palawan at $12 \mathrm{Ma}$ (Steuer et al., 2013). In Figure 31 an elongated cluster of c. 35 reefs is distinct at the western edge of the Borneo-Palawan trough. This area is approximately $100 \mathrm{~km}$ wide and extends from southeast of Reed Bank over at least $600 \mathrm{~km}$ toward the southwest. The shape in our view implies a relationship with the collision of the Dangerous Grounds with Borneo and Palawan. We suggest that the formation of a flexural forebulge in front of the Borneo-Palawan trough provided the appropriate water depth for reef formation. In the Early Miocene south of Reed Bank there were two larger islands and about six 
smaller islands in this area. Rapid drowning of the entire Dangerous Grounds after Middle Miocene times ended the reef evolution.

Isolated reefs occur in the central parts of the Dangerous Grounds. The scarcity of available seismic lines in the southwestern part of the Dangerous Grounds hinders an interpretation of the stratigraphic position of these reefs. Hutchison and Vijayan (2010) describe them as post Middle Miocene, so we assigned them to the Post "Red"/Drowned reefs. By integrating these data we resolve a distinct zonation of reef development across the Dangerous Grounds (Figure 33):

- In the northwestern part, including the Reed Bank and the Spratly Islands we propose the oceanic South China Sea as the main controlling factor. This area was almost completely submerged since the breakup of the oceanic SW-Subbasin of the South China Sea. Reed Bank and the apex of tilted fault blocks remained in shallow waters since Oligocene times, allowing carbonate development until Present. Single reefs reach up to the water surface (Spratly Islands).

- The Borneo - Palawan trough formed as a result of the collision between Borneo and Palawan Island with the Dangerous Grounds. Subsequently the major portion of sediments, delivered from the east and southeast since Early Miocene times, were trapped in this depression or already on the shallow shelf of the developing wedge (Hall and Nichols, 2002; Morley and Back, 2008). A vast part of the sediments were incorporated in the Palawan-Borneo wedge by a combination of further crustal shortening and gravity tectonics (Franke et al., 2008; Hesse et al., 2009, 2010b; King et al., 2010).

- The forebulge of the collision area is characterized by many reefs of varying size. While there are numerous small emerged reefs we also found larger areas where the "Red" unconformity forms amajor angular unconformity cutting down in older formations. By mapping the extent of this angular unconformity we found evidence for two Early Miocene islands with a non-reefal origin, which are located to the south of Reed Bank (Figure 33). They are also seen as sediment source in the central Dangerous Grounds but here the majority of the sediment was trapped in the underfilled half-grabens of the Dangerous Grounds.

- In the central part of the Dangerous Grounds the image is more ambiguous. There are indications for some Early Miocene islands but vast parts of the central DG remained submerged during the "Red”-event allowing further reefal development. The scarcity of available seismic lines does not allow for a more precise description. 


\section{Sea level variations}

The demise of carbonate platforms has variously been related to factors such as tectonics, influx of clastic material, and environmental stress, sometimes in combination with eustatic fluctuations. According to Ma et al. (2011) and Haq et al. (1987) the changes in sea level are minimal in the Middle Miocene. The variations lie well inside the growth potential of carbonates (Schlager, 1981). We can therefore exclude global changes in sea level as course for the termination of carbonates in the Dangerous Grounds.

\section{Post Middle Miocene development}

After the widespread erosional event in the Early to Middle Miocene, the Dangerous Grounds underwent subsidence. In the east the compression and thrusting continued until the Late Miocene with the formation of the Palawan Borneo wedge (Steuer et al., 2013) and the uplift of Palawan Island. Sediments provided from Palawan and Borneo are mainly trapped in the Palawan Borneo trough and in the half grabens (Hutchison and Vijayan, 2010) leading to the underfilling of the rift structure in the area of the Spratly Islands, which can be still recognized in the bathymetry. In the central part of the Dangerous Grounds the preexisting seafloor topography was draped by sediments. These sediments are approx. $0.5 \mathrm{~s}$ TWT thick and show parallel bedding. The general scarcity of clastic sediment input also aided the development of reefs in the whole Dangerous Grounds. A catastrophic fall in eustatic sea level after 10.5 Ma proposed by Haq et al. (1987), resulted in the formation of a major unconformity all across the South China Sea shelf and resulted in a peak in sedimentation at the continental slopes as it is exemplarily described for the conjugate NW-margin at ODP Site 1148 (Clift et al., 2002a).

\section{Development of the forebulge}

Suitable depositional conditions for carbonates were provided during Oligocene-Early Miocene all along the Borneo-Palawan Trough. This continuous deposition of the "Nido" platform carbonates implies a structural relationship with collision-related structures onshore Borneo and Palawan. The thrusting of the Crocker/Pulute wedges onto the downgoing Dangerous Grounds plate certainly caused a down bending of the rifted continental crust of the Dangerous Grounds. This bending resulted in the formation of a foredeep that is still preserved as the Borneo-Palawan Trough. Further toward the northwest the formation of a forebulge would be the natural consequence. We suggest that on the elevated positions of this forebulge the initial deposition of carbonates took place in shallow water facies. With the subsequent propagation of the Borneo-Palawan thrusted wedge toward the northwest (Hesse et al., 2010c; Morley et al., 2003), the position of the foredeep and the forebulge also moved toward the northwest. This likely resulted in the drowning of the carbonate platform on its southeastern end and the propagation of the platform toward the northwest. This would result in a strong time-transgressive development of the Nido carbonates. The current 
position of the elevated forebulge is recognizable in the seismic, e.g. on the left side of the lower section of Figure 27. Such a concept is also supported by the distribution of the younger reefs (Figure 31 and Figure 33). Reefs that were drowned during the Early Miocene, are located predominantly in the eastern part of the Dangerous Grounds. These reefs developed mainly on top of the Nido carbonate platform. The deepwater facies overlying the reefs indicates rapid drowning. In the area of the central Dangerous Grounds, further toward the west, only the tips of tilted fault blocks provided the shallow water conditions for the development of small carbonate platforms or isolated reefs, while the major part of the southern Dangerous Grounds likely was above sea level. A general northward tilt of the Dangerous Grounds is implied by our data. The submergence of the platform in the east was fast, as indicated by the deepwater clayish Pagasa Formation burying the shallow water carbonates.

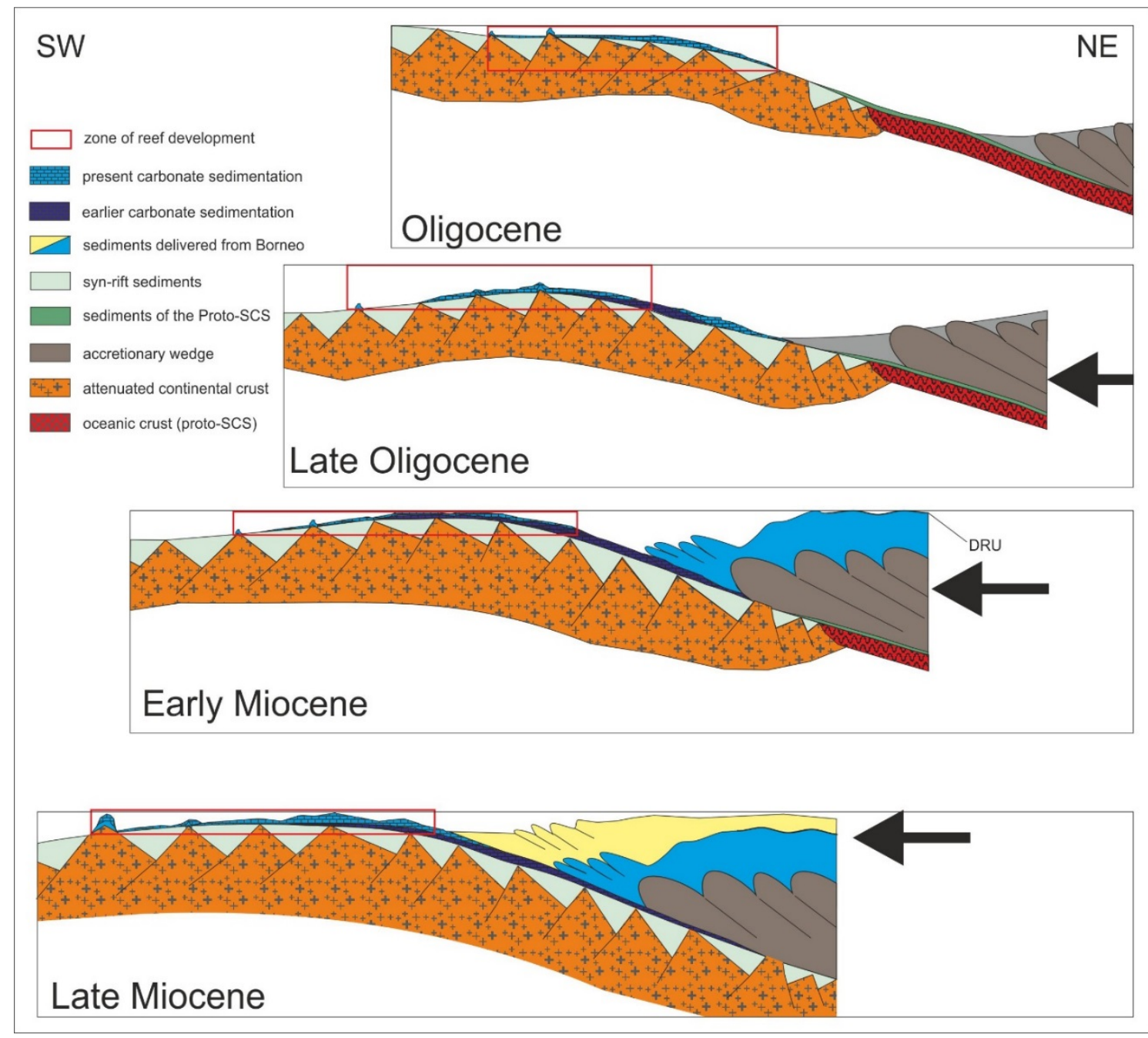

Figure 35: Schematic development of the carbonate platform on top of a forebulge. This section is running in NW-SE direction in the southern part of the Dangerous Grounds. In the Oligocene the carbonate development initiated on the highest crests of tilted fault blocks. With the uplift of the forebulge, caused by the arrival of the wedge (right) the shallow water conditions with active carbonate development migrated toward the northwest while in the southeast the carbonates drowned. A red rectangle is indicating the NW migrating zone of active carbonate deposition. In the Early Miocene parts of the carbonates were exposed, on the wedge the Deep Regional Unconformity (DRU) forms. In the Late Miocene the convergence had stopped. The frontal part of the wedge is deformed by gravitational tectonics and the Dangerous Grounds undergo subsidence. In many places reefs were able to keep up and to further develop until present. 
The development of carbonates on the western end and the rapid drowning of the platform at its eastern end continued until the early Middle Miocene offshore Borneo. Tilting and uplift of the NW Borneo margin resulted in a major change in the sedimentation pattern and the formation of the ‘Deep Regional Unconformity’ (late Early Miocene (Cullen et al., 2010; Levell, 1987)), which marks a change from generally deep marine clastic sedimentation from younger clastic shelf/slope deposits. In the area of south Palawan thrust tectonics continued much longer, until the Late Miocene (Steuer et al., 2013). After the Middle Miocene the Dangerous Grounds generally underwent subsidence. Only locally reefs could keep up the pace of the subsidence in the Dangerous Grounds before they also were drowned. On elevated structures like the crests of tilted fault blocks the reef development continued until present.

The "Red" unconformity and the coeval "Top Pagasa Formation” horizon in the Palawan Borneo trough seal the extensional tectonics in the southern Dangerous Grounds. After the "Red" unconformity only quiet subsidence took place in the southern Dangerous Grounds leading to parallel bedded sediment deposition, draping the underlying structures.

The top Early Miocene horizon represents the top of a clastic sedimentary layer in the DG. It was deposited at the end of the rifting period and is only displaced sporadically by large normal faults limiting large half-grabens.

\section{Conclusions}

By tracing a prominent seismic reflection, we derive the regional extent of an Oligocene-Early Miocene carbonate platform in the Borneo-Palawan trough and in the Dangerous Grounds. This carbonate platform is well known from NW Palawan where it was penetrated by several wells. From the appearance in the seismic data the platform carbonates are continuous to NW Borneo and underlie the entire Borneo-Palawan trough. However, further west only patchy parts are interpreted as platform carbonate deposits.

Here, this prominent seismic reflector marks the top of a clastic succession. On the top of tilted fault blocks and in the southwestern part of the Dangerous Grounds this Early Miocene reflector represents an erosional phase.

The "Red” unconformity is not continuous across the Dangerous Grounds. We deduced a paleomap for the Dangerous Grounds during this large erosional event. The accumulation of islands along the western edge of the Palawan-Borneo trough leads to the conclusion that this area was stronger uplifted/exposed during the event. This may be related to the additional uplift caused by the development of a forebulge of the trough.

The northern Dangerous Grounds were not or only slightly affected by the uplift. Continuous carbonate development on the Reed Bank and also in the area of the Spratly islands indicates shallow water conditions in that area since the Oligocene. 
In the central part of the Dangerous Grounds the erosional event only affected the highest tips of tilted fault blocks. In many places the reef development was also continuing through this event. Toward the south the influence of the erosional event grew. The area of the Luconia platform and the adjacent southern Dangerous Grounds were elevated and eroded. The Palawan-Borneo Trough is considered as a foreland basin created by the down bending of the crust by the overthrusting of the Crocker/Pulute wedge.

The platform carbonates were found continuously deposited all along the Palawan-Borneo trough and NW Palawan. We propose a concept in which the development of these carbonates was aided by the formation of the forebulge of this foreland basin. As the overthrusting moved northwestward the eastern parts of the platform were drowned and subsequently overthrusted by the wedge while the deposition of the carbonates followed the shallow water conditions on top of the forebulge toward the northwest. This would result in a strong time transgressive development of the Nido platform as it is drawn schematically in Figure 35. The sudden change between very shallow water carbonates and the overlying deep marine clays in the trough indicates a very rapid subsidence of the trough. Reefs are widespread in the Dangerous Grounds. They started to develop in the Early Miocene more or less coeval to the drowning of the carbonate platform. Some isolated reefs were able to keep pace with the subsidence until the late Miocene. These buildups are not or only slightly covered by younger clastic sediments.

The Reed Bank block showed a different tectonic history. Like the north Palawan block it was rifted during the Paleocene and Eocene. But while the north Palawan block drifted away from mainland China with the opening of the South China Sea at $31 \mathrm{Ma}$, the Reed Bank block remained attached to the Macklesfield Bank. These two blocks were separated during the opening of the SW Subbasin of the South China Sea at about 25 Ma. The Reed Bank Block was submerged below sea level probably since the Eocene. The development of carbonates started at 30 Ma way before the breakup of the SW-Subbasin and the separation of Reed Bank and Macklesfield Bank. The carbonate sedimentation was continuous until the end of Pliocene.

\section{Acknowledgments}

We gratefully acknowledge Total Exploration \& Production for supporting this study, for supplying data and allowing publication of these results.

We benefited greatly from constructive reviews from Andrew Cullen, Chris Morley and an anonymous reviewer which considerably helped to improve the manuscript.

Funding of this study by Total E\&P is kindly acknowledged. 


\section{Chapter 4: Time constraints on the evolution of Southern Palawan Island, Philippines from onshore and offshore correlation of Miocene Limestones (Journal of Asian Earth Sciences, 2013)}

Stephan Steuera, Dieter Frankea, Florian Meresseb, Dimitri Savvab, Manuel Pubellierb, Jean-Luc Auxietrec, Mario Aureliod

aBundesanstalt für Geowissenschaften und Rohstoffe BGR, Stilleweg 2, 30655 Hannover, Germany „Ècole Normale Supérieure ENS, 24 Rue Lhomond, 75231 Paris cedex 5, France

‘Total E\&P Exploration, 2 Place Jean Millier, 92078 Paris La Défense cedex, France

dNational Institute of Geological Sciences, University of the Philippines, Diliman, 11011 Quezon City, Philippines

\section{Abstract}

The link between the deformation of southern and central Palawan Island, Philippines and the deformation of the adjacent offshore wedge is investigated. The wedge is a continuation of the Palawan fold and thrust belt and bounds the Borneo-Palawan Trough to the Dangerous Grounds and to Palawan Island. Key parameters for the understanding of the formation and development of this wedge are two limestone formations:

The Oligocene to Middle Miocene Nido limestone and the Upper Miocene to Lower Pliocene Tabon limestone. The initiation of the thrust belt formation is constrained by the Nido limestone, which was deposited from shortly before the breakup of the eastern South China Sea ( $35 \mathrm{Ma}$ ) until the Early Miocene. Age data available from wells offshore central Palawan gives an age of Early Miocene close to the base of the Nido limestone. While cropping out onshore north Palawan, these limestones were overthrusted by the wedge in southern and central Palawan. Seismic images show gently east dipping carbonates below the wedge. The seismic data show that these limestones are only mildly affected by the wedge formation.

The end of the wedge development can be constrained by the Tabon limestone. With an age of $\sim 9$ to $\sim 4 \mathrm{Ma}$, this limestone sequence overlies unconformably the offshore wedge. A detailed biostratigraphic correlation of the Tabon limestone along the southwest Palawan shelf, using well data, combined with multichannel seismic data and investigations onshore southern and central Palawan, shows a time and space-transgressive development of these limestones. They are progressively younging towards the west. We propose that the formation of the Tabon limestone is directly linked with the development of the wedge that tectonically controls the formation of this carbonate platform. This constrains the time for the final phase of the formation of the Palawan thrust belt. After the final compressional phase and wedge formation in the lower Early Pliocene the wedge underwent a phase of subsidence. 
Based upon the detailed correlation of these limestones we propose that the wedge did not form in the southern Palawan area prior to $18 \mathrm{Ma}$. Using the sealing Tabon limestone as time constraint we suggest that the development of the wedge in the south Palawan area started in the lower Middle Miocene ( $15 \mathrm{Ma}$ ) and continued developing towards the west until the upper Late Miocene to Early Pliocene ( 5 Ma).

After the wedge propagation stopped, the wedge front collapsed in several places due to gravitational sliding.

Southern and central Palawan were uplifted above sea level during a second phase of compression in the Late Pliocene. Onshore outcrops give indications to a working spleothem since 1.2 Ma.

\section{Introduction}

The island of Palawan, is located between the South China Sea and the Sulu Sea in the southwestern part of the Philippines. It stretches about $600 \mathrm{~km}$ in NE-SW direction and consist of at least two major tectonostratigraphic blocks (McCabe and Almasco, 1983; Schlüter et al., 1996). Northern Palawan is dominated by rocks of a continental margin affinity thought to have rifted from mainland China. It is also referred as North Palawan continental block (Holloway, 1982). It is commonly assumed that this block drifted from mainland China to the present position during the Oligocene to Early Miocene seafloor spreading stage of the South China Sea. In contrast, central and south Palawan are considered to be emerged imbricated thrust belts (Hinz and Schlüter, 1985), which were overthrusted by an ophiolitic formation. The N-S trending Ulugan Fault Zone (Figure 36) divides Palawan Island and its western shelf. The offshore position of this structure is speculative; however, its proposed position marks the eastern boundary of the thrusted wedge (Pulute Formation), which is confined to only the central and southern part of the shelf (Figure 36 and Figure 43).

For simplicity and orientation we subdivide the island of Palawan into three parts as indicated in Figure 36. When we refer in the following to northern Palawan this comprises the island to the north and east of the Ulugan Bay and the Ulugan Fault Zone $\left(10^{\circ} \mathrm{N}\right.$

$\left.118^{\circ} 50^{\prime} \mathrm{E}\right)$. Central Palawan, to the south and west of the Ulugan Bay ranges as far south as to the City of Quezon $\left(09^{\circ} 14^{\prime} \mathrm{N}, 118^{\circ} \mathrm{E}\right)$. Finally, southern Palawan is south of Quezon City and includes Balabac Island (Figure 36). 


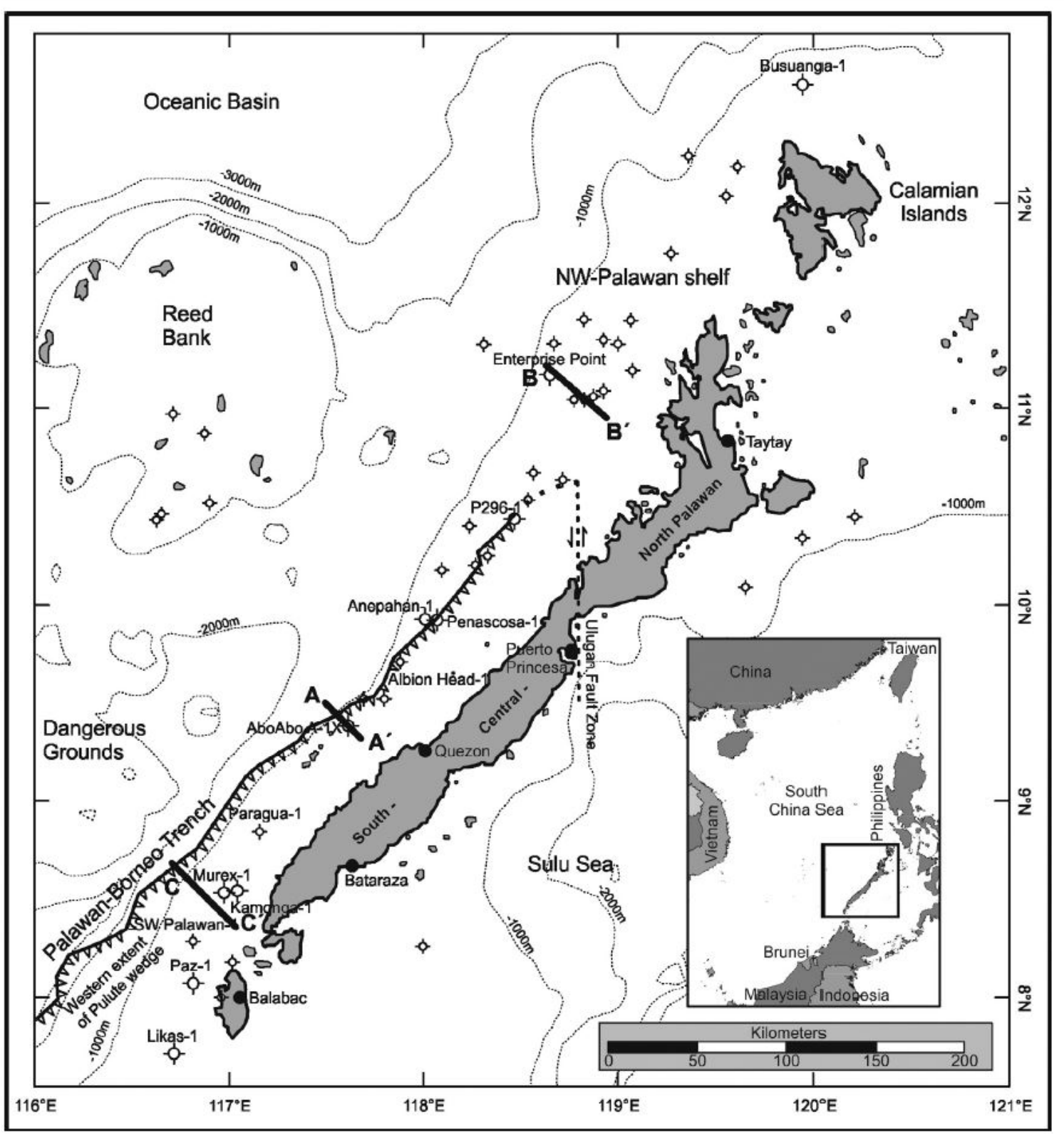

Figure 36: Regional map showing the locality of Palawan Island and main tectonic features, as well as the location of wells offshore Palawan. Wells which are referred to in the text are enlarged and the names are shown in the map. Solid black lines indicate the locations of the three seismic lines shown in figures XXX. The extend of the offshore accretionary wedge is indicated. The bathymetric data is taken from the General Bathymetric Chart of the Oceans (GEBCO)

The general change in the onshore geology (Figure 38) between North Palawan on the one hand and central and south Palawan on the other hand coincides with remarkable variations in bathymetry. The most striking bathymetric feature offshore Palawan is the

Borneo-Palawan Trough. As shown by Hinz and Schlüter (1985) and pointed out by Hutchison (2010) there is no northern extension of the Borneo-Palawan Trough between the Reed Bank and the NW Palawan microcontinental block. The trough thus may be a collisional foredeep. Central and south Palawan are considered to be emergent imbricated thrust belts, that developed subsequent to the early Middle Miocene collision between the Cagayan volcanic arc and the NW Palawan microcontinental block (Holloway, 1982; Letouzey et al., 1988; Taylor and Hayes, 1983). The 
thrust belts might have originated from the Northwest Sulu Sea Basin thrusted onto the highly stretched Dangerous Grounds continental block (Hinz and Schlüter, 1985; Schlüter et al., 1996). With the ongoing spreading of the South China Sea, an older region of oceanic crust, the ProtoSouth China Sea (Hall et al., 2008; Hinz et al., 1989; Morley, 2002) was consumed beneath NW Borneo. In Early Miocene times, the continental crust of the Dangerous Grounds entered the subduction zone, before its buoyancy blocked the system in the latest Early Miocene (Hinz et al., 1989; Hutchison, 1996; Milsom et al., 1997).

The thrust belts might have originated from the Northwest Sulu Sea Basin thrusted onto the highly stretched Dangerous Grounds continental terrane (Hinz and Schlüter, 1985; Schlüter et al., 1996). Offshore NW Borneo, two key mechanisms have been discussed in the past as main controlling factors for deepwater compressional deformation (Franke et al., 2008; Hesse et al., 2010c; Ingram et al., 2004); (1) basement-driven crustal shortening and (2) gravity-related tectonics.

The transition from predominantly basement-driven crustal shortening around central and southern Palawan to the mainly gravity related delta tectonics offshore NW Borneo may be indicated by the high-velocity body (Franke et al., 2008) marking considerable variation in the structural style within the deepwater NW Borneo fold and thrust belt (Hesse et al., 2010a).

In any case, the formation of central and south Palawan is related to the closure of a Proto-South China Sea. However, it is still unclear if the accretionary wedge of central and south Palawan rests on pieces of continental crust (the Dangerous Grounds block,

or the NW Sulu Sea basin) or on remnants of the Proto-South China Sea. Moreover, the timing of the assumed collision or collisions is widely speculative.

Underpinned by detailed biostratigraphic correlation and seismic interpretation, we present a method to constrain the timing of the collision by dating two carbonate sequences being located on top and below the accretionary wedge. Both carbonate sequences are only slightly affected by the wedge formation and provide therefore time constraints for the wedge development.

\section{Geological Setting}

Palawan Island and its shelf consist of two different blocks separated by the Ulugan Fault Zone. A generalized offshore stratigraphy with the main interpreted unconformities is shown in Figure 37. For location of the onshore geologic units see geologic map (Figure 38).

\section{Northern Palawan}

The northern portion of Palawan is dominated by rocks of continental affinity which were likely rifted from mainland China. It consists of Jurassic olistostromes containing olistoliths of Permian limestone, Permian and Triassic chert, sandstone and basaltic rocks in a predominantly mudstone matrix (Aurelio, 2010; Suzuki et al., 2000). 


\section{Barton group}

The Barton group, covering the central and southern part of northern Palawan, is made of slightly metamorphic Cretaceous rocks (Aurelio, 2010). It is subdivided into the Caramay Schist, Cretaceous muscovite schists in the east, the Conception Phyllite, Cretaceous phyllites adjacent to the Caramay Schist and the Boayan Formation, Late Cretaceous sandstones and mudstones (Aurelio, 2010). These successions were deposited in deep submarine fans and basinal plains (Suzuki et al., 2000) and deformed during the collision of the North Palawan block with the Philippine Mobile Belt. The composition of these sandstones support the proposal that these clasts originated from a continental source region (Suzuki et al., 2000). Suzuki et al. (2000) proposed southern China (Kwangtung and Fukien regions) as the source area for these sandstones. 


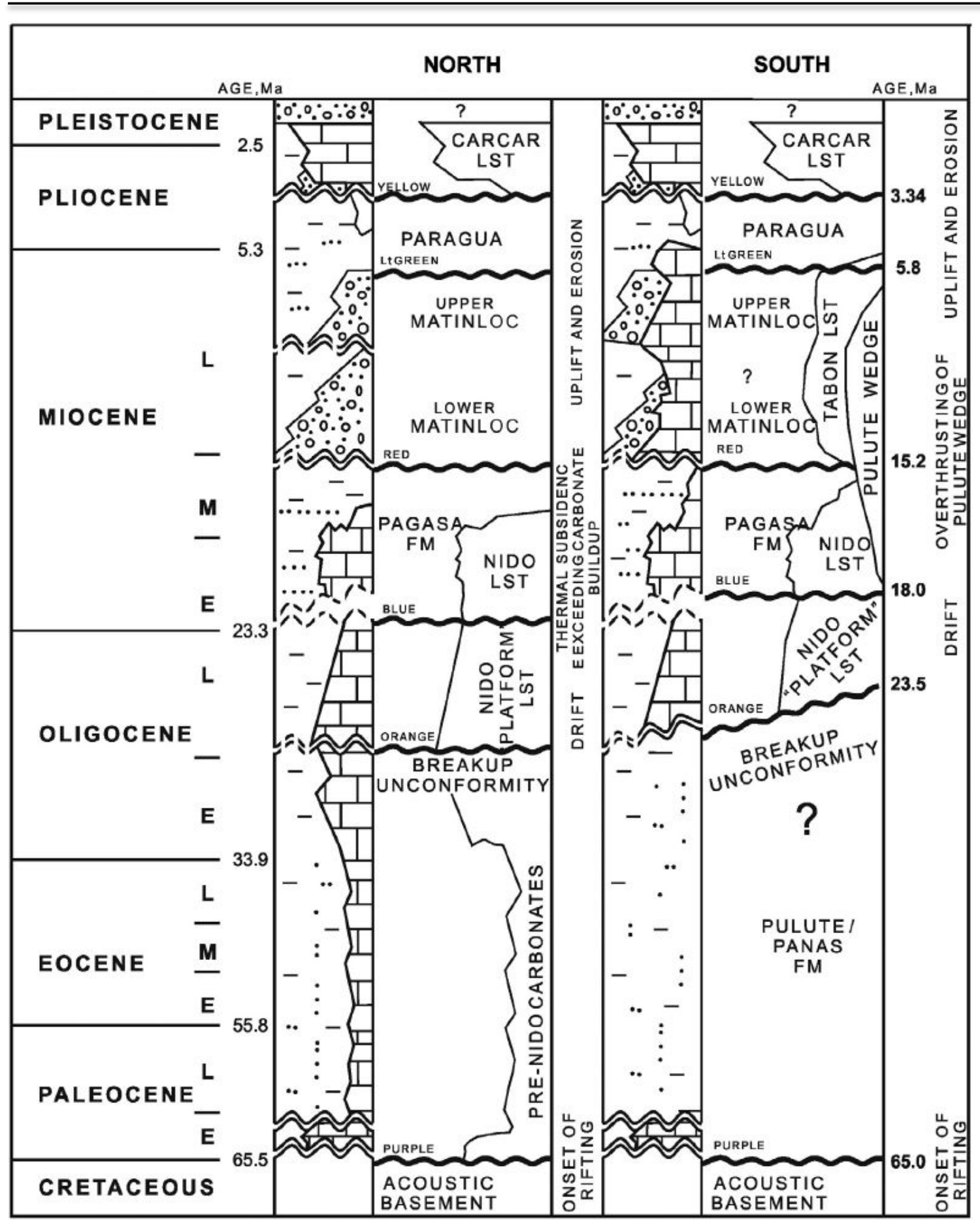

Figure 37: Generalized stratigraphic columns of the western Palawan shelf. Separate columns are given for the northern and southern part of the shelf. The ages for the boundaries between the epochs are taken from the International Stratigraphic Chart by the International Commission on Stratigrapy ICS, 2012 (www.Stratigraphy.org). Ages given on the right side next to the unconformities were derived from a biostratigraphic correlation. The main interpreted unconformities are highlighted and assigned the colors shown in the seismic sections. In addition the main tectonic events are also plotted to the columns. 


\section{Carbonates}

Well known carbonates in North Palawan are the some hundred meters thick St. Pauls limestones, massive reef-like carbonates, predominantly limestone in North Palawan (Aurelio, 2010; Wolfahrt et al., 1986). These limestones were dated Early Miocene by Wolfahrt et al. (1986), based upon foraminifera. According to these authors large parts of North Palawan must have seen a major uplift as the St. Pauls limestone is the youngest marine onshore deposit left by erosion.

The offshore equivalents of the St. Pauls limestones are the Nido platform carbonates (Figure 37). These limestones were frequently drilled and also interpreted on seismic section on the northwest Palawan shelf (e.g. (Franke et al., 2011; Grötsch and Mercadier, 1999)). Offshore, the development of carbonates started earlier, forming e.g. the Malampaya buildup. Grötsch and Mercadier (1999) proposed an age for the beginning of Nido deposition in the Lower Oligocene (Rupelian) based on Sr-isotope dating. They proposed a model in which the carbonate buildup started on the crest of tilted fault blocks. During the Late Oligocene and Early Miocene reef buildups developed on the highest parts of the platform keeping pace with a rapid relative sea level rise (Grötsch and Mercadier, 1999).

Samples from dredging on the Dangerous Grounds, south of Reed Bank indicate shallow marine carbonates (wacke-, pack-, boundstone) with ages from Late Oligocene to lower Middle Miocene (Kudrass et al., 1986).

While there is sufficient evidence for the continental composition of the crust of the North Palawan/Calamian area (e.g. (Berggren, 1995; Holloway, 1982; Letouzey et al., 1988; Suzuki et al., 2000; Taylor and Hayes, 1980; Zamoras and Matsuoka, 2004)) the crustal composition in central and South Palawan is ambiguous.

\section{Central and southern Palawan}

Central and southern Palawan is dominated by rocks of oceanic affinity. These show similarities with the northwestern part of Borneo. The most prominent lithologic unit onshore is the ophiolitic sequence that was thrusted onto the island. The lithologies and formations onshore central and south Palawan are as follows (Figure 38). 


\section{Cretaceous Ophiolites; "Basement"}

In central and south Palawan, and on the island of Balabac $\left(\sim 8^{\circ} \mathrm{N}, 117^{\circ} \mathrm{E}\right)$, the oldest sediments associated with ophiolitic rocks and pillow basalts are of Early Cretaceous age (Letouzey et al., 1988). These remnants of the Proto-South China Sea oceanic crust are believed to be also present in Sabah and Sarawak/Borneo (Hutchison, 2005a). Several authors suggested the ophiolites of Borneo to be the equivalents to the ophiolite complexes of south and central Palawan (Cullen, 2010; Rangin et al., 1990; Schlüter et al., 1996). Müller (1991) obtained Cretaceous nanoplanktons from calcareous red clays, associated with the pillow basalts in south Palawan and Balabac Island. The initiation of the consumption of this Proto-South China Sea oceanic basin likely took place in Middle Eocene times, around 44 Ma (Tongkul, 1991). Oceanic subduction evolved until collision (late Early Miocene to early Middle Miocene) when the Dangerous Grounds and NW Palawan microcontinental blocks entered the subduction zone (Concepcion et al., 2012; Cullen, 2010; Hutchison, 2010; Tongkul, 1991). Encarnacion (2004) derived an 39Ar/40Ar isochron age of 34 Ma (Late Eocene) from pillow basalts on southern Palawan. This age is commonly referred to as obduction age for the ophiolites (e.g. (Cullen, 2010)) and coincides with the Late Eocene obduction age of the Telupid ophiolites in central Sabah which were thrust over the Crocker Formation (Concepcion et al., 2012). Cullen (2010) therefore proposed that the Sarawak Orogeny was a regional Eocene to Early Oligocene event that extended from Sarawak, through central Sabah and into Palawan.

\section{Early Tertiary Espina formation.}

Wolfahrt et al. (1986) reported an Upper Cretaceous to ?Early Tertiary highly indurated shale with some limestone and spilitic basalt, and interbeds of chert (Espina FM). These authors proposed that the formation is widespread on south and central Palawan Island but only patchy remains of these rocks are found in central Palawan because vast areas of the island were overthrusted by ophiolites. Some larger areas are preserved in southern Palawan (Aurelio, 2010). Radiolaria determine a Late Cretaceous (top Campanian/base Mastrichian) age for the lower part of this formation (Almasco et al., 2000). Some foraminifera in the upper part of the formation suggest an Early Tertiary (?Paleocene) age. The Espina FM was suggested by Aurelio (2010) to represent the youngest unit of the Palawan ophiolites. In Figure 38 we combined the Espina Fm with the ophiolites into a single unit.

\section{Sedimentary cover}

The successions of sedimentary rocks in central and south Palawan are comparatively young and distinctly different from North Palawan (Wolfahrt et al., 1986). Metamorphic rocks, which cover wide areas in North Palawan are restricted to small patches in south and central Palawan (Wolfahrt et al., 1986). 
Eocene to Oligocene Panas (Pulute) Formation.

The Eocene to Lower Oligocene Panas Formation (or Pulute FM) consists of beds of arkose with intervals of mudstone and siltstone (Wolfahrt et al., 1986). Onshore it also comprises massive sandstones, shales and conglomerates (Aurelio, 2010). According to Schlüter et al. (1996) the Panas Formation is also present offshore, forming the major part of the northwestern accretionary wedge, adjacent to the Borneo-Palawan Trench and is correlative to the Crocker formation of Sabah.

The thrusted wedge is called Pulute formation in several well logs offshore W-Palawan. We follow this nomenclature even though the wedge development continued until the Upper Miocene, reworking the Eocene sediments and incorporating younger sediments (Middle Miocene) into the wedge front.

Oligocene to Miocene carbonates.

Little is known from the Early Miocene platform carbonates onshore and offshore south and Central Palawan. Wolfahrt et al. (1986) reported an Early Miocene massive, cross-fractured limestone (Ransang limestone) in southern central Palawan (Quezon area) which they consider as identical to the St. Pauls limestone from North Palawan. The carbonates are preserved on top of the ophiolites. Dating of the carbonates in the Quezon area $\left(09^{\circ} 10^{\prime} \mathrm{N} 118^{\circ} \mathrm{E}\right)$ by Rehm (2002) gave Middle Miocene ages of about 16.5 Ma (planktonic foraminifer zone N7) to $13.5 \mathrm{Ma}$ for these limestones. They started to develop at about the same time as the youngest dated Nido carbonates drowned. We question therefore the idea that these limestones are equivalents of the Nido limestone and suggest that these are rather part of a younger sequence, the Tabon limestone or Alfonso XIII Formation (Aurelio, 2010).

The Alfoso XIII Formation is known from the Quezon area in the southern part of central Palawan and the western coast of south Palawan. Formaninifera and nanofossils indicate a Late Miocene (or a ?late Middle Miocene to Late Miocene) age for the massive to bedded, mostly micritic packstone and wackestone (Wolfahrt et al., 1986). More recent dating by Rehm (2002) on this formation gave an age of late Middle Miocene. This study also showed that these carbonates onshore are getting younger towards the west. Age information collected near the base of this formation showed ages from 15 Ma to 13.5 Ma.

Offshore the Alfonso XIII Formation coevals with the Tabon limestone (Aurelio, 2010; Schlüter et al., 1996). 


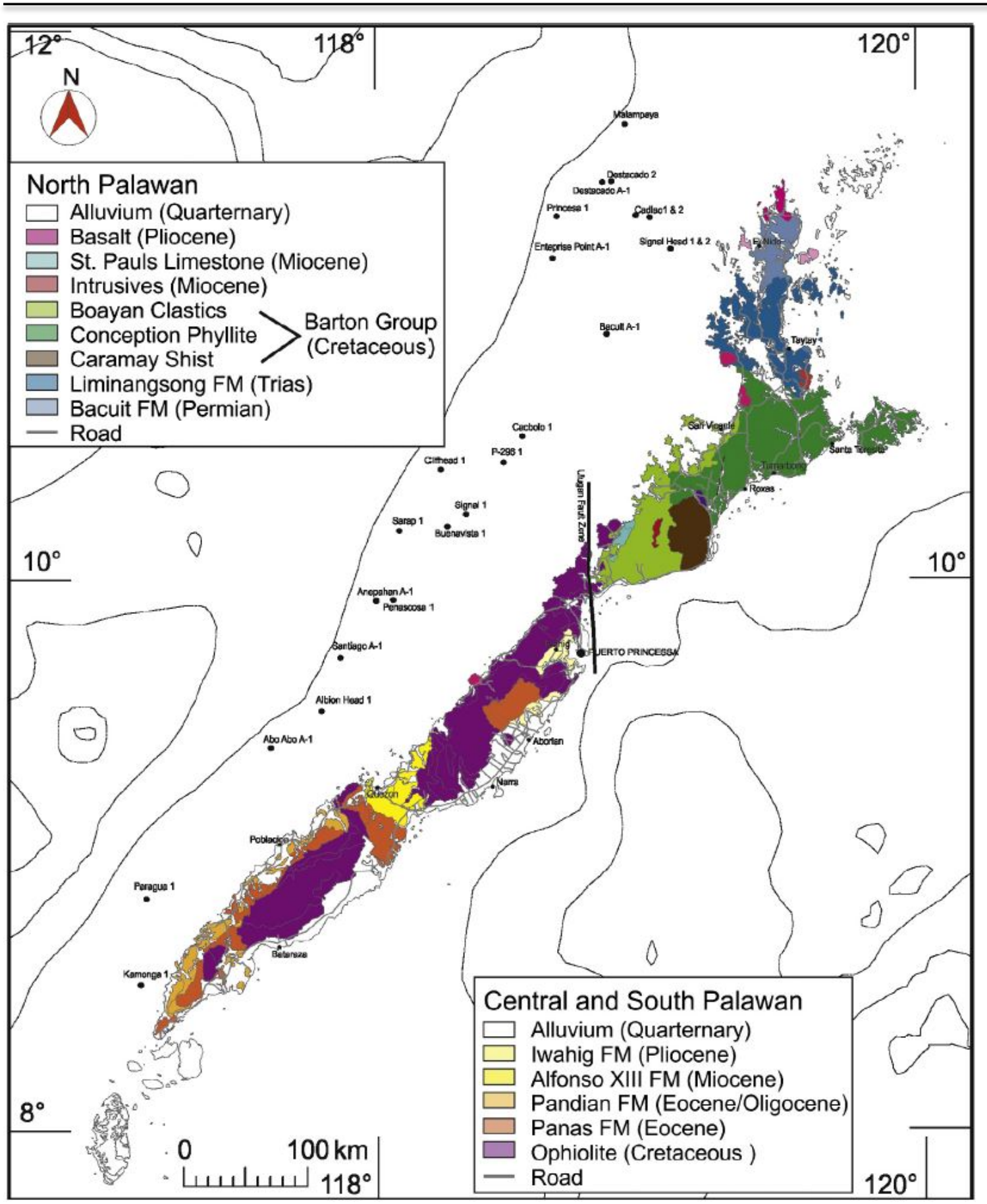

Figure 38: Geological map of Palawan Island adapted and modified from the JICA-MMAJ data and maps (1989). Offshore wells are indicated. The legend shows the main geological units of northern and central-south Palawan.

\section{Data base}

In the past 30 years more than 50 commercial wells were drilled offshore on the West Palawan shelf. Here we used data from the 15 best documented wells, 10 on the SW Palawan shelf and 5 on the NW Palawan shelf, for correlation and detailed investigation (Figure 36, Table 4 and Table 5). The 10 wells on the SW Palawan shelf are spread over $360 \mathrm{~km}$ along the shelf from the northernmost well P_296 at $10^{\circ} 17^{\prime} \mathrm{N}$ to the southernmost well Likas- 1 at $07^{\circ} 43^{\prime} \mathrm{N}$. For these 10 wells detailed biostratigraphic reports were available. In addition to the reports, well summaries, giving tentative 
ages were available for all wells. Five of these 10 wells penetrated the Tabon limestone. To interpret the extent of the Tabon limestone across the region a set of multichannel 2D seismic lines, acquired by BGR in the last 30 years, was used. For location of the seismic lines see Figure 40. Ages were assigned to the biostratigraphic zones according to the biostratigraphic correlation of the ODP-site 1148 on the northern South China Sea (Qianyu Li, 2004). Ages for about 25\% of the biomarkers which were not dated in the ODP-site 1148 were assigned according to age data given by Berggren (1995).

From the biostratigraphic reports zones of planktonic foraminifera assemblages were identified and the tops of these foraminiferal zones were defined as biostratigraphic markers. Biostratigraphic zones in the well data range from N2 (top is $26 \mathrm{Ma}$ ) to N22 (top is $1.8 \mathrm{Ma}$ ). Figure 39 shows the well data with the identified biostratigraphic zones for each five wells on the NW and SW shelf. For better visibility the Tabon limestone, the Nido limestone and the Pulute Formation are highlighted by shading.

\section{Interpretation}

\section{Oligocene to Early Miocene platform carbonates, the Nido carbonates}

The Nido carbonates comprise both platform carbonates and reefs growing on top of these platforms (Figure 37 and Figure 45). The carbonate platform is widespread in the Palawan-Borneo trough and on the NW-Palawan shelf (Figure 40). Since the reefs on top of the platform started and ended their development at different times we used only the Nido carbonate platform for dating. Depth and age of the Nido carbonates for each well are given in Table 4.

\section{Distribution of Nido limestone}

Based on 2D-seismic data, tied to wells a depth-structure map at the top of the Nido platform carbonates is presented in Figure 40. The lateral extent of the continuous Nido carbonate platform as plotted on the map is well constrained by seismic lines at its western and northern boundary. Towards the south the platform continues to offshore Sabah. Due to the decreasing resolution of the seismic lines close to the Palawan shore it is not possible to define the eastern boundary of the platform underneath the thrusted wedge. The western limit of the platform carbonate was interpreted on reflection seismic data only. Only areas with a distinct low-frequency pattern, indicating the presence of such carbonates are indicated in Figure 40. However, such reflection pattern may change to a more regular image when the platform becomes thinner and we may have missed some areas still being covered by carbonates. Thus this figure indicates a minimum extend of the platform carbonates. Smaller, isolated carbonates of Oligocene to Early Miocene age are also present in the Dangerous Grounds but not shown in Figure 40. 
Chapter 4: Time constraints on the evolution of Southern Palawan Island, Philippines from onshore and offshore correlation of Miocene Limestones

Table 4: Depth and age of the Nido Limestone

\begin{tabular}{|c|c|c|c|c|c|c|c|c|}
\hline Well name & $\begin{array}{l}\text { Depth top } \\
\text { Nido (m) }\end{array}$ & Age top Nido & $\begin{array}{l}\text { Age top Nido } \\
\text { (Ma) }\end{array}$ & $\begin{array}{l}\text { Depth base } \\
\text { Nido (m) }\end{array}$ & Age base Nido & $\begin{array}{l}\text { Age base } \\
\text { Nido (Ma) }\end{array}$ & TD & $\begin{array}{l}\text { Base } \\
\text { drilled }\end{array}$ \\
\hline Busuanga & 1600 & Late Oligocene & 26.00 & 1857 & Early Oligocene & 32.40 & 1857 & \\
\hline Busuanga (Nido Reef) & 1341 & Early Miocene & 17.00 & & & & & \\
\hline Nalaut & 1410 & Late Oligocene & 22.50 & 1524 & Late Oligocene & 24.30 & 1524 & \\
\hline Galoc-1 & 2357 & Early Miocene & 16.40 & 3634 & Late Oligocene & 24.70 & 3700 & yes \\
\hline Cadlao-1 & 2298 & Early Miocene & 22.60 & 2634 & Late Oligocene & 25.70 & 3295 & yes \\
\hline Cadlao-1 (Nido Reef) & 1720 & Early Miocene & 16.40 & & & & & \\
\hline Enterprise Point A-1x & 2222 & Middle Miocene & 14.50 & 2598 & Early Miocene & N.A. & 2598 & \\
\hline Catalat-1 & 2631 & Early Miocene & 19.00 & 4037 & Late Oligocene & 25.00 & 4362 & yes \\
\hline P_296 & 2868 & Early Miocene & N.A. & 3025 & Early Miocene & N.A. & 3025 & \\
\hline \multicolumn{9}{|l|}{ SW-Palawan shelf } \\
\hline Penascosa-1 & 3215 & Middle Miocene & 15.20 & 3706 & Early Miocene & N.A. & 4267 & yes \\
\hline Anepahan & 2603 & Early Miocene & 16.40 & 2743 & Early Miocene & N.A. & 2743 & \\
\hline
\end{tabular}

Table 5: Depth and age of the Tabon Limestone

\begin{tabular}{|l|l|l|l|l|l|l|}
\hline Well name & $\begin{array}{l}\text { Depth top } \\
\text { Tabon }(\mathrm{m})\end{array}$ & Age top Tabon & $\begin{array}{l}\text { Age top } \\
\text { Tabon (Ma) }\end{array}$ & $\begin{array}{l}\text { Depth base } \\
\text { Tabon (m) }\end{array}$ & $\begin{array}{l}\text { Age base } \\
\text { Tabon (Ma) }\end{array}$ \\
\hline AboAbo A1-x & 1252 & Lower Late Miocene & 7.45 & 1445 & Lower Late Miocene & 9.2 \\
\hline Kamonga-1 & 840 & Lower Late Miocene & 7.34 & 1045 & Lower Late Miocene & 9.2 \\
\hline Murex-1 & 979 & Upper Late Miocene & 5.5 & 1169 & Upper Late Miocene & 6.8 \\
\hline Paz-1 & 728 & Lower Pliocene & 4.6 & 1057 & Lower Late Miocene & 9.2 \\
\hline Likas-1 & 740 & Lower Pliocene & 4.35 & 1137 & Lower Late Miocene & 7.8 \\
\hline
\end{tabular}

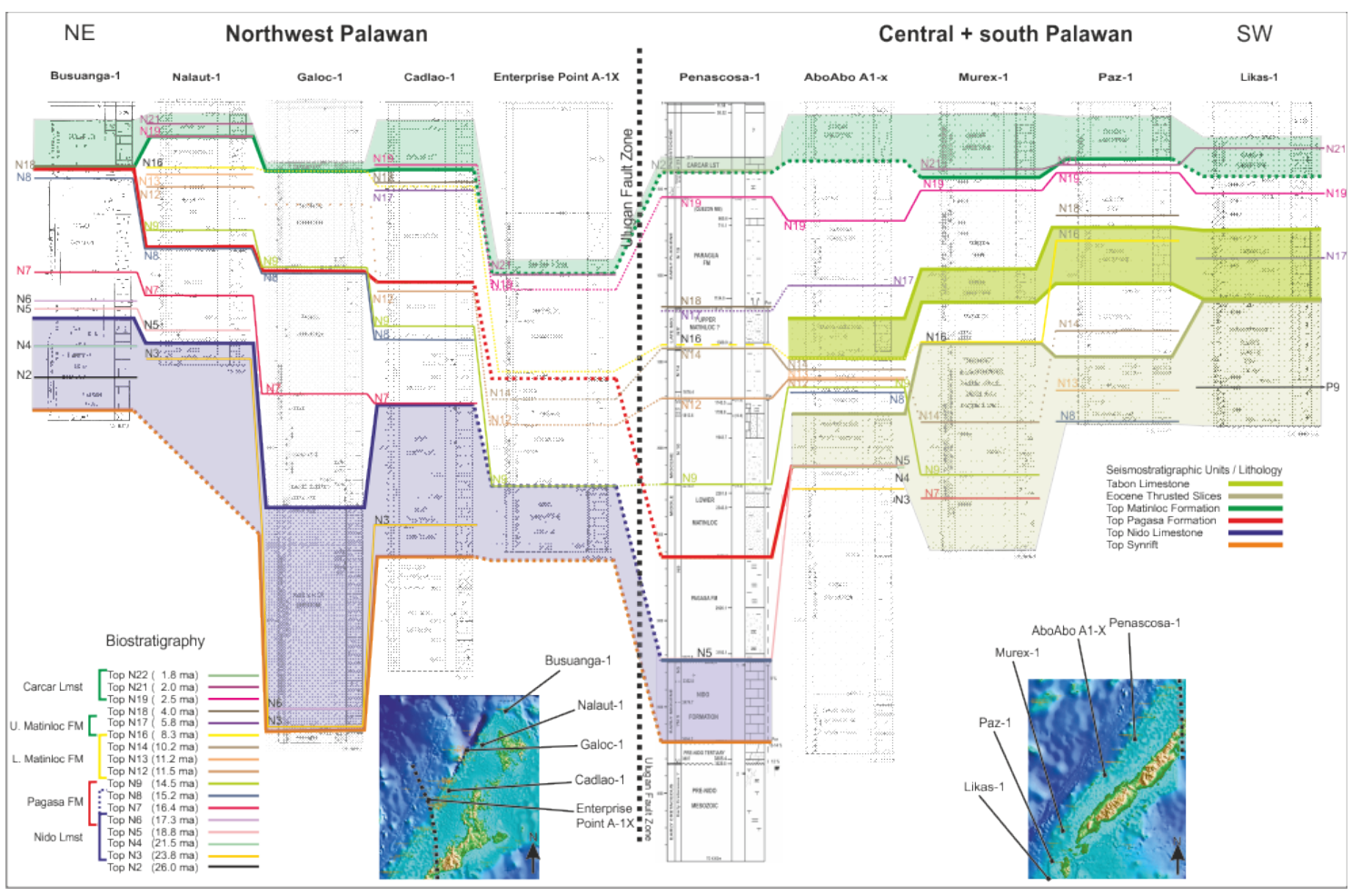

Figure 39: Correlation chart of ten selected wells offshore west Palawan. Superimposed on the lithologs of the wells the tops of planktonic foraminifera zones are shown. The assigned ages for these formation tops are given in the legend. The three main formations (Tabon limestone, Nido limestone and the thrusted wedge) are highlighted by shaded background. The location of the wells is given on the small inset maps and on Figure 36 and Figure 38. The inferred position of the Ulugan Fault Zone is drawn as a dotted black line. 
In the Reed Bank area the time equivalent of the Nido limestones was drilled at depths of $\sim 1700 \mathrm{~m}$. Well logs show a continuous deposition of carbonates since the Oligocene on Reed Bank. This is likely related to the fact that the Reed Bank is a relatively stable block which subsided less than the surrounding area, but was continuously submerged since the Oligocene.

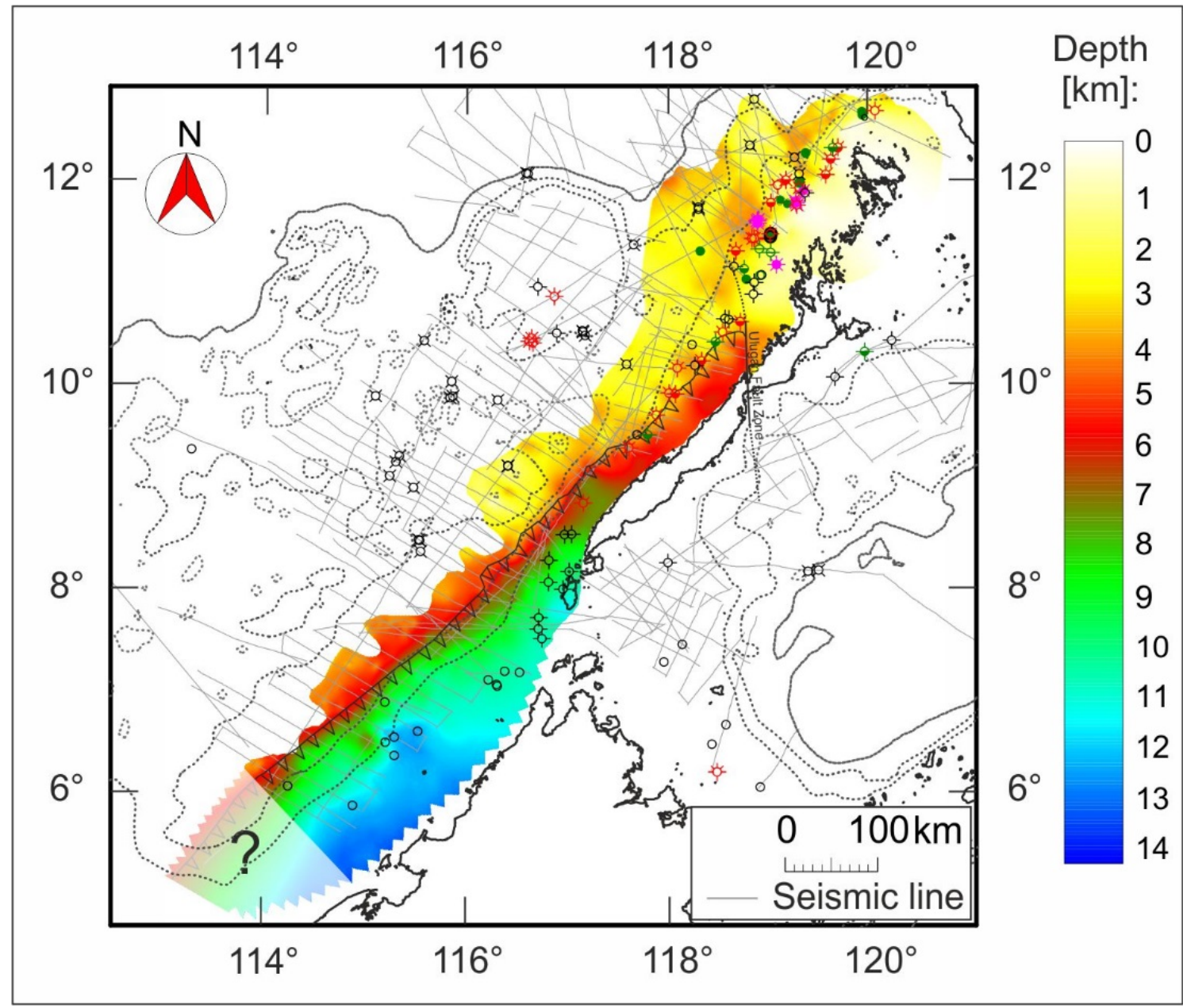

Figure 40: Depth of the Top Nido platform carbonates. Thick solid lines indicate the coastline and $100 \mathrm{~m}$ depth contours are shown as dashed lines. The inferred position of the Ulugan Fault Zone and the outline of the thrusted wedger are indicated. Gray lines indicate the reflection seismic dataset used for the regional interpretation of the platform carbonates. This map shows the outline of the continuous Nido platform. Isolated carbonates occur also on the Reed Bank and in the Dangerous Grounds. The color code of the legend ranges from very shallow (bright yellow) to deep (blue).

Offshore north Palawan, to the northeast of the proposed Ulugan Fault Zone, the carbonates are generally at shallow depth and dip towards the west (Figure 40). From a depth of about $3.5 \mathrm{~km}$ (orange) at $\sim 11.5^{\circ} \mathrm{N}, 118.5^{\circ} \mathrm{E}$ they rise to less than $0.5 \mathrm{~km}$ (bright yellow) close to the shore and crop out onshore northern Palawan.

Off the coast of central and south Palawan the Nido limestones dip in the opposite direction, towards the southeast. The depth increases from $\sim 1.5 \mathrm{~km}$ (yellow) at $\sim 9^{\circ} \mathrm{N}, 116^{\circ} \mathrm{E}$ to more than $8 \mathrm{~km}$ (green) at $\sim 8^{\circ} \mathrm{N}, 117^{\circ} \mathrm{E}$, or even more offshore Sabah.

This dipping is likely caused by the down bending of the Dangerous Grounds plate due to the loading effects by the thrusted wedge. 
The trend of the Ulugan Fault Zone may be inferred from a rapid depth change of the carbonates at $10.5^{\circ} \mathrm{N} 118.8^{\circ} \mathrm{E}$.

The seismic data indicate that at least wide parts (if not all) of the downgoing plate beneath south and central Palawan are covered by carbonates which likely are equivalents of the Nido limestone as found on the northwest Palawan Shelf.

\section{Age for the base of Nido limestone}

The onset of the Nido limestone deposition was controlled by pre-Nido extensional deformation leading to a rugged seafloor relief. The carbonates started to develop at the highest points of the seafloor (Grötsch and Mercadier, 1999). For three wells offshore North Palawan age information near the base of the Nido platform carbonates are available. These ages are upper Late Oligocene ( $25 \mathrm{Ma}$ ). The calculated ages range from 24.3 Ma (Nalaut-1 well) to 24.7 Ma (Galoc-1 well). The top of foraminiferal zone N3 (23.3 Ma) could be identified in the Cadlao-1 well, about $40 \mathrm{~km}$ west of North Palawan, at about $180 \mathrm{~m}$ above the base of the limestones. We therefore calculated an age of about 25.7 Ma for the onset of carbonate sedimentation (see Table 4).

In five wells offshore north Palawan age information within the Nido succession are available (Table 4). These ages range from the Early Oligocene (zone O3/N1 (top is $29.4 \mathrm{Ma}$ )) to the lower Early Miocene (zone N4 (top is $21.5 \mathrm{Ma}$ )). The oldest marker (top O3) is located $\sim 800 \mathrm{~m}$ above the base of the limestones. Due to thrust tectonics in the area of this well the true thickness of the limestones is difficult to determine. In the Busuanga-1 well $60 \mathrm{~km}$ north of the previously described the top of zone N2 (26 Ma) is located $~ 200 \mathrm{~m}$ above the base of the limestone giving an age of Early Oligocene (32 Ma).

\section{Age for the top of Nido limestone}

The deposition of the Nido carbonates ceased with the drowning of the carbonates in the early Early Miocene (Aquitanian-Burdigalian) and the carbonate buildups were sealed by Early to Middle Miocene basinal Pagasa clastics (Fournier et al., 2005; Williams, 1997). With the data at hand it is not possible to assign a specific age to the top of the carbonates. ${ }^{87} \mathrm{Sr} /{ }^{86} \mathrm{Sr}$ dating of a sample in the Malampaya field offshore northwestern Palawan indicate a drowning age of the Nido Carbonates of about $20 \mathrm{Ma}$ (Grötsch and Mercadier, 1999). Two additional samples at the base of the Pagasa formation yielded dates of 15.1-13.7 Ma and 18.8-17.3 Ma respectively (Grötsch and Mercadier, 1999). The youngest reef buildup was drilled by the well Enterprise Point $\sim 1100 \mathrm{~km}$ off the coast of North Palawan where the top of foraminiferal zone N8 (15.2 Ma) occurs only $1 \mathrm{~m}$ above the top of the limestone, confirming in some places the reef buildup continued until the early Middle Miocene (Williams, 1997). A reef of similar age is shown in Figure 47 at $5 \mathrm{~km}$ offset.

We found no outcrop or reference claiming the existence of equivalents of the Nido carbonates onshore south and central Palawan. 
In the wells offshore central Palawan the dating of the Nido carbonates is not straight forward due to the general poor occurrence of indicative fossils. Only in the well Penascosa- 1 the top of foraminiferal zone N8 (top is $15.2 \mathrm{Ma}$ ) was identified four meters above the top of the Nido limestone (Figure 39). In addition, most wells penetrated only reef buildups above the platform carbonates. These reefs ended their development in the Early Miocene (16.4 Ma) in the Anepahan1 well and in the Middle Miocene (15.2 Ma) in the nearby Penascosa-1 well (see Figure 36 for location). As locally reef growth continued when the deposition of the platform carbonates had terminated throughout the area these young ages may be misleading in defining when the deposition of the Nido carbonates ceased. Since we focused on the ages of the carbonate platform, we did not take these younger ages of the reefs into consideration.

In two wells (Anepahan-1 and Penascosa-1) off the coast of central Palawan Nido limestones were drilled and easily correlated with a distinct unconformity in the seismic data.

On the seismic data, the platform carbonate sequence exhibits subparallel reflections of high continuity and low frequency content. The top of these limestones is clearly visible in the seismic data as a distinctive positive reflector and can be traced also offshore central and south Palawan, and further into the Dangerous Grounds area west of Sabah (Figure 40).

\section{Age and stratigraphy of Tabon limestone}

\section{Extent and stratigraphy}

In the offshore area the Tabon limestone was exclusively deposited on the thrusted wedge in front of south and central Palawan (Figure 43). To the north it can be confidently traced in the seismic data to $\mathrm{N} 10^{\circ} 25^{\prime}$. To the south the extent of the Tabon limestone is not unequivocally clear. In the seismic data the Tabon limestone can confidently be traced to N09 $17^{\prime}$, but it was confirmed by the

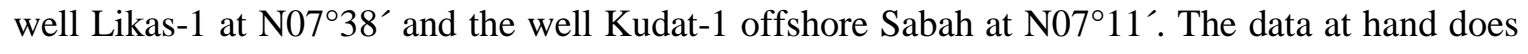
not allow defining the southern extent of the Tabon limestone more precisely. The Tabon limestone is interbedded in horizontally to subhorizontally layered fine clastic sequences. It is overlain by the clayish to very fine sandy Matinloc Formation (top is 7.8 Ma) or the Quezon Marl and below there is occasionally a succession of the fine-sandy/clayish lower Matinloc Formation. This lower Matinloc Formation reaches its greatest thickness of $\sim 200 \mathrm{~m}$ in the westernmost well (Murex-1). In the other wells offshore central and south Palawan the Lower Matinloc Formation below the Tabon limestone reaches thicknesses of at maximum 55 m (e.g. Kamonga-1). The depth of Tabon limestone for all wells is given in Table 5. The Lower Matinloc Formation probably originated from erosion of the onshore area further towards the east. The latter sediments lie unconformable on top of the accreted wedge. 


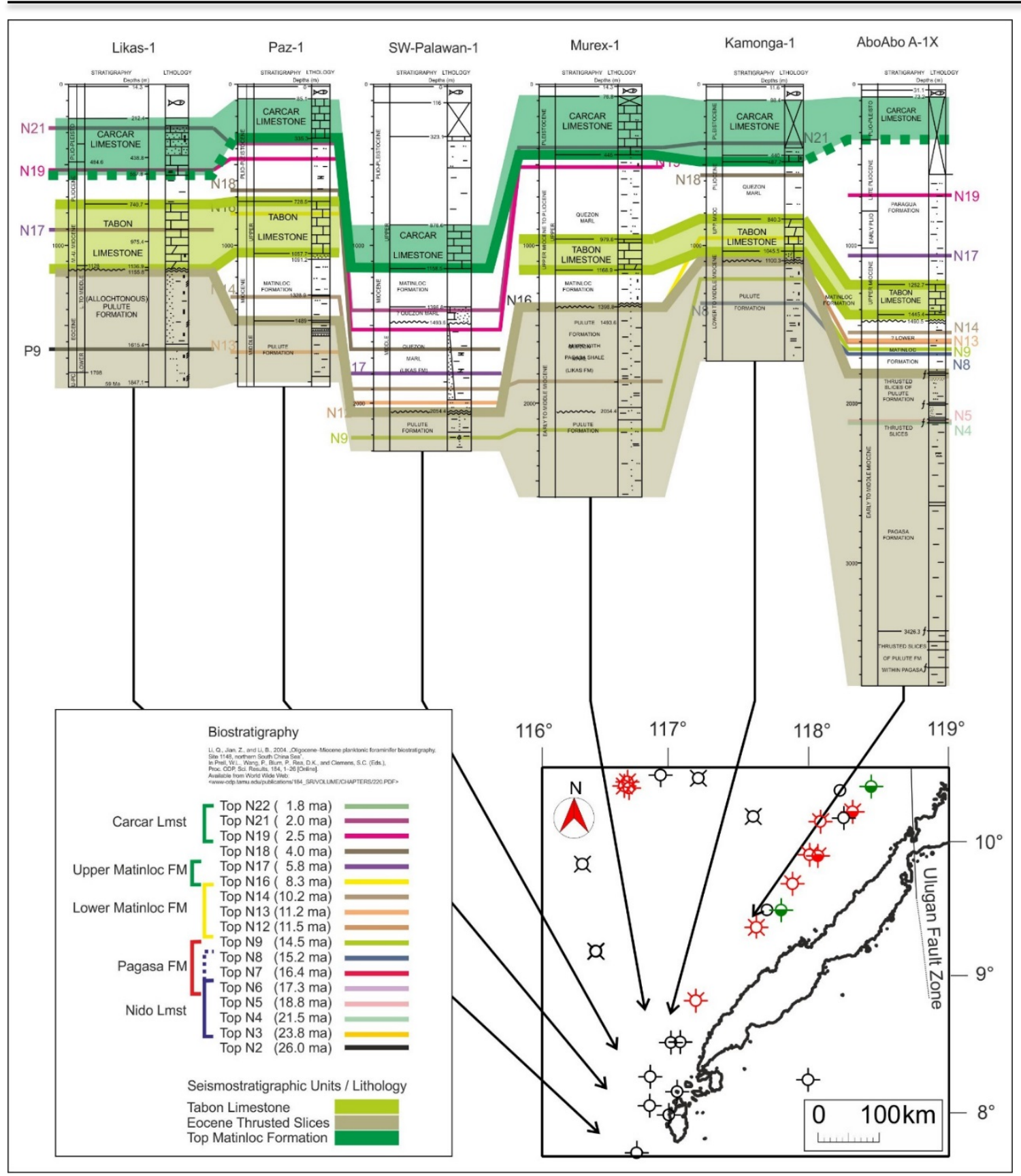

Figure 41: Correlation chart of five wells that penetrated the Tabon limestone offshore SW-Palawan. The tops of foraminiferal assemblage zones are superimposed shown on the lithologs of the wells. The Tabon limestone and the accretionary wedge are highlighted by shaded background and the ages of the formation tops are given in the lagend. The insert map shows the position of the wells on the shelf (see also Figure 36).

Rehm (2002) found that the late Middle Miocene carbonates outcropping in the southern part of central Palawan (shaded areas in Figure 43) are getting younger at their base from east (16.5 Ma) to west (12 Ma) over a distance of $4-5 \mathrm{~km}$. Using the biostratigraphic data from five offshore wells that drilled through Tabon limestone (Figure 41, Figure 43 and Table 5) this younger-westward trend can be extended for $45 \mathrm{~km}$ across the offshore area. The age determination for the Tabon limestone is exemplarily described for the Paz-1 well (Figure 36 and Figure 41): The thickness of the Tabon limestone in this well is $330 \mathrm{~m}$. There is one biostratigraphic marker (top N16; 8.3 Ma) within the Tabon limestone sequence in this well. The neighboring biostratigraphic markers at 
shallower and greater depth, which are top N18 (4 Ma) and top N14 (10.2 Ma) are present in the sandy sediments overlying and underlying the carbonates.

The question is about how to determine the age when the carbonate sedimentation started and terminated. Our approach was to calculate average sedimentation rates for both, the clastic sediments and the carbonates. The calculated sedimentation rate for the carbonates of $1 \mathrm{~mm} / \mathrm{year}$ is well within the average growth potential of carbonate platforms and reefs (Schlager, 1981). Effects of compaction were not taken into account for this calculation. As these calculation bear some uncertainties we have marked the calculated ages as dashed lines in Figure 42.

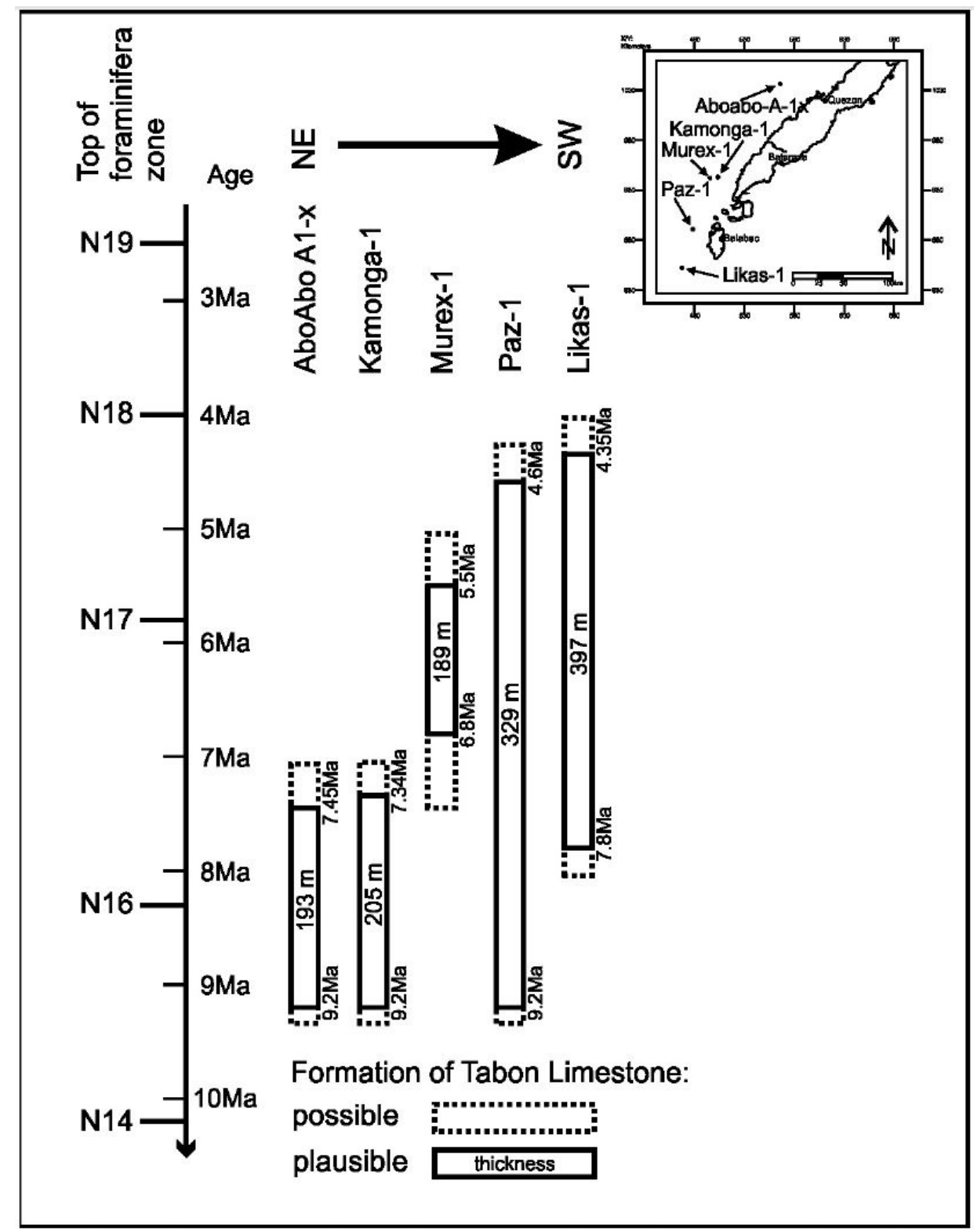

Figure 42: Deposition scheme of Tabon limestone. Bars indicate the measured (solid) and Calculated (dashed) deposition times for the limestone. The thickness of the limestones is given for each well. Inset map shows the position of the wells on the shelf. 


\section{Age for the base of Tabon limestone}

The initial development of the Tabon limestone was found to be diachronous across the SW Palawan Shelf. The scarcity of seismic lines and well information did not allow a continuous interpretation of the Tabon limestone across the SW Palawan Shelf. The northern and southern parts in contrast are well underpinned by seismic lines (shaded area in Figure 43), but we suggest that the Tabon limestone is also present in the area in between.

Onshore the oldest Tabon limestones (late Early Miocene; 16 Ma) were found approximately 4 $\mathrm{km}$ from the coastline in the Quezon area (Rehm, 2002). Directly at the coast late Middle Miocene to early Late Miocene ( 13 Ma) carbonates crop out.

The Tabon limestones onshore coincide roughly with the tops of Zones N11 (13.2 Ma) and N7 (16.5 Ma).

In the Aboabo-A-1x well, about $30 \mathrm{~km}$ off the coast of Central Palawan $\left(9^{\circ} 23^{\prime} \mathrm{N} 117^{\circ} 36^{\prime} \mathrm{E}\right)$ the Tabon limestone deposition started in the early Late Miocene ( $\sim 9 \mathrm{Ma})$. This shows a trend to young in westward direction for the onset of carbonate deposition.

Further south, about $35 \mathrm{~km}$ southwest of the coast of Balabac Island $\left(7^{\circ} 43^{\prime} \mathrm{N} 116^{\circ} 42^{\prime} \mathrm{E}\right)$ the Tabon limestone started growing in the early Late Miocene ( 8 Ma; Likas-1 well). The youngest drilled carbonates of the Tabon limestone formation were found at the Murex-1 well, $30 \mathrm{~km}$ off the coast of south Palawan. In this well no top of a foraminiferal zone could be identified within the Tabon limestone section. By extrapolating the age, using the calculated sedimentation rate, we suggest a late Late Miocene age ( 7Ma) for the beginning and also late Late Miocene ( 5 Ma) for the end of the deposition of the Tabon limestone here. Thus, there is again an age trend showing successive younger carbonates in westward direction between the wells Kamonga-1 and Murex-1. In the Kudat-1 well $63 \mathrm{~km}$ south of Likas-1 the Tabon limestone has Tortonian (Late Miocene) nanoplankton, which is in accordance with the age of the Tabon limestone in the Likas-1 well.

The temporal and spatial transgressive development of Tabon limestone is probably linked to tectonic activity during the formation of the wedge. We propose that pulses of uplift from the southeast towards the northwest brought the top of the wedge progressively into shallow water conditions, allowing the carbonates to grow. This uplift started in the eastern, now onshore, part of central Palawan where the Tabon limestone is found to directly overlie the ophiolites. Here, the limestones are dated as late Early Miocene (Rehm, 2002). A general rise in sea level between 10 and 5Ma (Haq et al., 1987) likely provided the space for the further growing of the limestones. However, as the top of the wedge is widely horizontal we exclude sea level variations as main explanation for the westward migrating carbonate deposition. Assuming a tectonically stable area which is already partly under subaerial conditions (central Palawan with the onshore Tabon limestone) a rise of the sea level would result in a transgression towards the east. 


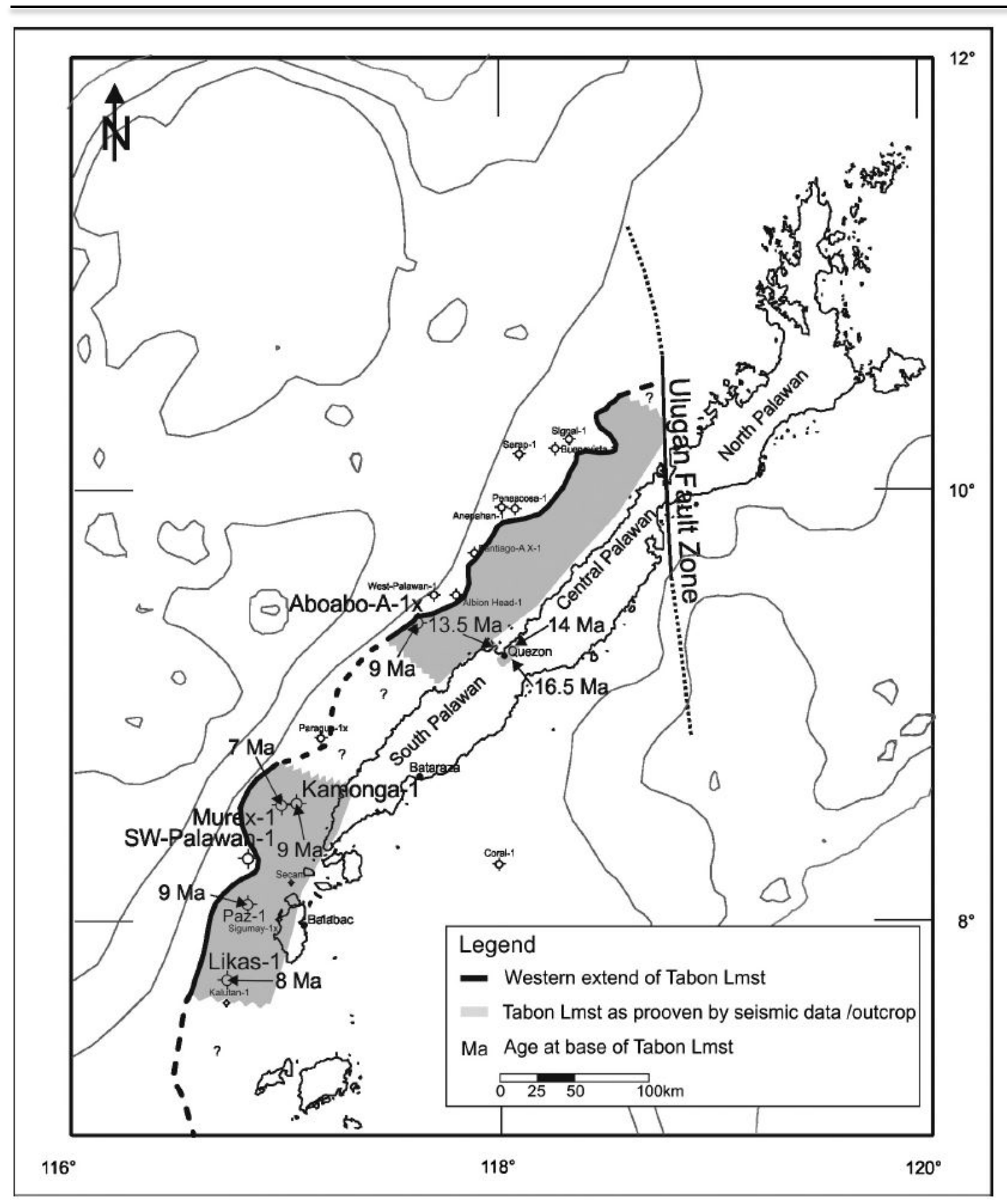

Figure 43: Distribution of Tabon limestone on the western Palawan shelf. Areas with proven occurences of the limestones are shaded. Onshore outcrops near the city of Quezon are also shaded. Ages are given for the oldest parts of Tabon limestone at different locations.

In this case the deposition of carbonates and the development of reefs would start in the west in the shallow water and then propagate eastward, but the contrary is the case. We thus propose that a tectonically induced uplift of the wedge in front of central and south Palawan provided progressively shallower water conditions, allowing the Tabon limestone to prograde towards the west. 


\section{Age for the top of Tabon limestone and end of deposition}

The limestone sedimentation may have finished as result of either a slow retreat of the carbonates or their rapid drowning. The area around the Paz-1 and Likas-1 wells offshore Balabac Island in the south and the area of Murex-1 and Kamonga-1 offshore southern Palawan show different developments of the Tabon limestone. In Murex-1 and Kamonga-1 the Tabon limestone is overlain by marls. This indicates a retreat of the reef probably towards the west. Offshore southern Palawan this retreat terminated the Tabon limestone development first in the Kamonga- 1 well in the lower Late Miocene (Tortonian). Around the same time the deposition of Tabon limestone started in the Murex-1 well $8 \mathrm{~km}$ further towards the west and went on until the upper Late Miocene (Messinian) before here the carbonates were also overlain by marls.

To the southwest of Balabac Island, the rocks overlying the limestones are predominately claystones. This indicates deep water conditions and therefore a much faster drowning of the Tabon platform in this area. We derive an end of the carbonate sedimentation at 4.6 Ma (Paz-1) and 4.4 Ma (Likas-1). We thus propose that the platform drowned in both places southwest of Balabac Island more or less simultaneously in the lower Early Pliocene.

Similar to the Kamonga- 1 well offshore South Palawan, in the Aboabo A-1x well offshore Central Palawan the deposition of Tabon ended at around $7 \mathrm{Ma}$, but here the platform drowned quickly and the carbonates were overlain by clays. The fast drowning of the platform in central Palawan is possibly linked to a local gravitational collapse at the wedge front, leading to rapid extension and subsidence. We could identify at least two separate areas where such a collapse took place. It is clearly visible along several seismic lines across the wedge and is shown exemplarily in Figure 44 and Figure 46.

\section{Structure of the Tabon limestone}

The Tabon limestone can be traced offshore towards the west until close to the edge of the wedge in front of Palawan. The seismic images (e.g. Figure 46) show clearly that the Tabon limestone is not affected by the thrusting of the wedge in the offshore area. It lies undisturbed and unconformable on the thrusted rocks of the wedge, showing horizontal to subhorizontal internal reflectors. Only at the far western edge of the wedge, the Tabon limestone is affected by a late extensional deformation at the wedge front. This extension is most probably caused by gravitational collapse or sliding of the wedge front. The general mechanisms of collapse at the front of a thrusted wedge are described exemplarily by Moores and Twiss (1995). This localized extension fits together with the rapid facies change from shallow water carbonates to deep marine clays as observed in several wells. Onshore the equivalent of the Tabon limestone, overlying the ophiolites of Mesozoic age is heavily folded. This folding resulted in a large anticline with a ridge-axis oriented in NE-SW-direction in southern central Palawan. In fact the topography of the whole South Palawan Island reflects that anticline. The folding took place after the deposition of the Tabon 
limestone in that area. The youngest samples of this limestone in the Quezon area are dated upper Middle Miocene, so the uplift and folding must be younger.

\section{Discussion}

From a detailed interpretation of the seismic lines and a close examination of the biostratigraphic data available, we could conclude constraints for the development of the limestone formations and the Panas/Pulute wedge.

\section{Nido limestone}

Variations in the structure and evolution of Palawan Island are mirrored by the distribution of the Nido limestone. Offshore North Palawan these limestones show a general west-dip and finally crop out onshore (Figure 47). Offshore central and south Palawan, the Nido limestone platform dips eastward and is overthrusted by the Panas/Pulute wedge in front of Palawan and the Crocker wedge in front of Sabah (Figure 44 and Figure 45).

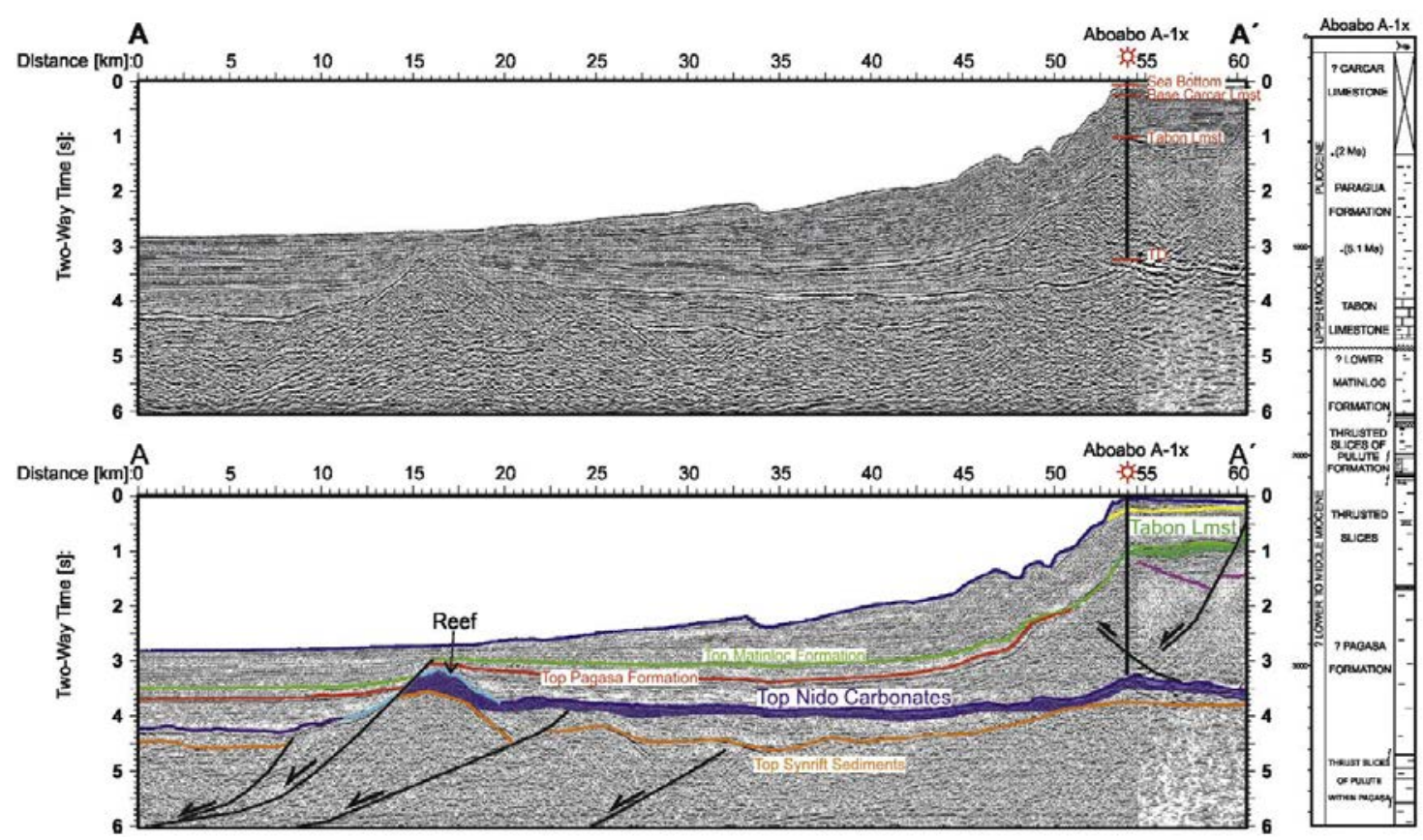

Figure 44: Reflections seismic profile A-A', running across the Palawan-Borneo Trough and the accretionary wedge offshore southern Palawan. In the interpreted section (bottom) the main unconformities are shown. (color code is given in Figure 37). The rifted half-graben structure of the Palawan-Borneo Trough is shown in the central and left part, the thrusted wedge is visible on the right side. The full litholog of the well is given on the right, next to the seismic line. The location of the profile is shown in Figure 36. 

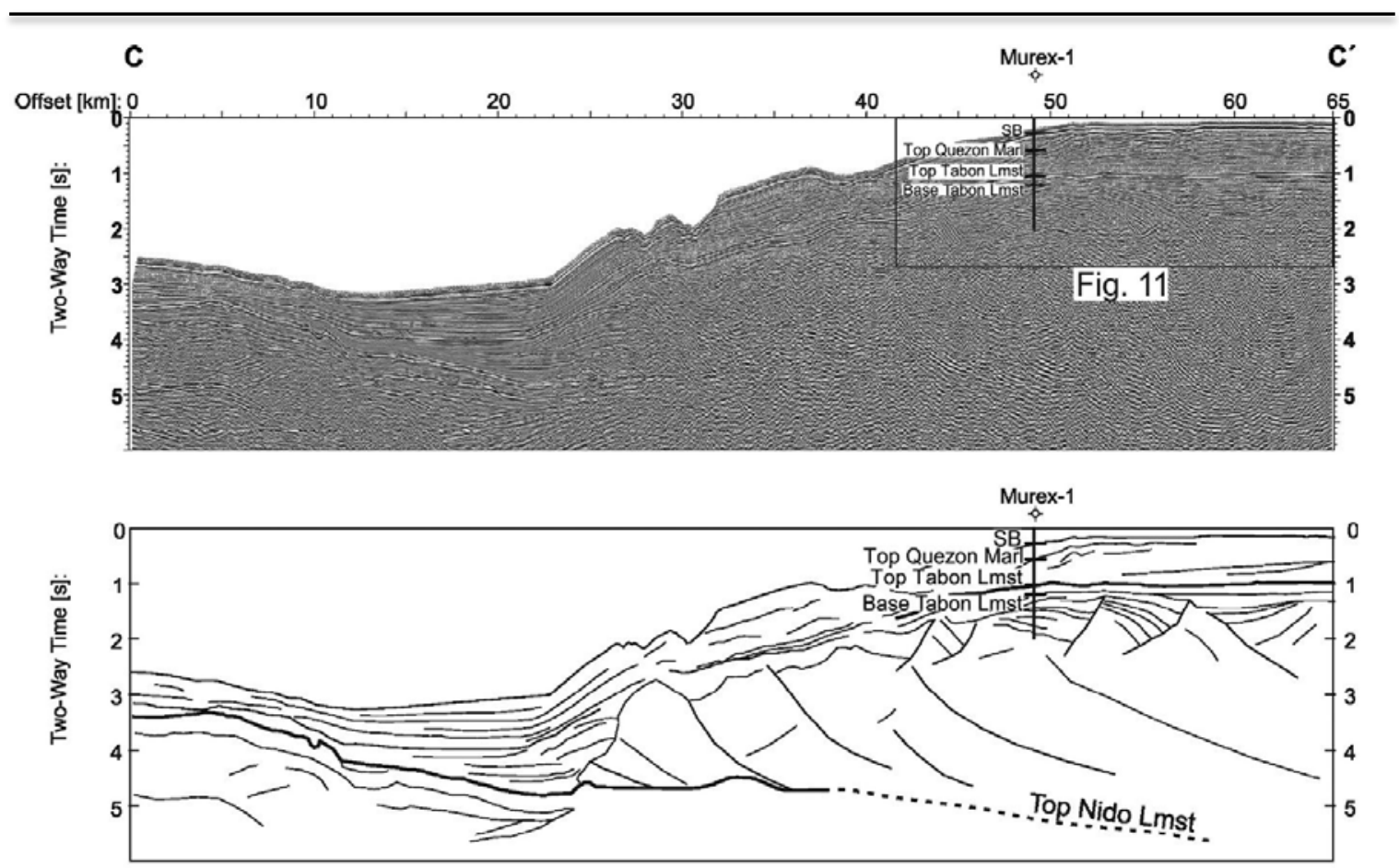

Figure 45: Reflection seismic profile $C-C^{\prime}$, running across the Palawan-Borneo Trough and the accretionary wedge between southern Palawan and Balabac Island. This line illustrates the structure of the thrusted wedge and the two limestone formations, the Nido and the Tabon. The position of the profile is shown in Figure 36. Top: not interpreted seismic; bottom: Line-drawing interpretation with limestones highlighted by bold lines. The reference well Murex-1 was projected from a distance of approximately $15 \mathrm{~km}$ onto the line. The inferred position of the Nido limestone underneath the wedge is indicated by a dashed line due to the strong decrease in seismic resolution underneath the wedge. The rectangle indicates the position of the enlarged section shown in figure 37

In the Catalat-1 well, slightly north of the Ulugan Bay in northern Palawan the top of the Nido limestone is drilled at a depth of $1.65 \mathrm{~s}$ TWT (2630 m). In the next seismic line, about $27 \mathrm{~km}$ further south the distinct reflector - associated with the top of the Nido limestone - is at 3.14 s TWT ( 4600 m) and the platform dips east. In between the supposed Ulugan Fault Zone must be located, yet no trace of this fault zone can be observed in our seismic data. Modest variations in the magnetic signal across the NW Palawan shelf (Ishihara and Kisimaoto, 1996) may indicate the prolongation of the Ulugan Fault Zone from north of Ulugan Bay into NNW-direction.

\section{Relationship between the Nido, Tabon, and Pulute Formations}

\section{Nido and Tabon relationship}

Our data show that the Nido platform carbonates were deposited before the Middle Miocene. Thus, Middle Miocene and younger carbonates in the Quezon area in central Palawan are rather the Tabon limestone and not the St. Pauls (Nido) limestone. This has been proposed earlier by Rehm (2002).

\section{Nido and Panas/Pulute relationship}

Seismic images (Figure 44 and Figure 45) show clearly that the Nido platform was, after its deposition, overthrusted by the Panas/Pulute wedge. The Nido platform was not or only mildly affected by the thrust tectonics indicating a detachment at the top of the carbonates or slightly above. 


\section{Tabon and Panas/Pulute relationship}

The thrusting and development of the Panas/Pulute wedge led to prograding shallow water conditions from east to west. These shallow water conditions allowed the Tabon limestone to build up. A rising sea level may have provided additional space for the limestone deposition but the tectonically uplift remained to the main controlling factor for the propagation of the limestones.

The limestones were not affected by the thrusting indicating a deposition after the formation of the accretionary wedge.

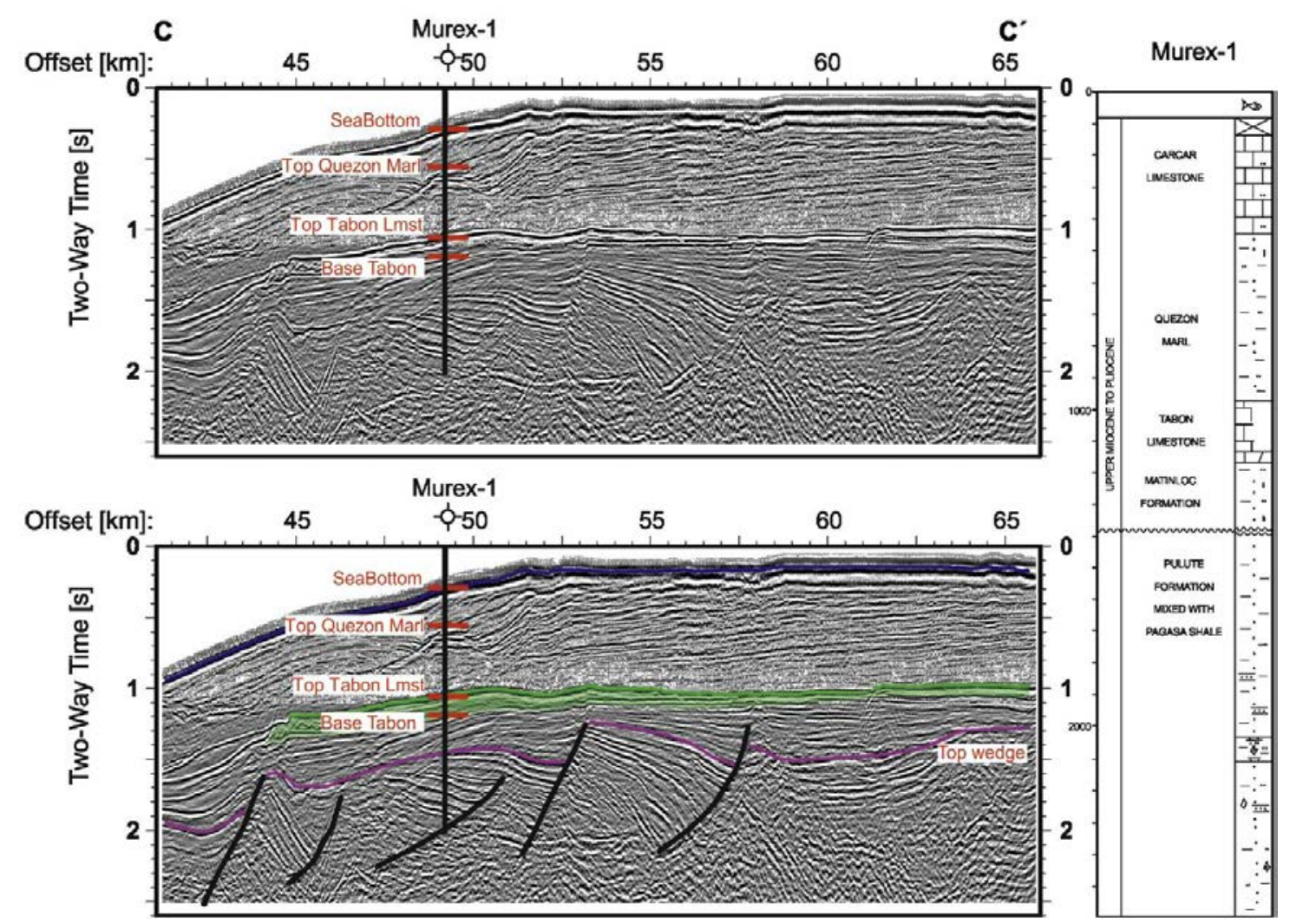

Figure 46: Reflection seismic profile showing the expression of the Tabon limestone. (top - not interpreted; bottom interpreted; right: lithology of Murex-1 well). The position of the Tabon limestone is highlighted in the interpreted section.

\section{Time constraints for the initiation of wedge development}

The timing of the formation of the offshore wedge is constrained by the underlying and overlying carbonate formations. The thrusting postdates the underlying Nido platform carbonates and must have ended before the formation of the overlying Tabon limestone. Even though it is not clear how far the Nido carbonates reach to the east beneath south Palawan their age provides a clear constraint for the initial formation of the thrusted wedge. Biostratigraphic correlation gave an Early Miocene age of 18-20 Ma for the top of these platform carbonates. We conclude that the Pulute wedge was not present before $18 \mathrm{Ma}$. It needed certainly some time allowing the platform carbonates to subside to the present depth but the wedge may have started to form at any time after $18 \mathrm{Ma}$ ago. The Tabon limestone seals the wedge and was therefore deposited after the formation of the wedge. This further 
constrains the development of the wedge in the south Palawan area. Onshore the oldest Tabon limestone is about 16 Ma old (late Early Miocene).

This indicates that the formation of the Pulute wedge started between 18 and 16 Ma ago. From the sealing Tabon limestone it is concluded that the Pulute wedge continued migrating west until the upper Late Miocene ( $7 \mathrm{Ma}$ ). The Tabon limestone continued growing vertically for two more million years before carbonate sedimentation ended at about $5 \mathrm{Ma}$ in the late Late Miocene.

\section{Uplift of southern and central Palawan Island}

If we assume the island of central and south Palawan as a continuation of the thrusted offshore wedge (Hutchison, 2010), which is underpinned by the seismic line BGR8410 running across the wedge between Palawan and Balabac Island, we are able to further constrain the evolution of this island. Central and south Palawan developed during the Miocene with the propagation of the thrusted wedge from the east towards the west. At least the central Palawan area was below sea level before the late Early Miocene. The thrusting and wedge development continued in the offshore area until the early Early Pliocene when the depositional environment on top of the wedge changed from shallow marine to deep marine conditions. This change in the depositional environment coincides with the end of the convergence in the area.

Young uplift of the area around the city of Quezon can be deduced from carbonate precipitates covering a marine bivalve found in a cave. ${ }^{87} \mathrm{Sr} /{ }^{86} \mathrm{Sr}$ dates of these precipitates, provides an age between the Pleistocene (1.2 Ma) and Recent (Rehm, 2002); from which we infer that subaerial conditions prevailed at least since the Pleistocene. An investigation of the lithologies above the Tabon limestone in the wells offshore SW-Palawan shows predominantly claystones and marls in the wells on the southwestern part of this shelf with very minor amounts of silt and very finegrained sandstone further towards the northeast. From this observation we exclude a high input of terrestrial clastics and therefore a nearby landmass. The youngest limestones onshore at the western coast of south Palawan were dated late Middle Miocene (Rehm, 2002).

We suggest therefore that south Palawan and potentially also central Palawan were not exposed before the late Middle Miocene, allowing the reef buildups to develop before their subaerial exposure.

In the seismic lines on the west Palawan shelf an unconformity (named "Base Carcar Limestone", in Figure 44) is distinct. The unconformity was dated as Late Pliocene by Schlüter et al. (1996) and late Late Pliocene (3.4 Ma) in this work. The unconformity is suggested to mark a widespread uplift which is related to a Pliocene tectonic event resulting in folding of the Tabon limestone onshore and probably causing the uplift and subaerial exposure of southern Palawan Island while the Panas/Pulute wedge, in contrast was probably continuously below sea level. The fact that the offshore is not folded may be due to the loss of significance of this tectonic event in western direction. This tectonic event may also be a local feature. 
Having shown show that the Tabon limestone developed from east to west, we believe that the development of these carbonates is tectonically controlled by the uplift associated with the prograding development of the wedge from east to west.
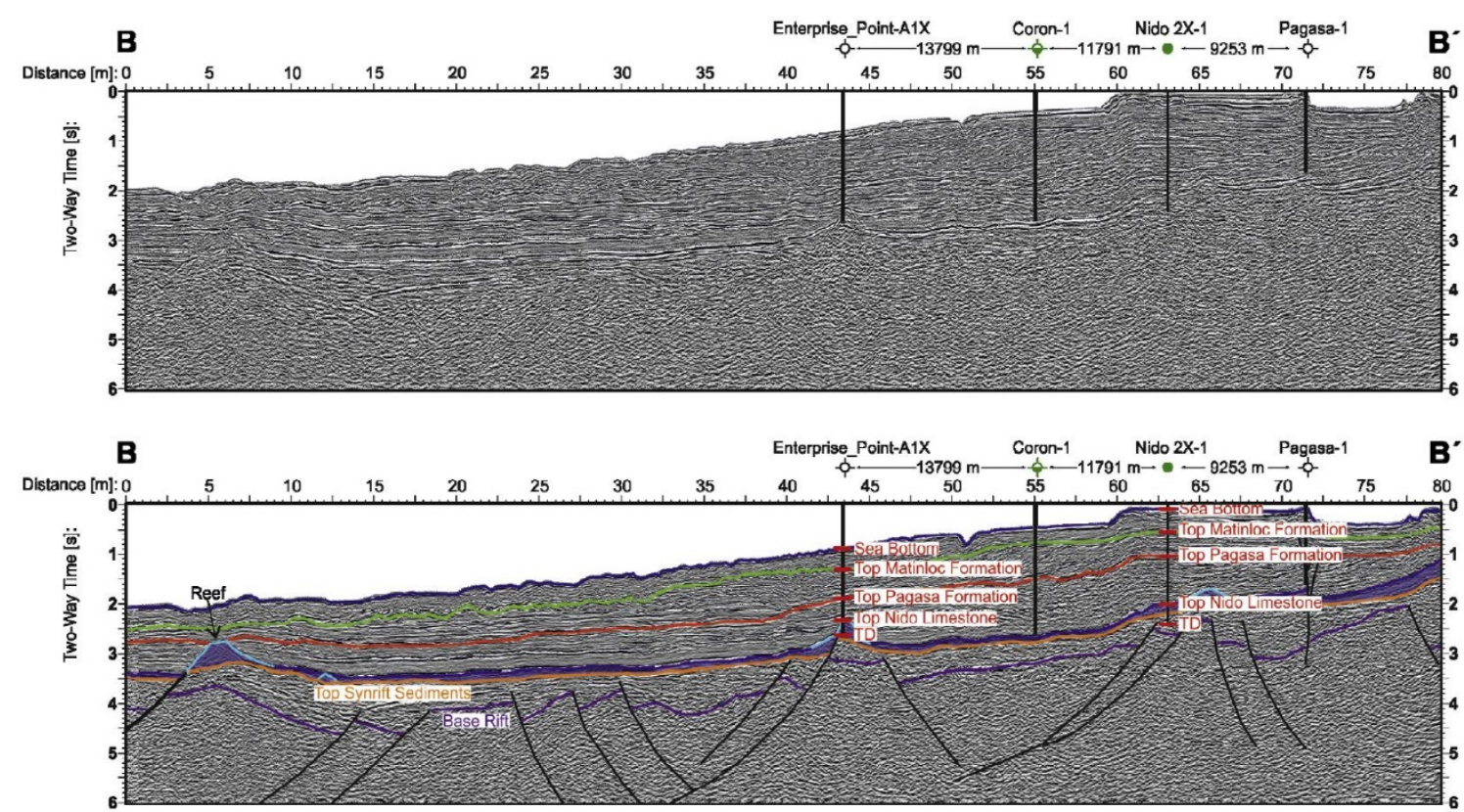

Figure 47: Reflection seismic section across the NW Palawan shelf (top - not interpreted; bottom - interpreted). Position of profile is indicated in Figure 36. The position of the Nido limestone is highlighted by shading. Welltops of two wells are given for correlation. Rift structure and postrift strata are shown. The reef at $\sim 5 \mathrm{~km}$ in an example for isolated carbonate development after the overall cessation of the Nido platform growth.

\section{Uplift of northern Central Palawan}

Further to the north in the Palawan-Borneo Trough the sedimentation within the clastic Matinloc Formation (coeval with the Tabon limestone deposition on the wedge) gets coarser. In front of northern central Palawan two coarse grained (sand- stone/conglomerate) formations with a thickness of about $100 \mathrm{~m}$ were drilled by the Penascosa- 1 well. These two sequences of coarse material may give indications for uplift episodes of the northern part of central Palawan. These two episodes took place at $12 \mathrm{Ma}$, resulting in the deposition of conglomerates and 8-9 Ma, resulting in the deposition of sandstones. In front of NW-Palawan the coarse grained Matinloc Formation was deposited during the Upper Miocene. This indicates a much earlier uplift to subaerial conditions of north Palawan in comparison to central and south Palawan. Onshore northern Palawan this uplift is difficult to confirm since the Oligocene-Early Miocene "St. Pauls/Nido"' limestones are the youngest preserved units (Wolfahrt et al., 1986). It may be speculated that the uplift phase was coeval with the folding of the St. Pauls limestone (equivalent of Nido limestone) however, the timing is poorly constrained. 


\section{Conclusions}

1. The two limestones, Nido and Tabon limestone provide time constraints for the development of the Pulute wedge. The Pulute accretionary wedge did not form in the Palawan area prior to 18 Ma. Thrusting continued to 7 Ma.

2. A detailed age determination and correlation of the Tabon limestone onshore and offshore central and southern Palawan indicates a prograding of these limestones towards the west. This prograding is tectonically controlled by the development of the underlying Pulute wedge.

3. The thrusting of the wedge may be linked to the final collision of the northern (Dangerous Grounds) and southern margin (Cagayan block) of the proto-South China Sea (Rangin et al., 1990). The tectonic uplift of the wedge is related to the outward propagation of the deformation in the thrusted wedge.

4. We show that there is no evidence for the presence of Nido carbonates onshore central and southern Palawan. The limestones cropping out there are merely the younger Tabon limestone.

5. The Nido limestone is distinct underneath the Pulute wedge and could be traced in the seismic lines throughout the Palawan-Borneo Trough until west of Borneo.

6. A second pulse of uplift caused the folding of the Tabon limestone onshore central and southern Palawan. Time constraints for this event are the late Late Pliocene unconformity on the west Palawan shelf and a working spleothem in the Quezon area since 1.2 Ma.

\section{Acknowledgments}

We gratefully acknowledge Total Exploration \& Production GSR/PN/BTF Team for stimulating discussions.

We benefited greatly from constructive reviews from Andrew Cullen, Mike Cottam and an anonymous reviewer which considerably helped to improve the manuscript. Funding of this study by TOTAL E\&P is kindly acknowledged.

\section{Erratum}

A typo survived the reviewing process of this paper. In the chapter "Age for the top of Nido limestone" the position of the well Enterprise Point was given as "1100 km off the coast of North Palawan”. This is not correct. The actual position of this well is $65 \mathrm{~km}$ off the coast of N-Palawan. 


\section{Chapter 5: Discussion}

There were a series of questions raised at the beginning of this thesis. This chapter will summarize what answers could be given to them and how these answers were derived.

\section{How did the southeastern margin of the South China Sea evolve during time?}

As stated before the extrusion theory, relating the opening of the South China Sea with the collision of India and Asia, will not only result in a massive timing problem (the collision was later) but also in geometrical issues. It is very hard to relate a zipper-like opening with strike-slip faults. The best explanation of the zipper-like opening of the SW-subbasin is the slab-pull theory: The subduction of a piece of oceanic crust (Proto South China Sea) towards the southeast. Also the occurrence of Ophiolites onshore southern Palawan indicates the presence of a Proto South China Sea. (Chapter 3 and 4)

After the breakup the southeastern margin of the South China Sea collided with a thrusted wedge to form what is now south Palawan Island (and western Borneo). The load of this wedge caused the rifted continental crust to bend down to form the Palawan-Borneo trough. In this trough early postrift sediments are at a depth of up to $14 \mathrm{~km}$ and the syn-rift sediments are buried even deeper (Chapter 4; Figure 40). Directly west of the trough the crust is slightly bend upward, forming a forebulge. This forebulge enabled the widespread development of carbonates additionally to the tips of tilted fault blocks that provide the shallow water conditions for carbonate development further to the west. (Chapter 3).

The whole system stopped shortly after the collision and some gravitational sliding affected the westernmost parts of the Palawan-Borneo wedge. (Chapter 3). 


\section{Is it possible to find a way of constraining the post-rift development? When did the margin collide and how was this affecting the continental crust?}

In the oceanic part of the South China Sea the spreading history was recently investigated by Barckhausen et al. (2014; 2004) and Ding et al. (2018). In the rifted continental part the development was constrained by using seismic unconformities that could be traced over large areas of the Dangerous Grounds (Chapter 3). Two of these seismic unconformities were assigned to represent the tops of two limestone formations. These limestones were dredged and drilled in several places, allowing the dating of them. Based upon these dating the timing of the collision between the Dangerous Grounds and the Palawan accretionary wedge could be constrained to have happened between 18 and 7 Ma (Chapter 4).

The constraining of this age was a little bit problematic since many of the seismic lines end close to the front of the accretionary wedge and seismic lines shot on the wedge did not resolve the underlying Dangerous Grounds plate. In addition, the wells drilling the Nido limestone are also located close to the wedge front. From some seismic lines it can be inferred that these limestones continue towards the east underneath southern Palawan. Therefore, it is very likely that the collision and wedge initiation started prior to $18 \mathrm{Ma}$, but it is impossible to give an exact age for them.

Assuming the development of a forebulge (Chapter 3) as the main controlling factor for the development of the Nido carbonates it is possible to date the collision back to at least the Late Oligocene.

Another prominent seismic unconformity was used to constrain the post rift development. This unconformity was named "Red unconformity" “C”, “Top Pagasa”, or "Middle Miocene Unconfomity" (Chapter 3). By closely investigating it in the seismic image, it came to view that this unconformity does not represent an erosional event throughout the whole investigation area. Towards the west the erosion at this unconformity gets lesser and it turns into conformity close to the COB offshore North Palawan. Also in the Palawan-Borneo trough it seems that this seismic unconformity does not represent an erosional unconformity (Figure 48).

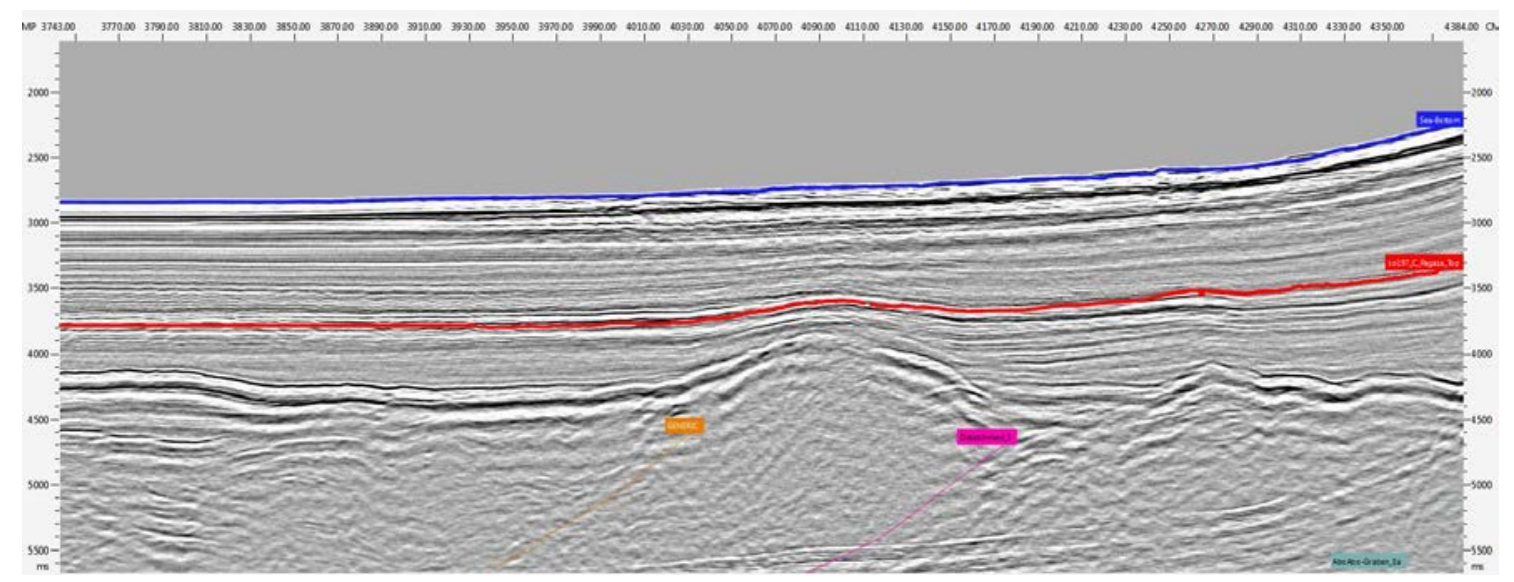

Figure 48: Part of seismic profile so197-30 located in the Palawan-Borneo trough.Red reflector shows no indication of beeing a stratigraphic unconfirmity. 
Offshore North Palawan this unconformity was dated 15.2 Ma (Chapter 4). This unconformity could be traced across the Dangerous Grounds to the Mulu-1 well, here it was dated 11.5 Ma. So this unconformity is also diachronous. The erosional event, associated with the Red unconformity follows the direction of the opening of the SW-subbasin of the South China Sea (Chapter 3).

\section{Is it possible to find the continent-ocean boundary of a proposed proto-South China Sea?}

Unfortunately this is not possible. There are no seismic lines crossing south Palawan Island and most of the seismic lines terminate at the western wedge front about $40 \mathrm{~km}$ off the coast. The only lines crossing the Palawan-Borneo wedge are located between south Palawan and Balabac Island and between Balabac and Borneo. In that area the reflector of the Nido carbonates, which marks the top of the downgoing plate, is located in a depth of about 6 to 7 seconds TWT. The resolution of the seismic lines is not sufficient to resolve any features below a depth of about 2 to 3 seconds TWT underneath the wedge (Figure 49). Illao et al. (2018) could trace the top of the Nido Platform further towards the coastline, but couldn't also find the COT of the Proto South China sea in the 3D seismic they used.

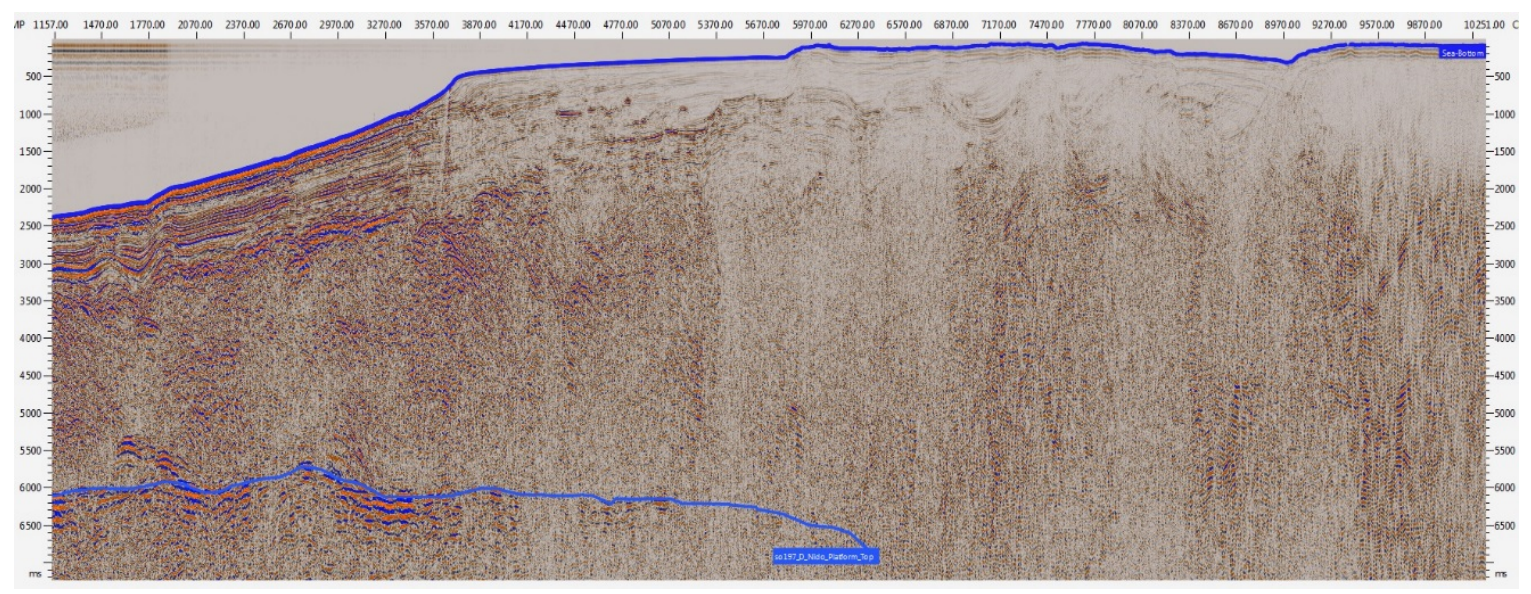

Figure 49: Detail of seismic line BGR84-01, crossing the wedge south of Balabac Island. The reflecion of the Top Nido Platform is hardly visible underneath the western edge of the wedge (left) and underneath the wedge no clear signal could be received below $\sim 3000 \mathrm{~ms}$.

Approaching Palawan Island from the east the seismic lines do also not reach closer to the shoreline than $10 \mathrm{~km}$ and do not resolve any features below the "pink reflector" that is considered to represent the top of the obducted ophiolite. 


\section{How are the carbonates offshore western Palawan distributed? What are the constraints of their development and is it possible to link the development with regional tectonics?}

From the detailed interpretation of seismic lines the distribution of Oligocene to recent carbonates could be deduced (chapter 3). Recent reefs are mainly located on the Reed Bank Block and the tips of tilted fault blocks e.g. the Spratley Islands (Figure 31) and are widespread across the Dangerous Grounds until close to the Palawan Borneo Trough. The Nido Carbonate platform could be traced over large distances within the Palawan Borneo Trough and the easternmost part of the Dangerous Grounds. Here the outline of the platform is lobate and 4 smaller carbonate platforms are located in front of it. Nevertheless these smaller platforms are also seen as Nido Carbonate platform. Further within the Dangerous Grounds no larger continuous carbonate platform could be identified. In the central part of the Dangerous Grounds several reefs seem to have developed along a straight line. This is not a result of geologic development, but results in the fact that only one single seismic profile was available in that area and the reefs could only be interpreted along this profile.

Two other carbonate sequences have developed on top of the accretionary wedge offshore southwest Palawan: The Late Miocene Tabon Limestone and the Quarternary Carcar Limestone. While the Tabon Limestone is restricted to the southwest Palawan shelf, the Carcar Limestone can be found in the shallow water areas all around the island.

The development of the different carbonate formations is controlled by different factors. For the Nido carbonate platform a development on top of a forebulge is inferred by the data. This forebulge developed in response to the loading of the advancing Borneo-Palawan accretionary wedge (chapter 3). Isolated Miocene reefs developed in the shallow water areas on top of the tilted fault blocks in the Dangerous Grounds, some of them prevailed until present.

The advancing accretionary wedge provided also shallow water conditions for the development of carbonates on his top. With the progradation of this wedge the carbonate development also prograded before the carbonates were covered by clastics from Palawan Island (chapter 4).

Finally, the recent carbonates developed in the shallow water areas around Palawan Island. Carbonates on Reed Bank and in some places in the Dangerous Grounds continued their development almost continuously since the Miocene.

There is a clear linkage between the tectonic history and the development of carbonates in the investigation area. The development of the accretionary wedge and the adjacent forebulge control the development of the Nido and Tabon limestone.

Important constraints on the tectonic evolution can also be taken from the carbonates on the Reed Bank block. As pointed out in chapter 3 it can be deduced from the age and the growth rates of the carbonates that after the rifting the Reed Bank block submerged prior to the opening of the SWsubbasin and stayed in shallow water depth for the whole time. From the carbonate deposition can 
be concluded that, unlike in other areas, there is no breakup unconformity on the Reed Bank Block. It may be speculated that the weight of the nearby oceanic crust of the northeastern subbasin held this block down.

Is it possible to correlate the various published and interpreted stratigraphic unconfomities?

In chapter 3 an overview on the different names and relationships of the different unconformities was given. The special focus was set on the prominent unconformity within the Miocene (Red, C, MMU,..). The timing of these unconformities is difficult because all of them are diachronous. The zipperlike opening of the SW-subbasin from the northeast to the southwest caused the breakup unconformity also to get younger towards the southwest. 


\section{Chapter 6: Conclusions}

Within the GRI-project the knowledge of the development of the Dangerous Grounds could be substantially deepened by this investigation (Steuer et al., 2013; Steuer et al., 2014). The Dangerous Grounds started rifting in the Cretaceous. With the onset of the opening of the southwestern oceanic basin at 25 Ma the Dangerous Grounds started moving towards the southeast. Driving force for spreading was the subduction of a Proto-South China Sea in the area east of Palawan. The Kagajan volcanic ridge in the Sulu Sea is seen to be a remnant of it. The seafloor spreading ceased at 20.5 Ma probably due to the blocking of the system by the arrival of the Dangerous Grounds continental plate in the subduction zone. From the southeast the Dangerous Grounds were overthrusted by an accretionary wedge. This convergence continued until 7 to $5 \mathrm{Ma}$, leading to the formation of South Palawan Island.

The development of this accretionary wedge caused a substantial loading of the crust and therefore the development of a foredeep (Palawan-Borneo trench) and a forebulge (Steuer et al., 2014). In the area of the Palawan-Borneo trench the rifted half-grabens of the Dangerous Grounds are submerged in quite high depths. Within the synrift sediments are potential source rocks for hydrocarbons and with the development of the Nido carbonate platform a possible reservoir was deposited prior to the deep submergence. Finally, deepwater clays are deposited shortly after the carbonate sedimentation, building a possible seal over them. 


\section{Chapter 7: Outlook}

During the three years of the project significant new discoveries were made. Still there are a lot of questions left.

How are the Miocene (and younger) reefs distributed over the Dangerous Grounds?

Is it possible to trace the Breakup Unconformity further across the Dangerous Grounds?

The oilfields offshore NW-Palawan (e.g. Malampaia oil field) are located in reefal plays. Why aren't these plays present offshore SW-Palawan, or are they just not found jet?

A similar setting is found within the Dangerous Grounds, is it working / productive?

To address these questions and challenges some more work will be needed:

The amount of seismic lines, especially in the southern part of the Dangerous Grounds should be increased to better constrain the unconformities. With the available lines it was very difficult to trace the Red unconformity from the Mulu-1 well in the south to the wells offshore western Palawan.

Also the number and shape of Miocene reefs within the Dangerous Grounds strongly depends on the number of seismic lines. The linear arrangement of the reefs in Figure 31 is due to the fact that there was only one seismic line available. Additionally, more samples of the Nido carbonate platform on top of the forebulge will be needed to underpin the theory of its westward movement.

Unfortunately, the political situation in the Dangerous Grounds area is quite complex. The region is disputed between the neighboring countries and research is highly hindered by these uncertain territorial claims. 


\section{List of references}

Ali, J.R., Aitchison, J.C., 2008. Gondwana to Asia: Plate tectonics, paleogeography and the biological connectivity of the Indian sub-continent from the Middle Jurassic through latest Eocene (166-35 Ma). Earth-Science Reviews 88, 145-166.

Almasco, J.N., Rodolfo, K., Fuller, M., Frost, G., 2000. Paleomagnetism of Palawan, Philippines. Journal of Asian Earth Sciences 18, 369-389.

Aurelio, M.A.a.P., R.E. Eds., 2010. Geology of the Philippines. 2nd Edition. Mines and Geosciences Bureau, Department of Environment and Natural Resources, Quezon City.

Barckhausen, U., Engels, M., Franke, D., Ladage, S., Pubellier, M., 2014. Evolution of the South China Sea: Revised ages for breakup and seafloor spreading. Marine and Petroleum Geology.

Barckhausen, U., Roeser, H.A., 2004. Seafloor spreading anomalies in the South China Sea revisited, In: Clift, P., Kuhnt, W., Wang, P., Hayes, D.E. (Eds.), Continent-Ocean Interactions in the East Asian Marginal Seas. American Geophysical Union, Geophys. Monograph Series, pp. 121-125.

Berggren, W.A., 1995. A revised Cenozoic geochronology and chronostratigraphy. Geochronology, time scales and global stratigraphic correlation, 129-212\%U http://ci.nii.ac.jp/naid/10004826641/en/.

Bosence, D., 2005. A genetic classification of carbonate platforms based on their basinal and tectonic settings in the Cenozoic. Sedimentary Geology 175, 49-72.

Braitenberg, C., Wienecke, S., Wang, Y., 2006. Basement structures from satellitederived gravity field: South China Sea ridge. Journal of Geophysical Research 111, 1-15.

Briais, A., Patriat, P., Tapponier, P., 1993. Updated interpretation of magnetic anomalies and sea floor spreading stages in the South China Sea: implications for the Tertiary tectonics of Southeast Asia. Journal of Geophysical Research 98, $6299-6328$.

Clift, P., Lee, G.H., Anh Duc, N., Barckhausen, U., Van Long, H., Zhen, S., 2008. Seismic reflection evidence for a Dangerous Grounds miniplate: No extrusion origin for the South China Sea. Tectonics 27, 1-16.

Clift, P., Lee, J.I., Clark, M.K., Blusztajn, J., 2002a. Erosional response of South China to arc rifting and monsoonal strengthening; a record from the South China Sea. Marine Geology 184, 207-226.

Clift, P., Lin, J., Barckhausen, U., 2002b. Evidence of low flexural rigidity and low viscosity lower continental crust during continental break-up in the South China Sea. Marine and Petroleum Geology 19, 951-970.

Clift, P.D., Lin, J., Odp Leg 184 Scientific, P., 2001. Patterns of extension and magmatism along the continent-ocean boundary, South China margin. Geological Society, London, Special Publications 187, 489-510.

Concepcion, R., Dimalanta, C., Yumul, G., Faustino-Eslava, D., Queaño, K., Tamayo, R., Imai, A., 2012. Petrography, geochemistry, and tectonics of a rifted fragment of Mainland Asia: evidence from the Lasala Formation, Mindoro Island, Philippines. International Journal of Earth Sciences 101, 273-290.

Cottam, M., Hall, R., Sperber, C., Armstrong, R., 2010. Pulsed emplacement of the Mount Kinabalu granite, northern Borneo. Journal of the Geological Society of London 167, 49-60.

Cullen, A., 2014. Reprint of: Nature and significance of the West Baram and Tinjar Lines, NW Borneo. Marine and Petroleum Geology 58, 674-686.

Cullen, A., Reemst, P., Henstra, G., Gozzard, S., Ray, A., 2010. Rifting of the South China Sea: new perspectives. Petroleum Geoscience 16, 273-282. 
Cullen, A.B., 2010. Transverse segmentation of the Baram-Balabac Basin, NW Borneo: refining the model of Borneo's tectonic evolution. Petroleum Geoscience 16, 3-29.

Ding, W., Franke, D., Li, J., Steuer, S., 2013. Seismic stratigraphy and tectonic structure from a composite multi-channel seismic profile across the entire Dangerous Grounds, South China Sea. Tectonophysics 582, 162-176.

Ding, W., Sun, Z., Dadd, K., Fang, Y., Li, J., 2018. Structures within the oceanic crust of the central South China Sea basin and their implications for oceanic accretionary processes. Earth and Planetary Science Letters 488, 115-125.

Ding, W.W., Li, J.B., 2011. Seismic stratigraphy, tectonic structure and extension factors across the southern mar; Of the South China Sea: Evidence from two regional multi-channel seismic profiles. Chinese Journal of Geophysics (Acta Geophysica Sinica) 54, 3038-3056.

Edwards, P.B., 1992. Structural evolution of the Western Pearl River Mouth Basin, In: Watkins, J.S., Feng, Z., McMillen, K.J. (Eds.), Geology and Geophysics of Continental Margins. Am. Assoc. Pet. Geol. Memoir, pp. 43-52.

Encarnacion, J., 2004. Multiple ophiolite generation preserved in the northern Philippines and the growth of an island arc complex. Tectonophysics 392, 103130.

Feng, Z., Miao, W., Zheng, W., Chen, S., 1992. Structure and hydrocarbon potential of the para-passive continental margin of the northern South China Sea, In: Watkins, J.S., Feng, Z., McMillen, K.J. (Eds.), Geology and Geophysics of Continental Margins. Am. Assoc. Pet. Geol. Mem., pp. 27-41.

Fournier, F., Borgomano, J., Montaggioni, L.F., 2005. Development patterns and controlling factors of Tertiary carbonate buildups: Insights from high-resolution 3D seismic and well data in the Malampaya gas field (Offshore Palawan, Philippines). Sedimentary Geology 175, 189-215.

Franke, D., 2013. Rifting, lithosphere breakup and volcanism; comparison of magmapoor and volcanic rifted margins. Marine and Petroleum Geology 43, 63-87.

Franke, D., Barckhausen, U., Baristeas, N., Engels, M., Ladage, S., Lutz, R., Montano, J., Pellejera, N., Ramos, E.G., Schnabel, M., 2011. The continent-ocean transition at the southeastern margin of the South China Sea. Marine and Petroleum Geology 28, 1187-1204.

Franke, D., Barckhausen, U., Heyde, I., Tingay, M., Ramli, N., 2008. Seismic images of a collision zone offshore NW Sabah/Borneo. Marine and Petroleum Geology 25, 606-624.

Franke, D., Savva, D., Pubellier, M., Steuer, S., Mouly, B., Auxietre, J.L., Meresse, F., Chamot-Rooke, N., 2014. The final rifting evolution in the South China Sea. Marine and Petroleum Geology 58, 704-720.

Fyhn, M.B.W., Boldreel, L.O., Nielsen, L.H., 2009. Geological development of the Central and South Vietnamese margin: Implications for the establishment of the South China Sea, Indochinese escape tectonics and Cenozoic volcanism. Tectonophysics 478, 184-214.

Grötsch, J., Mercadier, C., 1999. Integrated 3-D Reservoir Modeling Based on 3-D Seismic: The Tertiary Malampaya and Camago Buildups, Offshore Palawan, Philippines. AAPG Bulletin 83, 1703-1728.

Hall, R., 2002. Cenozoic geological and plate tectonic evolution of SE Asia and the SW Pacific: computer-based reconstructions, model and animations. Journal of Asian Earth Sciences 20, 353-431.

Hall, R., Breitfeld, H.T., 2017. Nature and demise of the Proto-South China Sea. Bulletin of the Geological Society of Malaysia 63, 61-76.

Hall, R., Morley, C.K., 2004. Sundaland Basins, Continent-Ocean Interactions Within East Asian Marginal Seas. American Geophysical Union, Geophyscial Monograph Series, pp. 55-85. 
Hall, R., Nichols, G., 2002. Cenozoic sedimentation and tectonics in Borneo; climatic influences on orogenesis. Geological Society Special Publications 191, 5-22.

Hall, R., van Hattum, M.W.A., Spakman, W., 2008. Impact of India-Asia collision on SE Asia: The record in Borneo. Tectonophysics 451, 366-389.

Haq, B.U., Hardenbol, J.A.N., Vail, P.R., 1987. Chronology of Fluctuating Sea Levels Since the Triassic. Science 235, 1156-1167.

Hesse, S., Back, S., Franke, D., 2009. The deep-water fold-and-thrust belt offshore NW Borneo: Gravity-driven versus basement-driven shortening. Geological Society of America Bulletin 121, 939-953.

Hesse, S., Back, S., Franke, D., 2010a. Deepwater folding and thrusting offshore NW Borneo, SE Asia. Geological Society, London, Special Publications 348, 169-185.

Hesse, S., Back, S., Franke, D., 2010b. The structural evolution of folds in a deepwater fold and thrust belt; a case study from the Sabah continental margin offshore NW Borneo, SE Asia. Marine and Petroleum Geology 27, 442-454.

Hesse, S., Back, S., Franke, D., 2010c. The structural evolution of folds in a deepwater fold and thrust belt - a case study from the Sabah continental margin offshore NW Borneo, SE Asia. Marine and Petroleum Geology In Press, Corrected Proof.

Hinz, K., Fritsch, J., Kempter, E.H.K., Manaaf Mohammad, A., Meyer, H., Mohamed, D., Vosberg, H., Weber, J., Benavides, J.J., 1989. Thrust Tectonics along the continental margin of Sabah, Northwest Borneo. Geologische Rundschau 78, 705-730.

Hinz, K., Schlüter, H.U., 1985. Geology of the dangerous grounds, South China Sea, and the continental margin of southwest Palawan: Results of Sonne cruises SO23 and SO-27. Energy 10, 297-315.

Holloway, N.H., 1982. North Palawan Block, Philippines - Its relation to Asian Mainland and Role in Evolution of South China Sea. AAPG Bulletin 66, 1355-1383.

Hsu, S.-K., Yeh, Y.-c., Doo, W.-B., Tsai, C.-H., 2004. New Bathymetry and Magnetic Lineations Identifications in the Northernmost South China Sea and their Tectonic Implications. Marine Geophysical Researches 25, 29-44.

Hutchison, C.S., 1996. The 'Rajang accretionary prism' and 'Lupar Line' problem of Borneo. Geological Society Special Publications 106, 247-261.

Hutchison, C.S., 2004. Marginal basin evolution: the southern South China Sea. Marine and Petroleum Geology 21, 1129-1148.

Hutchison, C.S., 2005a. Chapter XIV - The Ophiolitic Basement, Geology of NorthWest Borneo. Elsevier, Amsterdam, pp. 195-223.

Hutchison, C.S., 2005b. Regional Tectonic Setting, Geology of North-West Borneo. Elsevier, Amsterdam, pp. 5-7.

Hutchison, C.S., 2010. The North-West Borneo Trough. Marine Geology 271, 32-43.

Hutchison, C.S., Vijayan, V.R., 2010. What are the Spratly Islands? Journal of Asian Earth Sciences 39, 371-385.

Ilao, K.A., Morley, C.K., Aurelio, M.A., 2018. 3D seismic investigation of the structural and stratigraphic characteristics of the Pagasa Wedge, Southwest Palawan Basin, Philippines, and their tectonic implications. Journal of Asian Earth Sciences 154, 213-237.

Ingram, G.M., Chisholm, T.J., Grant, C.J., Hedlund, C.A., Stuart-Smith, P., Teasdale, J., 2004. Deepwater North West Borneo: hydrocarbon accumulation in an active fold and thrust belt. Marine and Petroleum Geology 21, 879-887.

Ishihara, T., Kisimaoto, K., 1996. Magnetic anomaly map of East Asia 1:4.000.000 [CD-ROM]. Geological Survey of Japan and Coordinating Committee for Costal and Offshore Geoscience Programs in East and Southeast Asia (CCOP).

King, R.C., Backé, G., Morley, C.K., Hillis, R.R., Tingay, M.R.P., 2010. Balancing deformation in NW Borneo: Quantifying plate-scale vs. gravitational tectonics in a delta and deepwater fold-thrust belt system. Marine and Petroleum Geology 27, 238-246. 
Kudrass, H.R., Müller, P., Kreuzer, H., Weiss, W., 1990. Volcanic rocks and Tertiary carbonates dredged from the Cagayan Ridge, In: Rangin, C., Silver, E., von Breymann, M.T., al., e. (Eds.), Proceedings of the Ocean Drilling Program, Initial Reports, pp. 93-100.

Kudrass, H.R., Wiedicke, M., Cepek, P., Kreuzer, H., Müller, P., 1986. Mesozoic and Cainozoic rocks dredged from the South China Sea (Reed Bank area) and Sulu Sea and their significance for plate-tectonic reconstructions. Marine and Petroleum Geology 3, 19-30.

Letouzey, J., Sage, L., Müller, C., 1988. Geological and structural maps of Eastern Asia, Introductory notes. AAPG, Tulsa, OK.

Levell, B.K., 1987. The nature and significance of regional unconformities in the hydrocarbon-bearing Neogene sequence offshore West Sabah. Buletin Persatuan Geologi Malaysia = Bulletin Geological Society of Malaysia 21, 55-90.

Lin, A.T., Watts, A.B., Hesselbo, S.P., 2003. Cenozoic stratigraphy and subsidence history of the South China Sea margin in the Taiwan region. Basin Research 15, 453-478.

Lin, C., Jiang, J., Shi, H., Zhang, Z., Liu, J., Qin, C., Li, H., Ran, H., Wei, A., Tian, H., Xing, Z., Yao, Q., 2018. Sequence architecture and depositional evolution of the northern continental slope of the South China Sea: responses to tectonic processes and changes in sea level. Basin Research 30, 568-595.

Liu, H.-I., Yan, P., Zhang, B.-y., Sun, Y., Zhang, Y.-X., Shu, L.-S., Qiu, X.-I., Guo, L.-Z., 2004. Role of the Wan-Na fault system in the western Nansha Islands (Southern South China Sea). Journal of Asian Earth Sciences 23, 221-233.

Lüdmann, T., Wong, H.K., 1999. Neotectonic regime on the passive continental margin of the northern South China Sea. Tectonophysics 311, 113-138.

Ma, Y., Wu, S., Lv, F., Dong, D., Sun, Q., Lu, Y., Gu, M., 2011. Seismic characteristics and development of the Xisha carbonate platforms, northern margin of the South China Sea. Journal of Asian Earth Sciences 40, 770-783.

Madon, M., Kim, C.L., Wong, R., 2013. The structure and stratigraphy of deepwater Sarawak, Malaysia: Implications for tectonic evolution. Journal of Asian Earth Sciences.

Mansor, M.Y., Snedden, J.W., Sarg, J.F., Smith, B.S., Kolich, T., Carter, M., 1999. Pre-drill predictions versus post-drill results: use of sequence stratigraphic methods in reduction of exploration risk, Sarawak Deep-water Blocks, Malaysia. Journal of Asian Earth Sciences 17, 247-254.

McCabe, R., Almasco, J.N., 1983. Terranes of the central Philippines. Stanford University Publications. Geological Sciences 18, 142-142.

Milsom, J., Holt, R., Bin Ayub, D., Smail, R., 1997. Gravity anomalies and deep structural controls at the Sabah-Palawan margin, South China Sea., In: Frazer, A.J., Matthews, S.J., Murphy, R.W. (Eds.), Petroleum Geology of Southeast Asia. Geol. Soc. Spec. Pub., London, pp. 417-427.

Moores, E.M., Twiss, R.J., 1995. Tectonics. W.H. Freeman and Company : New York, NY, United States, United States.

Morley, C.K., 2002. A tectonic model for the Tertiary evolution of strike-slip faults and rift basins in SE Asia. Tectonophysics 347, 189- 215.

Morley, C.K., Back, S., 2008. Estimating hinterland exhumation from late orogenic basin volume, NW Borneo. Journal of the Geological Society of London 165, 353366.

Morley, C.K., Back, S., Van Rensbergen, P., Crevello, P., Lambiase, J.J., 2003. Characteristics of repeated, detached, Miocene-Pliocene tectonic inversion events, in a large delta province on an active margin, Brunei Darussalam, Borneo. Journal of Structural Geology 25, 1147-1169. 
Müller, C., 1991. Biostratigraphy and Geological Evolution of the Sulu Sea and Surrounding Area, In: E.A. Silver, Rangin, C., Breymann, M.T.v. (Eds.), Proceedings of the Ocean Drilling Program, Scientific Results, Vol. 124. ODP, College Station, TX, pp. 121-130.

Nanda, N.C., 2016. Seismic data interpretation and evaluation for hydrocarbon exploration and production: A practitioner's guide. Springer International Publishing, Great Britain.

Pubellier, M., Ali, J., Monnier, C., 2003. Cenozoic Plate interaction of the Australia and Philippine Sea Plates: "hit-and-run" tectonics. Tectonophysics 363, 181-199.

Pubellier, M., Savva, D. Aurelio, M., Sapin, F., 2016. Structural map of the South China Sea. Commission for the Geological Map of the World.

Qianyu Li, Z.J., Baohua Li, 2004. Oligocene-Miocene Planctonic Foraminifer Biostratigraphy, Site 1148, Northern South China Sea. Proceedings of the Ocean Drilling Program, Scientific Results 184.

Rammlmair, D., Raschka, H., Steiner, L., 1987. Geology and Chromatite Mineralization of the Central Palawan Ophiolite, Philippines. BGR, p. 140.

Rangin, C., 1991. Neogene arc-continent collision in Sabah, Northern Borneo (Malaysia)--Reply. Tectonophysics 200, 330-332.

Rangin, C., Bellon, H., Benard, F., Letouzey, J., Muller, C., Sanudin, T., 1990. Neogene arc-continent collision in Sabah, Northern Borneo (Malaysia). Tectonophysics 183, 305-319.

Rehm, S., 2002. The Miocene Carbonates in Time and Space On- and Offshore SW Palawan, Philippines, Mathematisch-Naturwissenschaftliche Fakultät. ChristianAlbrechts-University, Kiel.

Replumaz, A., Tapponier, P., 2003. Reconstruction of the deformed collision zone between India and Asia by backward motion of lithospheric blocks. Journal of Geophysical Research 108.

Ru, K., Di, Z., Chen, H.-Z., 1994. Basin evolution and hydrocarbon potential of the northern South China Margin, In: Di, Z.e.a. (Ed.), Oceanology of China Seas, pp. 361-372.

Ru, K., Pigott, J.D., 1986. Episodic rifting and subsidence in the South China Sea. AAPG Bulletin 70, 1136-1155.

Sapin, F., Pubellier, M., Lahfid, A., Janots, D., Aubourg, C., Ringenbach, J.-C., 2011. Onshore record of the subduction of a crustal salient: example of the NW Borneo Wedge. Terra Nova, no-no.

Savva, D., Meresse, F., Pubellier, M., Chamot-Rooke, N., Lavier, L., Po, K.W., Franke, D., Steuer, S., Sapin, F., Auxietre, J.L., Lamy, G., 2013. Seismic evidence of hyper-stretched crust and mantle exhumation offshore Vietnam. Tectonophysics $608,72-83$.

Schlager, W., 1981. The paradox of drowned reefs and carbonate platforms. Geological Society of America Bulletin 92, 197-211.

Schlüter, H.U., Hinz, K., Block, M., 1996. Tectono-stratigraphic terranes and detachment faulting of the South China Sea and Sulu Sea. Marine Geology 130, 39-51.

Shao, L., Cao, L., Qiao, P., Zhang, X., Li, Q., van Hinsbergen, D.J.J., 2017. Cretaceous-Eocene provenance connections between the Palawan Continental Terrane and the northern South China Sea margin. Earth and Planetary Science Letters 477, 97-107.

Shipboard Scientific Party, 2000. Leg 184 Summary: Exploring the Asian Monsoon through Drilling in the South China Sea, In: Wang, P., Prell, W., Blum, P. (Eds.), Proc. ODP, Initial Results. IODP, College Station, TX, pp. 1-77. 
Steuer, S., Franke, D., Meresse, F., Savva, D., Pubellier, M., Auxietre, J.-L., Aurelio, M., 2013. Time constraints on the evolution of southern Palawan Island, Philippines from onshore and offshore correlation of Miocene limestones. Journal of Asian Earth Sciences 76, 412-427.

Steuer, S., Franke, D., Meresse, F., Savva, D., Pubellier, M., Auxietre, J.L., 2014. Oligocene-Miocene carbonates and their role for constraining the rifting and collision history of the Dangerous Grounds, South China Sea. Marine and Petroleum Geology.

Suzuki, S., Shizuo, T., Graciano, P.Y., Sevillo, D.D., Daniel, K.A., 2000. Composition and provenance of the Upper Cretaceous to Eocene sandstones in Central Palawan, Philippines: Constraints on the tectonic development of Palawan. The Island Arc 9, 611-626.

Taylor, B., Hayes, D.E., 1980. The tectonic evolution of the South China Basin, In: Hayes, D.E. (Ed.), The Tectonic and Geologic Evolution of Southeast Asian Seas and Islands, Part 1. Am. Geophys. Union Geophys. Monogr., pp. 89-104.

Taylor, B., Hayes, D.E., 1983. Origin and history of the South China Sea Basin, In: Hayes, D.E. (Ed.), The Tectonic and Geologic Evolution of Southeast Asian Seas and Islands. AGU, Washington, DC, pp. 23-56.

Thies, K.J., Tearpock, D.J., Bischke, R.E., Boyer, J., Mansor, A., Hamdan, M., 2005. The structure and sequence stratigraphy of extensional basins; a case study offshore Sarawak and Sabah. Abstracts: Annual Meeting - American Association of Petroleum Geologists 14, A138-A138.

Tongkul, F., 1991. Tectonic evolution of Sabah, Malaysia. Journal of Southeast Asian Earth Sciences 6, 395-405.

Williams, H.H., 1997. Play concepts-northwest Palawan, Philippines. Journal of Asian Earth Sciences 15, 251-273.

Wolfahrt, R., Cepek, P., Gramann, F., Kempter, E., Porth, H., 1986. Stratigraphy of Palawan Island. Newsletter Stratigraphy 16, 19-48.

$\mathrm{Wu}$, J., 1994. Evaluation and models of cenozoic sedimentation in the South China Sea. Tectonophysics 235, 77-98.

Yeh, Y.-C., Sibuet, J.-C., Hsu, S.-K., Liu, C.-S., 2010. Tectonic evolution of the Northeastern South China Sea from seismic interpretation. J. Geophys. Res. 115, B06103.

Zamoras, L.R., Matsuoka, A., 2004. Accretion and postaccretion tectonics of the Calamian Islands, North Palawan block, Philippines. The Island Arc 13, 506-519.

Zhou, D., Ru, K., Chen, H.-z., 1995. Kinematics of Cenozoic extension on the South China Sea continental margin and its implications for the tectonic evolution of the region. Tectonophysics 251, 161-177.

Zhou, H., Xiao, L., Dong, Y., Wang, C., Wang, F., Ni, P., 2009. Geochemical and geochronological study of the Sanshui basin bimodal volcanic rock suite, China: Implications for basin dynamics in southeastern China. Journal of Asian Earth Sciences 34 178-189.

Zhou, X.M., Li, W.X., 2000. Origin of Late Mesozoic igneous rocks in Southeastern China: implications for lithosphere subduction and underplating of mafic magmas. Tectonophysics 326, 269-287. 


\section{List of figures}

Figure 1: Satellite image of the South China Sea. The approximate outline of the investigation area is marked by a red rectangle. The thin yellow dotted line represents the approximate outline of the oceanic part of the South China Sea while the dashed white line marks the approximate position of the old mid oceanic ridge.

Figure 2: Detail of the Structural Map of the South China Sea redrawn after Pubellier et al. (2016). Areas outside the main area of interest are shaded. The whole map showing the island of Palawan (coastline of the main island highlighted) in the right and the Dangerous Grounds in the central part. The oceanic basin of the South China Sea is visible in the upper part of the map and the Island of Borneo in the lower central part.

Figure 3: Overview map of the investigation area. The area of interest comprises the

Reed Bank, Spratley islands, the Dangerous Grounds and the Palawan - Borneo trough. In the offshore areas the $1000 \mathrm{~m}$ depth contours are shown.

Figure 4: Seismic time section showing a halfgraben in the Dangerous Grounds. At least three rifting episodes (divided by the green and light blue horizons) are visible within the halfgraben. The main tectonic activity is sealed by the Breakup unconformity (orange)

Figure 5: Detail of a seismic line showin the thrusted wedge offshore SW-Palawan. The interpretation of the tops of the two correlative carbonate formations are shown. Top of Tabon Limestone in Purple and top of Nido Limestone in Blue. The thrusted wedge is located between these formations.

Figure 6: Geodynamic setting in SE-Asia, showing age boundaries and offsets on large strike-slip faults. Minimum offsets (in km) and oldest ages of offsets (in Ma) are given. Bold arrows on strike-slip faults represent sense of largest Tertiary movement, small arrows show Quaternary movement. The approximate location of the working area is marked by a red rectangle. Redrawn after Briais et al. (1989).

Figure 7: Reconstruction of the opening of the South China Sea. Redrawn after Briais et al.( 1993)

Figure 8: Reconstruction of the tectonic history of Asia by Hall (2002). Examples are given for 5 My intervals between 35 Ma and 10 Ma. The existence of a Proto-South China Sea is assumed 
Figure 9: Schematic drawing of the slab-rollback underneath eastern China indicating the movement of the magmatic active zone towards the subduction zone. The transect is located in the northeastern SCS area near Taiwan. Redrawn after Zhou and $\operatorname{Li}(2000)$

Figure 10: Sketches illustrating the early evolution of the South China Sea rift (not to scale). (A) In the rifting stage brittle deformation in the upper crust results in basin formation while ductile extension in the middle crust is compensated by doming in the Moho. Lacustrine / deltaic sedimentation prevails. (B) Extension localizes in the rift basins. The faults are becoming shallower and detachment faulting initiates. Continuing extension in the middle crust is compensated by further Moho uplifts beneath the rift basins. Lacustrine / deltaic sedimentation continues. (C) Crustal thinning approaches the point where the entire crust becomes brittle and crustalscale faults at the rim of crustal blocks cut through the entire crust. Sedimentation is shallow marine. (D) Mantle exhumation along a detachment fault that develops from the previous crustal-scale fault at the rim of crustal blocks. When the asthenospheric mantle reaches the surface accretion of oceanic crust and post-rift volcanism takes place. (Franke et al., 2014).....

Figure 11: Bathymetric map of the SCS with magnetic profiles shown as wiggles along shiptracks and magnetic anomaly interpretation (yellow). Heavy lines are abandoned spreading ridges, numbers indicate magnetic crons. Figure from Barckhausen et al. 2014

Figure 12: Geologic map of Palawan Island. Offshore wells are indicated. Picture from (Steuer et al., 2013)(Chapter 4).

Figure 13: Schematic drawing of the opening history of the SCS. Redrawn after Savva (2013); Holloway (1982) and Kudrass (1990). Drawing not to scale.

Figure 14: Overview of used seismic lines in the Dangerous Ground: Seismic lines shot by BGR are colored red

Figure 15: Seismostratigraphic concepts for the southeastern part of the South China Sea

Figure 16: Map of the interpreted main fault system offshore SW Palawan. Coastline, wells and depth contours are shown for orientation 
Figure 17: Ulugan Fault Zone. Top left: Satellite image (Google Earth) of Central Palawan and Ulugan Bay with the inferred position of the fault (dotted line). Top right: Satellite image (Google Earth) of Ulugan Bay. Two side-branches of the fault could be deduced from the position of an island within the bay and the dipping of rocks on it. Bottom left: Almost vertical fault plane of Ulugan fault at Ulugan Bay (location see top left image). Bottom right: schematic drawing (not to scale) of Ulugan Fault Zone. The normal faults will most likely feature a strong strike-slip component.

Figure 18: Overview map showing the locations of wells and dredge sites used in this investigartion.

Figure 19: Re-drawn well-log of Paz-1 with biostratigraphic markers from Robertson

Research (colored). Ages for zonetops are given on the right...........................................30

Figure 20: Well correlation across the SW-Palawan shelf ........................................................31

Figure 21: Gridded depth to the seafloor in seconds (TWT). Bathymetry by GEBCO shown by the blue isolines. Seismic lines are also shown................................................33

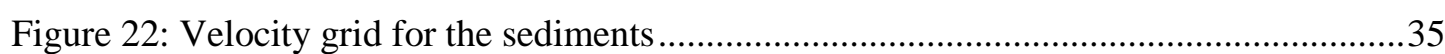

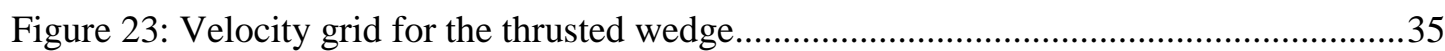

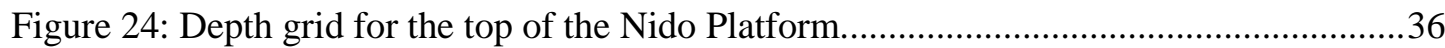

Figure 25: The southeastern South China Sea with depth contours indicated in $1000 \mathrm{~m}$ spacing. The continent -ocean transition is approximately located at the $3000 \mathrm{~m}$ contour. Positions of the seismic reflection lines, wells and dredge sites are shown. The data set comprises about 30,000 km of 2D multichannel seismic lines, 110 wells and 30 dredge sites. Seismic lines, presented in this article, are marked by a bold line. The symbols of wells mentioned in other figures are shown enlarged.

Figure 26: Generalized seismostratigraphy for the Dangerous Grounds summarized from Steuer, Franke, Vihajan, Cullen, etc... The main formations are divided into the western part and the eastern part close to the Palawan-Borneo wedge. The main unconformities (Breakup and "Red" unconformity) are time- and spacetransgressive over the investigation area. Breakup of the Southwestern Subbasin of the South China Sea initiated first in the north and propagated toward the southwest. The Breakup unconformity follows this direction. The Top Nido unconformity is a seismic horizon caused by the velocity increase at the top of a carbonate succession. 
Figure 27: Seismic profile across the southern Dangerous Grounds, running from northwest (up-left) to southeast (low-right). The depth is given in two-way-time and the horizontal distance in kilometers. The profile is divided into two parts for better visibility. Distinct features from left to right are draped reefs in the Dangerous Grounds, the stronger uplifted forebulge, the Palawan-Borneo trough and the western end of the Palawan-Borneo wedge. This wedge is located on top of the downgoing rifted continental crust of the Dangerous Grounds. Reefs are marked with light blue color, also the "Red" unconformity was emphasized. Reefs that were covered by sediments prior to the "Red" unconformity are located e.g. at km 14 or at km 178. Reefs with an onlapping "Red” unconformity are located e.g. at km 194. A reef with almost no sedimentary cover is located at $\mathrm{km} \mathrm{214}$, but it is at a water depth that inhibits further reef development

Figure 28: Two schematic crustal-scale profiles across the Dangerous Grounds in NWSE direction. The location of the lines is given in fFigure 25. The depth of the Moho is modeled from refraction and gravity data and extrapolated in the eastern (right) part of profile B. The limit of available refraction data is indicated by a white vertical line. Both profiles show the rifted continental crust of the Dangerous Grounds. The "Red" unconformity, sealing the tectonics in the western (left) part is indicated. Also the Oligocene-Miocene carbonates are highlighted. The position of the foredeep and forebulge is shown. It is noticeable that the Sabah Basin in NW Borneo formed over the most attenuated part of the continental crust.

Figure 29: Seismic image of the carbonate platform and a Miocene reef on top at the location of the Cadlao-1 well. The vertical scale is given in two-way-time. The most distinct reflection is the positive reflector on top of the carbonates. The "Red" unconformity is represented by a weak reflector, indicating that at this point it rather represents the top of a clastic succession than an erosional unconformity. The interpreted horizons are matched to the drilled stratigraphy of the well Cadlao-1 given at the right side.

Figure 30: Image of a 2D multichannel seismic line in NW-SE-direction across the Borneo-Palawan trough at the well Aboabo A-1X, offshore southern Palawan. The vertical scale is given in two-way-time, the horizontal scale is in kilometer. The base of the carbonate platform is sealing most of the extensional tectonics before it was overthrusted by the Palawan-Borneo wedge (right). The "Red" unconformity is located well above the carbonate platform. So it is a post-rift-feature in the trough. Parts of the strata underneath this unconformity are incorporated in the wedge. 
Figure 31: The distribution of the Oligocene-Miocene carbonate platform and the position of reefs in the Dangerous Grounds. Areas where the existence of the carbonate platform is less clear are shaded in lighter gray. Reefs were categorized according to the end of their development and marked with different colors. Reefs taken from literature (Letouzey et al., 1988) or with unknown age for the end of development are also given in this map. An elongated cluster of "post red drowned reefs" is located at the western edge of the carbonate platform, the development of these reefs probably is related to the development of the Palawan-Borneo trough

Figure 32: Seismic images of reefs ending their development at different times. The reference horizon for timing the development is the "Red" unconformity (RU). The reefs could be clearly identified by their specific shape in the seismic image. A: Early Miocene reefs are covered by Early Miocene strata and therefore ended their development prior to the formation of the RU; B,C: Post-“Red”/drowned reefs continued to develop during the Early Miocene and are not affected by the RU. They are draped by Middle Miocene or younger sediments. This sedimentary cover occasionally is very thin ( 0.2 s TWT) as shown in C; D: Top "Red" reefs are cut at their top by the RU indicating uplift above sea level in the Early Miocene.

Figure 33: Paleo-landscape of the Dangerous Grounds in the Early Miocene as inferred from the position of reefs and unconformities as shown in fFigure 31. For orientation the present coastline is shown as thin, continuous line. The area is divided into three parts. The oceanic domain is almost completely submerged and covered by deep water. The Palawan-Borneo trough acts as trap for sediments provided by a landmass in the southeast, the main directions of sedimentation are indicated by arrows. Due to this sediment trap only a minor amount of clastic sediments was deposited in the central Dangerous Grounds. The forebulge provided shallow water conditions favorable for reef development. Partly this forebulge was above sea level and most of the islands in Early Miocene times are located on it. There was probably another landmass southwest of the forebulge, due to our limitation of seismic lines in this area its outline is speculative.

Figure 34: 2D seismic line across the Reed Bank block at well Sampaguita-1. On the Reed Bank block the carbonates also seal the extensional tectonics. In contrast to the Dangerous Grounds the carbonate deposition on the Reed Bank initiated in the Early Oligocene ( $\sim 30 \mathrm{Ma}$ ) and continued until present as it is also indicated in the lithology of the well at the right side of the figure. 
Figure 35: Schematic development of the carbonate platform on top of a forebulge. This section is running in NW-SE direction in the southern part of the Dangerous Grounds. In the Oligocene the carbonate development initiated on the highest crests of tilted fault blocks. With the uplift of the forebulge, caused by the arrival of the wedge (right) the shallow water conditions with active carbonate development migrated toward the northwest while in the southeast the carbonates drowned. A red rectangle is indicating the NW migrating zone of active carbonate deposition. In the Early Miocene parts of the carbonates were exposed, on the wedge the Deep Regional Unconformity (DRU) forms. In the Late Miocene the convergence had stopped. The frontal part of the wedge is deformed by gravitational tectonics and the Dangerous Grounds undergo subsidence. In many places reefs were able to keep up and to further develop until present.

Figure 36: Regional map showing the locality of Palawan Island and main tectonic features, as well as the location of wells offshore Palawan. Wells which are referred to in the text are enlarged and the names are shown in the map. Solid black lines indicate the locations of the three seismic lines shown in figures XXX. The extend of the offshore accretionary wedge is indicated. The bathymetric data is taken from the General Bathymetric Chart of the Oceans (GEBCO)

Figure 37: Generalized stratigraphic columns of the western Palawan shelf. Separate columns are given for the northern and southern part of the shelf. The ages for the boundaries between the epochs are taken from the International Stratigraphic Chart by the International Commission on Stratigrapy ICS, 2012 (www.Stratigraphy.org). Ages given on the right side next to the unconformities were derived from a biostratigraphic correlation. The main interpreted unconformities are highlighted and assigned the colors shown in the seismic sections. In addition the main tectonic events are also plotted to the columns.

Figure 38: Geological map of Palawan Island adapted and modified from the JICAMMAJ data and maps (1989). Offshore wells are indicated. The legend shows the main geological units of northern and central-south Palawan.

Figure 39: Correlation chart of ten selected wells offshore west Palawan. Superimposed on the lithologs of the wells the tops of planktonic foraminifera zones are shown. The assigned ages for these formation tops are given in the legend. The three main formations (Tabon limestone, Nido limestone and the thrusted wedge) are highlighted by shaded background. The location of the wells is given on the small inset maps and on Figure 36 and Figure 38. The inferred position of the Ulugan Fault Zone is drawn as a dotted black line 
Figure 40: Depth of the Top Nido platform carbonates. Thick solid lines indicate the coastline and $100 \mathrm{~m}$ depth contours are shown as dashed lines. The inferred position of the Ulugan Fault Zone and the outline of the thrusted wedger are indicated. Gray lines indicate the reflection seismic dataset used for the regional interpretation of the platform carbonates. This map shows the outline of the continuous Nido platform. Isolated carbonates occur also on the Reed Bank and in the Dangerous Grounds. The color code of the legend ranges from very shallow (bright yellow) to deep (blue).

Figure 41: Correlation chart of five wells that penetrated the Tabon limestone offshore SW-Palawan. The tops of foraminiferal assemblage zones are superimposed shown on the lithologs of the wells. The Tabon limestone and the accretionary wedge are highlighted by shaded background and the ages of the formation tops are given in the lagend. The insert map shows the position of the wells on the shelf (see also Figure 36).

Figure 42: Deposition scheme of Tabon limestone. Bars indicate the measured (solid) and Calculated (dashed) deposition times for the limestone. The thickness of the limestones is given for each well. Inset map shows the position of the wells on the shelf.

Figure 43: Distribution of Tabon limestone on the western Palawan shelf. Areas with proven occurences of the limestones are shaded. Onshore outcrops near the city of Quezon are also shaded. Ages are given for the oldest parts of Tabon limestone at different locations

Figure 44: Reflections seismic profile A-A', running across the Palawan-Borneo Trough and the accretionary wedge offshore southern Palawan. In the interpreted section (bottom) the main unconformities are shown. (color code is given in Figure 37). The rifted half-graben structure of the Palawan-Borneo Trough is shown in the central and left part, the thrusted wedge is visible on the right side. The full litholog of the well is given on the right, next to the seismic line. The location of the profile is shown in Figure 36 
Figure 45: Reflection seismic profile C-C', running across the Palawan-Borneo Trough and the accretionary wedge between southern Palawan and Balabac Island. This line illustrates the structure of the thrusted wedge and the two limestone formations, the Nido and the Tabon. The position of the profile is shown in Figure 36. Top: not interpreted seismic; bottom: Line-drawing interpretation with limestones highlighted by bold lines. The reference well Murex-1 was projected from a distance of approximately $15 \mathrm{~km}$ onto the line. The inferred position of the Nido limestone underneath the wedge is indicated by a dashed line due to the strong decrease in seismic resolution underneath the wedge. The rectangle indicates the position of the enlarged section shown in figure 37.

Figure 46: Reflection seismic profile showing the expression of the Tabon limestone. (top - not interpreted; bottom - interpreted; right: lithology of Murex-1 well). The position of the Tabon limestone is highlighted in the interpreted section.

Figure 47: Reflection seismic section across the NW Palawan shelf (top - not interpreted; bottom - interpreted). Position of profile is indicated in Figure 36. The position of the Nido limestone is highlighted by shading. Welltops of two wells are given for correlation. Rift structure and postrift strata are shown. The reef at $\sim 5 \mathrm{~km}$ in an example for isolated carbonate development after the overall cessation of the Nido platform growth.

Figure 48: Part of seismic profile so197-30 located in the Palawan-Borneo trough.Red reflector shows no indication of beeing a stratigraphic unconfirmity. 88

Figure 49: Detail of seismic line BGR84-01, crossing the wedge south of Balabac Island.

The reflecion of the Top Nido Platform is hardly visible underneath the western edge of the wedge (left) and underneath the wedge no clear signal could be received below $~ 3000 \mathrm{~ms}$.

\section{List of tables}

Table 1: Overview of regional names used in this thesis and in international publications.

DoE: Department of energy (www.doe.gov.ph)............................................................. 5

Table 2: Overview of the main interpreted stratigraphic units, showing the characteristic

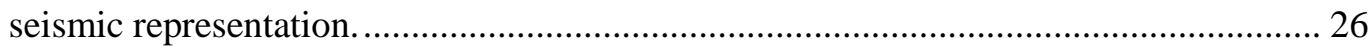

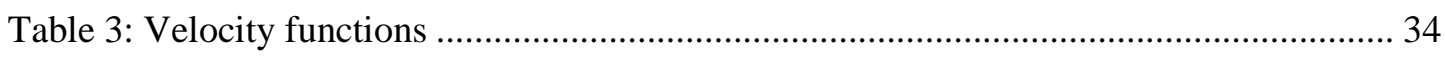

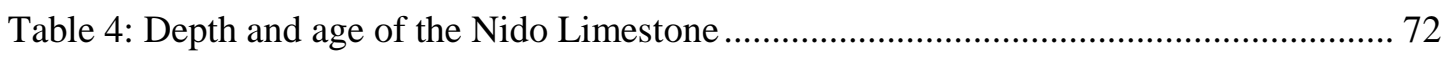

Table 5: Depth and age of the Tabon Limestone................................................................... 72 


\section{Appendix}

The appendix will comprise the following items:

- Structural map of the South China Sea

- $\quad$ List of used seismic surveys

- Seismostratigraphic concepts:

o North Palawan Offshore

o South Palawan Offshore

o Dangerous Grounds

- Well correlation tables

o NW-Palawan shelf

o SW-Palawan shelf

o Reed Bank

o SW-Palawan shelf south - Sulu Sea

o NW-Palawan shelf north - Sulu Sea

- Curriculum vitae 


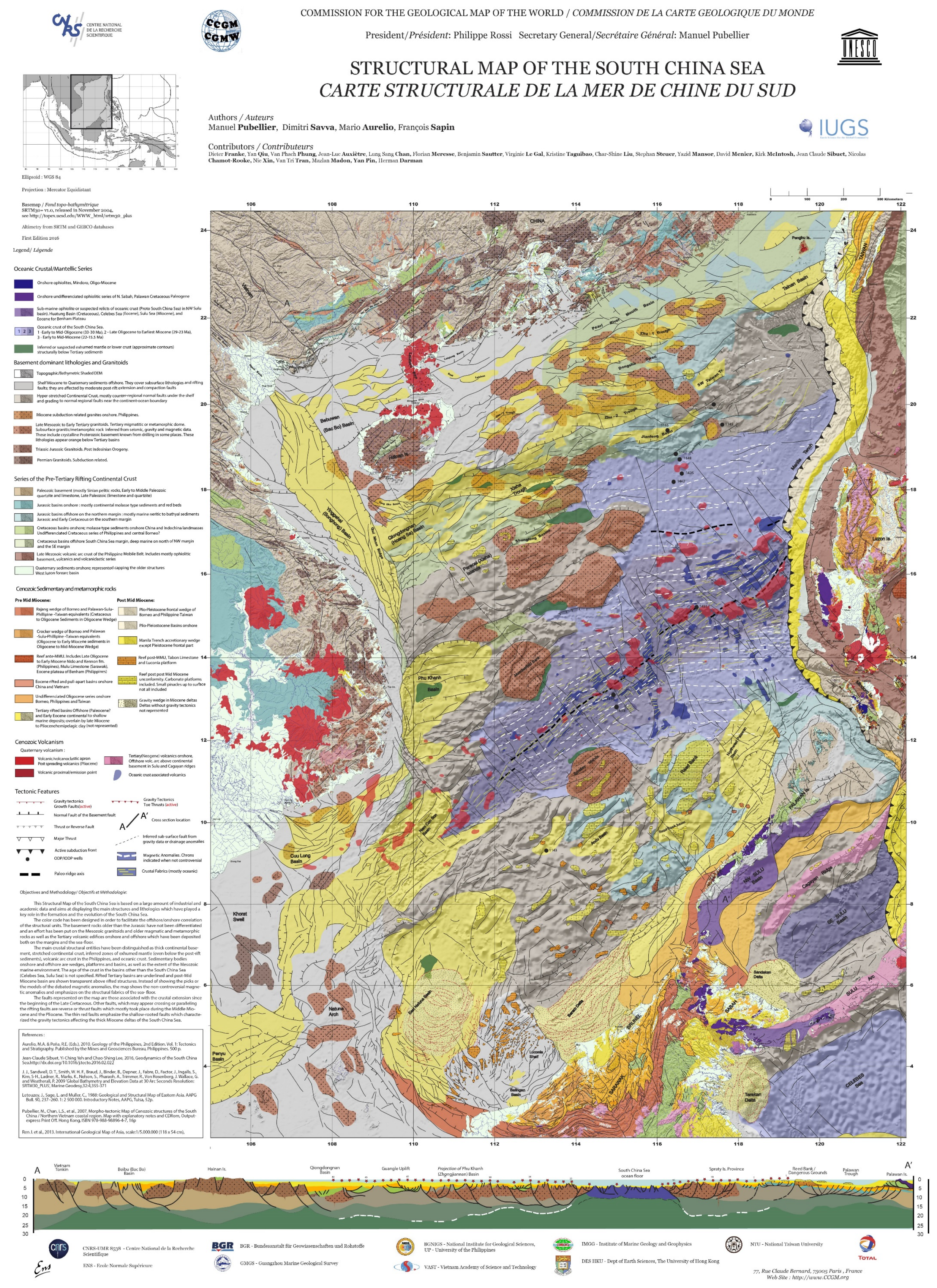


List of used seismic surveys

\begin{tabular}{|l|l|}
\hline Survey & Number of seismic lines \\
\hline BGR08 & 32 \\
\hline BGR84 & 32 \\
\hline BGR86 & 41 \\
\hline Bendix 70 & 25 \\
\hline DPS93 & 16 \\
\hline Hightower 71 & 9 \\
\hline Mobil 71 & 20 \\
\hline Nido 2004 & 1 \\
\hline Palawan 71 & 11 \\
\hline SC6307 & 12 \\
\hline So23 & 37 \\
\hline So27 & 32 \\
\hline So49 & 23 \\
\hline All surveys & 291 \\
\hline
\end{tabular}




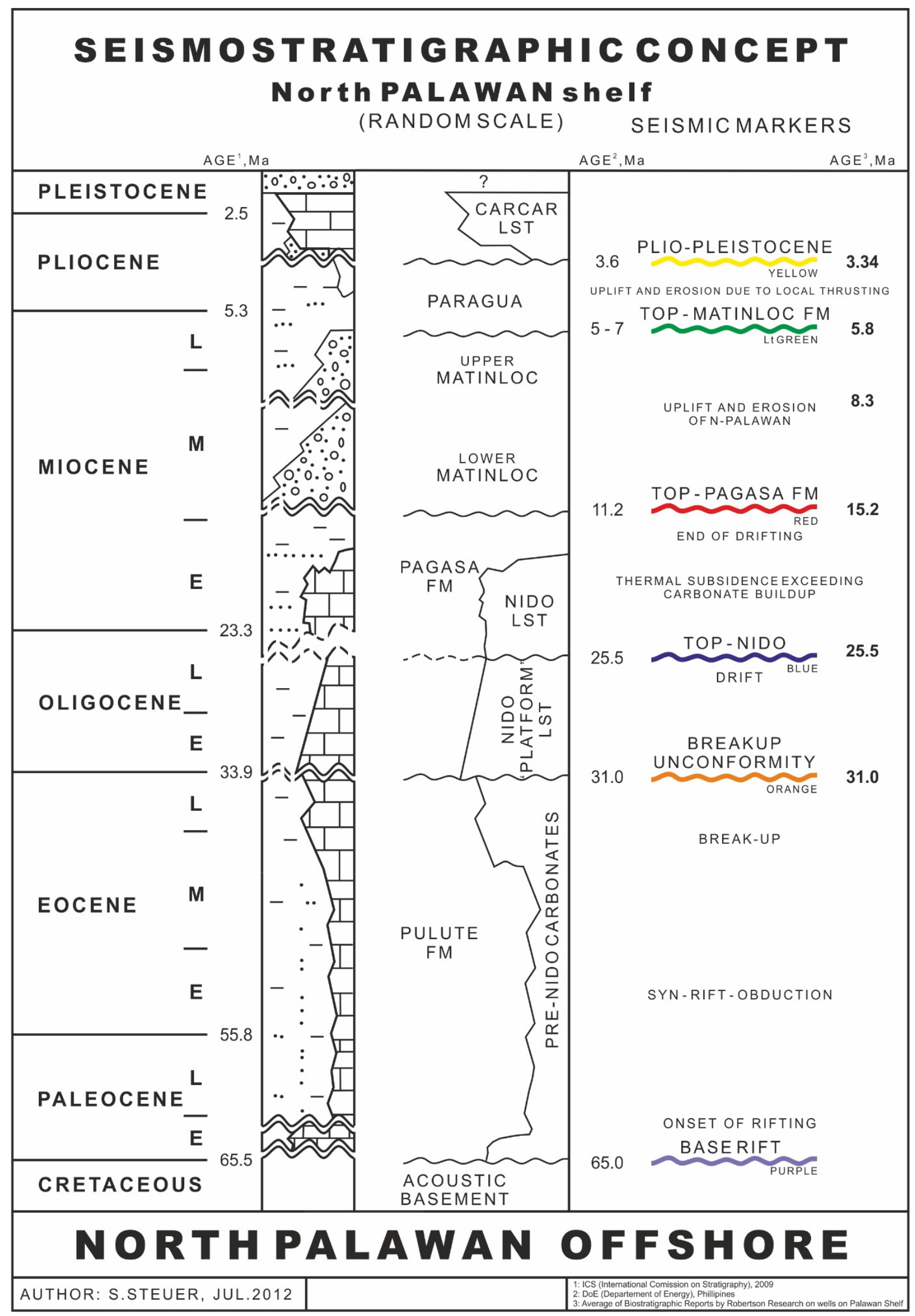




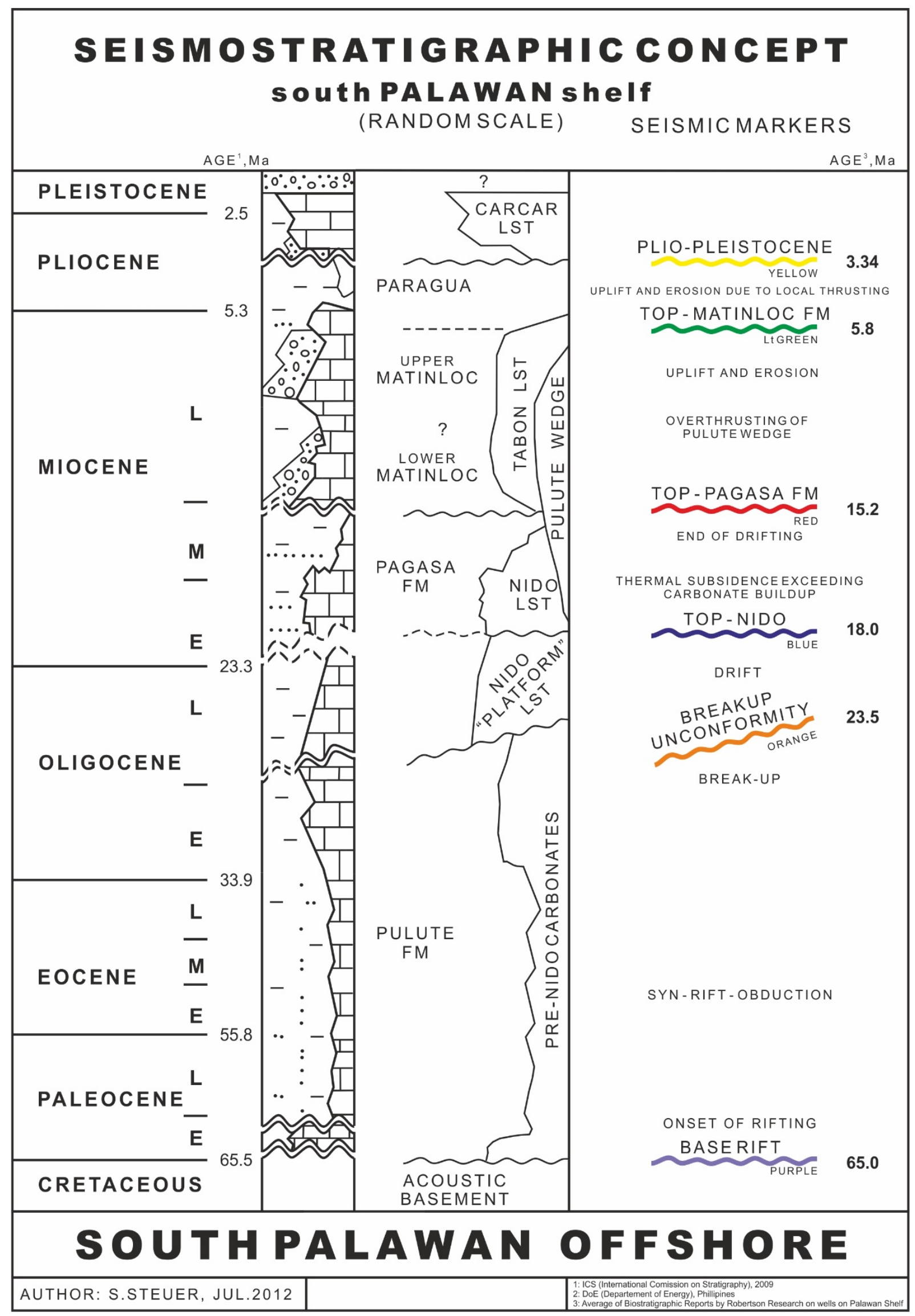




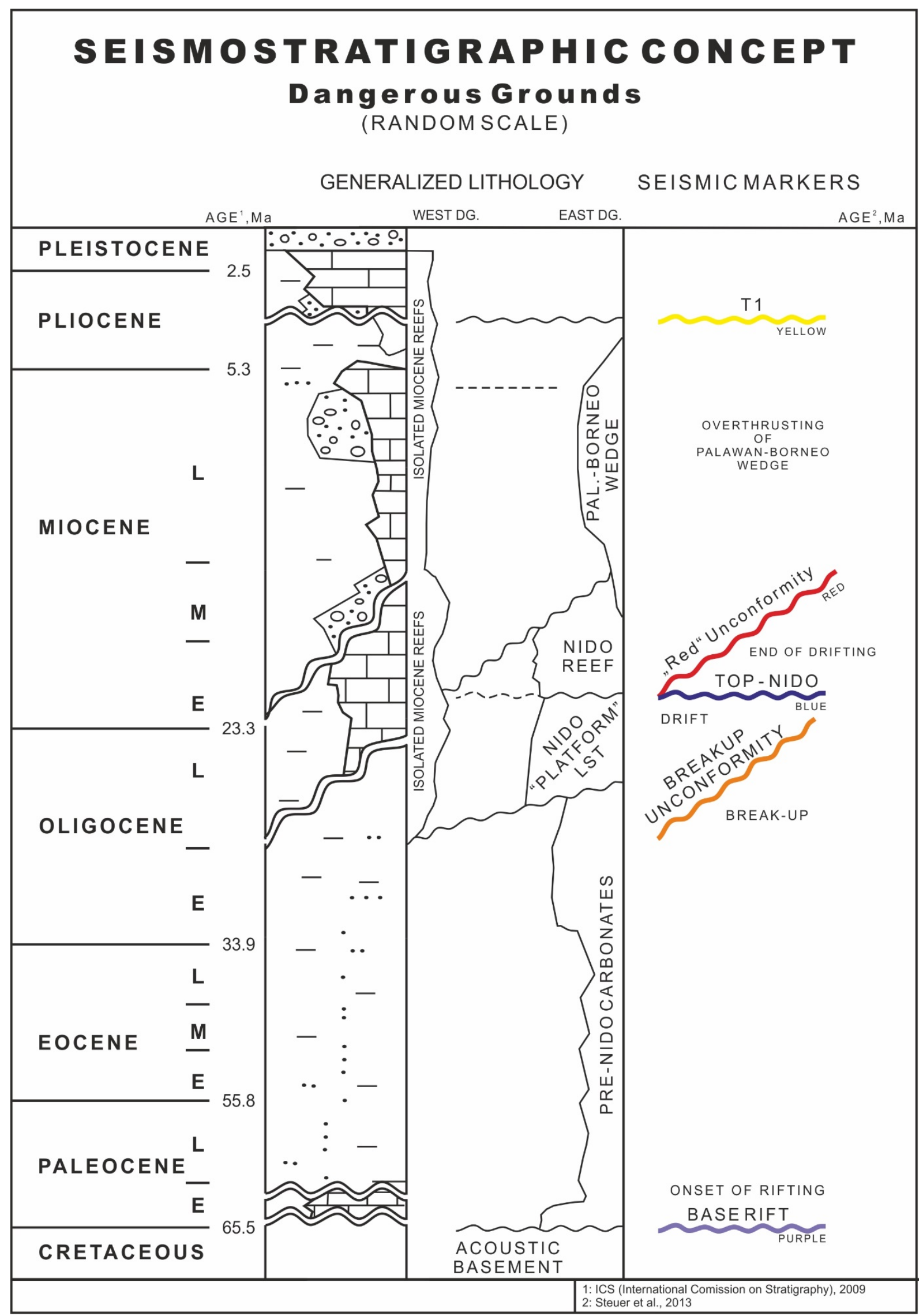




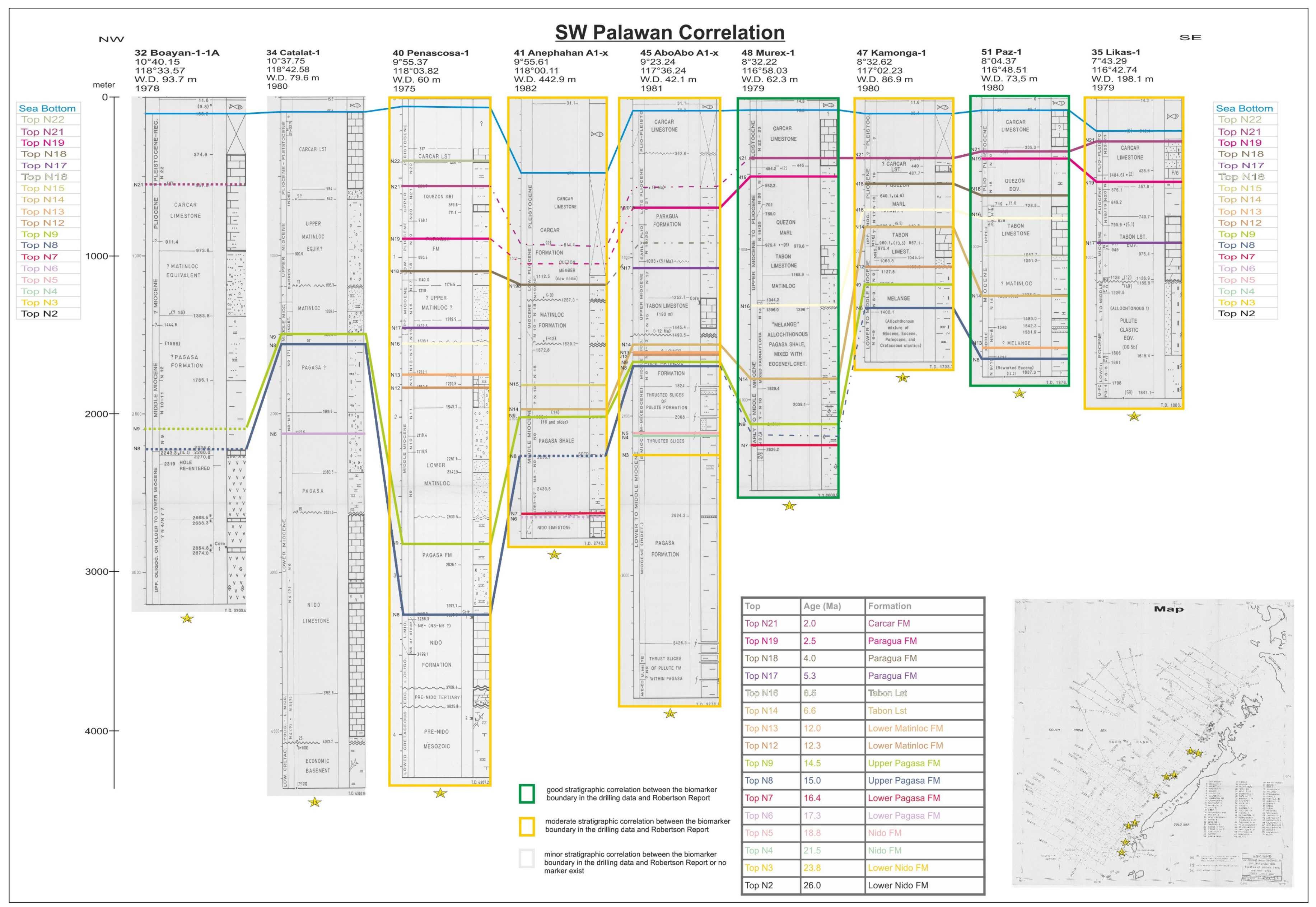




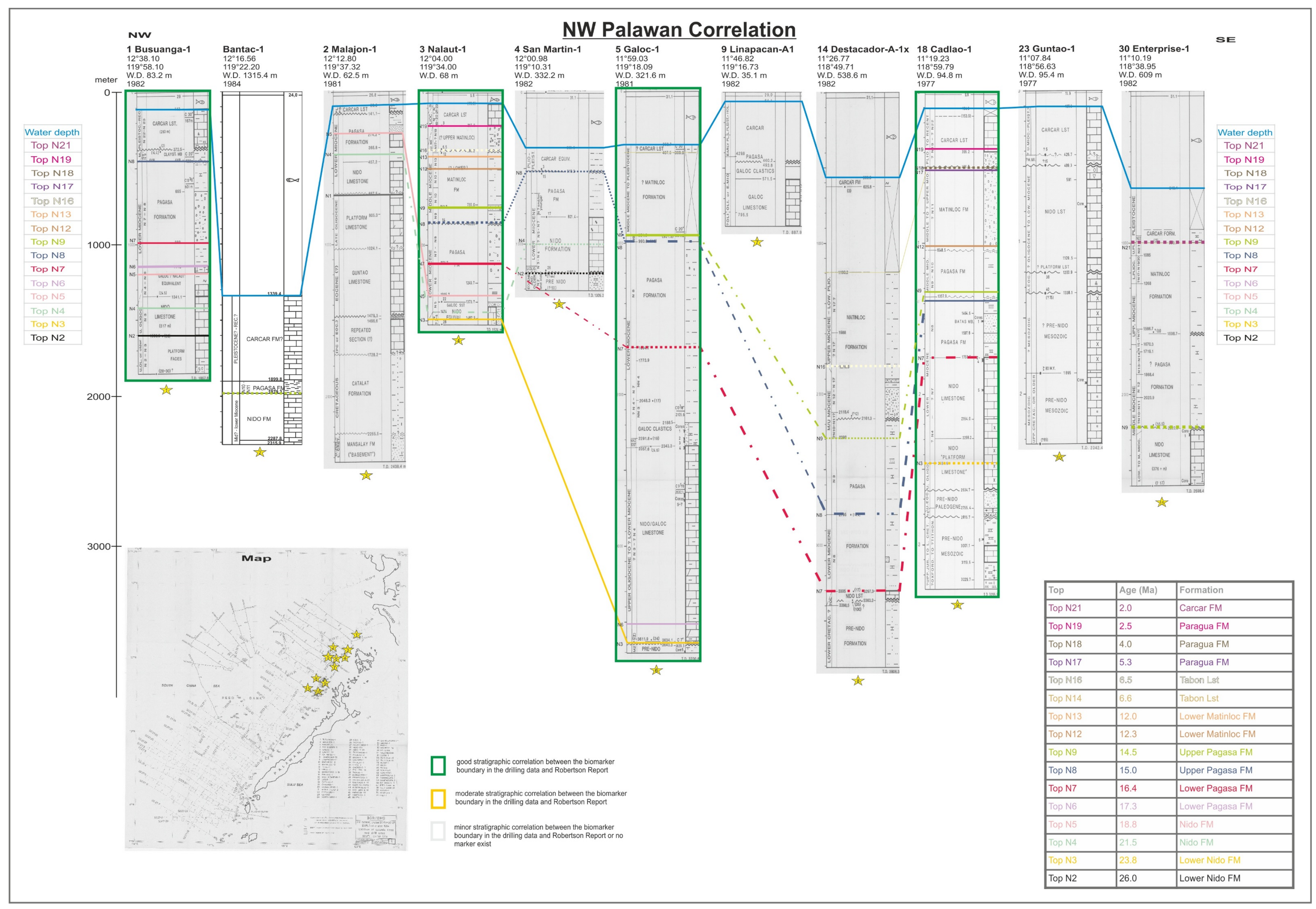




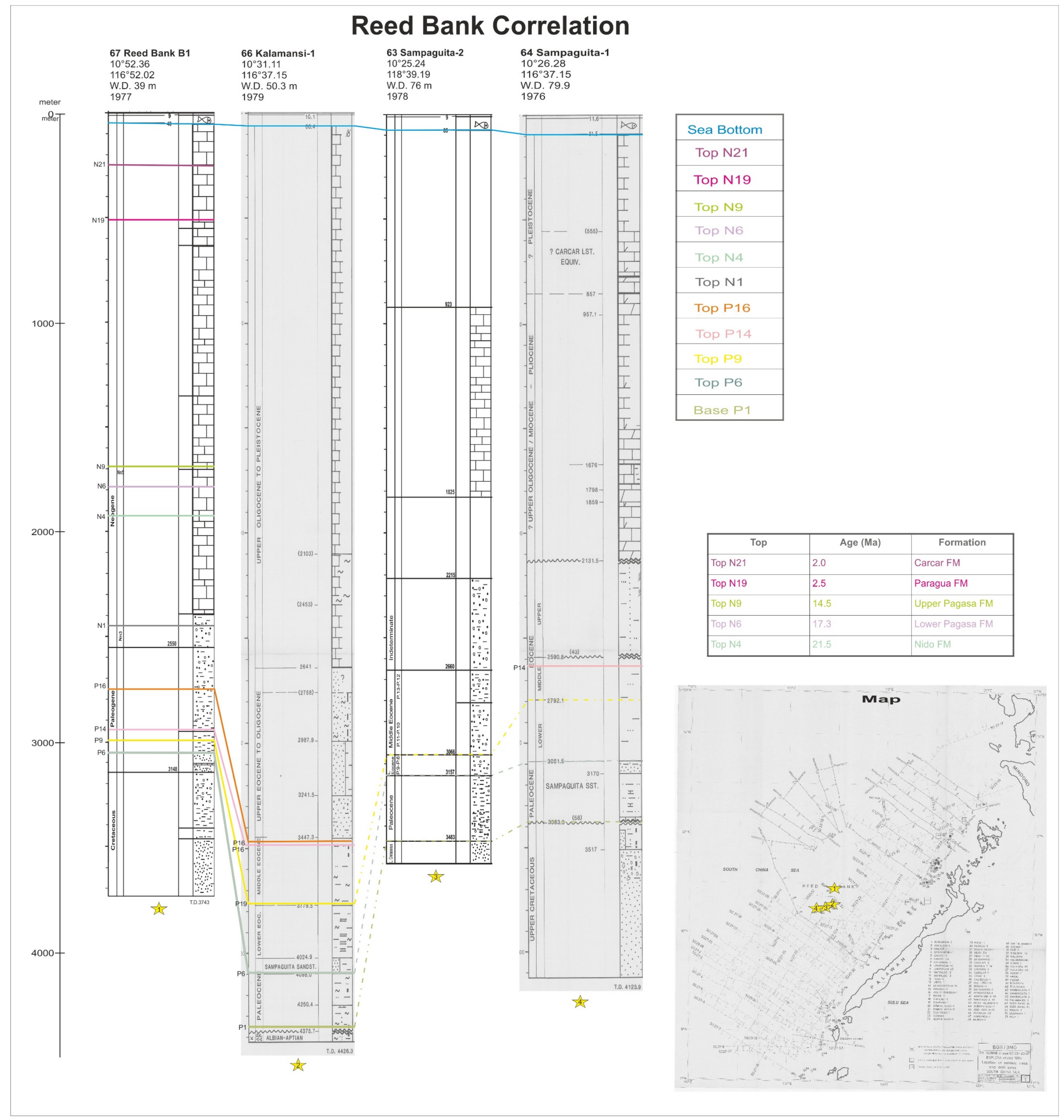




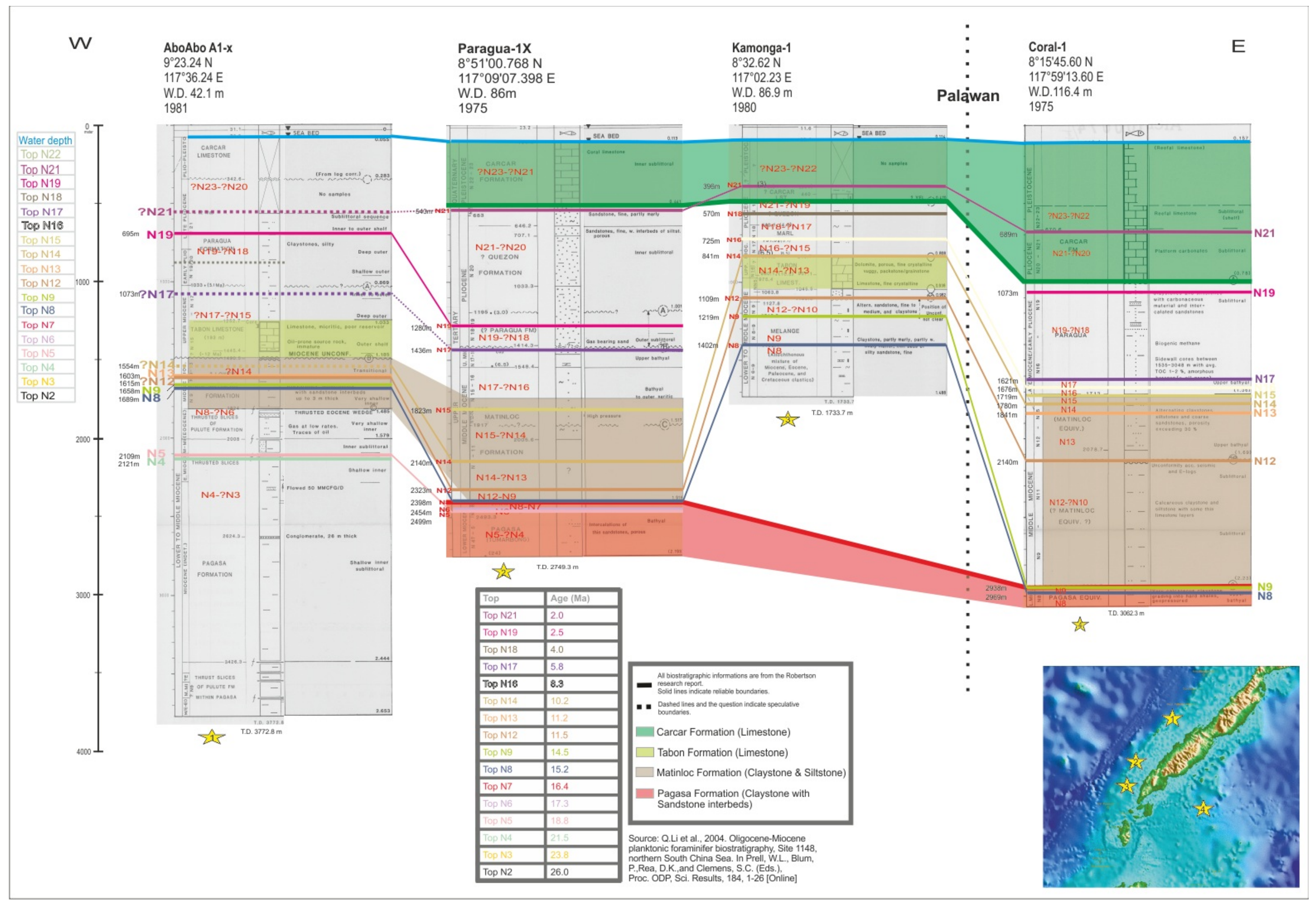




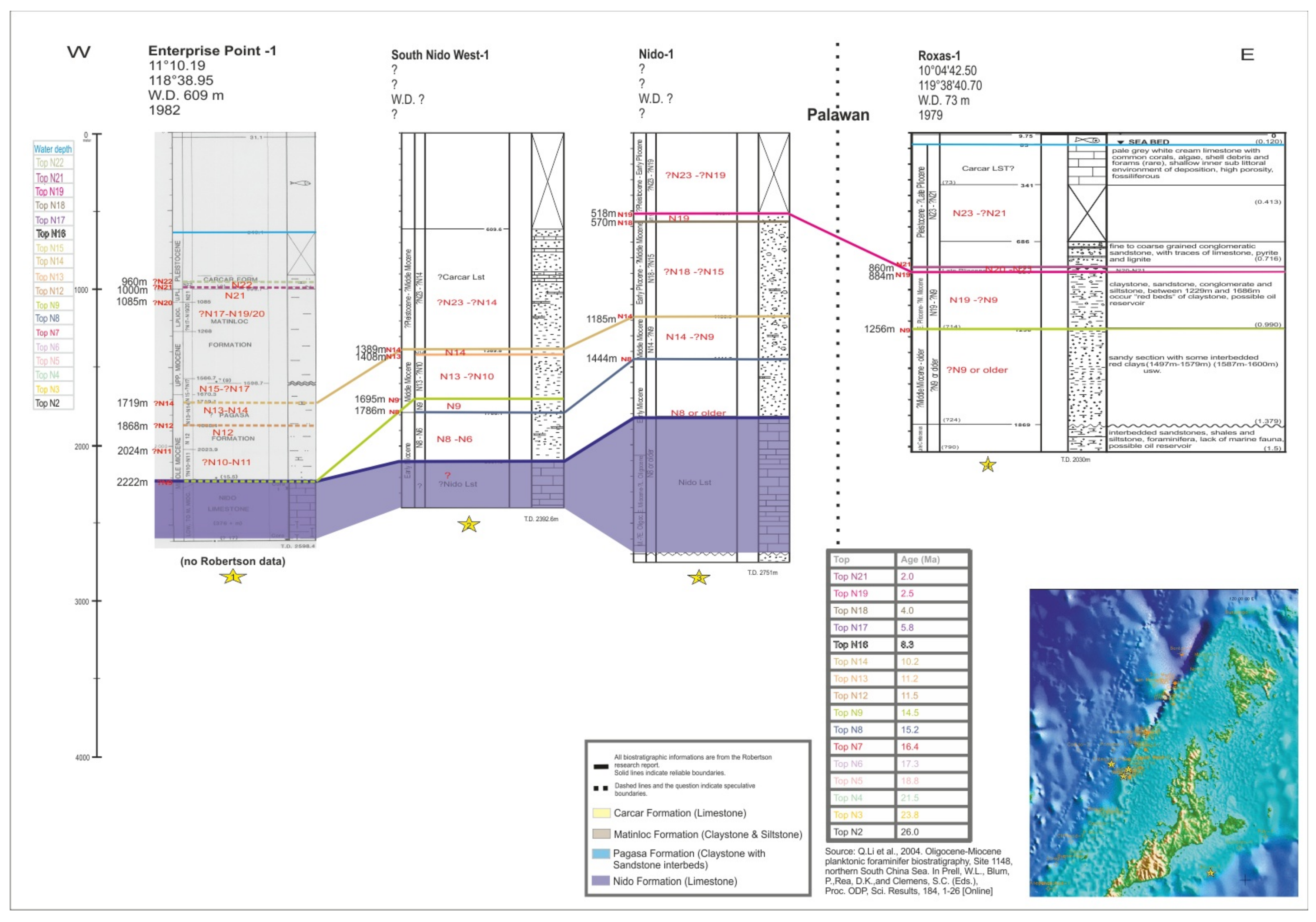




\section{Stephan Steuer}

Freienwalder Straße 13

stephan_steuer@icloud.com

30629 Hannover

+49(0)1709990141

+49(0)51189767887

\section{Geologist (Diploma)}

Specialised in: Seismic interpretation - 3D Modelling - Structural geology - Sedimentology

\section{Work experience:}

Federal Institute for Geosciences and Natural Resources (BGR) - Hannover Department of Subsurface Use, Geological $\mathrm{CO}_{2}$ Storage

\section{Structural geologist / 3D modeller \\ 01/07/2013 - present}

Development of 3D-modells,

Coordination of 3D modelling activities between the state geologic surveys

of Germany

Coordination of cross-border harmonisation of 3D models with neighbouring

countries

3D modelling in the German North Sea sector

Development of structural / lithologic models of geothermal reservoirs

Development of new strategies to communicate 3D models to the public

Ongoing projects:

TUNB (Subsurface potential of the deep underground in northern Germany)

Coordination of 3D modelling activities between the state geologic surveys

of northern Germany, development of a structural 3D model of the german

North Sea, modelling of the lithofacies and lithologic distribution in the german

North Sea

GÜK8 (Revision of the map for geologic subsurface classes for Germany)

Development of a harminised 3D model for base Quarternary and base Tertiary

in SW-Germany

GeoBASIS 3D

Planning and realisation of a high-resolution 3D seismic survey in the German

North Sea

Personal achievements:

Development of a 3D structural and lithological model for a geothermal reservoir

in Lower Saxony

Best presentation award for talk "Vom Wissen und Nicht-Wissen -

Visualisierung von Unsicherheiten in der geologischen Modellbildung"

(To know or not to know - a basic approach to visualise uncertainties

in geological models)

Member of the innovation council of BGR 
Federal Institute for Geosciences and Natural Resources (BGR) - Hannover Department of Economic Geology of Energy Resources, Polar geology

\section{Geologist}

$15 / 02 / 2010-28 / 02 / 2013$

Groupe Recherche Industrie (GRI) South China Sea

Evaluation of the hydrocarbon potential of the South China Sea.

Seismic Interpretation, Well correlation, structural analysis

Regular research visits at Ėcole Normale Supérieure (ENS) in Paris

Regular work stays at TOTAL headquarters in Paris

Personal achievements:

4-weeks field research on Palawan Island, Philippines

$08 / 11 / 2010-04 / 12 / 2010$

4-weeks 3D seismic cruise North Sea

Implementing and testing of mobile marine 3D seismic equipment

09/08/2012 - 06/09/2012

Frequent working visits at Ėcole Normale Supérieure (ENS) in Paris

Frequent collaboration with colleagues from TOTAL in Paris.

\section{Albert - Ludwigs - University Freiburg - Freiburg Department of Geology}

\section{Assistant lecturer}

Lectures and exercises about introduction to geology, structural geology,

endogene geology, interpretation of geologic maps...

Field trips and mapping courses

Supervision of diploma mappings

Research and publication

\section{Albert - Ludwigs - University Freiburg - Freiburg Department of Geology}

\section{Assistant}

$01 / 02 / 2009-30 / 09 / 2009$

Preparation of lecture materials, correction of exams, leading of field trips and mapping courses,...

Personal achievements:

Preparation of a lecture about fracture recognition and interpretation in well logs

Supervision of a mapping course in northern Germany 


\section{Education:}

Albert - Ludwigs - University Freiburg - Freiburg

Department of Geology

Geologist (Diploma/Msc) graduation 11/2008,

$01 / 10 / 2002-21 / 01 / 2009$

Specialized in: Structural geology - Sedimentology -

Modelling (Geology of hydrocarbons) - Geothermal energy

Diploma thesis at Gaz de France PEG (now Engie E\&P) Lingen (Ems)

Personal achievements:

Development of new 3D structural reservoir models for lower Triassic

(Bunter) sandstones and upper Permian (Zechstein) carbonates based upon seismic interpretation and well logs.

Correlation of 13 wells in Lower Saxony, Germany.

Field trips to:

New Zealand, Spain, Norway, Italy, Austria, Switzerland,

Germany... (126 days in total)

Additional lectures in:

Geology of nuclear waste repositories, Volcanology,...

University of applied Sciences - Weingarten

Department of Electro-technic and Computer Sciences

Computer Sciences (FH)

$01 / 04 / 2000-30 / 06 / 2002$

Cancelled in favour of Geology

Spohngymnasium Ravensburg

Grammar school, Graduation: Abitur

01/08/1989 - 25/06/1998 


\section{Internships:}

Gaz de France PEG (now Engie E\&P) - Lingen (Ems) 01/05/2007 - 30/06/2007 Assistance in well planning, data acquisition for a possible gas field in south Germany

Personal achievements:

Deep insights in the preparation and drilling of a wildcat well in the faulted and folded "Molasse" basin.

EADS Dornier GmbH - Friedrichshafen 01/04/2001 - 30/09/2001

Programmer, development of the GIS application Geogrid ${ }^{\circledR}$

\section{(Summer-) Jobs:}

\section{(Summer-) Jobs:}

\section{Ravensburger Freizeit \& Promotion Service}

01/01/2001 - 14.02.2010

Meckenbeuren (weekends and semester breaks)

Product presentation, responsible for stands on fairs

Personal achievements:

Book presentation on Frankfurt book fair.

\section{Forschergruppe Steiber - Freiburg}

01/05/2003-01/11/2007

Museum guide / researcher (weekends and semester breaks)

Exploring and mapping of a medieval silver mine.

Guiding tours trough the mine.

Personal achievements:

Mapping of a new discovered Zink ore deposit.

Creation of a new display in the museum mine.

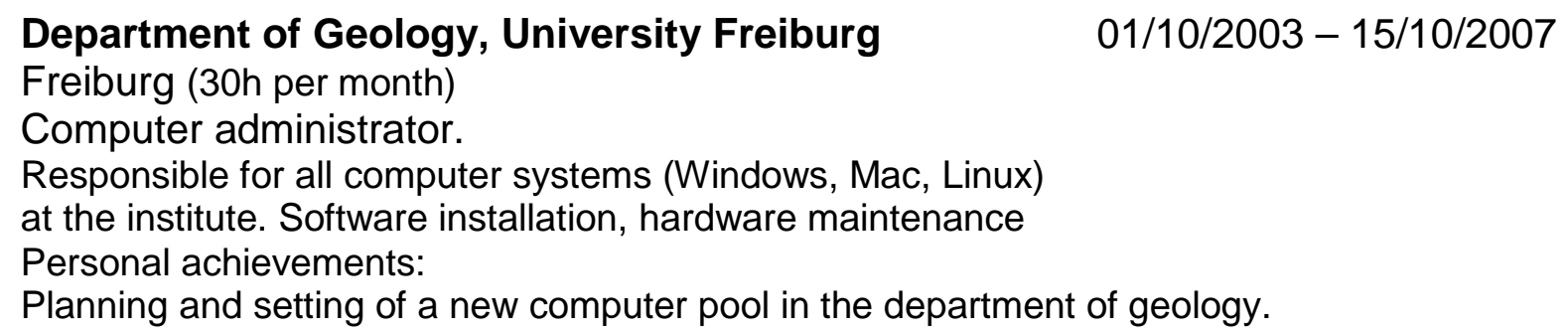

$01 / 10 / 2003-15 / 10 / 2007$

Ravensburger Spieleland - Meckenbeuren

01/05/1999-01/12/1999

Summer job in a theme park (full time)

Personal achievements:

Game show host in the theme park

German army - Sonthofen

Military service (full time)

\section{Personal interests:}

Sports: $\quad$ Running, Climbing, (Beach-)Volleyball, Soccer, Mountainbiking, Rowing.

Mining: $\quad$ Exploring and mapping of old mines in the Black Forest

RC Helicopter flying 


\section{List of publications:}

\section{Main author:}

\section{Paper:}

"Time Constraints on the Evolution of Southern and Central Palawan Island, Philippines from On- and Offshore Correlation of Miocene Limestone Formations"

Journal of Asian Earth Sciences (2013)

"Oligocene-Miocene carbonates and their role for constraining the rifting and collision history of the Dangerous Grounds, South China Sea"

Marine and Petroleum Geology (2014)

Talk, Poster:

"Research Project South China Sea"

Poster at GeoDarmstadt (2010)

"Well Correlation and Seismic of West-Palawan revisited"

Vortrag at GRI Workshop (2011)

"Offshore-onshore correlation across Palawan Island, Philippines"

Poster at EGU (2011)

"The internal structure of the southeastern margin of the South China Sea between Reed Bank and the west Luzon basin"

Poster at AGU fall meeting (2011)

"Time Constraints on the Evolution of Southern and Central Palawan Island, Philippines from On- and Offshore Correlation of Miocene Limestone Formations"

Vortrag at AAPG ICE (2012)

"Carbonates in the Dangerous Grounds - an Overview"

Poster at AGU fall meeting (2012)

"Using Oligocene to Pliocene limestone formations to constrain the collision history of Palawan Island and the Dangerous Grounds at the southeastern margin of the South China Sea" Vortrag at Petroleum Geology and Exploration of Palawan and Surrounding areas (2014)

"Storage potential of a saline aquifer - a case study in the southern German North Sea" Poster at GeoFrankfurt 2014

"Are you sure? - Visualizing geological uncertainties in structural 3D models" Poster at GeoBerlin 2015

“"KISS" visualization of structural uncertainty in 3D models"

Poster at GeoBremen 2017

Vom Wissen und Nicht-Wissen - Darstellung von Unsicherheiten in geologischen 3D Modellen Vortrag at Workshop Simulation in den Geo- und Umweltwissenschaften

"Let's play - The use of Minecraft to communicate the complexity of the subsurface to the public"

Poster at GeoBonn 2018 


\section{Co-author:}

\section{Paper:}

"Seismic evidence of hyper-stretched crust and mantle exhumation offshore Vietnam" Tectonophysics, (2013)

"Seismic stratigraphy and tectonic structure from a composite multi-channel seismic profile across the entire Dangerous Grounds, South China Sea" Tectonophysics (2013)

"The final rifting evolution in the South China Sea"

Marine and Petroleum Geology, (2013)

"Middle to Late Cenozoic tectonic events in south and central Palawan (Philippines) and their implications to the evolution of the south-eastern margin of the South China Sea: Evidence from onshore structural and offshore seismic data"

Marine and Petroleum Geology (2013)

"Different expressions of rifting on the South China Sea margins"

Marine and Petroleum Geology (2014)

"The final rifting evolution in the South China Sea"

Marine and Petroleum Geology (2014)

"Middle to late Cenozoic tectonic events in south and central Palawan (Philippines) and their implications to the evolution of the south-wastern margin to the South China Sea: Evidence from onshore structural and offshore seismic data"

Marine and Petroleum Geology (2014)

"Stress rotation in the suprasalt beneath Hanover (North German Basin) derived from image logs of the deep well Groß Buchholz Gt1"

Zeitschrift der geologischen Gesellschaft (2015)

"To know or not to know - a basic approach to visualise uncertainties in geological models" Jochen Wittmann et al. (eds.), Simulation in den Umwelt- und Geowissenschaften 2018 in Hannover, Shaker Verlag

Posters that are co-authored by me are not listed because of their high quantity

\section{Reports:}

Main author:

Erstellung eines digitalen 3D Lithologiemodells für den Untergrund im Umfeld der Bohrung Horstberg Z1. (2017)

$\underline{\text { Co-author }}$

Fahrtbericht M88/1 (2012)

GSN- Generalisiertes, erweitertes Strukturmodell des zentralen deutschen Nordsee-Sektors (2014)

3D-Lithofaziesmodell des Buntsandstein in der zentralen deutschen Nordsee (2013)

Speicherpotenziale im zentralen deutschen Nordsee-Sektor (2014) 


\section{Additional skills:}

\section{Geologic:}

- Development of velocity models for time - depth migration

- Structural modelling of complex reservoirs

- Well log correlation

- Seismic interpretation

- Clastic sedimentation (Sequence stratigraphy, Microplaeontology,...)

\section{Languages:}

- German: fluent (mother tongue)

- English: fluent (written and spoken)

- Spanish: basic

- French: basic

\section{Software:}

- Petrel (Schlumberger): experienced user

- GeoFrame IESX (Schlumberger): experienced user

- GoCAD (Paradigm): experienced user

- Kingdom Suite (SMT): experienced user

- ArcGIS (Esri): experienced user

- Office (Microsoft/Open Office): experienced user

- Graphic Software (Adobe Illustrator/Photoshop): experienced user

- Operating systems (Windows/OSX/Linux): experienced user / administrator

- SAP advanced user

- Experiences in using other geologic software like PetroMod, GM-Sys, MOVE, FEFlow, Visual Modflow, Ansys.

\section{Other:}

- Business studies (university of applied sciences)

- Driving license for cars up to 7.5 tons 